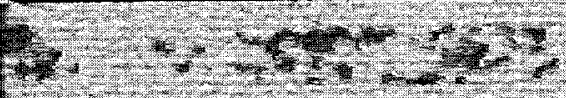

$$
508 / 22 / 01049=-74
$$

\title{
Geothermal Resources in Oregon: Site Data Base and Development Status
}

\author{
by \\ Debra Justus
}
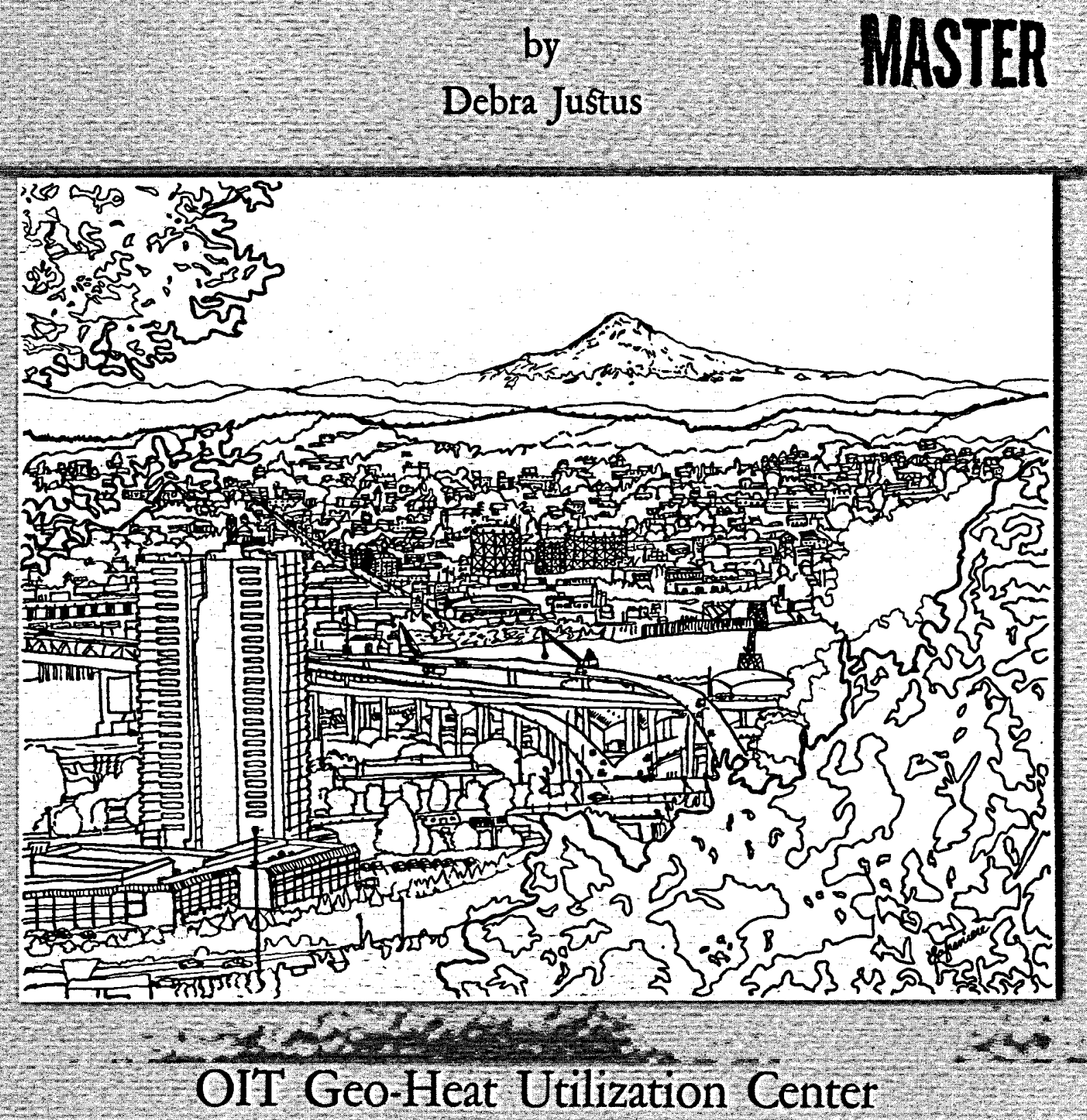

in cooperation with

Oregon Energy Office
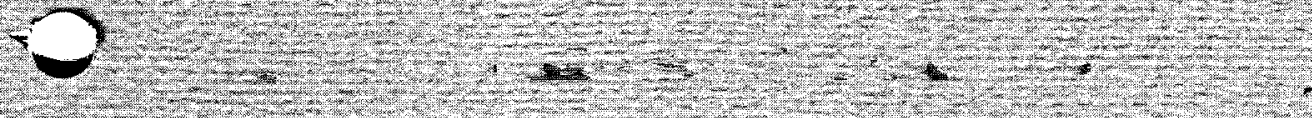

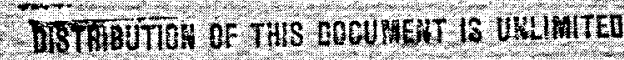

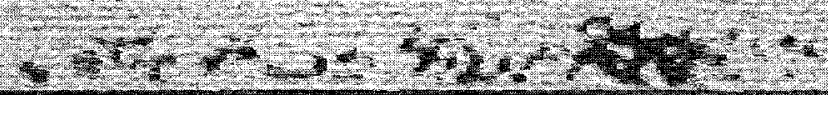




\section{DISCLAIMER}

This report was prepared as an account of work sponsored by an agency of the United States Government. Neither the United States Government nor any agency Thereof, nor any of their employees, makes any warranty, express or implied, or assumes any legal liability or responsibility for the accuracy, completeness, or usefulness of any information, apparatus, product, or process disclosed, or represents that its use would not infringe privately owned rights. Reference herein to any specific commercial product, process, or service by trade name, trademark, manufacturer, or otherwise does not necessarily constitute or imply its endorsement, recommendation, or favoring by the United States Government or any agency thereof. The views and opinions of authors expressed herein do not necessarily state or reflect those of the United States Government or any agency thereof. 


\section{DISCLAIMER}

Portions of this document may be illegible in electronic image products. Images are produced from the best available original document. 
City of Portland with Mt. Hood, a pleistocene volcano, on the horizon sketched from a photo by the Oregon Department of Transportation.

\section{DISCLAIMER}

This report was prepared as an account of work sponsored by the United States Government. Neither the United States nor the United States Department of Energy, nor any of their employees, nor any of their contractors, subcontractors, or their employees, makes any warranty, expressed or implied, or assumes any legal liability or responsibility for the accuracy, completeness or usefulness of any information, apparatus, product or process disclosed, or represents that its use would not infringe privately-owned rights.

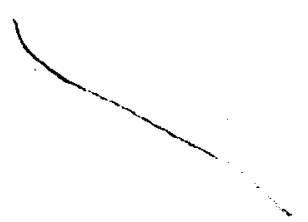




\section{GEOTHERMAL RESOURCES IN OREGON: \\ SITE DATA BASE AND DEVELOPMENT STATUS}

GEO-HEAT UTILIZATION CENTER

Debra L. Justus

Oregon Institute of Technology Klamath Falls, Oregon

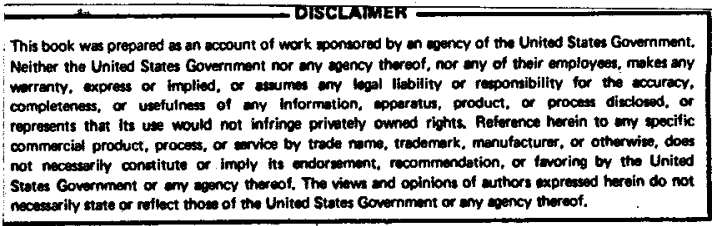

Constitute a imply its endorserment, recommendetion, or tworing of the Unized

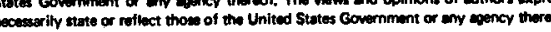


GEOTHERMAL ENERGY IN OREGON:

SITE DATA BASE AND DEVELOPMENT STATUS

Prepared for

U.S. Department of Energy (USDOE)

San Francisco Operations Office Oakland, California.

Contract No. DE-ACO3-79SF1049

by

Debra L. Justus

Geo-Heat Utilization Center

Klamath Falls, Oregon 97601

Apri1, 1979 
Foreword

Among the most critical of problems facing our nation is energy resources. Though there may be minor disagreement about the specifics, magnitude and solutions to these problems there can be no question about their urgency and of the necessity for immediate action. In an effort to in part resolve these questions by accelerating utilization of one of our renewable resources, the U. S. Department of Energy has developed a program of National and Regional Planning and Operations Research of geothermal energy resources.

The OIT Geo-Heat Utilization Center, under contract to USDOE, has evaluated the geothermal energy resource development potential of the six northwest states of Alaska, Idaho, Montana, Oregon, Washington, and Wyoming. Our goal has been to summarize for this region on a site-specific basis the various factors affecting development including resource data base, geological description, reservoir characteristics, environmental character, lease and development status, institutional factors, economics, population and market, and finally potential for development. This report summarizes the known data base for the state of Oregon.

As so little site-specific geothermal resource data is available this then represents a progress report in a young but rapidly developing field of knowledge. The continuation of this project now underway is attempting to complete this core of site information and identify data on new significant sites in Oregon, provide accurate information and recommendations to policy and decision-makers, and ultimately to assist in evolving more effective regional and national geothermal energy programs.

R. P. Koeppen

June, 1979 


\section{PREFACE}

As a consequence of the energy crisis of the early seventies, the United States has embarked on an aggressive program to develop its indigenous energy resources. Geothermal energy is one form considered to have significant potential, particularly in the western states. To encourage geothermal development, Congress adopted the Federal Energy Research Development and Demonstration Act (PL 93-40) in 1974 and mandated federal geothermal programs for resource assessment, planning and system development. A goal of 20,000 to $30,000 \mathrm{MWe}$ from geothermal resources by 1985 was established.

To facilitate geothermal development as mandated by these and other Federal policies, the Northwest Regional Planning Support for the Development of Geothermal Energy Research Project, of which this study is a part, was initiated in 1977. The project objective was to compile an inventory of geothermal resources and construct timeline scenarios which outline steps necessary for resource utilization.

This document examines the geothermal energy development potential in Oregon. The data base and scenarios will serve as tools for local, state and federal planners and policy makers as well as private developers. To be effective the data base should be updated as new information, particularly about reservoir characteristics, becomes available. Further planning studies should concentrate on market potential analysis and ways to generate public awareness and stimulate potential end-users.

Considerable public interest was demonstrated during this investigation, and this report should help to increase public awareness of the potential of local energy resource development. 


\section{ACKNOWLEDGMENTS}

In addition to published materials, much of the information contained in this report was gathered during personal interviews and field investigations with numerous public agencies, private companies and individuals. This assistance is greatly appreciated for without their valuable insights the scope of this report would have been severely limited.

Among those deserving special mention are: Don Hull and the DOGAMI staff, Rich Huggins, John Geyer, Al Prigge, Majorie Waggoner, John and Charlotte Hook, Portland General Electric Co., Chuck Wassinger and Jack McNamara.

The Oregon Department of Energy staff has contributed in numerous ways to the realization of this document. Particular mention is due William Sanderson, Tom Bryson, Michael Grainey and Kathy Peters.

The guidance and policy direction provided by Don Karr, RobertKoeppen, Walter Pollock and David Philbrick has been of vital importance and is gratefully acknowledged. Staff of the Geo-Heat Center also deserve special recognition for their assistance in training the field team and their unrelenting patience in responding to questions.

The support and guidance from my counterparts has been of tremendous benefit and constitutes an integral part of this project. My thanks to Gordon Bloomquist, Keith Brown, Rick James, David McClain and Don Markle.

Special thanks to Tom Bryson for the quality maps contained in this report. 
TABLE OF CONTENTS

Page

FOREWORD ........................... 2

PREFACE $\ldots \ldots \ldots \ldots \ldots \ldots \ldots$

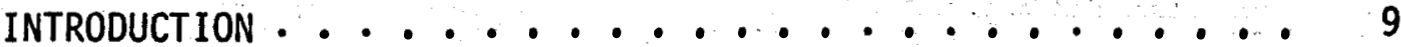

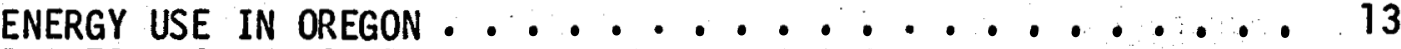

PACIF IC NORTHWEST ELECTRIC UTILITY SYSTEMS:

AN OVERVIEW - M. W. GRAINEY ......... 15

I. BASIN AND RANGE GEOTHERMAL PLANNING REGION

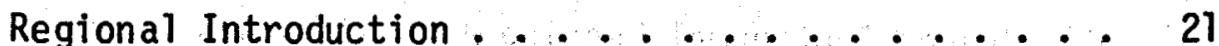

Klamath Fal is KGRA .............. 23

Lakeview KGRA . . . . . . . . . . . . . 55

Summer Lake KGRA . . . . . . . . . . . 77

Crump Springs KGRA $\ldots \ldots \cdot \ldots \cdot \cdots 97$

Alvord Valley KGRA ............... 117

II. HIGH LAVA PLAINS GEOTHERMAL PLANNING REGION

Regional Introduction ............... 145

Newberry Crater KGRA . . . . . . . . . . . 147

Burns Butte KGRA .............. 165

Brothers Fault Zone . . . . . . . . . . 183

III. WESTERN SNAKE RIVER PLAIN GEOTHERMAL PLANNING REGION

Regional Introduction ............. 189

Vale KGRA................. 191

IV. NORTHEASTERN OREGON GEOTHERMAL PLANNING REGION

Regional Introduction . . . . . . . . 217

La Grande PGRA ............. 221

V. CASCADE MOUNTAINS GEOTHERMAL PLANNING REGION

Regional Introduction . . . . . . . . . 241

Mt. Hood KGRA ................ . . 245

Western Cascades Introduction . . . . . . . 267

Carey Hot Springs KGRA. . . ......... 271

Breitenbush Hot Springs KGRA . . . . . . . 291

Belknap-Foley Hot Springs KGRA ........ 319

Mc Credie Hot Springs KGRA .......... 341 
Page

VI. LEGAL AND INSTITUTIONAL FACTORS $\ldots \ldots \ldots 363$

VII. $\quad$ SUMMARY $\ldots \ldots \ldots \ldots \ldots \ldots$

VIII. SELECTED REFERENCES $\ldots \ldots \ldots \ldots$

IX. APPENDICES

A. Existing Uses of Geothermal Energy in Oregon . . 383

B. Selected Industrial Energy Consumption Rates ... 384

C. Oregon Geothermal Leasing Activity ....... 385

D. Oregon Geothermal Heating District Legislation.. 389

E. Oregon Geothermal Resources Act ........ 401

F. Malheur County Geothermal Ordinance ...... 405

G. Leasing Process on Federal Land ....... 437 


\section{LIST OF MAPS}

Figure

$\underline{\text { Page }}$

1 Oregon Geothermal Resources ............ 10

2 Basin and Range Geothermal Planning Region ......... 20

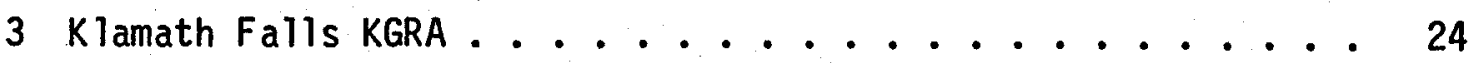

4 Lakeview KGRA ............... . . 56

5 Summer Lake KGRA . . . . . . . . . . 78

6 Crump Geyser KGRA ..................... 98

7 Alvord KGRA ............................ 118

8 Newberry Crater KGRA ............... 148

9 Brothers Fault Zone .............. 182

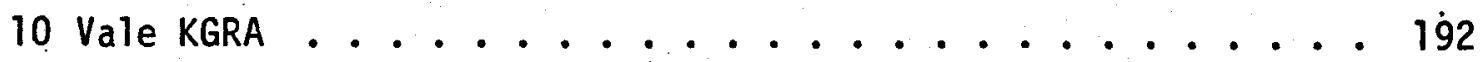

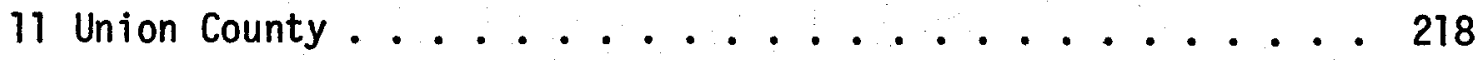

12 Baker County . . . . . . . . . . . . 219

13 Cascades Geothermal Planning Region .......... 240

14 Mt. Hood KGRA ...................... 244

15 Carey/Austin KGRA ...................... 270

16 Breitenbush KGRA ................. 290

17 Belknap/Foley KGRA . . . . . . . . . . . . 318

18 McCredie KGRA . . . . . . . . . . . . . 340 



\section{INTRUDUCTION}

Geothermal energy is natural heat beneath the earth's surface, the same energy that creates geysers, volcanos and hot springs. To some, it is a mysterious phenomenon - an exotic energy source which may in the distant future contribute to the energy supply. But geothermal energy can be effective and cost-competitive with traditional fuels in today's market. And, Oregon has both areas of proven geothermal potential as well as areas which appear to hold potentially valuable geothermal resources.

This natural heat has been used for space heating in Oregon since the turn of the century. It is often stated that geothermal development is in its infancy. But in Klamath Falls where homes have been heated with geothermal energy for more than 45 years, hot water is old news.

The widespread use of hot water for space heating in Klamath Falls has in part made Oregon the nation's leader in direct use applications of geothermal energy. Uses range from the de-icing of highway pavements and milk pasteurization to space heating of commercial buildings and greenhouses. The peak utilization of geothermal energy is estimated at 60 megawatts thermal $\left(M W_{t}\right)$ in Klamath Falls. The overall contribution of geothermal energy to Oregon's total energy supply is relatively small, but is growing steadily.

The potential for additional and expanded use of geothermal resources in Oregon is substantial. Geothermal energy reserves are generally situated in areas of geologically recent volcanic activity. Numerous areas of young volcanic rocks with geothermal potential have been identified in Oregon. The presence of more than 170 hot springs, situated primarily from the Cascades east across the state, provides further evidence of likely thermal reserves at depth. Among the physiographic provinces of Oreon, those having high potential are the Cascade Mountains, Basin and Range, High Lava Plains and Uwyhee Upland.

The U.S. Geological Survey has classified 13 areas of the state, comprising 431,936 acres, as Known Geothermal Resource Areas (KGRA), and 10 broad oreas as prospectively valuable for geothermal resources (PGRA). The KGRA designation requires that federal land within the area be leased on a competitive basis. Leasing on federal land totals 240,247 acres for both competifive and non-competitive leases. Leases on state-owned land comprise 8,294 acres. Private land leases are difficult to confirm but have been estimated at 180,000 acres. Leasing activity has been summarized in Appendix C. Figure 1 is a location map of Oregon's Known and Potential Geotherma1 Resource Areas (KGRAs and PGRAs). 


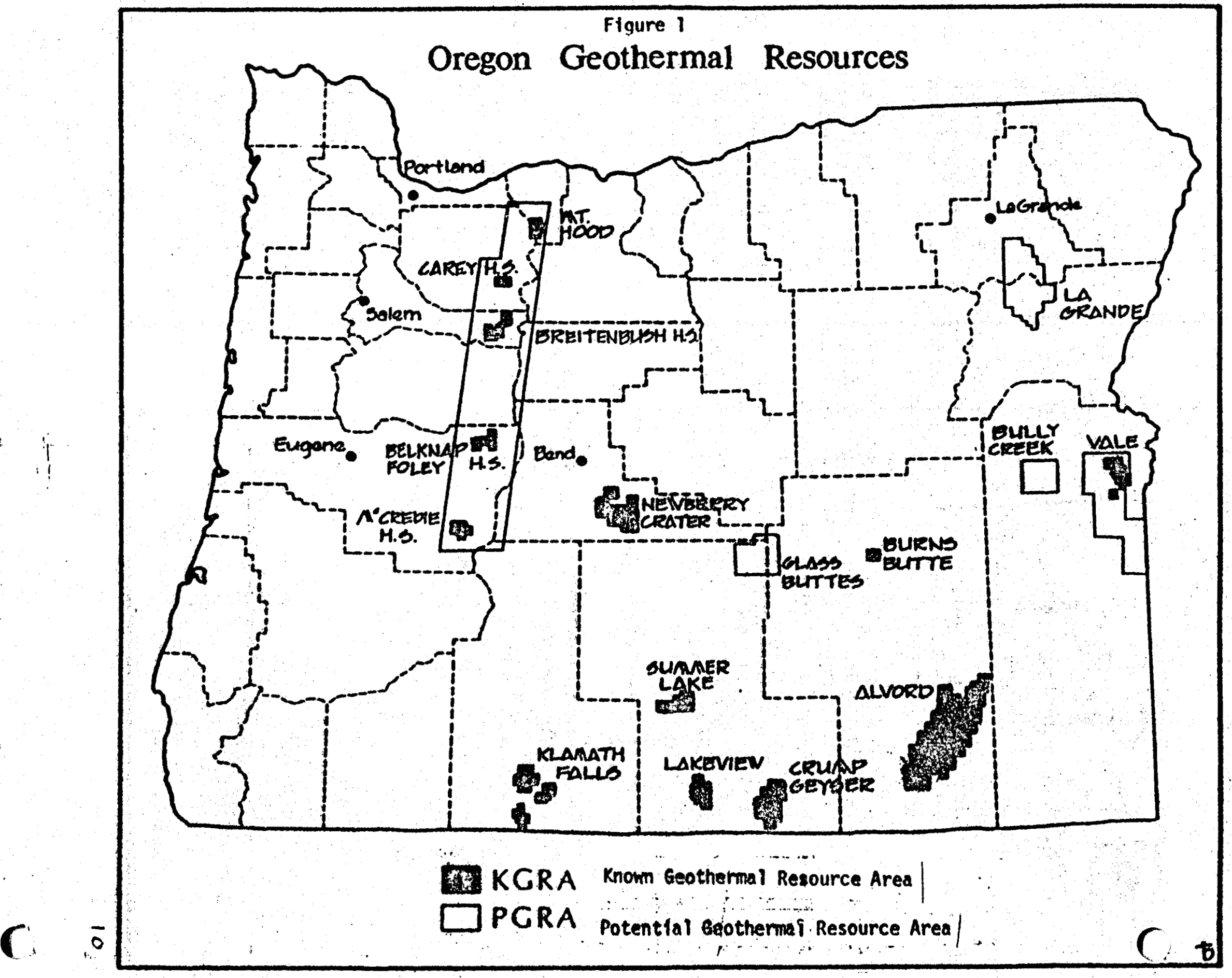


In comparison with other Pacific Northwest states, a substantial amount of geothermal development has already taken place in Oregon. Yet there is considerable untapped geothermal energy potential in the state for both direct use applications and electric generation. Potential non-electric uses range from integrated facilities which use thermal fluids in a cascaded system to industrial processing and district heating systems. Current uses of geothermal energy in Oregon are listed in Appendix A.

The potential for geothermal electrical production from steam or high temperature hot water reservoirs is not well understood or documented. To date, no known resources of sufficient quality for electrical generation have been discovered in Oregon. It is probable that electric power generation will eventually be realized from Oregon's geothermal reserves, but resource assessment must first confirm the existence of a suitable reservoir. Development will then be contingent upon mitigation of environmental and other concerns.

Based on conservative estimates by the U.S. Geological Survey (U.S.G.S.) the total electrical potential in known resource areas in Oregon is 1,640 MWe for 30 years. The estimated potential of resources suited for non-electric uses is 23,100 MWt for 30 years. These figures are minimum estimates based on identified areas and will probably increase significantly as other reservoirs are discovered. Nevertheless, from what is currently known about Oregon's geothermal resources, direct use applications have the greatest immediate potential for development and commercialization.

The following report presents an inventory of resources based on available information and to a lesser extent on field investigations. Potential for utilization and the legal and institutional environment in which development is likely to occur were also considered. Sites selected for this investigation include the 13 identified KGRAs, one PGRA which was chosen because of substantial local interest expressed in favor of development, and one major geologic fault zone which shows indications of high potential. By no means do these sites represent a comprehensive survey of Oregon's geothermal resources. Within the limited duration of this project, these sites were selected because more information was available on the nature of the resource and they offer the most favorable conditions for near term development.

Specific sites are presented within a regional framework. Three planning regions correspond to physiographic provinces in which the sites share similiar physical, environmental, cultural, and economic characteristics. Two planning regions contain only one site each and are less extensive than the physiographic zones. 
Each chapter is introduced by a regional overview of the physical setting followed by subchapters containing a narrative summary statement of the specific resource location and characteristics, existing utilization and potential end-uses for future development. Detailed site information in the form of data sheets follows each narrative. In general, the data sheets present information relevant to the specific sites, but the narratives discuss potential of a broader area and are not restricted to KGRA boundaries.

In most cases, data presented in ths report are current as of November 1978. 


\section{ENERGY USE IN OREGON}

The development of geothermal resources in Oregon depends to a large degree on the overall energy picture. As conventional fuels escalate in cost and availability declines, the attractiveness of geothermal energy development will increase.

Traditionally, electricity has played a major role in meeting energy demand in the Pacific Northwest. The availability of relatively inexpensive electricity from the region's hydro power base has lead to widespread use of electricity for applications such as space heating. As described in the following paper by M. W. Grainey, the electric utility system in the Northwest has been undergoing considerable change since 1973. As the price of electricity goes up and the availability decreases, the situation improves for geothermal and other alternative energy forms to replace portions of the electric load.

This is particularly important for end-uses, such as space and water heating and industrial processing whose thermal requirements allow for efficient use of geothermal fluids, thereby allowing the electric load to meet demands of other uses which require the "higher" quality energy from electricity.

The Oregon Department of Energy has projected that total energy consumption in the state will increase at an average annual rate of 2.4 percent auring the next twenty years. The major impact of geothermal development during this time will be in the residential, commercial and industrial sectors. Those sectors account for about 75 percent of Oregon's projected energy consumption in 1980. Geothermal resource development can most readily effect the near-term energy picture in the areas of residential and commercial space and watger heating, and industrial processing. As illustrated in the following chart, space and water heating account for 65 percent of residential energy use.

These types of energy requirements can easily be fulfilled by geothermal resources when they are available. As the Pacific Northwest energy picture becomes less focused on electricity, fuel switching will become more common and in areas with geothermal potential, development may be enhanced. 


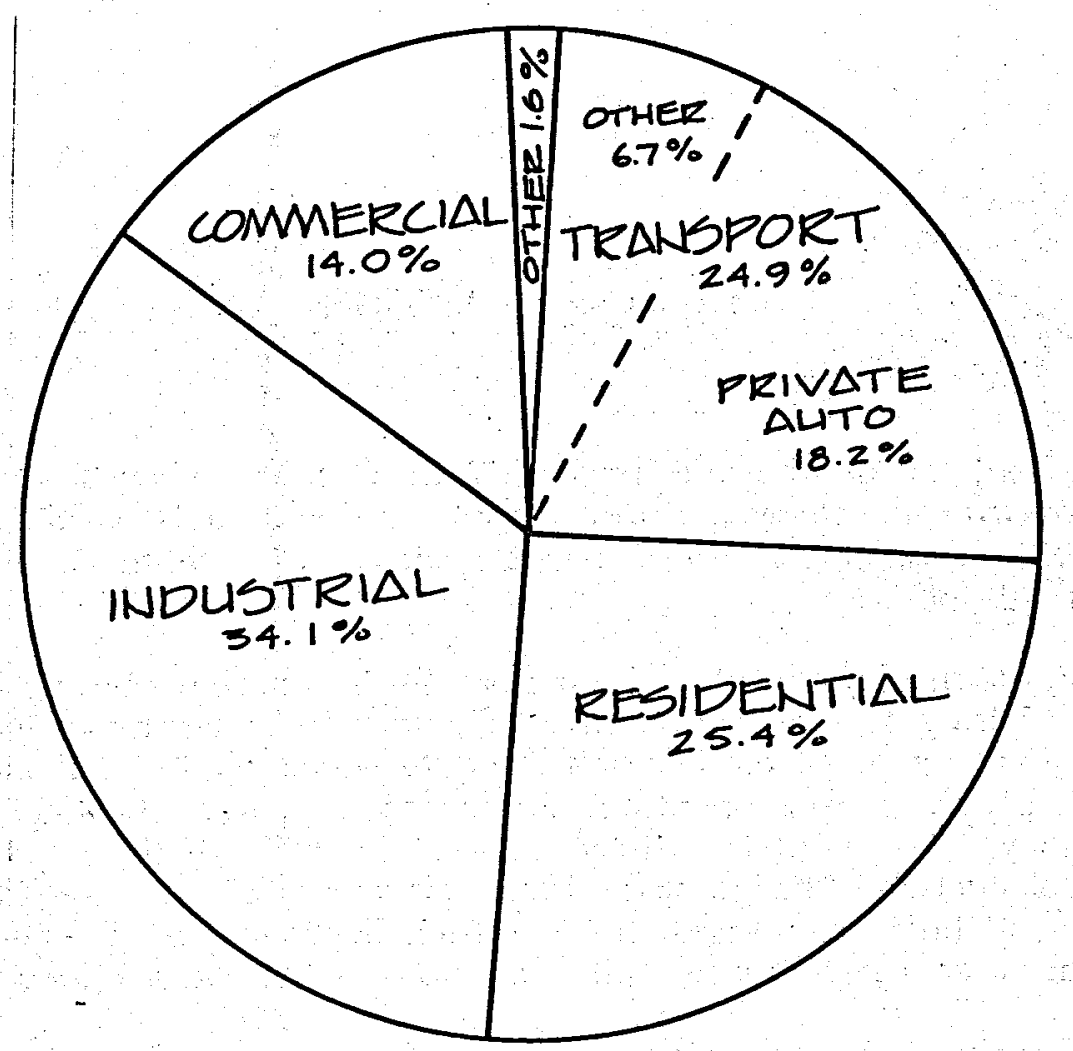

DIRECT ENERG LSE BY SECTOR - 1980

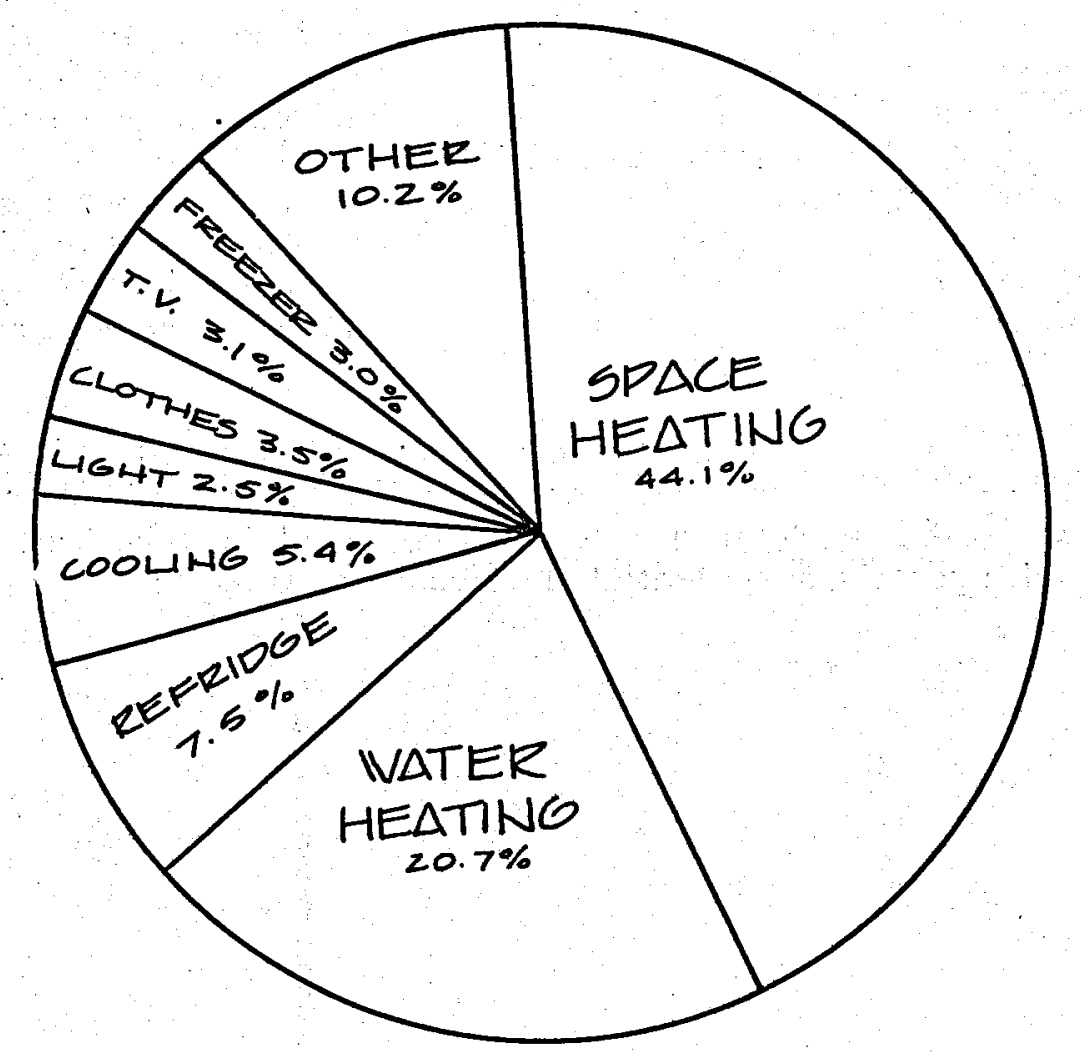

RESIDENTIAL DIRECT ENERGY LSE SOURCE: OKECON DEPT. OF ENERGY 


\title{
THE PACIFIC NORTHWEST ELECTRIC UTILITY SYSTEMS AN OVERVIEW
}

\author{
MICHAEL W. GRAINEY
}

The Pacific Northwest is a region which has many unique features which have contributed to the formation of an unusual electric system. These features also make the use of geothermal energy more readily adaptable and feasible for certain uses in the Pacific Northwest than in any other region in the country.

The region traditionally has been self-sufficient with respect to electric energy. For nearly 40 years the region's electricity has been derived almost exclusively from hydrogeneration. Only in the past decade have the region's utilities turned to the development of thermal power plants (coal or nuclear) for baseload electric generating capacity. The region uses no oil or natural gas for baseload electric power plants, perhaps the only region in the country able to make that claim.

Because hydro power has traditionally been inexpensive and readily available, the region has relied on electricity more heavily than have other regions. For example, per capita use of electricity is nearly double the nationwide average, and electric space heating in the region is used by four times as many residences as the nationwide average.

The Bonneville Power Administration has been particularly dominant in the development of hydroelectric power in the region. BPA is the marketing agency for the federal dams built by the U.S. Bureau of Reclamation and the U.S. Army Corps of Engineers. Dams which comprise the Bonneville system produce 55 percent of the electric power generated in the region and 65 percent of the region's hydroelectric resources.

In addition to providing a substantial amount of the region's electricity, BPA has constructed a highly sophisticated transmission line system linking the entire region. BPA transmits its own power over these lines as well as electricity generated by the region's utilities. The BPA transmission grid has become the backbone for a highly-coordinated regional electrical system. BPA's computer center helps the region's utilities to operate their plants in a coordinated manner to optimize efficient and reliable service and to minimize costs. A Coordination Agreement omong the region's utilities outlines goals and procedures for cooperation. 
BPA traditionally has marketed the power from its dams to all potential users in the region first and if surplus power exists, outside the region as well. In marketing power inside the region, BPA has sold power under the BPA Project Act to preference customers first, namely publicly-owned utilities, and then to investor-owned utilities and direct service industries. Under the provisions of the Northwest Preference Power Act, all users in the Pacific Northwest, whether or not publicly-owned systems, have first access to BPA power over competing claims, whether from publicly-owned utilities or not, outside the region. Before 1973, BPA had sufficient resources to meet all requests for power within the region and to make significant sales outside the region. Events since 1973 have changed this picture, however, and in the process have made the utilization of geothermal resources more desirable from an economic point of view.

In 1973 BPA discontinued the sale of firm power to investor-owned utilities as a series of contracts with those utilities which expired at that time were not renewed. (The contracts of the direct service industries which had not yet expired continued to be honored by BPA.) The reason for this action was that BPA's projected load forecasts indicated that the agency could not provide power to the investor-owned utilities on a firm basis and still meet its statutory commitments to serve publicly-owned systems.

The problem facing the investor-owned utilities will also affect BPA's other customers as well. In June 1976, BPA issued a Notice of Insufficiency to all its publicly-owned customers indicating that future load growth could not be met by BPA when the contracts with the publicly-owned utilities expire in 1983. In additon, BPA has established a public quasi-rulemaking procedure to determine how best to allocate the power that currently goes to the direct service customers, when their contracts begin to expire in the early 1980s.

The inability of the hydroelectric system to meet the competing demands of the entire region has been projected by BPA for some time. Because of this, BPA and the region's utilities in the late 1960s developed the Hydro-Thermal Power Program.

Phase 1 of that plan called for the construction of seven large thermal plants (five nuclear, two coal), as well as expansion of the federal transmission system and of the generating capacity at existing hydroelectric facilities. The plants were expected to be completed by 1981. At the moment, only two coal plants and one nuclear plant are completed and the others are not expected to be completed before 1985 .

Phase II of the Hydro-Thermal Program, formulated in late 1973, envisioned the construction of seven additional thermal plants. Phase II has been aelayed since 1975 as a result of litigation in the U.S. District Court of Oregon. 
As part of the Hydro-Thermal Program, a procedure called "net billing" was developed under which BPA would purchase the output from some of the new thermal plants for transmission to its customers.

When the Hydro-Thermal Program was originally developed, the cost of thermal power plants were expected to be only slightly higher than the region's existing hydroelectric dams. The dams provided very inexpensive power; their low cost and the seemingly inexhaustible supply of hydroelectric power contributed to the region's widespread electrification.

However, the cost of thermal power plants has risen dramatically over the last decade, as fuel costs have soared, labor costs have risen, construction problems have developed, and regulatory reviews have extended the time required for power plant siting. The rates for thermal power plants have risen to such a degree that comparable investor-owned utilities which are not receiving federal hydroelectric power on a firm basis, have frequently charged rates two to three times higher than those charged by publicly-owned systems which are receiving power from BPA on a firm basis.

BPA currently sells its power at a wholesale rate of 4 mills per kilowatt hour. (A 1979 proposed rate increase would result in a cost of approximately 8 mills per kilowatt hour.) In contrast, thermal power plants are producing power at rates of 12-16 mills per kilowatt hour, and costs of thermal plants in the region currently under construction are expected to average as high as $\mathbf{3 0}$ mills per kilowatt hour. Of BPA's 1979 rate increase request, approximately 72 percent is due to the inclusion in its system of the net-billed thermal plants.

This dramatic disparity between existing system costs and the incremental cost of new thermal plants presents some unique opportunities and problems for geothermal development. As discussed elsewhere in this report, most known geothermal resources in Oregon appear to be suited for direct use applications, rather than electrical generation, at least in the near term. Given the widespread use of electric resistance space heating in the region and the region's generally high degree of electrification, geothermal energy as a replacement for electric end-uses is particularly well-suited for Oregon and the region generally. As a replacement for electric end-uses, however, geothermal energy must prove economically competitive in order to gain widespread voluntary utilization. 
The Pacific Northwest thus presents a unique opportunity for geothermal development to replace electric space heating and other electric end-uses. This is particularly true in light of the incremental cost of new thermal generating stations. However, while the incremental costs are high, system-wide electric costs in the region are still relatively low compared to most region's in the country because of the large amount of hydroelectric power (for both public and private systems) that goes into the average system cost. Geothermal development thus must compete against a lower average system cost even though the thermal incremental cost for electric power is much higher than the existing average. This problem has been recognized and may be mitigated in part by pending federal legislation.

U.S. Senator Henry Jackson of Washington State has introduced S. 3418 to address a number of regional energy issues, including the allocation of federal hydroelectric power, development of a regional conservation program, and coordinated regionwide planning of future electric facilities. Of particular significance to geothermal development is the bill's proposal for purchase by $\mathrm{BPA}$ of energy resources from the region's utilities.

The bill authorizes BPA to purchase thermal resources needed to meet its projected load only after first implementing all cost-effective conservation measures and funding cost-effective renewable resource measures. The bill recognizes that the contribution from renewable resources can be either in the form of electric energy or as a replacement for electric end-uses. The cost-effective test compares the cost of renewable resources to the incremental cost of thermal generating stations. Should the bill be enacted, these provisions should provide a significant incentive to the development of geothermal energy. 
$\checkmark$ 


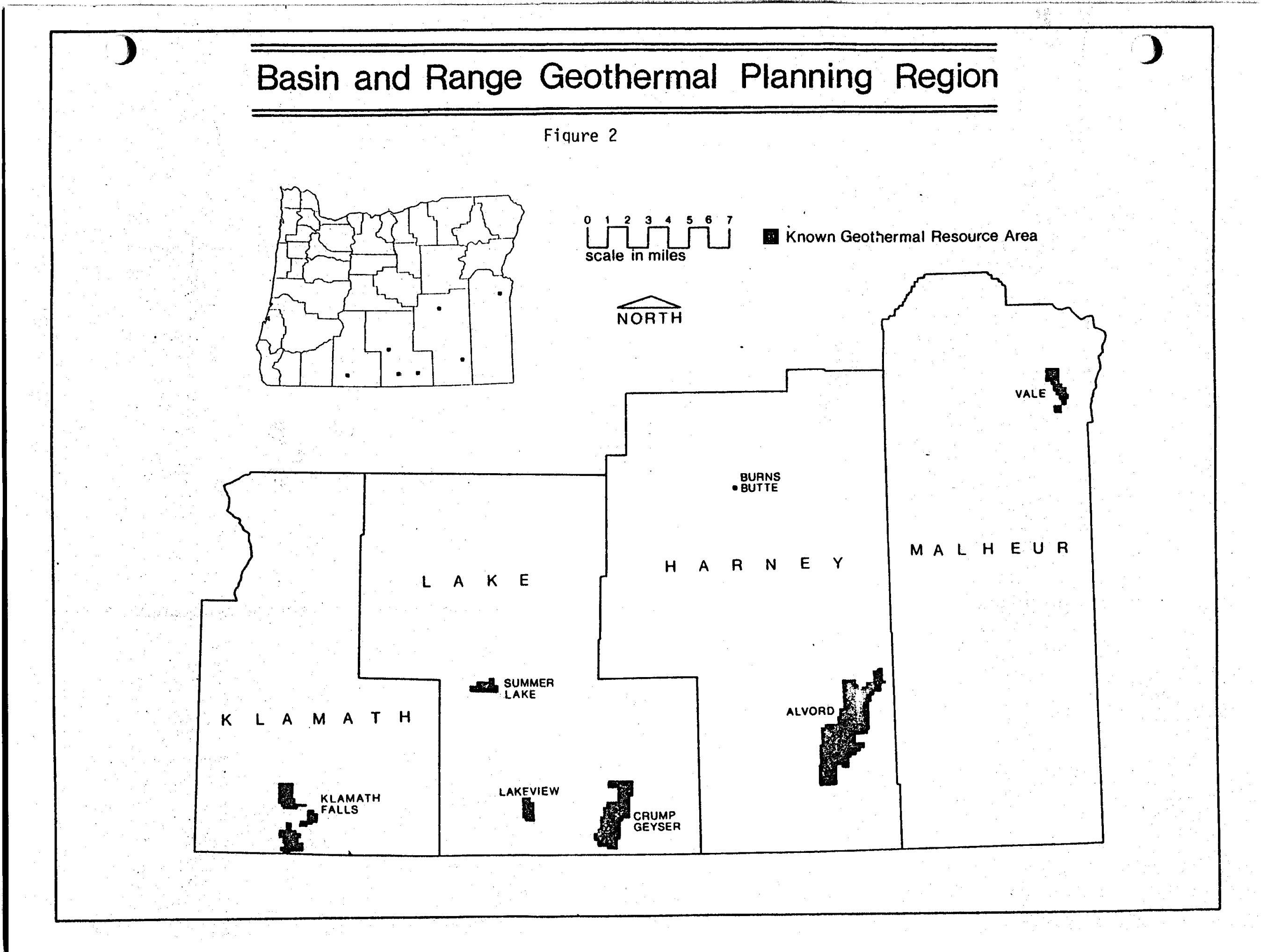




\section{BASIN AND RANGE GEOTHERMAL PLANNING REGION}

The Basin and Range geothermal planning region extends across southern Oregon from the southern Cascades east to the Owyhee Upland. The area is a small portion of the vast Basin and Range Province covering parts of Nevada, California, Arizona and New Mexico.

The topography is characterized by generally north-trending narrow ridges separated by basins of various size. Many of the ranges are steep on one side and gently sloped on the other as a result of block faulting and tilting. Most of the basin floors are covered with alluvial sediments and contain intermittent lakes and playas. Klamath Lake, Oregon's largest natural lake, is situated in one of the major structural valleys. Many of the basins are internally drained.

Population concentrations vary widely in the region from the Alvord Valley where the largest community has 11 residents to the densely inhabited Klamath Falls urban area. The only communities with populations more than 500 are Lakeview and the Klamath Falls metropolitan area.

The economy of the region is based almost exclusively on available natural resources. Livestock production is of primary importance and depends heavily on public lands for cattle grazing. Secondary activities include limited agriculture, timber and wood products industry and recreation. Products in the region are somewhat isolated from mass markets because of the area's remoteness from major transportation routes.

The Basin and Range region is also characterized by numerous hot springs, and contains areas of existing geothermal resource utilization at Klamath Falls and Lakeview. Klamath Falls has the largest concentration of direct use geothermal applications in the U.S. Yet, it is widely believed that the potential in the Klamath area has barely been tapped.

The region on the whole has outstanding potential for geothermal energy development. The possibility of temperatures sufficiently high for electric power production remains an unanswered question. Nevertheless, there is high probability of geothermal development for direct use applications in the commercial, industrial and residential sectors particularly in Klamath Falls and Lakeview.

The U.S. Geological Survey has classified five areas within the region as Known Geothermal Resource Areas. Each KGRA is situated in a basin and is associated with a thermal springs area. The KGRAs as discussed in detail in the following chapter are: Klamath Falls, Lakeview, Summer Lake, Crump Springs and Alvord Valley. 

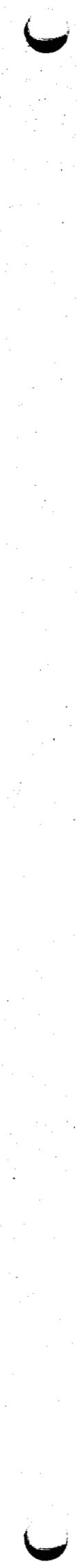



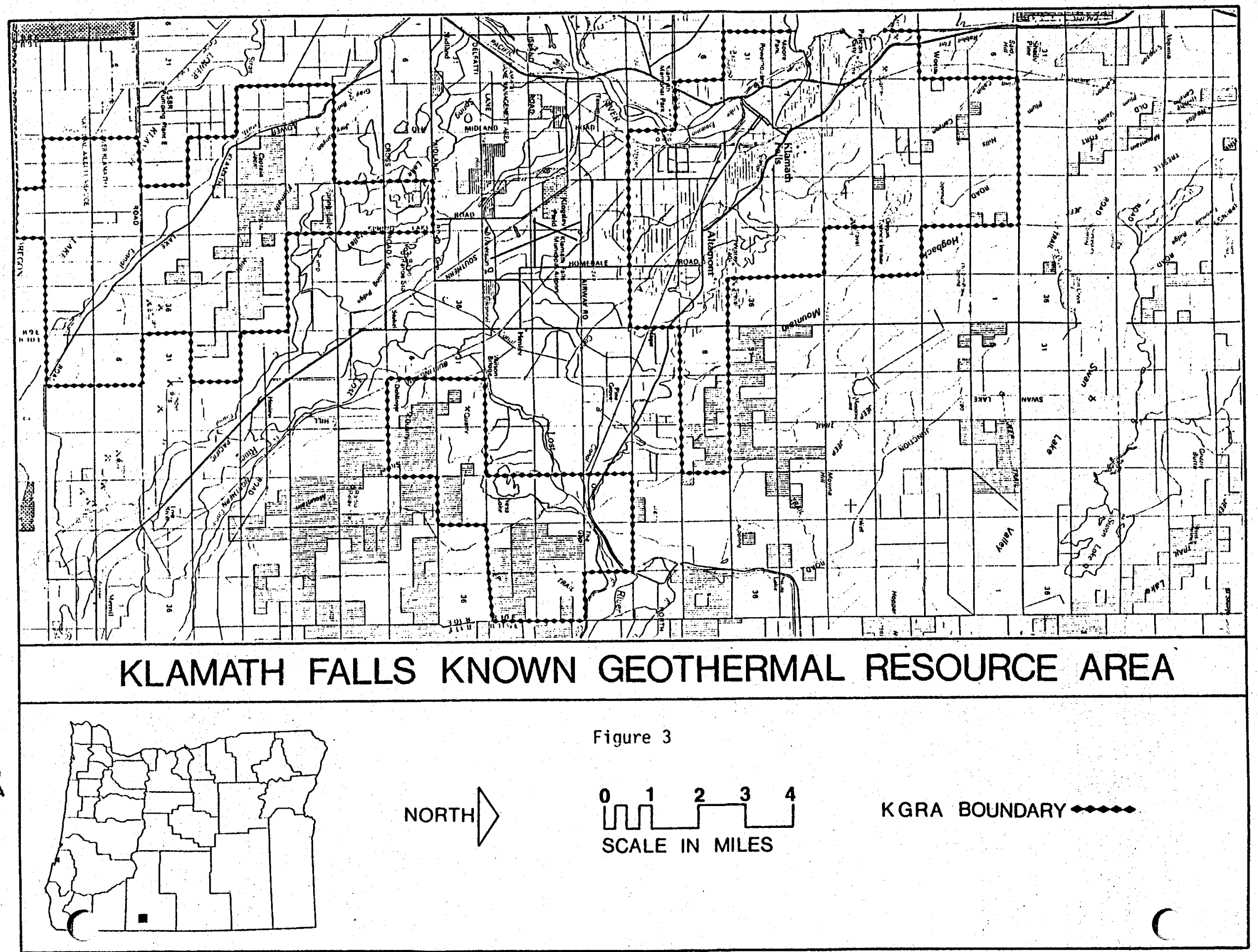




\section{KLAMATHFALLS KGRA}

Klamath Falls, situated in south central Oregon, is one of the most widely recognized geothermal resource areas in the U.S. The U.S.G.S. has designated three sections; Klamath Falls urban area, Klamath Hills and Olene Gap, as the Klamath Falls KGRA. Characteristics leading to this classification and current utilization of the resource, combined with the population concentration at the site and the existing agricultural based economy give Klamath Falls tremendous potential for commercialization of geothermal resources.

The KGRA covers 50,300 acres of predominately privately-owned land in and around the Klamath Falls urban area. Population in the metropolitan area is estimated at 45,000. The lumber and wood products industry is the largest employer. Uther economic activities are also based on the area's natural resources and include agriculture, livestock production and recreation. Principal crops are potatoes, feed grains and alfalfa. With this economic base the Klamath Falls area is prime for geothermal development to meet the energy demands for industrial processing.

Residents and several commercial establishments have already accrued significant benefits from geothermal development primarily in the form of spoce and hot water heating. Klamath Falls boasts the largest concentration of direct use applications of geothermal energy in the country. Utilization is estimated at $60 \mathrm{MWt}$ during peak winter use.

These uses include a variety of applications of which space heating is the most widespread. Approximately 400 wells supply thermal water for heating 500 structures including: single and multiple family dwellings, most all of the public schools, the Oregon Institute of Technology (OIT) campus, the community hospital, and commercial buildings. Most homes in the eastern portion of the city are heated by hot water. The common heating method is a downhole heat exchanger which utilizes city water to extract heat in a closed loop system. Other geothermal applications are somewhat unique and include; milk pasteurization, snow and ice melting from highway pavement and sidewalks, floor warming in a cold storage plant to prevent freezing and frost heaving, accelerated curing of concrete, heated swimming pools, giant prown aquaculture and greenhousing. Many of the wells drilled to provide hot water for these uses are 70 to $100 \mathrm{~m}$. deep which substantiates the existence of geothermal resources at shallow depths. 
The use of geothermal resources is not a new development in Klamath Falls. Indians and sheepherders made use of the hot springs even before the area was settled. Shortly after the turn of the century the first wells were drilled to supply hot water for home heating.

Because the resource has been used for a long time, good information is available on the characteristics of the shallow resource and practical methods of utilizing the thermal waters. However, the nature of the heat source, the potential for high temperature resources at depth and the extent of shallow reservoirs is not well understood. Information regarding existing uses and known reservoir characteristics is briefly summarized in the data sheet which follows this section. For those interested in additional and more detailed information, selected references for Klamath Falls have been included following the data sheet.

Geothermal resources in the Klamath Basin exist because of a favorable geologic environment. A heat source at depth transfers heat along faults and into shallow reserviors controlled by the porous and permeable zones in factured basalts. Lacustrine deposits act as a cap rock which concentrates heat in a confined area. Extensive faulting provides additional zones of porosity and allows thermal waters to manifest at the surface as hot springs. The location of most thermal springs appears to be fault controlled. Many of the original hot springs in Klamath Falls have disappeared, but widespread silicification attests to recent hydrothermal activity of considerable magnitude.

Thermal activity is also expressed at the surface by several steamers on the east side of the city. This natural steam was encountered during drilling at very shallow depths and is used to heat city water in a downhole heat exchanger to provide residential space heating.

Peterson and Groh (1967) suggest that the cap rock acts as a barrier to any existing deep geothermal reservoir. Based on chemical analysis, they postulate that the thermal fluid providing heat into the geothermal zones is probably steam. If these assumptions are accurate then high temperature resources, potentially in the range of consideration for power generation, could be encountered at depth. Nevertheless, since deep test drilling has yet to confirm this theory, the most beneficial apparent use of geothermal resources is for direct use applications. 
The potential for non-electrical uses such as space heating and industrial applications is vast. Based on a minimum estimated temperature of $130^{\circ} \mathrm{C}$ and a reservoir size of $240 \mathrm{Km}^{2}$ by $2 \mathrm{Km}$ thick the heat content is $30 \times 10^{18}$ calories. Estimates by White and Williams (1975) of the beneficial heat assuming a recovery of 25 percent at the surface and a utilization efficiency of 25 percent give a value of $1.5 \times 10^{18}$ calories available for use. Heat content in the shallow reservoir is estimated to be in the range of $12 \times 1018$ calories to $36 \times 10^{18}$ calories, which could be among the larger thermal systems in the United States (Lienau, et. al., 1978). Culver (1978) estimates that the Klamath Falls urban area has a potential of $200 \mathrm{MWt}$ using existing wells.

Obviously the potential for geothermal resource utilization is much greater than what is presently being tapped. Local entities are well aware of this fact and are undertaking projects to expand the use of their indigenous energy resource.

Of particular note is the current project to establish a geothermal heating district. The City, Klamath County, State of Oregon and the U.S. Department of Energy are participating in a demonstration project which initially will provide service to fourteen public buildings in the downtown area. Exploration and development time prior to bringing "power-on-line" is short since the location of the resource is relatively well understood. Therefore, the system is expected to be operational in early 1981, and should provide an additional 7 to $10 \mathrm{MWt}$ to existing utilization. Within 5 to 10 years expansion of the district system to include 110 commercial buildings in the central business section could provide utilization of $54 \mathrm{MWt}$ which is nearly equal to the peak use of existing applications.

The City of Klamath Falls in 1978 undertook a the development of an industrial park site capable of supplying thermal fluids for process heat. Three test wells were drilled adjacent to and north of the OIT campus. Measured gradients were essentially isothermal. This lack of success illustrates that much remains to be learned about the nature and extent of the Klamath Falls geothermal resource. These holes were situated less than one kilometer from the producing wells which heat more than 500,000 square feet of building space on the OIT campus. Other options are being explored to site a geothermal industrial park in the area.

These projects should result in increased use of the local resource, but there will still be a significant amount of untapped potential. Awareness of this potential has stimulated two major studies of probable end-use applications of the identified intermediate temperature resources. 
The first of these is an evaluation of the potential for industrial and agricultural processing using geothermal energy by Reistad and others (1978). Economic and engineering feasibility studies of selected industrial processes were based on comparisons of using geothermal energy at present costs relative to natural gas. The agri-industrial processes considered include: swine raising, greenhouses, methane production, barley malting and lumber drying.

Production costs for each process except methane production were estimated to be lower for geothermal systems than for natural gas. Greenhouses on a commercial scale were viewed as competitive in the current market. Development of a 15 acre greenhouse operation in the Klamath Hills area supports these findings.

Other processes were considered non-competitive now because of particular economic factors. Although barley grown locally could supply a large portion of a malt plants' raw product, the railroad rate structure puts the Klamath area at a competitive disadvantage when compared to other malting plant locations on the west coast. Kiln drying of lumber is restricted by the availability of low cost wood wastes fuel. Swine production does not currently exist in the area primarily because supplemental feed costs are high.

When these processes are considered as an integrated system the economics are more encouraging. Integration would provide more efficient use of the resource by cascading processes from high temperature to lower temperature applications. It would also allow waste products of one process to be benefically used by another. For instance, by-products from barley malting could provide feed for the swine operation which in turn provides waste for methane generation. This integration further reduces the production costs of each process.

The second major study was completed by Lienau and others (1978) of the Geo-Heat Utilization Center at OIT. Three prospective industries, onion dehydration, alfalfa drying and greenhouses were examined. In addition, a detailed economic analysis and preliminary engineering design were determined for an existing starch extraction plant in the Klamath Basin.

Western Polymer Corporation situated $33 \mathrm{~km}$ south of Klamath Falls processes 14 tons of potatoes per hour for starch extraction. On an annual basis the plant consumes 122,250 gallons of propane, of which 85 percent is used for starch drying. 
Three options were considered for retrofitting to a geo-system. The most attractive option calls for deepening an existing well in hopes of encountering a $180^{\circ}$ to $200^{\circ} \mathrm{F}$ resource. Thermal water would be piped to a heat exchanger which would supply heat for processing and provide reject water for space heating the building. The system would supply 76 percent of the thermal energy requirements for space and process heat. Capital outlay is estimated at $\$ 124,800$ with a 49 percent return on investment and a two year pay back period.

Onion dehydration was examined because of the existence of onion producing areas in the basin and the large quantities of low temperature energy consumption in the process. Resources in the Klamath Basin are capable of providing the desired $200^{\circ} \mathrm{F}$ temperature. Cost analysis was based on the comparison of a conceptual model using geothermal energy as opposed to conventional fuels. Results indicate that the plant would have to operate only 180 hours per year with a geothermal system to be competitive with natural gas.

Alfalfa dehydration was evaluated because of the large quantities of alfalfa grown in the area and the potential foreign export market for alfalfa processed with low temperatures. Fuel drying produces a harder and heavier pellet which retains more Vitamin $A$ and xanthrophyll which increases marketibility. The analysis of a plant producing 25,000 to 30,000 tons annually with a combination of field wilting and fuel drying indicates that a savings of $\$ 100,000$ per year could be realized over the cost of a conventional fuel system.

Cost analysis for a 15 acre greenhouse operation indicates a significant competitive advantage for geothermal heating systems compared with natural gas. Tree seedlings were identified as the most attractive crop now for local markets. Bedding plants, flowers and vegetables are viable candidate crops, as well, given the short growing season in the basin.

Clearly, there is a wide range of industrial energy uses that could convert to geothermal given the proven resource and the agricultural based economy of the Klamath Basin. The apparent barrier to development is lack of financial incentives. Geothermal development is a capital intensive undertaking which is often considered as "too risky" by lending institutions. Easily obtainable federal guaranteed loans, reservoir insurance and willingness of lenders to fund alternate energy projects would stimulate expanded use of this local energy source. 
Another problem involves the question of disposal of geothermal effluents. The development of existing use has taken place in a very unsystematic manner. Consequently, many geothermal systems waste reject fluids into the sewers or other surface disposal. Regulations have been formulated which restrict such disposal. It is believed, however, that large scale development of a heating district and a cascaded geothermal system in an industrial park will provide the basis for the necessary coordinated resource planning. Such planning will facilitate effective disposal techniques and concentrate energy users to make more efficient use of the resource. 
SITE DATA SUMMARY

SITE: KLAMATH FALLS KGRA, OREGON

..Phys ical Reservoir Date

.. Temperature ${ }^{\circ} \mathrm{C}$

Surface: $74^{\circ} \mathrm{C}$

(1)

Subsurface: $120^{\circ} \mathrm{C}$

.. Total Dissolved Solids: $900 \mathrm{mg} / 1$

..Type of Overlaying Rock: Pliocene volcanics, lake bed sediments

... Est imated Depth to Top of Reservoir (meters): $1,000 \mathrm{~m}$.

.. Site Land Status

Total Acres - 50,300 (KGRA)

Total Acres Leased - FED.: $0 \quad$ PRIVATE: Undetermined

..Geothermal Development Status:

Extensive use of non-electrical applications for a variety of purposes, primarily space and domestic hot water heating. It is believed that only a small portion of the area's geothermal potential is utilized.

..Local and State Attitude Toward Geothermal Development:

Locals have realized the benefits of geothermal development for decades and encourage further development. However, homeowners with geo-heating systems are concerned about the effects of expanded development on the fr wells.

The City of Klamath Falls is actively encouraging further development.

-Land Use and Population:

The majority of the population of Klamath County lives in the Klamath Falls area.

Land uses are diversified, ranging from livestock raising and agriculture to densely populated urban areas. 


\section{SITE LOCATION AND PHYSICAL DESCRIPTION}

\section{SITE: KLAMATH FALLS KGRA}

-. Latitude: $42014^{\prime} \mathrm{N}$

..Longitude: $121046^{\prime} \mathrm{W}$

.. Rectilinear:

Secs. $3,4,5,8,9,10,14-22,26-35$, T.38S., R.9E, Willamette Meridian (W.M.)

Secs. 1-5, 9-12, T.39S., R.9E.,

Secs. $3,10,15,16,17,20-28,34-36$, T.40S., R.9E.,

Secs. $1-4,9-12,15$, T.41S., R.9E.,

Secs. $4-6,14,15,22-27,32-34$, T.39S., R.10E.,

Secs. 4, 5, 30, T.40S., R.10E.,

Secs. 6, 7, T.41S., R.10E.,

.. Topography

The Klamath Basin is situated in south-central Oregon and northwestern California. The basin extends from Crater Lake to the north and Medicine Lake highland to the south. The KGRA is located near the east side and center of the Oregon portion of the basin. To the west of the area are the Cascade Mountains and to the east the high desert country.

Typical of the Basin and Range Province the area is characterized by north-trending parallel mountain ranges and valleys. Upper $\mathrm{Kl}$ lamath Lake, the largest natural lake in Oregin, is situated in the basin. Unlike other basins in the region which are generally closed, the $K$ lamath Bas in is drained by the Klamath River and its tributaries to the south into Cal ifornia and eventually to the Pacific Ocean. Elevations range from $1,250 \mathrm{~m}$. in the valleys to $2,896 \mathrm{~m}$. on mountain peaks.

..Present Land Use:

The land base supports a variety of uses ranging from livestock grazing and wildrife habitat to the densely populated urban area of Klamath Falls. Uses include irrigated agriculture, Tivestock production, recreational activities, timber production and a multitude of man-made improvements. Most of the developed land is concentrated in the valley bottoms and in tableland areas. 
The valley bottoms are generally privately owned and are used mainly for agriculture. Potatoes are the principal cash crop. Other crops include: barley, onions, alfalfa, winter wheat and feed grains. Lakes and marshes in the valleys provide important habitat for one of the largest waterfowl concentrations in North America. Plateaus are primarily rangeland areas and are of ten used in conjunction with farming and ranching operations on the val ley floor.

Man-made improvements in the valleys and foothills range from roads and railroads to highly developed urban, commercial and industrial areas. The lower elevation areas contain numerous homesites and the rural communities of Bonanza, Dairy, Olene, Merrill, Lorella, Keno, and others.

The primary land uses at higher elevations are timber production and recreation. Communication sites are located on several high peaks including; Stukel Mountain, Bryant Mountain and Hamader Mountain.

..Aesthetics:

Lakes and marshes in the area are extremely important for waterfowl habitat.

The Environmental Analysis Report classifies the area as having intermediate scenic value.

..Historical/Archaeological Significance:

An known archaeological area is located in T.40S., R.9E. in the KGRA.

The Baldwin Hotel and Lower Klamath National Wildl ife Refuge are listed on the National Register of Historic Places. Historic Trails - Topsy Grade and Applegate Trail.

Indian artifacts and occupation sites are also found in the area. 


\section{GEOLOGICAL/GEOPHYSICAL DESCR IPTION}

\section{SITE: KLAMATH FALLS, KGRA}

\section{...Geologic Description:}

The geologic summary is based primarily on Peterson and Groh (1967) and Peterson and McIntyre (1970).

The stratigraphy of the Klamath Fal Is area is complex...Pliocene and Pleistocene volcanic activity with concurrent sedimentation and volcanism has resulted in a heterogeneous sequence of volcanic and sedimentary rock. Thickness and composition of rock types varies greatly.

The oldest exposed rocks are Pliocene and Pleistocene basaltic lava flows. Newcomb and Hart (1958) called the older basalt flows the "lower lava rocks" ( 0 to $250 \mathrm{~m}$. thick). This unit is overlain by the Yonna Formation ( 50 to $300 \mathrm{~m}$. thick) of Pliocene age. The unit is composed of lactustrine diatomite, tuffaceous siltstone, sandstone, palagonite tuff, basaltic tuff and minor basalt flows.

The Yonna Formation is overlain by a unit of basaltic lava flows and breccia ( 5 to $30 \mathrm{~m}$. thick). This younger basaltic volcanism is of Plio-Pleistocene age. These flows are overlain by lacustrine, terrace and alluvial deposits of varying thickness primarily in the structural basins.

In general, the fractured basalts and cinders are highly porous. They are capped by the nearly impervious zone of the Yonna Formation consisting of fine grained, lacustrine, palagonite and tuff sediments and diatomite. The unit is locally known as "chalk rock". In localized areas such as above the Presbyterian Intercommunity Hospital the unit has been hydrothermally altered to various silicious deposits including procelainite and opal breccia, locally called "hot springs. agates" (Lund and others, 1978). These areas indicate that hydrothermal activity has been more extensive than at present.

Basaltic volcanism in the Klamath Basin has been nearly continuous since Pliocene time. Pleistocene volcanism is evidenced by scattered cinder cones, thin basalt flows in the $K l a m a t h F a l l s$ area and extensive flows east and northeast of the city. 
The dominant structural features are numerous north-west trending faults. Peterson and McIntyre (1970) have characterized the faults by relatively small displacements, close spacing and consistency in strike pattern. Displacements along the faults are generally less than $152 \mathrm{~m}$. However, several faults along the east side of Upper Klamath Lake, Bryant Mountain and Swan Lake exceed $305 \mathrm{~m}$. of vertical displacement. In the area of Modor Point on the east side of Upper K 1 amath Lake, at least $488 \mathrm{~m}$. of vertical displacement is indicated.

Complex faulting has broken the Klamath Basin into a pattern of northwest-trending fault-block ridges and down-dropped val leys. Most of the faulting occurred in late Pleistocene time. This horst and graben topography is characteristic of the Bas in and Range Province.

The $\mathrm{k}$ lamath graben is approximately $56 \mathrm{~km}$ wide and $160 \mathrm{~km}$ long extending from Crater Lake caldera to the north and in the south to the Medicine Lake Highland volcanic area in California. The graben is bounded by a series of parallel northwest-trending normal faults with dips ranging from $55^{\circ}$ to $70^{\circ}$. Locally, smaller horst blocks protude above valley floors such as Klamath Hills and Stukel Mountain.

\section{..Geothermal Phenomena:}

The occurrence of geothermal resources in the Klamath Falls area as summarized by Lienau and others (1978) is presented below:

The pattern of hot springs, hot-water wells and hydrothermally al tered rock indicates geothermal activity over a long period of time in the Klamath basin in areas including the Klamath Falls urban area, Olene Gap, southwest Klamath Hills, and near Lorella in the Langell Valley.

The majority of geothermal anomalies appear as narrow, elongate zones paral leing faults or fault blocks within the basin. This has led to one interpretation that the thermal waters originate from deep circulation of meteroric waters with convective transfer of heat and fluid from depth with permeable zones along some of the major faults. Other interpretations suggest a magnatic heat source.

Sammell (1976) concludes that the Klamath Falls area is under lain by an intermediate temperature $\left(900\right.$ to $\left.130^{\circ} \mathrm{C}\right)$ convective geothermal system. This interpretation is based primarily on the geothermometer indicated reservoir tmperature of $130^{\circ} \mathrm{C}$. Based on the estimated reservoir temperature, Samme1l (1976) suggests that the thermal waters are produced by 
deep circulation along the fault zones to depths of 3 to $4.3 \mathrm{~km}$ in a region of a normal geothermal gradient of $30^{\circ}$ to $40^{\circ} \mathrm{C}$ per $\mathrm{km}$. Based on the assumption that the hot water is produced through the mechanism of deep circulation in the fault zones, Samme11 (1976) concludes that the hot waters are generally restricted to three areas: Klamath Falls/Altamont, Klamath Hills, and Olene Gap.

Lienau and others (1978) suggest that the thermal waters are more abundant and widespread than postulated by Sammel1 (1976). The assumption is based on the belief that the geothermal gradient and heat flow of the region is much higher than the gradient reported by Samme11 (1976) and Sass and Sammel1 (1976). From studies of the Klamath basin, Lienau and others (1978) suggest that the regional gradient is closer to $75^{\circ} \mathrm{C}$ per $\mathrm{km}$. They conclude that if the regional gradient is in the range of $75^{\circ} \mathrm{C}$ per $\mathrm{km}$, water with sufficient temperature for space heating $\left(45^{\circ}\right.$ to $\left.50^{\circ} \mathrm{C}\right)$ should be encountered regionally at depths of 0.5 to $0.6 \mathrm{~km}$. Higher temperature water $\left(90^{\circ}\right.$ to $110^{\circ} \mathrm{C}$ ) would be expected adjacent to faults. It is probable that deeper drilling to depths of 1.5 to $2 \mathrm{~km}$ will encounter waters at least as high as $130^{\circ} \mathrm{C}$, the estimated base reservoir temperature (Lienau and others, 1978).

.. Hot Springs:

The most numerous and highest temperature hot springs occur in the Klamath graben. In several surrounding valleys there are many wells which yjeld warm water. The major zones are Klamath Falls, Klamath Hills and 0 lene Gap. Warm water well areas are: Merrili-Mal in, Poe Valley, Langell Valley, Sprague River Valley and southeast of Klamath Falls. Data from each of these areas is summarized below:

Klamath Falls: Wells along this $7 \mathrm{~km}$ zone provide space heating for a considerable portion of the eastern section of the urban area. Temperatures range from $21^{\circ}-121^{\circ} \mathrm{C}$ with a geochemically determined minimum reservoir temperature of $136^{\circ} \mathrm{C}\left(\mathrm{SiO}_{2}\right)$ and $130^{\circ} \mathrm{C}(\mathrm{Na}-\mathrm{k}-\mathrm{Ca})$. The zone shows surface evidence of silicification and hydrothermal alteration and is structurally controlled by a northwest-trending fault system. (10)

Klamath Hills: There are no surface manifestations of geothermal activity, but wel1 temperatures range from 270 to $90^{\circ} \mathrm{C}$ with maximum flows of about $19,000 \mathrm{lpm}$. The area has been extensively silicified. The geothermal zone is controlled by northwest-trending faults along a horst block, (10) 
Olene Gap/Poe Valley: The hot springs measured with low levels in the Lost River ranged in temperature from $70^{\circ}$ to $81^{\circ} \mathrm{C}$ on the south bank of the river. The largest spring on the north bank had a high temperature of $87^{\circ} \mathrm{C}$ Geochemically determined minimum reservoir temperature is $80^{\circ} \mathrm{C}$. The 0lene Gap anomaly may extend south and westward in a zone approximately one $\mathrm{km}$ wide surrounding Nuss Lake and extends west and south around the northwest point of Stukel Mountain. (10)

Merrill-Malin: Springs and well logs indicate several areas of moderate temperature ranging from $50^{\circ}$ to $100^{\circ} \mathrm{C}$. Three areas of potential are indicated: west flanks of Stukel Mountain, south side of Stukel Mountain extending east and southward to Adams Point halfway between Merrill and Malin, and three small areas northwest and south of Merrill in the eastern most part of the Klamath Hills. (10)

Langell Valley: Shallow groundwater wells are generally of normal temperature. Exceptions include a narrow northwest-trending zone that includes Big Hot Spring southwest of Lorella with a temperature of $61^{\circ} \mathrm{C}$. (10)

Sprague River Valley: Groundwater wells between Beatty and Sprague River report temperatures from $11^{\circ}$ to $22^{\circ} \mathrm{C}$ at shallow depths. (10)

\section{-.Geophysical Summary:}

There is a considerable amount of geophysical data available covering the Klamath Falls geothermal area. References to selected studies are sited below:

Berg, J. W., Jr., and Thiruvathukal, J. W., 1967, Complete Bouguer Gravity Anomaly Map of Oregon: Oregon Dept. of Geology and Mineral Industries, Map GMS 4-b.

Bodvarsson, G., Couch, R. W., MacFarlane, W. T., Tang, R. W., and Whitsett, R. M., 1974, Tel luric Current Exploration for Geothermal Anomalies in Oregon: Ore Bin, Vol. 36, No. 6, pgs 93-106.

Sass, J. H., and Sammel1, E. A., 1976, "Heat Flow Data and Their Relation to Observed Geothermal Phenomena near Klamath Falls, Oregon", Journal of Geophysical Research, Vol. 81, No. 26, pgs. $4863-4868$.

Senterfit, R. M., and Bedinger, G. M., 1976, Audio-Magnetotel lur ic Data Log and Station Location Map for the Klamath Falls Geothermal Resource Area, Oregon: U.S.G.S. Open-file Report 76-320. 
U.S.G.S., 1972, Aeromagentic Map of the Klamath Fal is and Part of the Crescent 10 by $2^{0}$ Quadrangles, Oregon: U.S.G.S. Open-file Report.

\section{..Exploration Drilling:}

\section{Hunt oij Company}

Drilled ten $91 \mathrm{~m}$. gradient wells in 1978.

Drilled twelve $152 \mathrm{~m}$. gradient holes in 1978.

City of Klamath Falls

Compelted drilling three gradient wells in 1978.

Weyerhaeuser-Pacific Power \& Light Co.

Drilled a $611 \mathrm{~m}$. gradient hole in 1976 .

Thermal Power Company

Drilled seven $61 \mathrm{~m}$. holes in 1972.

Drilled seven $61 \mathrm{~m}$. gradient wells in 1975.

Planned to drill a 2,438 m. gradient hole in 1976. Well was abandoned due to drilling difficulties at $1,780 \mathrm{~m}$.

U.S.G.S.

Drilled two $183 \mathrm{~m}$. gradient holes in 1974. 


\section{RESERVOIR CHARACTERISTICS}

\section{SITE: KLAMATH FALLS KGRA}

..Reservoir Temperature

.. Surface: $740^{\circ} \mathrm{C}$

..Subsurface: ${ }^{120^{\circ} \mathrm{C}}$

.. Geochemical

$$
\mathrm{SiO}_{2}: 136^{\circ} \mathrm{C}
$$

Na-K-Ca: $130^{\circ} \mathrm{C}$

..Flow Rates:

Klamath Falls area wells range 95-1,514 $1 \mathrm{pm}$ (1 iters per minute)

Klamath Hills area wells as high as $18,927 \mathrm{lpm}$

(4)

..pH: 7.5 to 8.5

.. Total Dissolved Solids: $900 \mathrm{mg} / 1$

..Fluid Chemistry:

Geothermal well water is generally characterized by high concentrations of sodium and low concentrations of potassium. Typically water hardness is low and results principally from calcium ion. Total dissolved solids are approximately $900 \mathrm{mg} / \mathrm{l}$. (4)

Wells that provide heat sources share certain chemical composition patterns. These include: high cation concentrations of silica, sodium and potassium, low cation concentration of calcium, high anion conentrations of chloride ion, low anion concentrations of water hardness and total alkalinities $\left(\sim 40 \mathrm{mg}, \mathrm{CaCO}_{3} / 1\right)$.

(4) 
Typical water chemistry of geothermal wells is summarized below and selected well chemistry follows:

\section{Geothermal Well Chemsitry}

\begin{tabular}{lccc} 
& Average & $\begin{array}{c}\text { Standard } \\
\text { Deviation }\end{array}$ & $\begin{array}{c}\text { Typical Cold } \\
\text { Water Well }\end{array}$ \\
\cline { 2 - 4 } $\begin{array}{l}\text { Specific Conductance } \\
\text { (micromhos) }\end{array}$ & 1,210 & 287 & 420 \\
Silica & 91.3 & 21.4 & 45.8 \\
Calcium & 21.8 & 8.48 & 55 \\
Magnesium & 0.2 & 0.34 & 13.7 \\
Sodium & 201 & 47.7 & 10.8 \\
& & & $($ Units $\mathrm{mg} / 1)$ \\
Potassium & 4.8 & 1.11 & 2.0 \\
Sulfate & 410 & 73.1 & 8.3 \\
Chloride & 49.1 & 7.95 & 6.8 \\
Boron & 0.78 & 0.1 & 0.16 \\
Iron & 3.06 & 6.12 & 0.23 \\
Water hardness & 78.5 & 23.1 & 194 \\
Dissolved 0xygen & 1.88 & 1.29 & 6.0 \\
pH & 8.08 & 0.337 & 7.30 \\
Temperature ( ${ }^{\circ} \mathrm{C}$ ) & 72.6 & 2.47 & 25 \\
& & &
\end{tabular}

..Estimated reservoir heat content: $30 \times 10^{18} \mathrm{cal}$.

..Estimated Non-electric Energy Potential:

200 MWt using present wells (11)

2,390 MWe estimated by USGS for industrial processing

..Subsurface Area of Reservoir: $240 \mathrm{~km}^{2}$ estimated 
..Chemical Analysis: (Units $\mathrm{mg} / \mathrm{l}$ unless otherwise indicated)

$$
\text { olene }
$$

\begin{tabular}{|c|c|c|c|c|}
\hline $\begin{array}{l}\text { Gap } \\
\text { Hot } \\
\text { Spring }\end{array}$ & $\begin{array}{c}\text { 0IT } \\
\text { Well \#6 }\end{array}$ & $\begin{array}{l}\text { Medo-Bel } \\
\text { Dairy } \\
\text { Well } \\
\end{array}$ & $\begin{array}{l}\text { Mazama } \\
\text { School } \\
\text { Wel1 }\end{array}$ & $\begin{array}{c}\text { Liskey's } \\
\text { Ranch } \\
\text { Well }\end{array}$ \\
\hline 140 & & 1,160 & & 1,030 \\
\hline
\end{tabular}

Silica

Calcium

Magnesium

Sodium

Potassium

Lithium

Bicarbonate

Carbonate

Sulfate

Chloride

Flouride

Temperature $\left({ }^{\circ} \mathrm{C}\right)$

$\mathrm{pH}$

98
40

$0.2 \quad 24.2$

190

7.2

0.15

53

400

59

1.2

74

7.68

3.9 44

0
400

58

88

8.2
81

23

$213^{.0}$

4.2

1.45

1.2

81

8.8
92

5.4

246

6.0

0.1

200

$\begin{array}{rrr}32 & 120 & 48 \\ 8 & 0 & 2 \\ 403 & 256 & 360 \\ 54 & 35 & 59\end{array}$

1.5

61

93

$8.3 \quad 8.9$

Location: 0lene Gap Hot Spring Sec. 14, T.39S., R.10E., W.M.

OIT Well \#6

Sec. 20, T.38S., R. $9 E$.

Medo-Be1 Dairy Well Sec. 28, T.38S., R.9E.

Mazama School Well Sec. 11, T.39S., R.9E.

Liskey's Ranch Well Sec. 34, T.40S., R.9E.

References: 01ene Gap Hot Spring (3)

All Others

(5) 


\section{LAND OWNERSHIP AND LEASING}

\section{SITE: KLAMATH FALLS KGRA}

. Total KGRA: 50,300 acres (estimated $30 \%$ in private ownership)

..Land Leased in KGRA: Federar Tand - 0

State land - 0

Private land - Undertermined acreage

..Tentative Lease Sale Date: None Scheduled

..Number of Sales Offered But No Bids: 20 tracts have received no bids during 3 sales.

.. Summary of Leasing Status:

Lease sales for the Klamath Falls KGRA have been held on $5 / 13 / 76,12 / 9 / 76$ and $7 / 27 / 78$. A total of 27 tracts were offered with bids received on 6 parcels. The lease units were smaller sized than usual, averaging slightly over 300 acres, and annual rental rates were set at $\$ 1 /$ acre in an attempt to attract non-electric users.

Thermal Power Company was the sole bidder in the 5/13/76 lease sale. The company leased 6 tracts totaling 1,908 acres with bonus bids ranging from $\$ 3.21$ to $\$ 15.11$ per acre. A total of 12 units were reoffered for the $12 / 9 / 76$ and $7 / 17 / 78$ lease sales, but no bids were received.

... Non-Competitive Leases Issued:

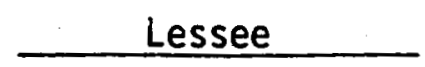

Nelson B. Hunt

W. H. Hunt

Thomas M. Hunt

Norma K. Hunt

Caroline Lewis Hunt

Hassie Hunt

\section{Total Acreage}

11,975

7,732

1,038

2,299

2,084

1,800

TOTAL $\quad 26,928$ 


\section{GEOTHERMAL DEVELOPMENT STATUS}

SITE: KLAMATH FALLS KGRA

..Historical Developments:

Hot springs were used by Indians and sheepherders before the turn of the century for scalding hogs and poultry, and as temporary residence by many transients.

In 1925, residents began drilling wells for home heating purposes. The first down-hole heat exchanger was placed in service in 1929. In 1928 a natatorium with a swimming pool and hot mineral baths was constructed on the site of the present high school swimming pool.

..Present Development Status:

Residents in Klamath Falls have utilized geothermal resources principally for space heating at least since the turn of the century. It is estimated that approximately 400 wells meet the space and hot water heating requirements of 500 structures. This utilization includes the heating of homes and businesses, most all of the city schools, Oregon Institute of Technology campus, a hospital, a creamery (for space heating and milk pasteurization), melting snow and ice from sidewalks and a highway pavement, keeping a floor from freezing and frost heaving in a cold storage plant, accelerated curing of concrete, direct use in a laundry, and for heating swimming pools. Geothermal effluent from the OIT heating system is used in a cascaded fashion to heat an experimental greenhouse and to grow giant prawns (Macrobrachium Rosenbergii).

Most of the present wells for homes vary between 30 and $300 \mathrm{~m}$. in depth with 70 to $100 \mathrm{~m}$. being the most common. Commercial buildings and schools which require a greater heat output have an average well depth of 300 to $400 \mathrm{~m}$. Depth to the water surface varies from artesian to $107 \mathrm{~m}$. with 15 to $30 \mathrm{~m}$. most common. (8)

Currently most of the eastern portion of the city is heated by thermal water. The principal heat extraction system is the downhole heat exchanger which utilizes city water in a closed loop system. (8)

Total heat utilization from hot water wells in Klamath Falls urban area is approximately 6 MWt, with 15 MWt being used on the average during the winter and about 60 MWt peak use. (4)

It is believed that only a small portion of the area's potential is being utilized, with speculation that a high temperature steam area exists beneath the known shallow reservoir. 
...Projected or Planned Development:

A project has been initiated by the City of Klamath Falls to establish a geothermal heating district. Engineering and design studies were being conducted during late 1978. Several wells were pump tested during the summer. The system is scheduled to be in operation by early 1981 and will initially serve fourteen public buildings.

It is estimated that the system will provide an additional 7 to 10 MWt of geothermal energy. (9) Continued development is planned to expand the system to include space heating for approximately 110 comercial buildings in the central business district.

The expansion of the district could increase geothermal energy utilization by an estimated 54 MWt. This total which could be realized within 5 to 10 years is over three times the average amount of geothermal energy now being used in Klamath Fal is. Additional energy could be provided as the system expands into the surrounding neighborhoods in the long term.

A commercial greenhouse operation is underway on a ranch in the $K$ lamath Hills area. The first increment of one acre houses has been constructed and is successfully producing tree seedlings. Plans call for the construction of 15 acres of greenhouses.

The City of $\mathrm{Klamath}$ Fall ls began drilling test wells in the area just north of the 0IT campus in mid-1978. The proposed use was to supply process heat for an industrial park. Results of the test drilling were not encouraging. However, it is assumed that alternatives will be explored to establish a geothermal industrial park.

Individual wells for home heating will continue to be drilled at the rate of several a year. 


\section{INSTITUTIONAL CONSIDERATIONS}

\section{SITE: KLAMATH FALLS KGRA}

\section{..Institutional Requirements:}

Klamath County has a special zone classification, SP-16, for dealing with activities such as geothermal development. Under the zoning ordinance, exploration and development for geothermal resources may require application to the County for a SP-16 zone change and a conditional use permit.

The City is considering a geothermal ordinance to deal with conservation of the resource.

A permit is required by the City for drilling a hot water well within the city limits.

Most geothermal wells in the area have been drilled under water well permits due to the shallow depth of the reservoir.

.. Agency and Public Attitudes:

Local residents are very much aware of the uses of geothermal energy and appear favorable toward expanded use of the resource.

Some residents who have geothermal heating systems fear that additional exploration and development could deplete their existing heat source.

State, County and local governments are supporting geothermal development by contributing funds to a cost shared demonstration project for a geothermal heating district.

..Status of Requirements (i.e., EIA/EIS Requirements):

The Lakeview and Medford District Offices of the BLM completed an EAR addressing geothermal leasing in the Klamath Bas in in 9/74.

Comprehensive land use $\mathrm{plans}$ for $\mathrm{K} \mathrm{l}$ amath County have not been completed. 


\section{ENVIRONMENTAL FACTORS}

SITE: KLAMATH FALLS KGRA

\section{..CLIMATE}

...Prevailing Winds: West and South

..Precipitation (Annual): $36.4 \mathrm{~cm}$.

..Days of Sunshine (Annuar): 275

.. Average Temperature $\left(47.5^{\circ} \mathrm{F}\right)$

Minimum: $\quad(29.70 \mathrm{~F})$

Maximum: $(67.90 \mathrm{~F})$

..Degree Days (Annual): 6516

..Relative Humidity: Low

\section{..AIR QUALITY:}

Total suspended particulates are monitored in $\mathrm{Kl}$ amath Falls and at the OIT campus. The particulate concentration averages 80 micrograms/cubic meter $\left(\mathrm{mg} / \mathrm{m}^{3}\right)$ in $\mathrm{Klamath} \mathrm{Falls}$ and $38 \mathrm{mg} / \mathrm{m}^{3}$ at 0IT. The Klamath Falls average is slightly above Oregon's ambient air quality standard (60 mg/m of air, as an annual mean).

Primary sources of particulates include: agriculture, industry, nature and the community. Nature and agriculture contribute pollen and dust from barren 7 and and dry lakebeds. Industrial activities add dust, smoke and wood particles to the air throughout the year. Smoke during the winter results from residential heating by wood and oil.

Automobile exhaust is the principal source of noxious gases.

Hydrogen sulfide is dispersed into the air by some of the hot springs in the area. Concentrations range from 0.03 to $0.002 \mathrm{ppm}$ in the immediate vicinity of the springs. 
.WATER QUALITY:

Groundwater is generally of excellent quality with relatively low hardness and dissolved solids concentrations. The groundwater resource is large.

Surface water has a wide quality range. Upper Klamath Lake is eutrophic and contains a high level of nutrients conducive to excessive algae growth.

Thermal well water is characterized by high concentrations of sodium and low concentrations of potassium. Some warm wells have dissolved solids concentrations as high as $4,000 \mathrm{mg} / 1$. However, the average total dissolved solids are around $900 \mathrm{mg} / \mathrm{l}$. Thermal water is generally potable. The waters are mildly basic with $\mathrm{pH}$ 's in the range 7.5 to 8.5 . (4) (5)

Data on the radioactivity associated with thermal waters in Klamath Falls is listed in a table on the following pages. Concentrations are generally well below established safety standards. The EPA drinking water standard for radium 226 is $5 \mathrm{pCi} / 1$. 


\begin{tabular}{|c|c|c|c|c|c|c|c|}
\hline County & Source & Location & $\begin{array}{l}\text { Sampling } \\
\text { Point Type }\end{array}$ & $\begin{array}{c}\text { Date } \\
\text { Sampled } \\
\end{array}$ & Water Use & $\begin{array}{c}\text { Temp. } \\
\mathrm{C} \\
\end{array}$ & $\mathrm{pH}$ \\
\hline $\begin{array}{l}\text { Klamath } \\
\text { Klamath } \\
\text { Klamath } \\
\text { Klamath }\end{array}$ & $\begin{array}{l}\text { CPI Storm Drain } \\
\text { K. Union High School } \\
\text { LDS Church } \\
\text { Lucas \& Howard Furniture }\end{array}$ & $\begin{array}{l}\text { Klamath Falls } \\
\text { Klamath Falls } \\
\text { Klamath Falls } \\
\text { Klamath Falls }\end{array}$ & $\begin{array}{l}\text { Cistern } \\
\text { Pumped Well } \\
\text { Pumped Well } \\
\text { Pumped Well }\end{array}$ & $\begin{array}{l}11 / 4 / 74 \\
11 / 5 / 74 \\
11 / 4 / 74 \\
11 / 4 / 74\end{array}$ & $\begin{array}{l}\text { Not in Use } \\
\text { Space Heating } \\
\text { Space Heating } \\
\text { Domestic } \\
\text { Non-Potable }\end{array}$ & $\begin{array}{l}71 \\
82 \\
56 \\
89\end{array}$ & $\begin{array}{l}7.60 \\
8.42\end{array}$ \\
\hline $\begin{array}{l}\text { Klamath } \\
\text { Klamath } \\
\text { K lamath } \\
\text { Klamath } \\
\text { K lamath } \\
\text { Klamath }\end{array}$ & $\begin{array}{l}\text { Mazama Mid High } \\
\text { Melo-Bel Dairy } \\
\text { OIT Well \#4 (cold) } \\
\text { OIT Well \#5 } \\
\text { O'Neill Grammar School } \\
\text { Liskey's Ranch }\end{array}$ & $\begin{array}{l}\text { Klamath Falls } \\
\text { Klamath Falls } \\
\text { Klamath Falls } \\
\text { Klamath Falls } \\
\text { Klamath Falls } \\
\text { T.40S., R. 9E., } \\
\text { S.34 }\end{array}$ & $\begin{array}{l}\text { Pumped Well } \\
\text { Pumped Well } \\
\text { Pumped Well } \\
\text { Pumped Well } \\
\text { Pumped Well } \\
\text { Pumped Well }\end{array}$ & $\begin{array}{l}11 / 5 / 74 \\
11 / 5 / 74 \\
11 / 4 / 74 \\
11 / 4 / 74 \\
11 / 5 / 74 \\
11 / 6 / 74\end{array}$ & $\begin{array}{l}\text { Space Heating } \\
\text { Pasteurization } \\
\text { Potable } \\
\text { Space Heating } \\
\text { Space Heating } \\
\text { Stock Watering }\end{array}$ & $\begin{array}{l}58 \\
81 \\
30 \\
89 \\
58 \\
85\end{array}$ & $\begin{array}{l}8.5 \\
8.38 \\
8.6 \\
7.81 \\
8.4\end{array}$ \\
\hline
\end{tabular}

\section{Location}

CPI Storm Drain

Klamath Union High School

LOS Church

Lucas \& Howard Furniture

Mazama Mid-High School

Melo-Bel Dairy

OIT Well \#4 (cold)

OIT Well \#5

O'Neill Grammar School

Liskey's Ranch

\begin{tabular}{|c|c|c|}
\hline Radon-222 & Radium-226 & Uranium-124 \\
\hline $72 \pm 17$ & $.061 \pm .051$ & $.018 \pm .017$ \\
\hline $\begin{array}{l}250 \pm 34 \\
160 \pm 23\end{array}$ & $.056 \pm .047$ & $.015 \pm .014$ \\
\hline $250 \pm 31$ & $\begin{array}{l}.24 \pm .077 \\
.13 \pm .059 \\
.11 \pm .060\end{array}$ & $\begin{array}{c}.028 \pm .028 \\
-- \\
--\end{array}$ \\
\hline $\begin{array}{r}200 \pm 28 \\
97 \pm 19\end{array}$ & $.073 \mp .069$ & $.13 \pm .053 \pm .031 \pm .022$ \\
\hline
\end{tabular}

0.013
$.032 \pm .020$
$.023 \pm .022$
$.013 \pm .012$
$.032 \pm .020$
0.0092
--
--
0.033
0.012

Thorium-232
0.017
0.017
0.015
0.022
0.016
0.010
$--$
0.015
0.014

Reported in units of picocuries per liter $(\mathrm{pC} i / 1)$

Source: Radioactivity Associated with Geothermal Waters in the Western U.S., 1976, EPA 
..BIOLOGICAL

..Dominant Flora:

The $\mathrm{Kl}$ amath Basin contains one of the most diverse aquatic plant communities in the Pacific Northwest.

Vegetation varies with elevation.

Pine Plateau: mixture of juniper-sage type and ponderosa-juniper association.

Juniper tablelands: Western jurijper, sagebrush, rabbit brush, bluegrass, Idaho fescue and cheatgrass are predominant.

Valleys: varies from agricultural crops to wet meadow plants and greasewood, sagebrush and weeds on the dryer sides.

\section{..Dominant Fauna:}

Wildlife in the Klamath Basin is diversified. There are about 67 species of mammals over 200 species of birds, and numerous species of fish, amphibians and reptiles in the area. Mule deer are the primary big game species.

One of the greatest concentrations of waterfow 1 in North America occurs in the Klamath Basin val leys. Approximately $80 \%$ of the waterfowl in the Pacific flyway pass through and spend time during the spring and fali migrations. Most species of North American waterfowl are present with geese, mallards and pintails comprising a high percentage of the total.

... Endangered Species:

Fauna: American Peregrine Falcon Brown pelican

Oregon Endangered or Threatened List:

Northern Bald eagle Northern spotted ow1 Western Snowy Plover Western Spotted frog 


\section{TRANSPORTATION AND UTILITIES}

\section{SITE: KLAMATH.FALLS KGRA}

..Utility of Energy Transmission Corridors and Facilities

Two $500 \mathrm{kv}$ lines running from the north crossing Beatty to Mal in via Bonanza and the north end of Bryant Mountain.

Pacific Power and Light Company has proposed construction of a $500 \mathrm{kv}$ line which will carry power from Midpoint, Idaho to the Mal in substation. The exact route of the line through the $K 1$ amath Basin has not been determined.

A natural gas pipeline parallels Highway 97.

Pacific Power and Light Company provides most of the electric service of the area from the Northwest Power Pool.

California Pacific Utilities Company supplies natural gas.

Four hydroelectric generation plants in the Klamath Basin: three below Upper Klanath Lake and one at Keno, combined capacity is 184,000 kwe.

..Transportation Corridors or Facilities:

Highway 97

Highway 66

Highway 39

Numerous urban streets, secondary roads and logging roads.

Rail: Southern Pacific

Burlington Northern

Oregon-California \& Eastern

Weyerhauser Railway (private)

Amtrak passenger service

Air: Klamath Falls Municipal Airport - Kingsley Field is jointly operated by the City of Klamath Falls and the U.S. Air Force. 


\section{POPULATION}

\section{SITE: KLAMATH FALLS KGRA}

..General Description of Population

The bulk of Klamath County's 1978 population of 58,700 people live in the Klamath Falls area. Klamath Falls proper has an estimated 1978 population of 18,300 . Approximately 55,000 people reside in the metropolitan area. Suburban and outlying communities include:

$\begin{array}{lr}\text { Altamont - population } & 15,746 \\ \text { Merrill - population } & 830 \\ \text { Bonanza - population } & 265\end{array}$

Midland

Henley

Olene

Dairy

Chiloquiin population 890 Modoc Point
Distance from Klamath Falls

$12 \mathrm{~km}$ south

$11 \mathrm{~km}$ southeast

$13 \mathrm{~km}$ southeast

$20 \mathrm{~km}$ east

$40 \mathrm{~km}$ north

$25 \mathrm{~km}$ northwest

..Economics

..Present Land Use:

The economy of the Klamath Basin is based heavily on natural resources. Primary industrial activities center around lumber and forest products which depend heavily on timber from public lands.

Secondary uses are: agriculture, livestock production and recreation.

The main agricultural crops are potatoes, feed grains and alfalfa.

Employment is heavily concentrated in the forest products industry. 


\section{Klamath Falls References}

Culver, G. G., Lund, J. W. and Svanevik, L. S., 1974, Klamath Falls Hot Water Well Study: Lawrence Livermore Laboratory, University of Cal ifornia, UCRL - 13614.

Leonard, A. R. and Harris, A. B., 1974, Ground Water in Selected Areas in the Klamath Basin, Oregon: Oregon State Engineer Ground Water Report 21.

Lienau, P. J., et. al., 1976, KImath Falls Geothermal Mini-Heating District Feasibility Study: ERDA and Idaho National Engineering Laboratory, Contract No. E (10-1)-1548.

Newcomb, R. C. and Hart, D. H., 1958, Preliminary Report on the Groundwater Resource of the Klamath River Basin, Oregon: U.S. Geological Survey Open File Report.

Peterson, N. V. and Groh, E. A., 1967, Geothermal Potential of the Klamath Falls Area, Oregon, A Preliminary Study: Ore Bin, V. 29, N. 11 .

Peterson, N. V. and McIntyre, J. B., 1970, The Reconnaissance Geology and Mineral Resources of Eastern Klamath County and Western Lake County, Oregon: Oregon Department of Geology and Mineral Industries Bulletin 66.

Purvine, W. D., 1974, Utilization of Geothermal Energy at Oregon Institute of Technology, Klamath Falls, Oregon, Multipurpose Use of Geothermal Energy: Oregon. Institute of Technology.

Reistad, G. M., Schmisseur, W. E., Shay, R. J., and Fitch, J. B., 1978, An Evaluation of Uses for Low to Intermediate Temperature Geothermal Fluids in the Klamath Basin, Oregon: Oregon State University Engineering Experiment Station, Bullet in No. 55.

Samell, E. A., 1976, Hydrologic Reconnaissance of the Geothermal Area near Klamath Falls, Oregon: U.S. Geological Survey Open File Report WRI 76-167.

Sass, J. H. and Sammel1, E. A., 1976, Heat Flow Data and The ir Relation to Observed Geothermal Phenomena near Klamath Falls, Oregon: Journal of Geophysical Research, V. 81, N. 26.

Storey, David M, 1974, Geothermal Drilling in Klamath Falls, Oregon, Multipurpose Use of Geothermal Energy: Oregon Institute of Technology. 
U.S. Geological Survey, Water Supply, 1976, Water Resource Data for Oregon-Water Year 1975: U.S. Geological Survey Water Data Report OR-75-1.

Walker, G. W., 1963, Reconnanissance Geological Map of the Eastern Half of the Klamath Falls (AMS) Quadrangle, Lake Lane and Klamath Counties, Oregon: U.S. Geological Survey Mineral Investigations Field Studies Map MF-260. 

SITE: LAKEVIEW KGRA, OREGON 







\section{Lakeview KGRA}

Lakeview is situated on the eastern margin of Goose Lake Valley in south-central Oregon. The U.S.G.S. designated KGRA covers 12,165 acres of mostly privately-owned land centered around the town of Lakeview in T.38 and 39S., R.20E., Willamette Meridian. Lakeview is the service center and county seat for Lake County. It is also the population center with about 3,000 residents.

The landscape is characteristic of the Basin and Range province: north-trending grabens separated by fault block mountains. Lakeview is in the Goose Lake graben which contains intermittent Goose Lake. Fluctuations in the lake level through time have covered much of the basin with alluvium. Moving away from the valley, the topography varies from flat playas to rolling lava plateus and steep fault scarps. The tectonic and volcanic forces which contributed to the development of the landforms are favorable indicators of a geothermal resource.

The geothermal potential of the Lakeview area is further evidenced by two groups of hot springs. The largest group of thermal springs is located along a major fault scarp on the eastern margin of Goose Lake graben about $4 \mathrm{~km}$ north of Lakeview. These springs have a surface temperature of $96^{\circ} \mathrm{C}$, boiling point for the altitude, and a flow of approximately $2,300 \mathrm{Ipm}$. Geochemical thermometry indicates a minimum estimated reservoir temperature of $160^{\circ} \mathrm{C}$. Along the same zone about $3.6 \mathrm{~km}$ south of town, is a second group of hot springs with an average temperature of $88^{\circ} \mathrm{C}$ and a geochemically determined minimum reservoir temperature of $153^{\circ} \mathrm{C}$ (U.S.G.S. 726). Between these two groups of springs, shallow water wells have warm temperatures.

The alignment of the hot springs suggest that they are fault controlled. Convective forces that transport heat along the fault zones from deep magma reserves may be the heat source. Geothermal gradient drilling has demonstrated high heat flow values in Lakeview area wells. These measurements support the theory that water in the alluvial deposits is warmed by heat flowing through fractured volcanics and along fault zones.

In the area of Hunters Hot Spring, Meyer and Hook (1978) suggest that thermal waters have precipitated dissolved silica as they cooled which formed a cap rock. This silica cap is about $46 \mathrm{~m}$ (150 ft.) deep and $61 \mathrm{~m}$. (200 ft.) thick. Beneath the seal, water encountered is likely to be above the boiling point. It can be expected that the potential resource would be found at shallow depths. 
Geologic and geophysical investigations indicate that there is a substantial resource in the Lakeview area for direct use applications of geothermal energy. The hot spring area north of town appears to have the best potential because of high temperatures and good flow rates. $A$ shallow high temperature resource near a population center which has taken an active interest in geothermal development, further supports the evidence of high potential for geothermal utilization in the Lakeview area.

The Town of Lakeview has taken the lead to expand the use of this local energy resource by studying the feasibility of a district heating system in cooperation with Northwest Natural Gas, a private utility. Franchise rights have been awarded to the utility to lay pipelines and supply hot water to customers. The utility's economic analysis report pointed out the need for large energy consumers in addition to residential customers to make the project cost effective.

Industries based on the local natural resources are likely candidates for geothermal commercialization. Potential uses include: alfalfa and grain dehydration, commerical refrigeration, greenhouses, geothermal feed-lots and meat processing facilities, methane production, and wood-waste processing for pelletization or fermentation and distillation processes.

Use of geothermal resources for such activities would enchance the economic stablity of the area. The feed-lot and processing operation appears particularly attractive in this regard. Cattle are now. trucked to California for processing. Development of a geothermal meat processing facility in Lakeview would cut transportation costs and retain more of the economic benefits in Lake County.

The mills in Lakeview burn wood wastes to produce steam for kiln drying of lumber. It appears, however, that adequate supplies of wood wastes are available to justify a geothermally assisted pelletization process.

Such industrial uses could be concentrated in the area zoned for an industrial park north of Lakeview near the hot springs. Thermal waters could supply the process needs of the industrial complex and be piped to Lakeview for space heating in residential and commerical buildings.

Several factors are impeding the rapid development of geothermal resources in Lakeview. Foremost is the need for reservoir boundary definition and confirmation. This need could be satisfied with a carefully planned gradient hole drilling program. The lack of financial incentives to encourage industries to convert to geothermal energy is also hampering development. 
When these factors have been reconciled, industrial development is likely to be stimulated by the availability of geothermal energy. To facilitate the accompanying growth, it will be necessary to expand the city water system. Lakeview is currently taking measures to accomplish this task.

Overall, the apparent high temperature shallow resource and the proximity to a population center combine to give the Lakeview area a bright outlook for non-electrical geothermal development in the near term. 
SITE DATA SUMMARY

SITE: LAKEVIEW KGRA, Oregon

..Physical Reservoir Data

.. Temperature ${ }^{\circ} \mathrm{C}$

Surface: $96^{\circ} \mathrm{C}$

Subsurface: $160^{\circ} \mathrm{C}$

(1)

..Total Dissolved Solids (PPM): Hunters Hot Spring-925 ppm

Barry Ranch Hot Spring-905 ppm

..Type of Overlaying Rock: Andesite, Andesitic tuff, tuff breccias, and basalt.

... Est imated Depth to Top of Reservoir (meters): $1000 \mathrm{~m}$.

..Site Land Status - Majority of land is in private ownership.

FED.

12,165

(KGRA)

STATE PRIVATE

Total Acres

Total Acres Leased

0

0

Unknown

..Geothermal Development Status:

Geothermal waters supply heating to commercial greenhouses totaling 2,800 sq. $\mathrm{ft}$. and covering $3 / 4$ acre.

Several homes and a motel, on the north end of Lakeview, are geo-heated.

The town is studying the possibility of establishing a district heating system.

A small worm business is planning for geothermal soil warming.

.. Local and State Attitude Toward Geothermal Development:

Locals appear receptive to geothermal development. The town government is working with a private utility investigating the feasibility of a district heating system. Local government has also established a Geothermal Council. A considerable number of private land owners have leased their geothermal rights to development companies.

..Land Use and Population:

The region is sparsely populated, but a concentration is situated around the town of Lakeview.

Primary economic activities include; urban services and government, timber and wood products, livestock raising and agriculture. 


\section{SITE LOCATION AND PHYSICAL DESCRIPTION}

SITE: LAKEVIEW KGRA

..Latitude: $42^{\circ} 12^{1} \mathrm{~N}$

..Longitude: $120^{\circ} 21.6^{\prime} \mathrm{W}$

..Rectilinear: Secs. 32,33, T.38S., R.20E., W.M.;

Secs. $3-5,8-10,15-17,20-22,27-29,33,34$, T.39S., R.20E.

.. County: Lake

.Adjacent Counties: Klamath, Harney, Crook, Deschutes, Woshoe, Nv.

..Map Reference: USGS Topographic-Lakeview NE 1:24,000;

AMS-K I amath Fal Is, OR-Cal. 1:250,000

.. Topography:

Lakeview lies in the Basin and Range Province at 1,607 meters, the highest town in Oregon. The area is dissected by two prominent sets of faults. Vertical displacements along the faults have resulted in north-trending grabens bordered by mountains. Lakeview is within the Goose Lake graben. The topography varies from flat playas to gently rolling lava plateus to steep, high eroded landforms resulting from faulting, eruptive events, and erosion.

..Present Land Use:

Predominately urban uses, 1ivestock grazing, grain production, and timber resource land at higher elevations.

..Future Land Use Plans:

Further growth is dependent on expansion of the city water system.

.. Historical/Archaeological Significance:

In 1923, Dr. H. A. Kelty and associates constructed a sanatorium at Hunter's Hot Springs. The facility is currently operated as a motel. Archaeological significance is unknown. Several historic buildings in Lakeview have been placed on the National Register. 


\section{GEOLOGICAL/GEOPHYSICAL DESCRIPTION}

\section{..Geologic Description:}

Geology of the Lakeview area is taken from Peterson and McIntyre (1970).

The oldest rocks exposed in the Lakeview area are 01 igocene-Miocene andesitic tuffs, tuff breccias, tuffaceous sandstones with local flows of andesite and basait, mudstones and conglomerates.

This unit is unconformably overlain by a thick sequence composed of rhyolitic and dacitic tuffs, tuffaceous sediments, palagonite tuff, and minor basalt and andesitic flows. The unit is late Miocene to early Pliocene in age.

Extensive porphyritic olivine basalt flows were extruded unconformably upon the rhyolitic and dacitic deposits during the mid-Pliocene. Thickness of the flows is approximately $61 \mathrm{~m}$. (200 ft.).

Overlying the basalt flows in the basins is a Pleistocene unit consisting of fluvial terrace, and diatomaceous and tuffaceous lacustrine sediments ranging from silts to conglomerates. This unit is locally overlain by Quaternary alluvial and playa deposits.

Lakeview is within the Basin and Range province which is dissected by two prominent fault sets. The sets are normal faults trending N.0-200E. and N.20-350 W. Vertical displacements along these faults have resulted in downthrown north-trending grabens bounded by mountains. Goose Lake is one of the larger grabens in the region.

The northwest-trending faulting is thought to have begun in the Pliocene and ended in the Pleistocene. (Peterson and McIntyre, 1970). The fault group is closely spaced and has a vertical displacement of generally less than $152 \mathrm{~m}$. (500 ft.). Movement along the faults appears to have occurred following the disposition of lacustrine sediments.

The north-to-northeast-trending faults displace the northwest-trending set. Peterson and McIntyre (1970) have suggested that faulting started in the early Pleistocene and continued to the Quaternary. The group is characterized by normal faults with dip-slip movement and vertical displacement up to $1,524 \mathrm{~m} .(5,000 \mathrm{ft}$.$) . These faults form the large horsts$ and grabens of the area. 
An anticlinal structure of regional extent parallels the northwest-trending fault set. It is thought to be older than or contemporaneous with the northwest-trending fault zone. Faulting appears to have occurred after the deposition of lacustrine sediments which exhibit evidence of folding. (Peterson and McIntyre, 1970). (23) (24) (18)

- Geophysical Summary:

Regional gravity maps by Berg and Thiruvathukal (1967) indicate a $30 \mathrm{mgal}$ negative anomaly at the northern end of Goose Lake. (17)

In 1973 Gulf $0 i 1$ Company drilled a $1,658 \mathrm{~m} .(5,440 \mathrm{ft}$.$) deep$ gradient hole in an area between the northern and southern groups of hot springs. The drilling encountered lost circulation at $1,584 \mathrm{~m}$. $(5,200 \mathrm{ft}$.$) and the well was abandoned$ in November 1973. The measured gradient was $40^{\circ} \mathrm{C} / \mathrm{km}$, considerably below the average gradient of $600 \mathrm{c} / \mathrm{km}$ for the Basin and Range province. (25)

The Humble 011 Company drilled a $2,915 \mathrm{~m} .(9,564 \mathrm{ft}$.$) oil test$ well in 1961. The hole is located about $3 \mathrm{~km}$ southeast of Barry Ranch Hot Spring. The bottom hole temperature measured shortly after drilling ceased was $140^{\circ} \mathrm{C}$. This temperature is close to the silicia geochemically determined reservoir temperature of $153^{\circ} \mathrm{C}$ for Barry Ranch Hot Spring. (26)

Heat flow and geothermal gradients have been measured in shallow existing wells in the vicinity of Lakeview, but outside the boundaries of the KGRA. The Thomas Creek area which 1 ies in the mountains northwest of Lakeview has been identified as a geothermal anomaly. The average for three gradient measurements in an area of rhyolite domes was $123^{\circ} \mathrm{c} / \mathrm{km}$, well above the $60^{\circ} \mathrm{c} / \mathrm{km}$ regional average. The average heat flow was 3 Heat Flow Unit (HFU)*.

The nearest gradient well to Lakeview is situated east of town near Rogger Peak. The measured gradient was $390 \mathrm{c} / \mathrm{km}$, but was uncorrected for topography. (19) (27)

Uranium exploration drilling conducted during the fall of 1978 may provide more information on the geothermal resources in the Lakeview area.

* One heat flow unit is equal to $1 \times 10^{-6} \mathrm{cal} / \mathrm{cm}^{2} / \mathrm{s}$ 


\section{RESERVOIR CHARACTER ISTICS}

SITE: LAKEVIEW KGRA

..Reservoir Temperature

.. Surface: $96^{\circ} \mathrm{C}$

..Subsurface: $160^{\circ} \mathrm{C}$

..Geochemical

$$
\begin{array}{r}
\mathrm{SiO}_{2}: 157^{\circ} \mathrm{C} \\
\mathrm{Na}-\mathrm{K}-\mathrm{Ca}: 143^{\circ} \mathrm{C}
\end{array}
$$

..Flow Rates: Hunters Hot Spring $-2300 \mathrm{1pm}$

..pH: 7.77

..Total Dissolved Solids:

Hunters Hot Spring - $925 \mathrm{ppm}$

Barry Ranch Hot Spring - 905 ppm (3)

...Fluid Chemistry:

Hunters Hot Spring has a surface temperature of $94^{\circ} \mathrm{C}$ which is the boiling point for the altitude and a flow of approximately 2,300 lpm. A geyser known as "0ld Perpetual" erupts from a drilled well at Hunters Lodge about three times a minute reaching a height of 15-22 meters.

At Hunter Hot Spring there are 12 main orifices in the large thermal area. This includes an artesian we $11.8 \mathrm{~km}$ northwest; $61 \mathrm{~m}$. deep of $120 \mathrm{gpm}$ of boiling water. Another well drilled in 1960 to $198 \mathrm{~m}$. is now used for heating a greenhouse complex. Several other shallow wells in the area have temperatures in the $88-93^{\circ} \mathrm{C}$ range.

Other water wells in and around Lakeview report warm water.

Chemical analysis and information on selected hot springs is presented on the following page.

..Estimated Reservoir Heat Content:

$1.4 \times 1018 /$ Cal (1) DOE/DGE estimates 50 MWe non-electrical use USGS estimates 110 MWe (15)

..Subsurface Area of Reservoir: $8 \mathrm{~km}^{2}$ estimated 


\section{CHEMICAL ANALYSES OF THERMAL WATER}

\begin{tabular}{|c|c|c|c|c|}
\hline & $\begin{array}{c}\text { Hunter } \\
\text { Hot Spring } \\
\text { (units mg/1) } \\
\end{array}$ & $\begin{array}{c}\text { Hunter } \\
\text { Hot Spring } \\
\text { (Units ppm) }\end{array}$ & $\begin{array}{c}\text { Barry Ranch } \\
\text { Hot Spring } \\
\text { (units mg/1) } \\
\end{array}$ & $\begin{array}{c}\text { Leo Hanks } \\
\text { Spring } \\
\text { (units ppm) }\end{array}$ \\
\hline $\begin{array}{l}\text { Point of Collection } \\
\text { Specific Conductance (micromhos) } \\
\text { Silica } \\
\text { Calcium } \\
\text { Magnesium } \\
\text { Sodium } \\
\text { Potassium } \\
\text { Lithium } \\
\text { Bicarbonate } \\
\text { Carbonate } \\
\text { Sulfate } \\
\text { Chloride } \\
\text { Floride } \\
\text { Boron } \\
\text { Temperature (oC) } \\
\text { pH } \\
\text { Flow } \\
\text { Total Dissolved Solids }\end{array}$ & $\begin{array}{c}\text { spring } \\
1,120 \\
140 \\
13 \\
0.1 \\
210 \\
8.5 \\
.15 \\
79 \\
1 \\
260 \\
120 \\
4.4 \\
6.9 \\
96 \\
7.77 \\
23007 \mathrm{pm} \\
925 \mathrm{ppm}\end{array}$ & $\begin{array}{c}\text { pool } \\
1,140 \\
140 \\
8 \\
2.4 \\
208 \\
10 \\
64 \\
5 \\
258 \\
120 \\
4.5 \\
7.1 \\
86 \\
8.4 \\
1921 \mathrm{pm} \\
821 \mathrm{ppm}\end{array}$ & $\begin{array}{l}\text { spring } \\
1,370 \\
130 \\
8.8 \\
0.1 \\
280 \\
9.0 \\
.15 \\
232 \\
2 \\
240 \\
170 \\
5.4 \\
11.2 \\
88 \\
7.76 \\
2001 \mathrm{pm} \\
905 \mathrm{ppm}\end{array}$ & $\begin{array}{c}\text { spring } \\
66 \\
15 \\
0.4 \\
152 \\
2.2 \\
84 \\
152 \\
99 \\
3.1 \\
7 \\
69 \\
7.7 \\
531 \mathrm{ppm}\end{array}$ \\
\hline
\end{tabular}




\section{HOT SPRINGS IN THE LAKEVIEW AREA}

\begin{tabular}{|c|c|c|c|c|c|}
\hline Name & Section & Township & Range & $\begin{array}{c}\text { Maximum } \\
\text { Temperature }{ }^{\circ} \mathrm{C}\left({ }^{\circ} \mathrm{F}\right)\end{array}$ & Notes \\
\hline Bean Hot Spring & 11 & $37 S$. & $20 \mathrm{E}$ & $20(59)$ & $\therefore$ \\
\hline White Rock Hot Spring & 26 & $36 S$ & $20 \mathrm{E}$ & $20(71)$ & 2 springs in 1 \\
\hline Hammers ley Hot Spring & 22 & $38 S$ & $19 E$. & $16(60)$ & $1,000 \mathrm{gpm}$ \\
\hline $\begin{array}{l}\text { City of Lakeview } \\
\text { (Leo Hanks Spring) }\end{array}$ & 16 & $39 S$. & $20 \mathrm{E}$ & $26(79)$ & \\
\hline Leithead Hot Spring & 27 & $39 S$. & $20 E$. & $72(162)$ & $50 \mathrm{gpm}$, strong $\mathrm{H}_{2}$ Sodor \\
\hline Barry Hot Spring & 34 & 395. & $20 \mathrm{E}$. & $85(185)$ & $50 \mathrm{gpm}$, strong $\mathrm{H}_{2}$ Sodor \\
\hline Hunters Hot Spring & 4 & $39 S$. & $20 \mathrm{E}$ & $94(202)$ & \\
\hline
\end{tabular}

Source: Thermal Springs \& Wells in Oregon, Bowen and Peterson, 1970 
LAND OWNERSHIP AND LEASING

SITE: LAKEVIEW KGRA

TOTAL AREA

FEDERAL

PRIVATE

(Acres)

(Acres) (Acres)

..Land Ownership - KGRA

12,165 (13)

0

12,165

-. Land Leased

total

acreage

unknown

..Highest Prices Leases

(Dollars/Acre) unknown

- Lessee

total

Standard 0 i $1 \mathrm{Co}$.

acreage

Getty 0 il

unknown

LVO Corp.

Magma Power

Union 011

Gulf 0il

Hunt $0 i 1$

. Tentative Lease Sale Dates:

N/A - private land

.. Summary of Leasing Status and Needs:

Exact location and total acreage of leased private land are unknown.

Most of the area in and around Lakeview is patented land. The plat map for T.39S., R.20E. shows two very small parcels of land which the U.S. Government may have retained mineral rights.

Gulf 0 il holds the majority of leases in the area. 


\section{GEOTHERMAL DEVELOPMENT STATUS}

SITE: LAKEVIEW, KGRA

..Present Development Status:

Commercial greenhouses are heated with geothermal water. Area of the houses is approximately 2,800 sq. ft. covering $3 / 4$ acre.

Tomatoes have been grown, but tree seedlings and bedding plants are being raised now.

A well drilled in 1923 produced a geyser which still spouts 15-22 meters of thermal water at a local motel. The facility is heated with hot water from another well.

Space heating for less than 10 homes is provided by geothermal sources.

A municipal warm water well at the city swimming pool is used to fill the pool occasionally.

..Projected or Planned Development:

A district heating system for industrial processing and residential space heating has been proposed.

Soil warming using geothermal water is planned for a small worm business. 


\section{INSTITUTIONAL CONSIDERATIONS}

SITE: LAKEVIEW KGRA

..Institutional Requirements:

Geothermal exploration and development may require a conditional use permit from the county.

..Agency and Public Attitudes:

Local attitudes appear favorable towards geothermal development. The town government has established a Geothermal Council, and is investigating the possibility of setting up a district heating system.

..Status of Requirements (i.e., EIA/EIS Requirements):

No environmental analyses specifically addressing geothermal resources have been completed.

The BLM-Lakeview District plans to compile on EAR to cover leasing in the Goose Lake Valley.

The Fremont National Forest will complete an EAR or EIS for leasing on federal land. The project is scheduled to begin in 1979. (22) 


\section{ENVIRONMENTAL FACTORS}

SITE: LAKEVIEW, KGRA

..CLIMATE Semiarid

..Prevailing Winds: Southwest

..Precipitation (Annual): $41 \mathrm{~cm}$.

. Average Temperature $7.8^{\circ} \mathrm{C}\left(46.2^{\circ} \mathrm{F}\right)$

Minimum: $\quad-2.3^{\circ} \mathrm{C}\left(278^{\circ} \mathrm{F}\right)$

Maximum: $\quad 19.2^{\circ} \mathrm{C}\left(66.6^{\circ} \mathrm{F}\right)$

..Degree Days (Annual): 7069

..Relative Humidity: low

..AIR QUALITY:

Generally good air quality conditions. Temporary dust storms occur when strong winds transport large amounts of alkali dust from Goose and Summer Lake areas. Smoke from lumber operations causes smog conditions during inversions.

..WATER QUALITY:

Data on the radioactivity associated with thermal water in the Lakeview area is listed on the following page. Concentrations are generally well below established safety standards. The EPA drinking water standard for radium 226 is $5 \mathrm{pCi} / 1$. 
RADIOACTIVITY ASSOCIATED WITH GEOTHERMAL WATERS IN LAKEVIEW

\begin{tabular}{|c|c|c|c|c|c|c|c|}
\hline County & Source & Location & $\begin{array}{l}\text { Sampling } \\
\text { Point Type }\end{array}$ & $\begin{array}{l}\text { Date } \\
\text { Sampled }\end{array}$ & Water Use & ${ }_{O C}^{\text {Temp }}$ & $\mathrm{pH}$ \\
\hline Lake & Desert Farms, Inc. & Lakeview & Pumped Well 1 & $11 / 5 / 74$ & Space Heating & 60 & \\
\hline Lake & Hunter's Lodge & Lakeview & Spring & $11 / 5 / 74$ & Space Heating & 93 & 8.5 \\
\hline Lake & Barry's Ranch & $\begin{array}{l}\text { T. } 40 \mathrm{~S}_{0}, \\
\text { R. } 20 \mathrm{E}_{0}, \\
S_{.11}\end{array}$ & Spring & $11 / 5 / 74$ & Stock Watering & 74 & 8.27 \\
\hline
\end{tabular}

\section{Location}

Desert Farms, In

Hunter's Lodge

Barry's Ranch

\section{Radon-222}

$260 \pm 28$

$55 \pm 14$

$--$
Radium-226

$.061 \pm .051$

$.13 \pm .064$

$.072 \pm .043$
Uranium-234

$.017 \pm .014$

0.019

0.015
Uranium-238

0.0097

0.014

0.0079
Thorium-230

0.019

0.027

0.017

Thor ium-232

0.019

0.013

0.017

Reported in units of picocuries per liter (pCi/1)

Source: Radioactivity Associated with Geothermal Waters in the Western U.S., U.S. EPA Office of Radiation Programs, 1976. 
. BIOLOGICAL

.. Dominant Flora:

Vegetation in the valley consists primarily of sagebrush and bunchgrass.

Higher elevations, outside the KGRA, support forests of Ponderosa pine and lodge pole pine with less abundant stands of Douglas fir, various true firs and white pine. (14)

..Dominant Fauna:

The following selected anaimals are found in the vicinity of Lakeview: Mule deer, antelope, Rocky Mountain elk, cougar, coyotes, beavers, bobcats, rodents, black bear, chukars, grouse, and quail.

Waterfow1 - Canadian geese, mallards, western grebes, teals, gadwalls.

Shorebirds - White pelican, sandhill crane, great blue heron, gulls, and American avocet.

The area is used extensively for deer and waterfowl hunting. (14)

..Endangered Species

Flora: Unknown.

Fauna: No endangered species have been identified.

State of Oregon Treatened Species: Northern bald eagle (Haliaeetus leucocephalus) 


\section{TRANSPORTATION AND UTILITIES}

\section{SITE: LAKEVIEW KGRA}

..Utility or Energy Transmission Corridors and Facilities

Surprise Valley Electrical Company maintains a $69 \mathrm{kv}$ line which runs from Lakeview to the substation at Paisley. (20)

Pacific Power and Light Company owns a $69 \mathrm{Kv}$ line running east from the Klamath Falls - Chiloquin area through Lakeview, then south into California. (20)

A natural gas pipeline parallels Highway 97.

Electrical service in the urban area is supplied by the Pacific Power and Light Company. Surprise Valley Electrical Company has been allocated to serve rural areas.

..Transportation Corridors or Facilities:

Highway 395

Route 140

Highway 31

Numerous streets in Lakeview.

A branch of the Southern Pacific Railroad terminates in Lakeview, although at the turn of the century the line was designed to extend to Bend. The line travels south to Alturas where it connects with a main line. 


\section{POPULATION}

SITE: LAKEVIEW KGRA

..General Description of Population

Lakeview is the population center and county seat for Lake

County. Estimated population for Lakeview is 3,000. A majority live in the Lakeview urban area, but others live on ranches scattered in the outlying areas.

Surrounding settlements include; Paisley (population 300 ) $58 \mathrm{~km}$ north of Lakeview and Klamath Falls (population 18,300) $144 \mathrm{~km}$ west.

...Economics

...Present Land Use:

Several lumber mills are situated in Lakeview which depend on timber from the nearby Fremont National Forest. Lakeview is the service center for Lake County and headquarters for several federal agencies district offices.

Livestock raising, including grazing and grain production is the second most economically important industry in Lake County. (See the following table for 1977 Gross Farm Sales).

Other activities include recreation and mining (currently uranium exploration).

..Future Land Use:

An expanded city water system is necessary to facilitate further growth.

A private company is converting a uranium processing plant into a lumber mill north of Lakeview. 


\section{Annual Gross Farm Sales}

1977 Lake County

Product

Hay and silage

Grain

Grass and legume seed

Speciality products

All crops

Cattle and calves

Dairy

Eggs and poultry

Misc. animals

A11 livestock and products
Total in Thousands of Dollars

1,647

701

396

560

3,304

8,890

80

1

163

9,134

Source: Oregon State University, Agricultural Extension Economic Information 


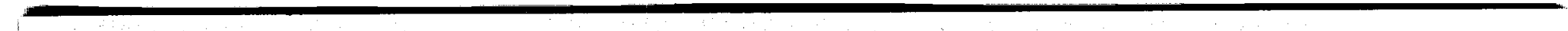

SITE: SUMMER LAKE HOT SPRING KGRA 


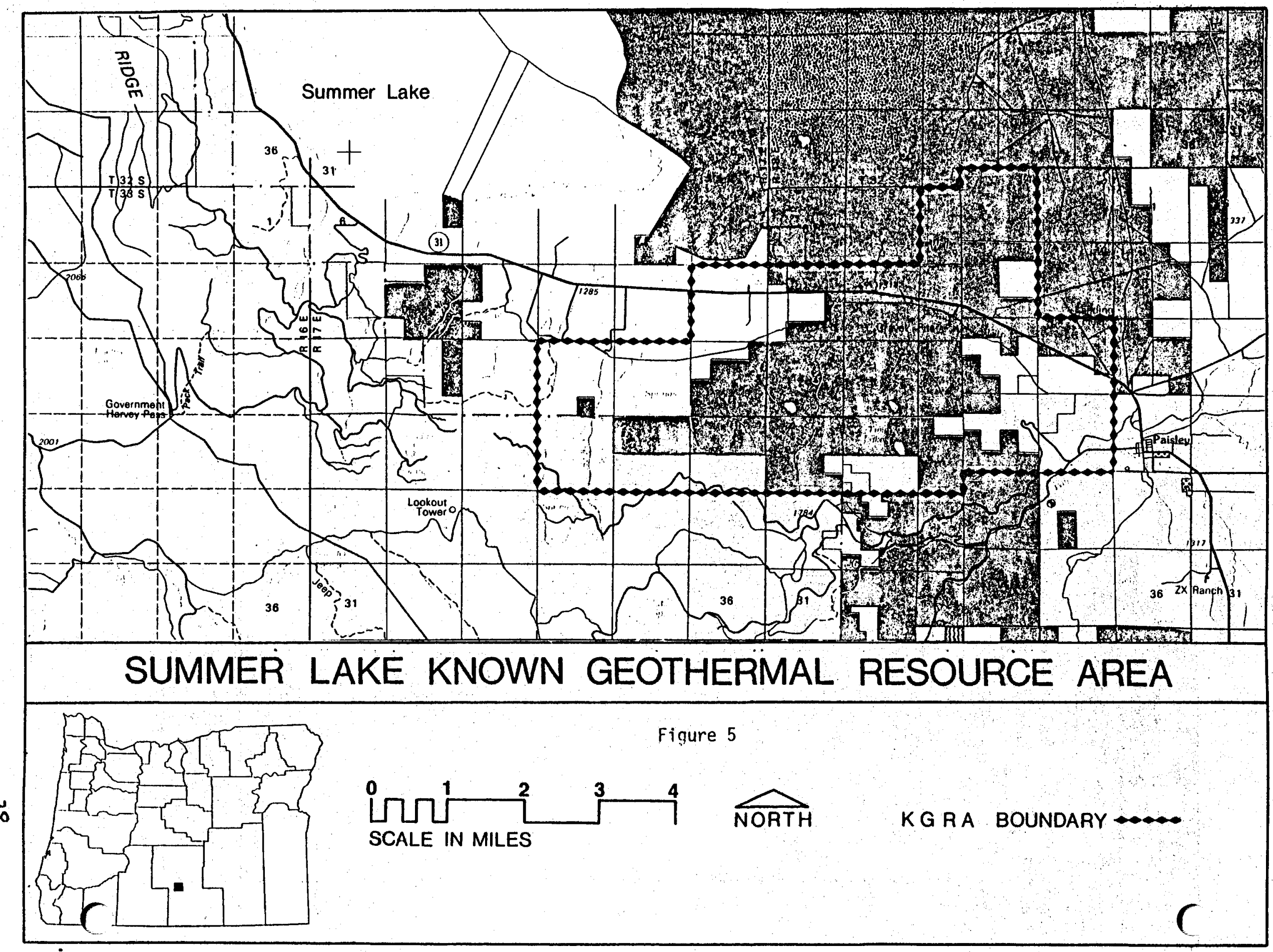




\section{SUMMER LAKE KGRA}

The Summer Lake KGRA is situated approximately $10 \mathrm{~km}$ northwest of Paisley in south-central Oregon. Competitive geothermal leasing has been designated for public land in T.335., R.17 and 18E, Willamette Meridian by the U.S. Geological Survey. These lands are administered by the Lakeview District Office of the Bureau of Land Management.

The identified geothermal resource area is part of the Summer Lake basin which is a complex Basin and Range type graben. Abert Rim to the east and Winter Ridge to the west are fault block mountains forming the margains of the Summer Lake Valley. The area is an extension of the Goose Lake graben which lies to the south. The KGRA lies southeast of Summer Lake, a large playa lake which is often pumped dry in the summer months to maximize potential for irrigation. Summer Lake is quite saline which restricts vegetative growth to salt tolerant species in the area adjacent to the lake. Otherwise the predominate vegetation is sagebrush in the basin and juniper association at higher elevations.

The land around Summer Lake is used almost exclusively for livestock raising. Both private and public land are heavily used for grazing. Agricultural activities are limited to grains and related crops to provide feed for livestock operations. Other land uses in the area include the small communities of Summer Lake and Paisley; and the Summer Lake Wild ife Management Area which is maintained for migratory waterfowl habitat.

The basin contains numerous hot springs occurring in two general groups: several warm springs at the northern end of Summer Lake graben, and a southern group consisting of Summer Lake Hot Springs and warm groundwater wells near Paisley. Summer Lake springs have the highest temperature at $43^{\circ} \mathrm{C}$ surface and an estimated minimum reservoir temperature of $140^{\circ} \mathrm{C}$.

Warm water in the southern group is also encountered in groundwater wells near Paisley. Most notably is the Paisley Highway well located about $10 \mathrm{~km}$ west of the town near one of the faults along the edge of the graben. The well has a surface temperature of $32^{\circ} \mathrm{C}$ and a flow of approximately $75 \mathrm{lpm}$. Numerous other water wells in the Paisley area have above normal temperatures. 
Many of the springs in the northern group lie in the Summer Lake Wildlife Management Area. Temperatures of the springs vary from $13^{\circ}-24^{\circ} \mathrm{C}$. These warm temperatures are augmented by large volumes of discharge. Ana River Springs is the largest, flowing at 11,888 liters per minute with a surface temperature of $19{ }^{\circ} \mathrm{C}$. This spring is one of the largest in the U.S. The low temperatures and high flow rates of the springs in the northern group could suggest higher temperature geothermal water mixing with colder groundwater.

These surface manifestations indicate a potential for geothermal resource development. This opportunity has been recognized by companies such as Chevron and Supron Energy Corporation who hold competitive leases on more than half the KGRA. However, these leases appear to be speculative in nature since minimal to no exploration activities have been carried out.

Clearly there is a need to gain a better understanding of the Summer Lake geothermal resource before realistic plans for utilization can be postulated. Considering that environmental reviews have already approved areas for leasing and given the favorable local attitudes towards geothermal development, exploration activities could be carried out in the near term without undue hindrance.

It is possible that test drilling may uncover new information indicating that the Summer Lake area has potential for electrical generation. However, at this point, the identified temperature range restricts discussions of potential uses to direct applications. Examples of energy dependent uses which are capable of being supplied by a $140^{\circ} \mathrm{C}$ resource include: space heating, greenhousing, aquaculture, lumber drying, refrigeration, drying of organic materials, extraction of salts by evaporation and crystalization, and various other industrial processes.

Yet, even without knowing the true nature of the resource, these applications are restricted by the general lack of population in the Summer Lake area. Given the existing development, geothermal resources could best be utilized for kiln drying of lumber, grain drying, limited space heating, and greenhouses. If the resource proves to be commercially valuable, industrial users such as lumber mills, feed lots, facilities for processing diatomite, and large scale greenhouse operations could be lured into the area by the availability of inexpensive geo-heat. But, first, the resource must be defined. 


\section{SITE DATA SUMMARY}

SITE: SUMMER LAKE HOT SPRING KGRA

. Physicar Reservoir Data

.. Temperature ${ }^{\circ} \mathrm{C}$

Surface: $43^{\circ} \mathrm{C}$

Subsurface: $140^{\circ} \mathrm{C}$

. Total Dissolved Solids (PPM): $1120 \mathrm{ppm}$

..Type of Overlaying Rock: Al luvium, Andesite, Andesitic

Tuff-Breccia

..Estimated Depth to Top of Reservoir (meters): $1.5 \mathrm{~km}$

..Site Land Status

\section{FEDERAL}

Approx. 11,460

7,521

STATE

Total KGRA Acres - 13,631

Total KGRA Acres Leased

- Geothermal Development Status:

Space heating of two residences and a swimming pool at Summer Lake Hot Springs.

. Local and State Attitude Toward Geothermal Development:

Most residents favor the leasing of federal lands.

Many private land owners have leased the geothermal rights of their property.

.. Land Use and Popultion:

Limited population. Primary land uses include 1iverstock, grazing, hay and alfalfa production and recreation. 
SITE LOCATION AND PHYSICAL DESCRIPTION

SITE: SUMMER LAKE HOT SPRING KGRA

. Latitude: $42043^{\prime} \mathrm{N}$

..Longitude: $120038^{\prime} \mathrm{W}$

..Rectilinear: Sec. 12-15, 22-24, T.33S., R.17E., W.M.

Sec. $3,4,7-10,14-23$, T.33S., R.18E.

.. County: Lake

..Adjacent Counties: Klamath, Deschutes, Harney, Crook

..Map Reference: U.S.G.S.-Summer Lake, Fremont Point, Slide. Mtn. $1: 24,000$

AMS - Klamath Falls, Ore.-Ca1. 1:250,000

. Topography

The Summer Lake basin is a complex. graben at the northern extreme of the Basin and Range province. The al luvium filled valley is part of the broad composite graben that contains the Lake Abert basin to the east and the northern extension of the Goose Lake graben to the south. The basins are separated by plateus of fault block mountains. Elevation at Summer Lake is $1,306 \mathrm{~m}(4,285 \mathrm{ft}$.$) . Predominate vegetative cover is desert$ shrub.

..Present Land Use:

Primarily livestock grazing, agriculture and recreation.

Summer Lake Wildlife Management Area on the north end of Summer Lake (outside the KGRA) is maintained for migratory waterfowl habitat.

U.S. Geological Survey has classified the area as being prospectively valuable for oil and gas.

..Aesthetics:

The Environmental Analysis Record classifies the KGRA as having low scenic quality. However, the area is within $3 \mathrm{~km}$ of an area with primitive values and meets the minimum criteria of the 1964 Wilderness Act. (28) 


\section{..Historical/Archaeological Significance:}

The Summer Lake area contains many archaeological sites. Four known sites and two potential sites have been identified within the KGRA. The sites appear to be small temporary hunting camps. One site is tenatively dated between 4500-2500 years ago while the others date between 2500-500 years ago. A complete inventory and evaluation of archaeological sites will be required as stipulations to geothermal leases.

..Geologic Description:

The geology of the Summer Lake basin has been summarized in the Environmental Analysis Report:

"Summer Lake lies at the northern extreme of the Bas in and Range Province and is characterized by a broad al luviated graben between fault sets. The graben is part of the broad composite graben that contains the Lake Abert bas in to the east and the northern extension of the Goose Lake graben to the south (Donath, 1962).

The primary structural feature is the fault forming Winter Ridge on the western edge of the basin. This fault appears to have a nearby vertical dip and a displacement in excess of $5,000 \mathrm{ft}$. (Peterson and McIntyre, 1970). Faults of lesser displacement form an indistinct east boundary of the Summer Lake graben.

In the north end of the basin, faulting occurs in two separate sets that combine to break the rocks into a distinct rhombic pattern. These two fault sets were contemporaneous in origin and moved concurrently (Donath, 1962). Seismic-refraction studies conducted at the northern end of the Summer Lake bas in show that faulting continues into the basement rock beneath the al luvium (Donath and Kuo, 1962).

Faulting in the area dates to early Pleistocene times. At that time, the major structural basins and associated highiands were formed (Peterson and McIntyre, 1970). The Winter Ridge fault has had relatively recent movement because landslide debris derived from the ridge has been displaced in places (Peterson and McIntyre, 1970). Evidence exists that the faulting may have succeeded broad regional faulting in the area.

Tertiary rocks consist of basalt, andesite, dacite, and rhyodacite flows, a diorite intrusion, sandstone, siltstone, claystone, tuff, tuff breccias, and welded tuffs. Rocks of late Tertiary-early Quaternay age include basalt and andesite flows, 
basalt ejecta, rhyolitic and dacitic plugs, dikes, domes, and intrusive breccias, clay, sand, silt, gravel and tuff. Deposits of Quaternary age consist of fluvial, al luvial, and lacustrine sediments (Walker, 1963; Walker, Peterson and Greene, 1967; and Peterson and McIntyre, 1970).

The low plateaus and foothills are situated on the horsts (upthrown fault blocks), while the bas in occupies the graben.

The foothills to the south consist primarily of Tertiary tuffaceous sediments intercalated with anedsite and basalt flows, and a Quaternary landslide of basaltic and tuffaceous sedimentary rock. Fir Timber Butte, $3 \mathrm{~km}$ south of Paisley, is a Tertiary-Quaternary rhyolite dome. The Tertiary sediments and flows southeast of Fir Timber Butte are underlain by an early Tertiary dacite flow, which is intruded by a diorite pluton (Walker, 1963; and Peterson and McIntyre, 1970).

The low plateau area is composed primarily of Tertiary basalt and andesite flows interbedded with conglomerate, sandstone, siltstone and tuff. Ten mile Butte is a Tertiary-Quaternary basaltic cinder cone with some basalt flows toward the west and southwest (Walker, 1963, and Walker, Peterson and Greene, 1967).

The basin consists primarily of Quaternary aeolian, alluvial, and terrace deposits of clay, silt, sand, gravel, talus, and evaporite (Walker, 1963) up to 1000 feet thick (Donath, 1962)."

References cited:

Berg, J.W. and Thiruvathuka1, J.V., 1967, Gravity Maps of Oregon, Onshore and Offshore: Oregon Department of Geology and Mineral Industries, GMS-4.

Bowen, R. G. and Peterson, N.V., 1970, Thermal Springs and Wells in Oregon: Oregon Department of Geology and Mineral Industries, Miscellaneous Paper 14.

Donath, F. A., 1962, Analys is of Basin-Range Structure; South-Central Oregon: Geological Society of America Bulletin, V. 73.

Donath, F. A. and Kuo, J. T., 1962, Seismic Refraction Study of Block Faulting, South-Central Oregon: Geological Society of America Bulletin, V. 73.

Peterson, N. V. and McIntyre, J. B., 1970, The Reconnaissance Geology and Mineral Resources of Eastern K Tamath County and Western Lake County, Oregon: Oregon Department of Geology and Mineral Industries Bul let in 66. 
Walker, G. W., 1963, Reconnaissance Geologic Map of the Eastern Half of the Klamath Falls (AMS) Quadrangle, Lake and Klamath Counties, Oregon: U.S. Geological Survey Mineral Investigations Field Studies Map MF-260.

Walker, G. W., Peterson, N. V. and Greene, R. C., 1967, Reconnaissance Geologic Map of the East Half of the Crescent Quadrangle Lake, Deschutes, and Crook Counties, Oregon: U. S. Geologic Survey Miscellaneous Investigation Map I-493.

..Geophysical Summary:

Geophysical data suggest that several faults underlie the alluvium of Summer Lake basin. The location of the hot springs appear to be controlled by the faults.

\section{..Geophysical Studies:}

Berg, J. W. and Thiruvathukal, J. V., 1967, Gravity Maps of Oregon, Onshore and Offshore: Oregon Dept. of Geology and Mineral Industries, GMS-4.

Donath, F.A., and Kuo, J.T., 1962, "Sei smic-Refraction Study of Block Faulting, South-Central Oregon": Geological Society of America Bulletin, Vol. 73, pp. 429-434.

U.S.G.S., 1972, Aeromagnetic Map of the Klamath Falls and Part of the Crescent $1^{\circ}$ by $2^{\circ}$ Quadrangles, Oregon: U.S. Geological Survey Open-File. 


\section{RESERVOIR CHARACTERISTICS}

SITE: SUMMER LAKE HOT SPRING KGRA

. Reservoir Temperature

.Surface: $43^{\circ} \mathrm{C}$

..Subsurface: $140^{\circ} \mathrm{C}$

.. Geochemcial

$$
\begin{aligned}
\mathrm{SiO}_{2}: & 134{ }^{\circ} \mathrm{C} \\
\mathrm{Na}-\mathrm{K}-\mathrm{Ca}: & 112^{\circ} \mathrm{C}
\end{aligned}
$$

..Flow Rates: $75 \mathrm{lpm}$

..pH: 8.43

.. Total Dissolved Solids: 1,120 ppm

..Fluid Chemistry:

Summer Lake Hot Spring
(units $\mathrm{mg} / 1$ )

1790

(microhmos)

Silica

Calcium

Magnesium

Sodium

Potassium

Lithium

Bicarbonate

Carbonate

Sulfate

Chloride

Flouride

Boron

Temperature $\left({ }^{\circ} \mathrm{C}\right)$

Flow

$\mathrm{pH}$
94

2.1

.1

390

4.6

0.15

406

10

120

280

2.2

6.9

43

$75 \mathrm{pm}$

8.43
Ana River Spring

(units ppm) 
.Spring location: Sumer Lake Hot Spring T.33S., R.17E., Sec. 12 NE $1 / 4$

Ana River Spring T.30S., R. 17E., Sec. 6, W.M.

..Est imated Heat Content: $.4 \times 10^{18} \mathrm{Cal}$.

. Subsurface Area of Reservoir: $4 \mathrm{~km}^{2}$

Hot springs occur in two general groups: warm springs at the northern end of Summer Lake, and a southern group consisting of one hot spring (Sumer Lake Hot Spring) and several warm groundwater wellis near Paisley. 
LAND OWNERSHIP AND LEASING

SITE: SUMMER LAKE HOT SPRING KGRA

..Land Ownership: Federal land is administered by the Bureau of land Management - Lakeview District TOTAL AREA FEDERAL

$\frac{\text { (Acres) }}{\text { (Acres) }}$

STATE PRIVATE

$\begin{array}{ll}13,631 \text { (KGRA) } & \text { Approx } \\ 11,460\end{array}$

KGRA

.. Land Leased.

7,521

374

Unknown

..Highest Priced Leases

(Dollars/Acre) $\$ 3.91$

. \$/Acre Lessee

$\$ 3.91$ Supron Energy

$\$ 2.33$ Supron Energy

$\$ 1.77$ Chevron

2,392

Aminoil

2,847

2,282

(Acres) (Acres) 
GEOTHERMAL DEVELOPMENT STATUS

SITE: SUMMER LAKE HOT SPRING KRA

..Present Development Status:

Summer Lake Hot Springs is a privately owned recreation site with several campsites and a pool heated by water from the hot springs. The bath house has been heated geothermally for about 60 years. Two houses at the site are heated with spring water.

..Projected or Planned Development: None known.

89 


\section{INSTITUTIONAL CONSIDERATIONS}

SITE: SUMMER LAKE HOT SPRING KGRA

\section{..Institutional Requirements:}

Geothermal exploration or development activities may require a conditional use permit from the county planning commission.

Two areas south of Summer Lake are being considered for possible inclusion into the National Wilderness Preservation System as part of the U.S. Forest Service RARE II process.

$\begin{array}{lccc}\text { Area } & \text { Area Code } & \text { Administrative District } & \begin{array}{c}\text { Total } \\ \text { Acreage }\end{array} \\ { } } & 6222 & \text { Fremont National Forest } & 8,063 \\ \text { Brattain Butte } & 6223 & \text { Fremont National Forest } & 5,880\end{array}$

..Agency and Pubric Attitudes:

Most of the residents favor the leasing of federal lands.

..Status of Requirements (i.e., EIA/EIS Requirements):

Environmental Analys is Report for geothermal leasing was issued by the Lakeview District BLM in June 1976. 


\section{ENVIRONMENTAL FACTORS}

\section{SITE: SUMMER LAKE HOT SPRING KGRA}

\section{..CLIMATE: Climatic data from Paisley}

..Prevailing Winds: West-spring and summer

$$
\text { South-fall }
$$

..Precipitation (Annual): $28.4 \mathrm{~cm}$

. Average Temperature $9^{\circ} \mathrm{C}\left(48.3^{\circ} \mathrm{F}\right)$

Minimum: $-0.6^{\circ} \mathrm{C}\left(30.8^{\circ} \mathrm{F}\right)$

Maximum: $\quad 20{ }^{\circ} \mathrm{C}\left(68^{\circ} \mathrm{F}\right)$

..Degree Days (Annual): 6,377

..Average frost-free days: 91

..AIR QUALITY:

No measuring stations are maintained in the Summer Lake Basin.

Dust storms are common in the Chewaucan Val ley and around Abert Lake during high winds in the spring and fall. Other particultes include pollen, smoke, wood dust and soil dust. Particulate concentrations vary with the weather. Dry summer winds increase the dust and pollen concentrations, and winter air inversions increase smoke concentrations.

Hydrogen sulfide is dispersed into the air by the hot springs in the area.

Concentrations range from 0.03 to $0.002 \mathrm{ppm}$ in the immediate area of the springs.

\section{..WATER QUALITY:}

Summer Lake drainage basin is a closed down-faulted basin. It drains an area of approximately 87 sq. meters ( $286 \mathrm{sq}$. miles).

The floor of the basin was occupied by pluvial Lake Chewaucan during Pleistocene time. It is currently occupied by Summer Lake which at high levels covers an area $24 \mathrm{~km}$ ( 15 miles) long and $8 \mathrm{~km}$ ( 5 miles) wide with a maximum depth of between $1.5 \mathrm{~m} .(5 \mathrm{ft}$.) and $2 \mathrm{~m}$. $(7 \mathrm{ft}$.$) . Volume at this level is about 300,810$ acre feet. Because of the flat shore and strong winds, the surface area of the lake can increase greatly over short periods of time, with an accompanying increase in rate of evaporation. The lake level flucuates widely from season to season due to diversion for irrigation. The lake is of ten nearly dry in the summer. 
Water in the Summer Lake Basin originates as precipitation. Many springs are scattered throughout the basin. Artesian flows exist where the clay lake deposits have formed a conf ining layer over permeable volcanic rocks.

Ana River Springs has a tremendous flow rate. The springs are the source of the Ana River and the least variable inflow into Summer Lake. Although currently submerged beneath the Ana Reservoir, this is one of the largest springs in the U.S., discharging an average of 90 cfs.

In 1922-23, an earthen dam was constructed below Ana River Springs to divert water into the Summer Lake Canal. The Canal diverts approximately 1106 acre $\mathrm{ft}$. per year, mostly for irrigation. Water has also been diverted at times to maintain suitable waterfowl habitat.

Water loss from the basin is solely from evaporation. Annual evaporative loss from the lake is estimated to be about 39 inches (Phillips and Denburgh 1971). There is no leakage from the basin and the occurrence of springs near the lake indicates that the water table slopes toward the lake. (4)

Water quality data for Summer Lake is presented below.

Water Quality Data for Summer Lake

(Amounts of dissolved solids and of hardness reported in parts per million. Amounts of all other constituents reported as a percentage of total dissolved solids)

Summer Lake

Dissolved solids content

Silica

Calcium 7,200

Magnesium

Sodium

Potassium

Bicarbonate

Carbonate

Sulfate

Chloride

Fluoride

Bromide

Orthophosphate

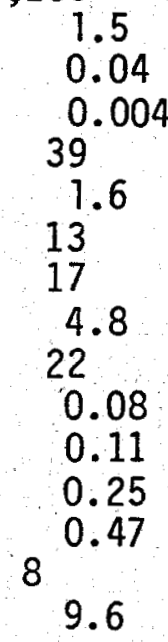

Hardness as $\mathrm{CaCO}_{3}$

$\mathrm{pH}$

9.6

(29) (28)

Source: Phillips and VanDenburgh, 1971 


\section{ENVIRONMENTAL FACTORS}

(continued)

\section{SITE: SUMMER LAKE HOT SPRING KGRA}

\section{. BIOLOGICAL}

. Dominant Flora: Desert Shrub Zone

Vegetation in the Summer Lake bas in varies from very salt

tolerant plants such as the greasewood salt grass (Distichlis

Stricta) association to the non-salt tolerant big sagebrush

(Artemisia tridentata) squirreltail (Sitanion hystrix)

association. Playas and areas of very high salt concentration

are completely devoid of vegetation. Areas below and

surrounding springs and artesian wells support vegetation

typically found in wet meadows such as sedges, carex and others.

Several plant communities exist in the foothills including: low sagebrush (Artemisia arbuscula) and juniper (Juniperus occidentalis). (28)

.. Dominant Fauna:

The greatest abundance and diversity of wildlife is on the Summer Lake Wildlife Management Area on the north end of Summer Lake outside the KGRA. This state managed area is an important breeding and nesting area for migratory waterfow 1 in the Pacif ic flyway. Other animals include: antelope, mule deer, wild horses, pheasant, chukars, coyotes, raptors, reptiles.

Portions of the KGRA are in critical deer wintering range.

... Endangered Species

Flora: No threatened or endangered species are known.

Fauna:

Endangered Species:

American Peregrine Falcon-observations are rare, no known nesting sites.

State of Oregon Threatened List:

Northern Bald Eagle

Kit Fox

Western Spotted Frog

Western Snowy Plover 
..Utility or Energy Transmission Corridors and Facilities

Bonneville Power Administration maintains two transmission lines within the vicinity of Summer Lake. An $800 \mathrm{kv}$ line runs about $35 \mathrm{~km}$ to the east, and a $500 \mathrm{Kv}$ line is approximately $30 \mathrm{~km}$ west of the lake. A private transmission line is situated about $25 \mathrm{~km}$ to the west.

A substation is located about $6.4 \mathrm{~km}$ from Paisley.

. Transportation Cooridors or Facilities

Highway 31

Highway 395

Several unimproved and Forest Service Roads. 
POPULATION

SITE: SUMMER LAKE HOT SPRING KGRA

..General Description of Population:

The Summer Lake area has a very 7 imited population. In addition to the small communities of Paisley (popultion 285) and Summer Lake (population less than 20), there are ranches scattered throughout the basin. The largest community, also the county seat, is Lakeview (population 3,000$) 58 \mathrm{~km}$ south of Paisley.

\section{...Economics}

..Present Land Use:

Major land use is livestock grazing on both public and private land. Privately owned land near the community of Summer Lake produces irrigated native hay and alfalfa.

Agriculture, ranching and wood products are the major economic activities in the Paisley area. Summer Lake has a few retail outlets and a small group of government employees. 

SITE: CRUMP SPRINGS KGRA, OREGON 


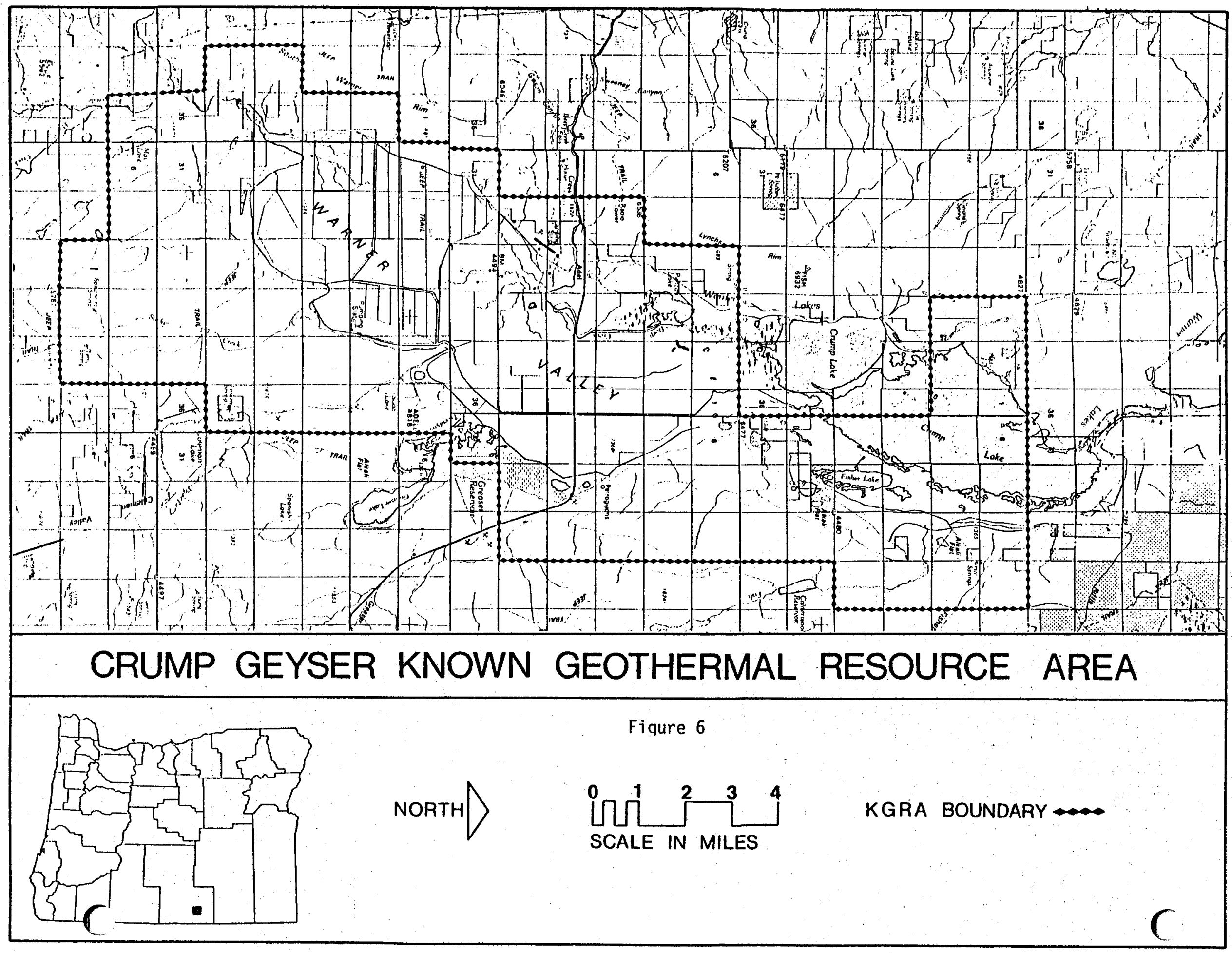




\section{CRUMP SPRINGS KGRA}

The Crump-Warner Valley area is a major structural valley within the Basin and Range province of southern Oregon. The valley is an elongated undrained graben bounded on the east and west by tilted fault block mountains. Several shallow lakes and playas such as Crump, Greaser and Pelican Lakes occupy the basin. The U.S.G.S. has classified 85,663 acres on the valley floor as the Crump Springs KGRA.

The Crump area is relatively isolated in terms of accessibility and low population density. Highway 140, from Lakeview to Denio, Nevada is the primary transportation corridor. Otherwise surface transportation is restricted to secondary roads, most of which are gravel." The few residents in the area live in ranches and rural homesites scattered in the basin. Adel and Plush, the area's only communities, have a combined population of less than 100. Area residents must travel to Lakeview, $37 \mathrm{~km}$ east of Adel, to purchase goods and services not available at the Adel store. Estimated population increases are significantly below projections for most other areas in Oregon.

Both the economy and primary land use are focused almost exclusively on livestock production. Private and public lands are grazed. Agricultural activities are limited to irrigated fields of alfalfa and hay. Most of the cattle are shipped south to California for processing.

In addition to ranching, other land uses include limited timber cutting at higher elevations (Timber is milled outside of the basin.), and recreation, primarily hunting. The Hart Mountain National Antelope Refuge about $12 \mathrm{~km}$ from the KGRA is federally-owned land withdrawn from other uses to provide wildlife habitat.

In association with this limited population and narrow-based economy is a landscape which appears to have significant potential for geothermal resource development. The geologic setting is favorable and thermal activity is evidenced by the presence of hot springs. Geophysical studies lend additional support to the prospect of encountering thermal reservoirs at depth. 
Most of the hot springs are situated in a belt stretching about $10 \mathrm{~km}$ along the west side of Crump Lake. Their location appears to be controlled by the major fault separating the basin from the mountains. A positive magnetic anomaly corresponds to the hot springs zone. Hot springs with the highest surface temperatures are at the southern portion of the zone and are associated with an apparent audio-magnetotelluric resistivity anomaly (Plouff and Conradi, 1975). The highest surface temperature is $99^{\circ} \mathrm{C}$ recorded in 1959 for Crump Well. This reading is above the boiling point for the altitude. More recent field work has recorded the spring temperature at $78^{\circ} \mathrm{C}$ with a measured flow rate of up to 50 liters per minute. Geothermometry indicates an estimated minimum reservoir temperature of $144^{\circ} \mathrm{C}$ based on $\mathrm{Na}-\mathrm{k}-\mathrm{Ca}$ ratios. Several of the springs along the zone are depositing siliceous tuff.

Adjacent to Crump Springs a well was drilled to $513 \mathrm{~m}$. in 1959 . The bottom hole temperature was $77^{\circ} \mathrm{C}$, but temperatures of $121^{\circ} \mathrm{C}$ were encountered at $201 \mathrm{~m}$. The hole was abandoned, but its presence was clearly marked by continuous eruptions of boiling water and steam for about a year. Another shallow well drilled at the same location is currently geysering steam and boiling water at two hour intervals.

Energy companies, recognizing the potential for geothermal development, have acquired leases on federal and private land in the Crump basin. Chevron Oil Company has leased 13,183 acres of public land around the southeastern end of the valley. Gulf Oil Corporation has leased most of the valley floor from Crump Geyser south from private landowners. Various other companies and individuals have amassed geothermal rights on federally-owned land adjacent to the KGRA and private tracts.

Chevron Oil has been conducting the most active exploration program in the valley. A gradient hole drilling program has been on-going since 1976. During 1978, seismic and gravity studies were conducted, presumably to provide information for siting of a deep test hole.

If a deep hole is drilled, it is reasonable to assume that the results of Chevron's exploration have produced encouraging indications of a resource capable of power generation. Otherwise, it seems unlikely that the company would pursue exploration activities.

Unfortunately, the results of their investigations are not publicly available. From published information, estimates of the resource capabilities do not place the Crump area in a range of consideration for electrical power generation. The $144^{\circ} \mathrm{C}$ estimated reservoir temperature is more than adequate for a variety of direct use applications, but the scarcity of population precludes any development along these lines. 
In conclusion, it appears that there are two options for geothermal development in the Crump basin. The first would be to entice industries that can use hot water for processing to locate in the area. This option is limited by the area's remoteness from major transportation networks. The second option is for power production. But confirmation of the reservoir capabilities must be demonstrated before electrical generation can be considered a viable opportunity. 
SITE DATA SUMMARY

SITE: CRUMP SPRINGS KGRA

..Physical Reservoir Date

.. Temperature ${ }^{\circ} \mathrm{C}$

Surface: $78^{\circ} \mathrm{C} \quad$ Subsurface: $180^{\circ} \mathrm{C}$

(1)

..Total Dissolved Solids (PPM) : 668 ppm

..Type of Overlaying Rock: Al luvium and olivine basalt

... Estimated Depth to Top of Reservoir (meters): $1000 \mathrm{~m}$.

.. Site Land Status

Total Acres-85,663 KGRA

$\frac{\text { FED. }}{13,023} \quad \frac{\text { STATE }}{1,280} \quad \frac{\text { PRIVATE }}{\text { Unknown }}$

..Geothermal Development Status:

Utilization of thermal water is limited to stock watering and bathing.

Exploration activities have been carried out at a moderate pace.

.. Local and State Attitude Toward Geothermal Development:

Private land owners have leased their land for geothermal exploration.

There is no known local opposition to the development of geothermal resources.

..Land Use and Population:

The Crump area is sparsely populated. Primary land use activities include livestock grazing, 7 imited agricultural crops and recreation.

Hart Mountain National Antelope Refuge is situated about $12 \mathrm{~km}$ from the KGRA. 


\section{SITE LOCATION AND PHYSICAL DESCRIPTION}

SITE: CRUMP SPRINGS KGRA

..Latitude: $42^{\circ} 15^{\prime} \mathrm{N}$.

..Longitude: $119053^{\prime} \mathrm{W}$.

..Rectilinear:

Secs. 1-4, 9-16, 21-28, 33-36, T.39S, , R.24E., W.M.

Secs. 12, 13, 23-26, 36, 36, T.40S., R.23E.

Sec. 1, T.41S., R.23E.

Secs. $1-3,10-12$, T.38S., R.24E.

Sec. 17, 20, 29, 31, 32, T.39S., R.24E.

Secs. $1-35$, T. $40 S_{\text {. , R. R. }} 4 \mathrm{E}$.

Secs. 2-6, 9-11, T.41S., R.24E.

Secs. $3-10,15-22,28-33$, T.38S., R.25E.

Secs. 4-9, 16-21, 28-31, T.39S., R.25E.

Secs. $13-15,22-28,33-36, T .38 S .$, R.24E.

.. County: Lake

..Adjacent Counties: Klamath, Deschutes, Crook, Harney, Washoe, Nv. Modoc, CA.

..Map Reference: U.S.G.S. - Ade1 1:24,000 Crump Lake 1:24,000

AMS - Adel 1:250,000

.. Topography

Warner Valley is located in the Basin and Range province, an area of major faulting which formed horst and graben

structures. The valley is an elongated undrained graben bounded on both sides by large tilted fault block mountains. Elevations range from $1,363 \mathrm{~m} .(4,473 \mathrm{ft}$. $)$ at Crump Lake to $2,281 \mathrm{~m}$. $(7,483 \mathrm{ft}$.$) on Hart Mountain.$

..Present Land Use:

Livestock grazing is an extensive land use involving most of the area. Agriculture is i imited to feed crops for the livestock industry. Recreational activities include hunting, fishing, and rock hounding. 
..Aesthetics:

Man-made structures are visible for great distances given the nature of the topography.

..Historical/Archaeological Significance:

The EAR states that, "this area may be one of the richest archaeological resources of its kind in the western U.S."

Petroglyph sites, petrified wood, Indian artifacts and occupation sites have been identified.

The historic Central Oregon Military road traverses north of Crump Lake and south of Plush. 


\section{GEOLOGICAL/GEOPHYSICAL DESCR IPTION}

SITE: CRUMP SPRINGS KGRA

.. Geologic Description:

Rocks In the Crump and Warner Valley areas are tuffaceous sediments, tuffs, tuff breccias of andesitic composition with andesite and basalt flows and minor intrusive rhyolites of Miocene to Plio-Pleistocene age. The valleys are filled with lacustrine deposits, Quaternary alluvium and landslide debris. Landsliding is common along the fault scarps on the margins of the graben. North of Crump Lake in the Warner Lakes area, there are large accumulations of complex exogenous domes and related flows and flow breccias of rhyodacitic composition (Walker and Repenning, 1965). Hart Mountain, slightly northeast of Crump Lake, is a large silica volcanic center with steepsides domes and related viscous flows.

Crump and Warner Valleys are within the Basin and Range province which is broken up by two prominent fault sets trending N.200E. and N. $20-35^{\circ} \mathrm{W}$. Vertical displacement along the faults have formed elongated north-trending, undrained grabens such as the Crump and Warner basins. The grabens are bounded on both sides by large tilted falut blocks. The major fault scarp in the Warner Valley is on the east side and the major scarp in the Crump basin is on the west side. According to Donath (1962), the faults of both of the major sets were contemporanceous in origin and movement occurred concurrently along both sets.

Lawrence (1976) suggests that a broad northwest-trending zone of en echelon faults crosses the Crump-Warner graben between Hart and Crump Lakes. As mapped by Lawrence the zone is off set with the eastern portion of the zone ending at Hart Lake on the east side of the graben and crossing about $10 \mathrm{~km}$ to the south and on the western margin of the basin. This part of the graben appears to be structurally anomalous. Many of the hot springs in the Warner area are situated between the two areas of the proposed Eugene-Denio zone. Other hot springs are located in the Crump basin and to the south towards the Surprise Valley. California geothermal area. $(23)(31)(32)(33)(18)$ 


\section{..Geophysical Summary:}

Gravity and aeromagnetic surveys have been completed by Plouff and Conradi.

Gravity readings indicate an asymmetrical basin south of Adel with the deepest margin along the major fault scarp on the west side. Another low north of Hart Lake is separated by a positive gravity ridge from the one south of Adel.

The aeromagnetic survey shows a large negative anomaly centered southeast of Adel extending to the southern end of Greaser Reservoir. Hot springs in the vicinity of Crump Geyser are situated along a narrow belt of a relative magnetic high which appears to extend along the alluvium filled basin floor for about $15 \mathrm{~km}$. (34)

-.Seismic Activity:

Seismic activity was recorded in the Warner Valley in 1968. The epicenters were located south of Crump Lake and averaged 4.9 on the Richter scale. (30)

\section{..Exploration Activities:}

In 1975 the San Juan $0 i 1$ Company drilled a deep test well east of Adel. Total depth was $2,289 \mathrm{~m}$. with a maximum recorded temperature of $86^{\circ} \mathrm{C}$ at $2,288 \mathrm{~m}$. (35)

Nevada Thermal Power Company drilled a $513 \mathrm{~m}$. hole in 1959 in sec. 34, T.38S., R.24E. at Crump Geyser. The we 11 was abandoned due to the low bottom hole temperature of $77^{\circ} \mathrm{C}$. However, temperatures as high as $121^{\circ} \mathrm{C}$ were recorded at a depth of 201 $\mathrm{m}$. The well erupted boiling water and steam continuously for about a year after abandonment. (30) 
Various other exploration activities have been carried out by private companies. Results of these studies have not been made pubicly available. They include:

Hunt 0 il Company -

Chevron 0il Company - drilled between 10-20 $152 \mathrm{~m}$. gradient holes

completed an electrical resistivity survey and a drilling program consisting of $15152 \mathrm{~m}$. gradient holes in 1976 and 1977. Another gradient hole was drilled in late 1977 to a total depth of $439 \mathrm{~m}$. During the fall of 1978 Chevron was conducting seismic and gravity studies in the south Crump Area. If the results of these studies are encouraging, it seems likely that the company will drill a deep test hole before 1980 . 


\section{RESERVOIR CHARACTERISTICS}

\section{SITE: CRUMP SPRINGS KGRA}

. Reservoir Temperature

. Surface: $78^{\circ} \mathrm{C}$

..Subsurface: ${ }^{180^{\circ} \mathrm{C}}$

..Geochemical

$$
\begin{array}{r}
\mathrm{SiO}_{2}: 173^{\circ} \mathrm{C} \\
\text { Na-K-Ca: } 144{ }^{\circ} \mathrm{C}
\end{array}
$$

Crump Hot Springs

...Flow Rates: $0-50 \mathrm{lpm}$

..pH: 7.26

..Total Dissolved Solids: 668 ppm

..Fluid Chemistry:

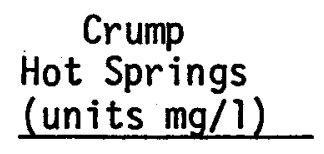

Silica

Calcium

Magnes ium

Sodium

Potassium

Lithium

Bicarbonate

Carbonate

Sulfate

Chloride

Flouride

Boron

Temperature $\left({ }^{\circ} \mathrm{C}\right)$

$\mathrm{pH}$

flow
180

16

$280^{.2}$

11

153

1

200

240

4.9

13.6

78

7.26

$0.50 \mathrm{lpm}$
Fisher Hot Springs

(units mg/l)

77

8.4

1

92

7.9

.04

1

59

56

3.5

2.2

68

7.93

$707 \mathrm{pm}$
Antelope Hot Springs

(units ppm)

168

10

2.5

191

13

57

64

3.6

0.2
1.5

40

8.3

Location: Crump Hot Spring - Sec. 27, T.38S., R.24E. W.M. Fisher Hot Spring - Sec. 10, T.38S., R.25E Antelope Hot Spring - Sec. 32, T.35S., R.26E 
A shallow well drilled at Crump Hot Springs, known as Crump Geyser, erupts boiling water and steam at approximately two hour intervals. At the same location, another well drilled in 1959 to $488 \mathrm{~m}$. geysered continuously for about one year.

.. Est imated Reservoir Heat Content: $\quad .8 \times 10^{18} \mathrm{cal}$

..Subsurface Area of Reservoir: $4 \mathrm{~km}^{2}$ estimted 
LAND OWNERSHIP AND LEASING

SITE: CRUMP SPRINGS, KGRA

..Land Ownership - TOTAL AREA (KGRA) - 85,663 acres

..Land Leased - FEDERAL (Acres) - 13,023

PRIVATE (Acres) - Unknown

STATE (Acres) - 1,280

..Highest Priced Leases (Dollars/Acre) - \$8.18/acre

. \$/Acre

Lessee

FEDERAL (Acres)

4.13

5.12

3.17

Chevron $0 i 1$

2,520

1,120

3.11

2,560

3.14

8.18

1,942

1,920

5.16

1,600

1,360

. Tentative Lease Sale Dates: None Known

.. Number of Sales Offered But No Bids:

Various tracts have been offered during three lease sales which received no bids.

. Leased Land:

Chevron 0 il Company holds leases on 13,023 acres within the KGRA. State land totalling 1,280 acres have been leased to Intercontinental Energy. Non-competitive and leases on private land are held by Gulf 0i1, Union 0il, Magma Power, Standard 0i1, the Hunt family and various individuals.

.. Summary of Leasing Status and Needs:

Lease sales were held on $7 / 31 / 75,12 / 9 / 76$ and $7 / 27 / 78$.

In 1975 units $1-18$ were offered, but only tract $8,9,11$ and 14 were leased. Units 4-17 were reoffered in 1976 with 11, 13, and 14 being leased to Chevron 0il Company. Again in 1978 units 1-13 were reoffered, but no bids were received.

(6) 


\section{GEOTHERMAL DEVELOPMENT STATUS}

\section{SITE: CRUMP SPRINGS KGRA}

..Present Development Status:

Warm water wells are used for stock watering.

Undeveloped hot springs on Hart Mountain are used for bathing.

Exploration activities have been taking place at a moderate pace. 
INSTITUTIONAL CONSIDERATIONS

SITE: CRUMP SPRINGS KGRA

..Institutional Requirements:

Exploration and development activities may require a conditional use permit from Lake county.

...Agency and Public Attitudes:

There is no known local opposition to geothermal exploration.

..Status of Requirements (i.e., EIA/EIS Requirements)

Bureau of Land Management completed an Environmental Analys is

Record covering geothermal leasing in the Warner Valley in 1975. 


\section{ENVIRONMENTAL FACTORS}

\section{SITE: CRUMP SPRINGS KGRA}

. CL IMATE

..Prevailing Winds: West to southwest

. Precipitation (Annual): $27 \mathrm{~cm}$ (Hart Mountain Refuge)

. Average Temperature $9^{\circ} \mathrm{C}\left(48^{\circ} \mathrm{F}\right)$

Minimum: $-2{ }^{\circ} \mathrm{C}\left(29^{\circ} \mathrm{F}\right)$

Maximum: $20^{\circ} \mathrm{C}\left(69^{\circ} \mathrm{F}\right)$

Temperature extremes range from $37.7^{\circ} \mathrm{C}$ in the summer to $-26^{\circ} \mathrm{C}$ in the winter.

.. Degree Days (Annual): 7,069 (Lakeview)

. Relative Humidity: low

-.AIR QUALITY:

Although there are no monitoring stations in the area, the air appears to be of high quality. Wind blown dust from the dry basin contributes particulate matter. The hot springs disperse hydrogen sulfide gas. Concentrations are approximately $0.03 \mathrm{ppm}$ in the immediate vicinity of the springs. (30)

-.WATER QUALITY:

Most of the groundwater in the basin occurs in alluvial deposits. Well depths range from $41 \mathrm{~m}$. to $183 \mathrm{~m}$., with water depths varying from $3 \mathrm{~m}$. to $123 \mathrm{~m}$. Coarse gravel deposits yield a range from a few hundred to more than $1,000 \mathrm{gpm}$. The finer-grained sediments give smaller yields. Groundwater is used primarily for stock watering and domestic purposes.

Groundwater is variable in quality, but is generally less than $500 \mathrm{mg} / \mathrm{l}$ of dissolved solids. High concentrations of sodium, boron and flouride have been measured in some places.

At higher elevations groundwater occurs in volcanic rocks. Yields vary from small to moderate with an occassional large yield. Water quality shows a wide range with excessive concentrations of sodium and boron in some places, but generally dissolved solids are below $100 \mathrm{mg} / 1$. 
Monitoring information is available for two tributaries to Crump Lake, Twentymile and Deep Creeks. South of Adel, Twentymile Creek has an average discharge of $1.5 \mathrm{~m}^{3} / \mathrm{s}(38,500$ acre-feet/year) with no flow recorded at times. Deep Creek which flows into. Crump Lake at Adel has an average flow of $3.7 \mathrm{~m}^{3} / \mathrm{s}(94,900$ acre-feet/year). Periods of no flow have also been recorded for Deep Creek. During low flow, the creek has approximately $90 \mathrm{ppm}$ total dissolved solids.

Surface water in the streams is generally a calcium-magnesium bicarbonate type with low amounts of dissolved solids and hardness. Most of the surface water rights have been appropriated for irrigation purposes.

Water from Crump Lake is also important for irrigation purposes. Dissolved solids vary between $100-500 \mathrm{ppm}$ with fluctuations in the lake level. Any overflow from Crump Lake goes into Hart Lake which occassionally is dry due to pumping for irrigation. Any overflow of Hart Lake goes into the series of Warner Lakes which increase in salinity northwards until all of the water is lost to evaporation. (30)(29)

. BIOLOGICAL

..Dominant Flora:

Perennial grasses, big sagebrush, greasewood, low sagebrush, and various forbs. Western juniper associations on the plateaus and lower mountain slopes.

..Dominant Fauna:

Mule deer, antelope, sagegrouse, coyotes, bobcats, jackrabbits, raptors, rodents, wild horses, and others. Much of the area has been designated as critical deer winter range. Antelope kidding grounds at Hart Mountain National Antelope Refuge are situated nor thwest of Crump Lake.

The Warner lakes area is particularly valuable for waterfowl habitat.

Pelican Lake contains a small island which serves as a rookery for white pelican, egret, heron and cormorant. Ducks, geese, swans, and grebes are common aquatic species.

..Endangered Species

Flora: None known.

Fauna: Peregrine Falcon Southern Bald Eagle 


\section{TRANSPORTATION AND UTILITIES}

\section{SITE: CRUMP SPRINGS KGRA}

.Utility or Energy Transmission Corridors and Facilities

A major $800 \mathrm{kv}$ Bonneville Power Administration transmission line running from the Columbia River to California crosses the plateau west of the Warner Valley.

A $69 \mathrm{kv}$ line runs from Lakeview to Adel.

One of the proposed routes of Pacific Power and Light Company's $500 \mathrm{kv}$ line from Idaho to Malin, Oregon may run close to the KGRA.

..Transportation Corridors or Facilities

Higiway 140

Secondary and gravel roads 


\section{POPULATION}

SITE: CRUMP SPRINGS KGRA

..General Description of Population

Population in the Crump-Warner area is extremely limited. Rural homesites and ranches are scattered in the valley with Adel and Plush being the only communities in the area. Lakeview is the closest town of sufficient size to provide goods and services. Adel, with an estimated population of 43 , is $37 \mathrm{~km}$ east of Lakeview. Plush is a community of about 54 situated $54 \mathrm{~km}$ northeast of Lakeview.

Population for the area is expected to grow only slightly by 1980 , at about $1 / 3$ the rate for other areas in Oregon. (30)

\section{...Economics}

..Present Land Use:

The economy of the area is narrowly based and depends almost entirely on livestock production, limited agriculture and lumber mills. 


\section{SITE: ALVORD KGRA, OREGON}




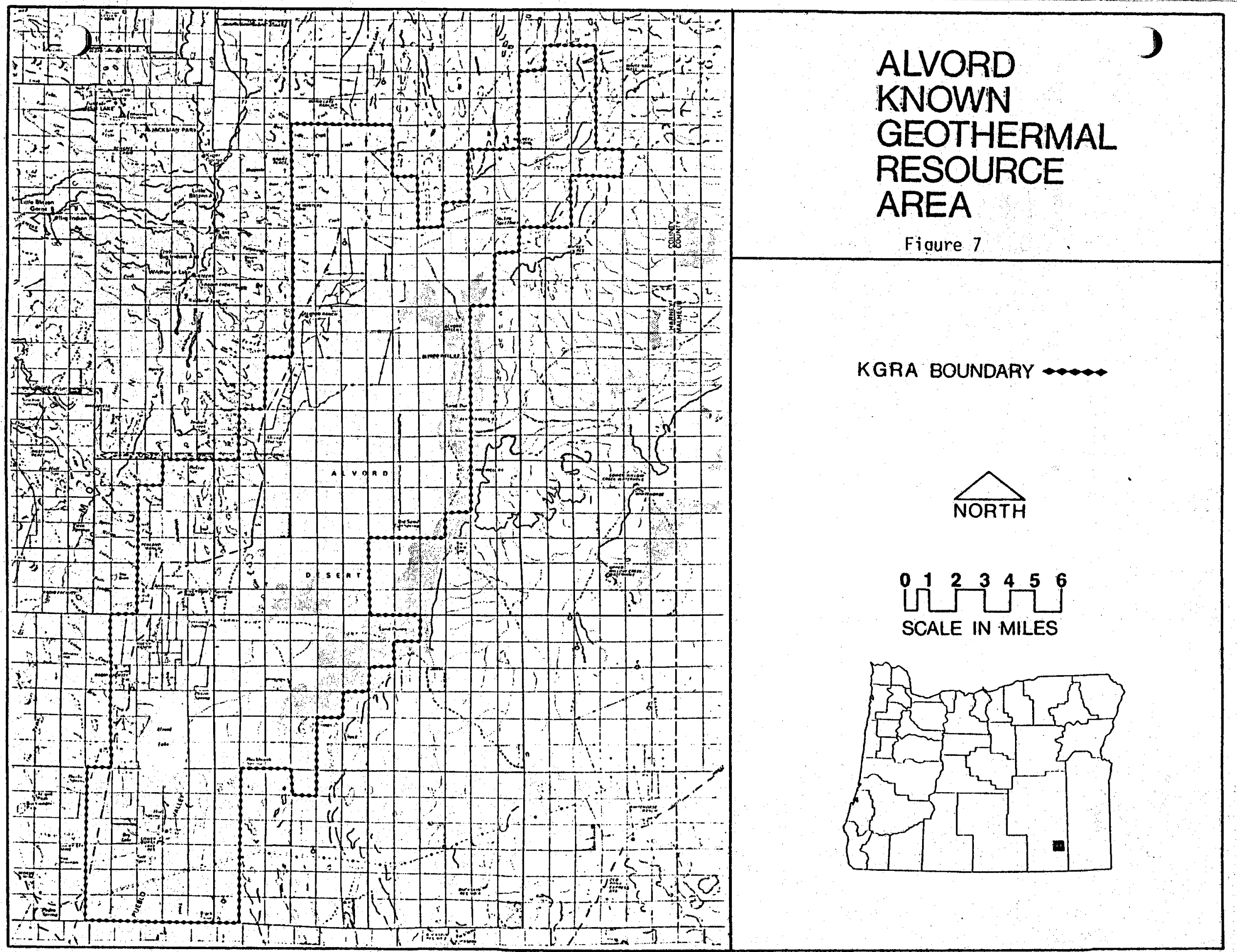




\section{ALVORD KGRA}

The Alvord Valley is a highly scenic and remote area in the northern part of the Basin and Range province of southeastern Oregon. The valley is a major structural graben bounded on the west by the Pueblo and Steens. Mountain and by Trout Creek Mountains on the east. This horst and graben type topography is the result of large predominately vertical displacements along major faults. Shallow saline lakes and playas occupy the central portions of the Valley.

Within the basin, 176,835 acres have been designated as a KGRA, making Alvord the largest area in Oregon of known resources according to the U.S.G.S. classification. The KGRA covers most of the valley floor from Fields to northeast of Mickey Hot Springs. The majority of the land is owned by the federal government and managed by the Burns District Office of the BLM. A considerable portion is held in private ownership.

Both public and private lands are used almost exclusively for livestock grazing. Livestock production virtually is the sole base of the area's economy. To supply winter feed, alfalfa and hay are grown on small irrigated tracts of land.

The harsh environment and remoteness of the Alvord Valley restricts land use and population. Besides ranching, the principal land use is for recreation and hunting. The greatest influx of people occurs during hunting season.

The area is so remote that it is likely that feral horses outnumber people. Fields with a year round population of 11 is the largest community in the immediate vicinity. There are no paved roads and the closest incorporated town is more than $160 \mathrm{~km}$ distance from the Valley. Mail service has recently been expanded to three deliveries a week. Children of high school age attend a boarding school about $180 \mathrm{~km}$ from home. The closest service center for residents of the area is Burns which is about $200 \mathrm{~km}$ northwest of Fields. The majority of the population comprises owners and employes of ranches headquartered in the Valley. Total population of the KGRA and closely adjacent areas is less than 50.

Considering these population characteristics and the area's remoteness a discussion of direct use applications of geothermal energy is not warranted. If geothermal development occurs in the Alvord Valley, it will be for isolated applications to provide space heating of residences or for electrical power generation. 
The geologic setfing and geophysical studies indicate that the area may have potential for geothermal power generation. A summary of the physical characteristics relevant to geothermal development is presented in the data sheet following this section.

The presence of thermal activity in the Alvord Valley is clearly indicated by three major hot spring areas. According to the U.S.G.S. Circular 726, Mickey, Alvord and Borax Lake Hot Springs have the highest estimated subsurface temperatures in Oregon. The subsurface temperatures are an assumed average reservoir temperature and are calculated as $210^{\circ} \mathrm{C}$ for Mickey Hot Springs, $200^{\circ} \mathrm{C}$ for Alvord Hot Springs and $180^{\circ} \mathrm{C}$ at Borax Lake. The thermal springs and pool at Borax Lake is also known as Hot Lake.

Temperature gradient drilling, heat-flow measurements and geophysical investigations have further supported the possibility of commercial development of geothermal resources in the Alvord Valley. Audio-magnetotelluric apparent resistivity studies have indicated three large anomalies each associated with the major hot spring areas (Long and Gregory, 1975). The highest heat-flow was measured at Mickey Hot Springs with a value of $6.4 \mathrm{HFU}$ considerably above the regional average of $1.5 \mathrm{HFU}$ (Sass, 1976). The preferred reservoir model is three separate systems rather than one large hydrothermal convection system (U.S.G.S. Circular 726).

Environmental concerns of geothermal leasing in the Alvord basin were addressed in an environmental analysis report issued by the BLM in January 1975. Since that time, leasing has been active. Three lease sales were held by June of 1975 where a total of 23,661 federal acres were leased. In addition, 2,800 state-owned acres and approximately 41,500 acres of private land have been leased.

Several major energy companies hold leases and have been conducting fairly active exploration programs since 1976. To date these investigations have been geophysical studies and shallow gradient drilling. Deep temperature gradient drilling was scheduled to begin in late 1978.

Although this activity is encouraging, the area is not without its problems. The BLM rejected six competitive bids from Union and Getty Oil Companies for being too low. The cases were appealed to the U.S. Department of Interior's -Board of Land Appeals in 1975. Getty's appeal was denied but the Union Oil case is still pending.

In addition, the Sierra Club and High Desert Study Group filed suit against the BLM alleging an insufficient environmental analysls. The case was heard in U.S. Circuit Court in January 1978 and a preliminary injunction barring leasing was denied. The court's final decision had not been released as of late 1978. 
Reoffering and leasing of additional units within the KGRA is not likely until litigation is complete. A BLM roadless and wilderness study is also hindering additional leasing. Two competitive lease sales were postponed in 1978 because the study was not complete.

There are physically limiting factors in the KGRA as well. One consideration is the limitation of surface water availability. The lakes in the basin are strongly alkali and have depths generally less than one foot. The availability and quality of subsurface waters is not well known. In addition, waters of the major thermal springs have unusually high concentrations of boron and lithium.

Taking all these factors into consideration, the development of geothermal resources for electrical power generation in the Alvord Valley must be viewed as highly speculative. Foremost is the unproven existence of a viable reservoir.

If exploration activities discover a capable reservoir and environmental concerns can be mitigated, there should be no severe technological problems at the site. A binary power-plant system seems most likely for the Alvord, and by the time development begins, experience from binary plants under construction at Heber and Raft River should be available to influence development in the Alvord Valley. An existing transmission line further enchances the outlook for geothermal electrical production, but the resource must first be proven. 
SITE DATA SUMMARY

SITE: ALVORD KGRA

..Physical Reservoir Date

..Temperature ${ }^{\circ} \mathrm{C}$ Surface: $76^{\circ} \mathrm{C}$

Subsurface: $200^{\circ} \mathrm{C}$

.. Total Dissolved Solids (PPM) : 1440 ppm Alvord Hot Spring

..Type of Overlaying Rock: Alluvium, andesite and basalt

..Estimated Depth to Top of Reservoir (meters): 1000-1500

..Site Land Status

Tota1 Acres - 176,835 KGRA

Total Acres Leased - FEDERAL - 23,661

STATE - 2,800

PRIVATE - 41,500

..Geothermal Development Status:

Alvord Hot Springs is used for bathing. Warm wells are used for stock watering.

Exploration for geothermal resources has been fairly active.

..Local and State Attitude Toward Geothermal Development:

Local attitudes are supportive of geothermal development as long as existing land uses and aesthetic values of the area are maintained.

..Land Use and Population:

The area is extremely remote with a population density of less than one person per square kilometer. Primary land use is livestock grazing.

Secondary uses include: recreational activities, wildlife habitat, ranch headquarters, irrigated cropland and watershed.

... Comments and Critical Issues:

The area is remote with rugged terrain.

Most of the ranches in the area depend upon grazing livestock on public land for their economic survival. There is limited to no opportunity for alternate forage supplies should public lands become unavailable or unsuitable for grazing. 


\section{SITE LOCATION AND PHYSICAL DESCR IPTION}

SITE: ALVORD KGRA

..Latitude: $420321 \mathrm{~N}$

..Longitude: $118^{\circ} 31^{\prime} \mathrm{W}$

..Rectilinear:

Secs. 1, 2, 10-15, 22-27, 34-36, T.35S., R.33E. W.M.

Secs. $1-4,9-16,21-28,33-36$, T.36S., R. 33E.

Secs. $1-5,8-17,20-29,32-36$, T.37S., R.33E.

Secs. $34-36, T$. $325 .$, R. 34E.

Secs. $1-3,10-15,22-27,34-36$, T. 33S., R.34E.

Secs. $1-3,10-16,21-29,32-36$, T.34S., R.34E.

Secs. $1-36, T .35 S$., R.34E.

Secs. $1-23,27-34$, T.36S., R.34E.

Secs. $3,6,7,18,19,30,31$, T.37S., R. 34E.

Sec 31, T.32S., R. 35E.

Secs. 1, 2, 6-8, 11-15, 17-24, 26-35, T.33S., R.35E.

Secs. $3-10,15-22,27-34$, T. 34 S., R. 35E.

Secs. 3-10, 16-21, 28-32, T.35S., R.35E.

Secs. $5-7$, T.36S., R.35E.

Secs. $16,17,19-21,28-33$, T. 32S., R. 36E.

Secs. 5-8, 17, 18, T.33S., R.36E.

..County: Harney

..Adjacent Counties: Malheur, Grant, Crook, Lake and Humboldt, Nv.

..Map References: U.S.G.S. - 1:24,000 - Andrews, Borax Lake, Alvord AMS - 1:250,000 - Adel

. Topography:

The Alvord Val ley lying within the Basin and Range province is a north-to-northeast trending graben approximately $112 \mathrm{~km}$. long and 3-16 km wide bounded on both sides by high angle normal faults. The Steens and Pueblo Mountains border the valley on the west and it is fringed on the southeast by the Trout Creek Mountains. Elevations range from $1,219 \mathrm{~m}$. on the bas in floor to $2947 \mathrm{~m}$. at the highest point in the Steens. The central portion of the valley contains playas, sand dunes and shallow sal ine lakes. The arid to semi-arid climate restricts natural vegetation to sagebrush associations. 
..Present Land Use:

Land use is almost exclusively used for livestock grazing.

Some private land is irrigated for growing hay and alfalfa.

Other uses include: big game hunting, wildlife habitat, off-road vehicles, sightseeing, rock climbing and other recreational activities.

..Future Land Use Plans:

No significant changes in land use are anticipated.

..Aesthetics:

The Steens Mountain and Alvord Desert together form a unique landscape with high aesthetic value. The valley is nearly flat which makes man-made structures visible for great distances.

\section{..Historical/Archaeological Significance:}

A preliminary reconnaissance archaeological survey was made in Dec. 1974. Some 17 cultural sites were identified. The sites are of two basic types, rockshelters and open sites. The shelters are apparently wave cut, with basal layers of water rolled gravel. Open sites appear to have been composites near streams, springs and dunes. The artifacts collected were all 1ithic materials. Both chipped stone and ground stone industries are represented. The objects collected suggest occupancy by aboriginal people over the period from very recently (150 years ago) to as ancient a time as 7,000 to 11,000 years ago. One site, identified as Broken Bones Site (ADP-7) was suggested as suitable for nomination to the National Register of Historic Places. This may be an extremely early site, possibly related to the so-called Plano division of the early hunters or Paleo Indian stage of the New World. This site is located about 4 miles northwesterly of Fields, two miles southwesterly of Hot Lake, and lies in and south of a set of sand dunes.

The area is known for its history of settlement by livestock ranchers. (36) 
GEOLOGICAL/GEOPHYSICAL DESCRIPTION

SITE: ALVORD KGRA

..Geologic Description:

The geology of the Alvord Valley has been summarized in the environmental analysis as follows:

"The Alvord Valley has been described as a graben structure by various authors (Russe11, 1884; Fuller, 1931; Libbey, 1960; Groh, 1966; and others). The valley is bounded on the west by the Steens-Pueblo Mountains and the Steens Mountain fault, a large basin-and-range type fault with a minimum vertical displacement of 5,500 feet and a suggested maximum vertical displacement of 10,000 feet (Libbey, 1960). On the east, the valley is bounded by lesser faults associated with basin-and-range structures. The age of faulting is Pliocene to very recent Holocene. Russell (1884) reported very recent movement along the old fault scarp. He reported finding a fresh recent displacement, "unclothed with vegetation", with a vertical displacement of 20 to 50 feet with hot springs seen issuing forth along the base of the fault. Russell (1884) al so reports fresh movements of faults along the eastern front of the Pueblo Mountains for a distance of 40 to 50 miles. The occurrence of volcanic rocks close to the base of the fault scarp forming the high Steens and the concentration of basaltic mafic dikes near the mountain base imply that the boundary faults coincide with an old belt of tensional release (Williams and Compton, 1953).

The Steens Mountain Range marks the western boundary of the Alvord Desert. In general, the range consists of a great structurai mass dipping gently westward from a high eastern fault scarp. The mountains can be divided roughly into three parts, of which the most prominent feature is a very simple high central block. On both the north and south this is bounded by lower, more complex units referred to as the Northern and Southern Steens, respectively. 
Tertiary volcanics and volcanic sediments comprise most of the Steens Mountain Range. The volcanic sequerice totals about 10,000 feet in thickness and includes the Alvord Creek formation, Pike Creek volcanic series, Steens-Pueblo volcanic series and the Steens Basalt. These units contain basalt, andesite, dacite and rhyolite lava flows, tuffs and tuffaceous sediments, and volcanic agglomerates with some minor opaline chert and conglomerate.

Pre-Tertiary rocks are exposed in the Pueblo Mountains south of Fields. These exposures consist of metamorphosed sedimentary and volcanic rocks (greenstones, argillites, quartzites, phyllites, and schists) of Permian or Triassic age intruded by Jurassic monzonitic and dioritic plutons.

The Alvord Valley has been filled with lacustrine fluvial and aeolian sediments to an unknown depth. Playas and shallow lakes within the basin and elevated relic shorelines indicate that a large lake of about 400 feet deep existed at one time and is now represented by ephemeral Alvord, Mann and Jun iper Lakes.

Walker and Repenning (1965) report the presence of many vents of smali lava cones, cinder cones, plugs, or necks adjacent to the Alvord graben on the west and east sides. Also present are mafic dikes and dike swarms. Williams and Compton (1953) mention that "about 25 years ago" (1928), a few earthquakes occurred in the Alvord area. The hot spring at Borax Lake (Hot Lake) in section 11, T.37S., R.33E., in the floor of the graben, showed exceptional activity during the period of earthquakes. The cause of the earthquakes was postulated to be movements along the transverse fault on the south side of the horst opposite Alvord Lake. Also, Williams and Compton (1953) report that 12 shocks were felt on August 9 and 10, 1943. The shocks were attributed to movement along one of the transverse faults in the area." 
References cited:

Fuller, R. E., 1931, The Geomorphology and Volcanic Sequence of Steens Mountains in Southeastern Oregon: Washington Univ. Geology Pub., Vol. 3, No. 1, p. 1-130.

Groh, E. A., 1966, Geothermal Energy Potential in Oregon: Ore Bin, Vol. 28, No. 7, p. 125-135.

Libbey, F. W., 1960. Boron in Alvord Valley, Harney County, Oregon: Ore Bin, Vol. 22, No. 10, p. 97-105.

Russe11, I. C., 1884. A Geological Reconnaissance in Southern Oregon: U.S. Geological Survey 4th Annual Report, p. 431-464.

Walker, G. W., and Repenning, C. A., 1965. Reconnaissance Geologic Map of the Adel Quadrangle, Lake, Harney, and Malheur Counties, Oregon: U.S. Geological Survey Misc. Geologic Investigation Map I-446.

Williams, H., and Compton, R. R., 1953. Quicksilver Deposits of Steens Mountain and Pueblo Mountains Southeast Oregon: U.S. Geological Survey Bullet in 995-B.

..Minerals:

U.S. Geological Survey has identified most of the Alvord as prospectively valuable for $0 i 1$ and gas, sodium and potassium.

The only commerical development for mining sodium was a borax works around the turn of the century at Borax Lake (also known as Hot Lake). At its peak, the mine had an output of 400 short tons of refined borax per year. The mine closed in the early 1900's. (36)

Mercury has been mined in the area producing a total of 66 flasks. (36)

Other identified minerals: copper, gold, uranium, zeolite, clinoptilolite, diatomite and gravel. (36) 


\section{...Geophysical Summary:}

Gravity studies have been conducted in the hot springs areas by Griscom and Conradi (1975). Several small inf lections were ident ified which correspond to magnetic anomal ies. They have been interpreted as small faults projecting through known hot springs. Three other anomalies, due to smal1, shallow density differences were located. Two of these were positive anomalies south of Borax Lake, and the third was a $1.4 \mathrm{mgal}$ low at Mickey Hot Springs.

Griscom and Conradi (1975) have also conducted detailed magnetic profiles in the basin. An area of magnetic noise associated with the shallow positive gravity anomalies was identified near the faults at Borax Lake hot springs. Depth to the magnetic body is reportedly less than 200 feet. Griscom and Conradi suggest that the gravity and magnetic anomalies may indicate chemical reactions of hot saline waters that have generated a small amount of magentic minerals near faults in the otherwise nonmagnetic alluvium. (38)

Long and Gregory (1975) have completed an audio-magnetotel luric apparent resistivity survey in the basin floor. Anomalies were shown in association with Mickey, Alvord and Borax Lake Hot Springs. The largest anomaly and the lowest apparent resistivities was several miles east of Alvord Hot Springs in the center of the Alvord Desert. 'This suggests that Alvord Hot Springs is supplied by a reservoir in the center of the basin. Overail results of the survey how that the hot springs are supplied by different sources and not by one large reservoir. (39)

Heat-flow studies in the Alvord Valley have been conducted by Sass, Galan is, Munroe and Urban (1976) and Bowen, Blackwell and Hul1 (1975). The regional values have a range of $1.1-2.3$ HFU with $1.5 \mathrm{HFU}$ as an average.

Sass and others (1976) measured high heat flow $(6.4 \mathrm{HFU})$ in close proximity to Mickey Hot Springs. Heat flow values decrease to $3.2 \mathrm{HFU}$ two kilometers away from Mickey Hot Springs. This drop in heat flow is similiar to observations at other hot springs. (40) 
Temperature gradient and heat-flow studies by Bowen, Blackwell and Hull (1975) identified an anomaly in the Trout Creek area of the Alvord Valley. Gradients were logged in preexisting mineral exploration holes varying from 50 to $150 \mathrm{~m}$. depth. The gradients range from 68 to $139.40 \mathrm{c} / \mathrm{km}$. The highest gradient was measured near Trout Creek and is twice the regional average. Heat-flow values range from 1.6 , to $3.2 \mathrm{HFU}$.

Heat-flow measurements were also obtained in an existing mineral exploration hole at Steens Mountain southwest of Fields. The average gradient to $370 \mathrm{~m}$. is about $600 \mathrm{c} / \mathrm{km}$. The heat-flow value is $2.26 \mathrm{HFU}$, considerably above the regional average. (41)(42)

-. Exploration Activities:

The following is a partial list of exploratory work that has been or is being conducted in the Alvord Valley. For the most part these activities are being carried out by private companies, therefore the data is not publicly available.

U.S.G.S. Phillips Petroleum Union 0 il Al-Aquitaine

1976

1977

1978
Chevron 0 il Geonomics Anadarko Supron Energy Aminoil

Union $0 i 1$

Phillips Petroleum Anadarko
Drilled 4 shallow gradient holes.

Drilled 28 gradient holes to $91 \mathrm{~m}$.

Drilled 13 gradient holes to $61 \mathrm{~m}$.

Drilled 11 gradient holes to between 61-152 m.

Drilled 13 gradient holes to $152 \mathrm{~m}$. Dipole and magnetotelluric Electrical resistivity

Planned geophysical surveys

Began a drilling program of $6152 \mathrm{~m}$. gradient holes in $9 / 78$

Drilled $6152 \mathrm{~m}$. gradient holes near Mickey Hot Springs.

Drilled a $555 \mathrm{mo}$ gradient hole Magnetotelluric and electrical resistivity surveys. Drilled a $522 \mathrm{~m}$. gradient hole. Permited for $9610 \mathrm{~m}$. gradient holes. Began a planned drilling program of $75152 \mathrm{~m}$. in $9 / 78$. 
..Hydrology:

The climate of the Alvord Valley is arid to semi-arid. The area lies in the rainshadow of the Steens-Pueblo Mountains which

limits the annual average precipitation in the basin to 8 inches.

The basin contains several shallow lakes and playas, a few perennial streams which drain the surrounding mountains, and some flowing springs, several of which are thermal. All drainage is into the basin. Water collects on the numerous smalf playas in the area and on Alvord Desert and Alvord Lake where it evaporates.

The largest lake in the basin is Alvord Lake. Maximum water depth does not exceed a foot and its surface area varies with the season and precipitation. It is usually dry by mid-summer and has an alkali crust on the surface. During periods of heavy precipitation the lake may overflow into the Alvord Desert which is a large playa.

Trout Creek is the largest perennial stream and flows toward Alvord Lake from the southeast. The average volume is 11,200 acre-feet/year with a flow rate of $0.4 \mathrm{~m}^{3} / \mathrm{sec}$. (U.S.G.S. Water Data Report, 1975). Much of the flow from Trout Creek is diverted for irrigation purposes or sinks into the alluvial basin floor so that little, if any, water reaches Alvord Lake.

There are three main areas of thermal springs in the Alvord Valley. The northernmost is Mickey Hot Springs which includes flowing springs, fumaroles, several vents, small pools, sinter cones and boiling mud pots. Several springs discharge $100 \mathrm{lpm}$ of $73^{\circ} \mathrm{C}$ water and are depositing sinter. It is reported that the area surrounding the springs has a hollow sound when walked over and that water can be heard underground.

Alvord Hot Springs is situated about $24 \mathrm{~km}$ southwest of Mickey Hot Springs along the western boundary of the graben. The series of 6 to 8 springs are aligned in a north-south direction which indicates fault control. Surface temperature of Alvord Springs is $76^{\circ} \mathrm{C}$ with an estimated flow rate of $5001 \mathrm{pm}$. Two pools and a sheet metal structure have been constructed at the site for public bathing. 
Borax Lake Hot Springs, al so known as Hot Lake, is the southernmost group. They are located around the old borax works. Several springs follow a northwest-trending fault mapped by Waiker and Repenning (1965). A large pool, Borax Lake, approximately 275 yards in diameter has been formed at the southern end of the line of springs. Surface temperatures have been measured as $36^{\circ} \mathrm{C}$ and $98^{\circ} \mathrm{C}$ with a flow rate of $200 \mathrm{lpm}$. The springs are also depositing siliceous sinter.

These springs are the water source for Borax Lake. Water flows out of the lake through two channels, one on the west side and one on the south side. The flow generally goes into Lower Borax Lake Reservoir or into ponds northeast of the reservoir.

The three main groups of thermal springs in the Alvord Valley. have unusually high concentrations of boron and lithium. This seems to indicate that the waters may be migrating through the val ley al luvium where evaporites occur in small playas rather than from the surrounding mountains. (36)(37) 


\section{RESERVOIR CHARACTERISTICS}

SITE: ALVORD KGRA

..Reservoir Temperature

Alvord Mickey
Hot Springs Hot Springs Lake Spring

.. Surface:

$$
{ }^{76}{ }^{\circ} \mathrm{C}
$$$$
73^{\circ} \mathrm{C}
$$

$96^{\circ} \mathrm{C}$

.. Subsurface:

$200^{\circ} \mathrm{C}$

$210^{\circ} \mathrm{C}$

$180^{\circ} \mathrm{C}$

..Geochemical

$\mathrm{SiO}_{2}$ :

$148^{\circ} \mathrm{C}$

$180^{\circ} \mathrm{C}$

$165^{\circ} \mathrm{C}$

Na-K-Ca:

${ }^{199{ }^{\circ} \mathrm{C}}$

$207^{\circ} \mathrm{C}$

$176^{\circ} \mathrm{C}$

..Total Dissolved Solids: Alvord Hot Spring 1440 ppm

..Fluid Chemistry: (See following Table)

..Estimated Reservoir Heat Content:

Alvord Hot Springs - .5 $.51018 \mathrm{cal}$. Mickey Hot Springs - $1.4 \times 1018$ cal. Hot Lake Springs $-1.2 \times 10^{18}$ cal.

If Hot Lake, Mickey and Aivord are one large system with temperatures as at Mickey, the heat content would be $30 \times 10^{18}$ cal., however, three separate systems is the preferred model.

(1)

..Estimated Electric Energy Potential:

310 MWe (DOE Division of Geothermal Energy)

..Subsurface Area of Reservoir:

Alvord Hot Springs - $3 \mathrm{~km}^{2}$ estimated Mickey Hot Springs - $6 \mathrm{~km}^{2}$ estimated Hot Lake Springs $-6 \mathrm{~km}^{2}$ estimated 
.Chemical Analysis of Hot Springs:

\begin{tabular}{|c|c|c|c|c|}
\hline & $\begin{array}{l}\text { A7vord Hot Spring } \\
\text { (Indian Spring) }\end{array}$ & $\begin{array}{l}\text { Mickey } \\
\text { Hot Springs } \\
\end{array}$ & $\begin{array}{l}\text { Hot (Borax) } \\
\text { Lake Spring }\end{array}$ & $\begin{array}{l}\text { Unnamed Hot Spring } \\
\text { Near Trout Creek }\end{array}$ \\
\hline ecific conductance & 4,590 & 2,490 & 2,020 & 1,168 \\
\hline $\begin{array}{l}\text { Silica } \\
\text { Calcium } \\
\text { Magnesium } \\
\text { Sodium } \\
\text { Potassium } \\
\text { Lithium } \\
\text { Bicarbonate } \\
\text { Carbonate } \\
\text { Sulfate } \\
\text { Chloride } \\
\text { Flouride } \\
\text { Boron } \\
\text { Temperature }\left({ }^{\circ} \mathrm{C}\right) \\
\text { pH } \\
\text { Flow rate }(1 \mathrm{pm})\end{array}$ & $\begin{array}{c}120 \\
13 \\
2.2 \\
960 \\
69 \\
2.1 \\
1,196 \\
1 \\
220 \\
780 \\
10.2 \\
30 \\
76 \\
6.73 \\
500\end{array}$ & $\begin{array}{l}200 \\
0.9 \\
0.1 \\
550 \\
35 \\
1.1 \\
774 \\
11 \\
230 \\
240 \\
16 \\
10.5 \\
73 \\
8.05 \\
100\end{array}$ & $\begin{array}{l}160 \\
14 \\
0.3 \\
450 \\
28 \\
0.5 \\
374 \\
4 \\
434 \\
250 \\
7.2 \\
15 \\
96 \\
7.30 \\
200\end{array}$ & $\begin{array}{c}105 \\
18 \\
0.8 \\
270 \\
10.8 \\
0.68 \\
439 \\
1 \\
204 \\
24 \\
12.8 \\
0.89 \\
52 \\
6.77 \\
200\end{array}$ \\
\hline
\end{tabular}

Units $\mathrm{mg} / 1$

Location: Alvord Hot Spring - Sec. 33, T.34S., R.34E.

Mickey Hot Spring - Sec. 13, T.33S., R.35E.

Hot Lake Spring - Sec. 15, T.37S., R.33E.

Unnamed Hot Spring- Sec. 16, T.39S., R.37E.

(Trout Creek)

(3) (21) 


\section{LAND OWNERSHIP AND LEASING}

\section{SITE: ALVORD KGRA}

. Total KGRA acres: 176,835

Federal Tand is managed by the Burns District of BLM.

..Approximate Ownership:

$$
\begin{array}{lr}
\text { Public land - public minerals } & 106,438 \text { acres } \\
\text { State land - state minerals } & 5,360 \text { acres } \\
\text { Private land - private minerals } & 63,441 \text { acres } \\
\text { Private land - public minerals } & 1,134 \text { acres }
\end{array}
$$

(Mineral rights in portions of these areas is undertermined)

..Land Leased in KGRA:

$$
\begin{array}{ll}
\text { Federal } & 23,661 \text { acres } \\
\text { State } & 2,800 \text { acres } \\
\text { Private } & 41,500 \text { acres (approximately) }
\end{array}
$$

..Highest Price Lease: $\quad \$ 10.56 /$ Acre

.\$/Acre

7.17

6.57

2.07

5.38

2.07

10.56

2.13

4.47

2.17

6.03

5.25

2.53

\section{Lessee.}

Al-Aquitaine

Al-Aquitaine

Republ ic Geothermal

Republ ic Geothermal

Republ ic Geothermal

Republ ic Geothermal

Republic Geothermal

Mapco

Mapco

Mapco

Getty $0 i 1$

Supron Energy
Federal (Acres)

2560

2560

1920

640

2560

2560

2402

2397

1920

2016

2126

2560

..Leases on State Land:

\section{Lessee}

Max Millis

Intercontinental Energy

Intercontinental Energy

Thermogenics

Thermogen ics
Acreage

1280

640

1280

240

640 
.. Leases on Private Land:

\section{Lessee}

Anadarko Production

Union 0 i1

Getty 0 i 1

Standard 0 il
Acreage

(Approx.)

27,594

11,014

2,729

160

..Lease sales:

Held $5 / 22 / 75,5 / 29 / 75,6 / 5 / 75$.

A lease sale scheduled to $10 / 78$ was postponed due to pending legal matters.

.. Number of Bids Rejected: 6

.. Summary of Leasing Status and Needs:

Three competitive lease sales were held in 1975. Of the 44 units that were offered, 14 were leased with a total of 23,661 acres.

The Bureau of Land Management rejected six bids from Union and Getty 0il Companies for being too low. Both cases were appealed to the Department of Interior's Board of Land Appeals. The board rejected Getty's appeal in 1976. Union's case was heard in December 1977 and as a result an order was issued requiring the solicitor to consult with the U.S. Geological Survey and provide more information to the board. The case is still pending. Reoffering of land does not seem likely until this case is resolved and the BLM completes a roadless area study.

\section{..Present Development Status:}

Alvord Hot Springs are used for bathing.

Active exploration has been taking place for several years. 


\section{INSTITUTIONAL CONSIDERATIONS}

SITE: ALVORD KGRA

..Institutional Requirements:

The area is zoned agricultural (A-1) which al lows exploration activities and power generating plants.

Exploration and development activities may require a conditional use permit from Harney County in certain areas.

Agency and Public Attitudes:

As indicated by the leasing of private land, locals are in favor of geothermal exploration. Approximately 41,500 acres or 64 percent of the private land within the KGRA is under lease. Reportedly annual rental rates vary from $\$ .25$ to $\$ 2.00$ per acre.

Harney County Planning Committee sent a letter to the BLM in 1977 stating no objections to an environmental analysis of 14,225 acres for exploration and possible development of geothermal energy.

Residents of the area appear to favor geothermal development as long as it is compatible with existing land uses and does not significantly modify the natural landscape.

..Status of Requirements:

An Environmental Analysis Report addressing geothermal leasing in the Alvord Desert was issued by the Burns District BLM Office in January 1975.

The Bureau of Land Management is conducting a roadless area study in 1978 and 1979 which includes the Alvord Valley.

Sierra Club and the High Desert Study Group filed suit against the BLM claiming that the environmental analysis was not sufficient. They sought to halt all leasing until a full EIS had been completed. The case was heard in the 9th Circuit Court in January 1978. Judge Burns denied a prel iminary injunction barring leasing. A final decision is still awaited. In the meant ime the BLM is required to submit monthly reports to the Judge listing details of all access to the area. In late 1978 40 monthly reports had been submitted.

Reoffering and leasing of additional units cannot take place until the legal cases are resolved and the BLM has completed the roadless area study. 


\section{ENVIRONMENTAL FACTORS}

\section{SITE: ALVORD KGRA}

..CLIMATE: Semi-arid to arid

..Prevailing Winds: West. Strong winds common March to June.

..Precipitation (Annual): $20 \mathrm{~cm}$

.Average Temperature $\quad 9.4{ }^{\circ} \mathrm{C}\left(48.90^{\circ}\right)$

Minimum: $1.1^{\circ} \mathrm{C}\left(34.1^{\circ} \mathrm{F}\right)$

Maximum: $17.50^{\circ} \mathrm{C}\left(63.6^{\circ} \mathrm{F}\right)$

-.Relative Humidity (Seasonal Peaks)

Summer: $\quad 30-40$ percent

Winter: $70-80$ percent

..AIR QUALITY:

No monitoring stations are maintained in the area.

Dust from wind storms is the only contaminant of note.

..WATER QUALITY:

No information is available on-groundwater quality. Most of the water in the valley away from the fresh water recharge areas is saline and has a high boron concentration.

The basin and lake beds are strongly alkaline, a form of natural pollution.

South of Alvord Lake near Hot Lake, several thousand acres are encrusted with a layer of sodium borate several inches thick, which also contains sodium carbonate, sodium sulphate, sodium
chloride and other salts. (37)

..NOISE:

Ambient noise levels are low with most noise coming from traffic
along roads. 


\section{ENVIRONMENTAL FACTORS}

(CONTINUED)

SITE: ALVORD KGRA

..BIOLOGICAL

..Dominant Flora:

There are two major plant communities in the area: the desert shrub type in the valley and big sagebrush association above 1,280 meters

The desert shrub zone is extremely fragi le and subject to rapid deterioration by any disturbing influence.

Desert shrub zone: sagebrush, greasewood, saltbush, cheatgrass, saltgrass, and others.

Big sagebrush zone: sagebrush, bitterbrush, bluebunch wheatgrass, Idaho fescue, patches of juniper and alder, forbs and others.

..Dominant Fauna:

Mule deer, antelope, feral horses, coyotes, jackrabbits, rodents, nine species of lizards, seven species of snakes, sandhili cranes, waterfowl, shorebirds, marshbirds and others.

...Endangered Species:

Fauna:

Golden eagles

Oregon Endangered Species List:

Alvord Chub

Alvord Cutthroat trout

Collared lizard

Leopard lizard 


\section{TRANSPORTATION AND UTILITIES}

\section{SITE: ALVORD KGRA}

\section{..Utility or Energy Transmission Corridors and Facilities}

A $115 \mathrm{kv}$ transmission line crosses the valley from roughly east to west near Fields.

A lesser line parallels the north-south county road with spurs to ranches and water wells.

Harney Electric Cooperative provides electrical service to ranches within the area and to the community of fields (in service since 1962).

\section{..Transporation Corridors or Facilities}

A gravel county road traverses the west side of the Alvord Valley connecting the communities of Fields, Andrews and Denio, Nevada. Numerous unimproved roads crisscross the area.

The Steens Scenic Loop Road extends northwest from Fields, through the Steens Mountain, north to Frenchglen and Burns. An unimproved road eastward by way of Whitehorse Ranch provides access to U.S. Route 95 to Burns Junction and McDermitt, Nevada. The county road intersects State Route 78 which goes to Burns. The distance from Fields to Lakeview is about $232 \mathrm{~km}$ by way of Denio and U.S. Route 140. A landing strip is located at Fields. 


\section{POPULATION}

\section{SITE: ALVORD KGRA}

\section{..General Description of Population}

The Alvord Valley is one of the most remote areas in Oregon.

Only a few ranchers inhabit the area, there are no paved roads and the closest incorporated town is over $160 \mathrm{~km}$ distance.

The community of Fields has a year round population of 11 and boasts a post office, a combination cafe-motel-gas station-general store, and a schoolhouse. There is also a schoolhouse at Andrews, population less than 10. Fewer than 10 children attend the two schools. Upon reaching high school age, students attend a public boarding school in Crane.

The owners and employees of the approximate nine ranches headquartered in the area comprise almost the total population of the KGRA.

Total population of the KGRA and closely adjacent area numbers less than 50 .

Burns, about $200 \mathrm{~km}$ northwest of Fields, is the closest service center for residents of the Alvord Valley.

...Economics

..Present Land Use:

The economy of the area is based almost exclusively on livestock production and grazing.

..Future Land Use:

Ranching and livestock grazing are likely to remain as the primary land use given the physical characteristics and limitations of the land. 
Basin and Range Region References

(1)

White, D. E. and Williams, D. L., eds., 1975, Assessment of Geothermal Resources of the United States - 1975: U.S. Geological Survey Circular 726.

(2) Bureau of Land Management, 1975, Environmental Analysis Record for Proposed Geothermal Leasing - Klamath Basin, Lakeview and Medford Districts.

(3) U.S. Geological Survey, Geothermal Resources File (Geotherm) Revision 8, Computer Data File.

(4) Lund, John W., 1978, Geothermal Hydrology and Geochemistry of Klamath Fails, Oregon Urban Area: U.S. Geological Survey Grant No. 14-08-0001-G-291.

(5) Sammel, E. A., 1976, Hydrologic Reconnaissance of the Geothermal Area near Klamath Falls, Oregon: U.S. Geological Survey Water Resources Investigation Open File Report WRI 76-127.

(6) Bureau of Land Management, Geothermal Leasing Serial Register, State Office, Portland, Oregon.

(7) O'Conne11, M. F. and Kaufmann, R. F., 1976, Radioactivity Associated with Geothermal Waters in the Western U.S. Basic Data: U.S. Environmental Protection Agency, Office of Radiation Programs, Las Vegas, Nevada.

(8) Lienau, Paul J., Lund, John W., Utilization and Economics of Geothermal Space-heating in Klamath Falls, Oregon: Geo-Heat Utilization Center, Oregon Institute of Technology.

(9) Lund, John W., Geo-Heat Utilization Center, Personal Commun ication, $11 / 16 / 78$.

(10) Lienau, Paul, Principal Investigator, 1978, Geothermal Energy for Agri-Business for Klamath and Western Snake River Basins, Oregon: Geo-Heat Utilization Center, Oregon Institute of Technology.

(11) Culver, G. Gene, and Reistad, Gordon, M., 1978, Testing and Modeling of Downhole Heat Exchangers in Shal low Geothermal Systems: Transactions, Geothermal Resources Council Annual Meeting. 
(12) Bowen, R. G., and Peterson, N. V., 1970, Thermal Springs and Wells in Oregon: Oregon Department of Geology and Mineral Industries Miscellaneous Paper 14.

(13) U.S. Geological Survey, Known Geothermal Resource Areas as Classified by the Indicated Area Geologists Western and Central Regions: U.S. Geological Survey, Unnumbered Paper.

(14) U.S. Forest Service, 1978, Draft Environmental Statement Timber Management Plan, Fremont National Forest.

(15) Williams, F., et. al., 1977, Site-Specific Analys is of Geothermal Development-Data Files of Prospective Sites: The Mitre Corporation, v. 111.

(16) Waggoner, Marjorie, Personal Communication, Bureau of Land Management, $3 / 10 / 78$.

(17) Berg, J. W., Jr., and Thiruvathukal, J. W., 1967, Complete Bouger Gravity Anomaly Map of Oregon: Oregon Department of Geology and Mineral Industries Map GMS 4-b.

Port land General Electric, 1976, Prospects for Electric Power from Geothermal Energy: Internal Report to Management:

Bowen, R. G., Blackwe11, D. D. and Hull, D., 1975, Geothermal Studies and Exploration in Oregon: Oregon Department of Geology and Mineral Industries Open File Report 0-75-7.

(20) Bonneville Power Administration, 1971, Pacific Northwest Transmission System Map.

(21) Mariner, R. H., Rapp, J. B., Willey, L. M. and Presser, T. S., 1974, The Chemical Composition and Estimated Minimum Thermal Reservoir Temperatures of Selected Hot Springs in Oregon: U.S. Geological Survey Open File Report.

(22) Crocker, Marvin, Personal Communication, Fremont National Forest, $6 / 19 / 78$.

(23) Peterson, N. V., and McIntyre, J. R., 1970, The Reconnaissance Geology and Mineral Resources of Eastern K1amath County and Western Lake County, Oregon: Oregon Department of Geology and Mineral Industries Bul let in 66.

(24) Meyer, Jack, and Hook, John, 1978, Geothermal Study of Lakeview, Lake County, Oregon: Unpublished Report. 
(25) Gulf 0il Company, Favell-Utley Well No. 1-ST: Oregon Department of Geology and Mineral Industries Drilling Records.

(26) Groh, E. A., 1966, Geothermal Energy Potential in Oregon: Ore Bin, V. 28, N. 7 .

(27) Bowen, R. G., Blackwell, D. D. and Hull, D. A., 1977, Geothermal Exploration Studies in Oregon: Oregon Department of Geology and Mineral Industries Miscellaneous Paper 19.

(28) Bureau of Land Management, 1976, Summer Lake Environmental Analysis Report for Proposed Geothermal Leasing: Lakeview District.

(29) Phillips, K. N. and VanDenburgh, A. S., 1971, Hydrology and Geochemistry of Abert, Summer and Goose Lakes and other Closed Bas in Lakes in South-central Oregon: U.S. Geological Survey Professional Paper 502-B.

(30) Bureau of Land Management, 1975, Crump Geyser Environmental Analysis Report for Proposed Geothermal Leasing: Susanville, California and Lakeview, Oregon Districts.

(31) Walker, G. W. and Repenning, C. A., 1965, Reconnaissance Geologic Map of the Adel Quadrangle, Lake, Harney and Malheur Counties, Oregon: U.S. Geologicai Survey Miscellaneous Geologic Investigation Map I-446.

(32) Donath, F. A., 1962, Analysis of Basin-Range Structure, South-Centrai Oregon: Geologic Society of America Bulletin, V. 73, N. 1 .

(33) Lawrence, R. D., 1976, Strike-S1 ip Faulting Terminates the Basin and Range Province in Oregon: Geological Society of America Bulletin, V. 87.

(34) Plouff, D. and Conradi, A., Jr., 1975, Gravity and Magnetic Profiles and Maps, Crump Geyser Area, Oregon: U.S. Geological Survey Open File Report 75-346.

(35) Oregon Department of Geology and Mineral Industries, Well Drilling Log.

(36) Bureau of Land Management, 1975, Environmental Analys is Report - Alvord Desert Geothermal Leasing Program: Burns District.

(37) Libbey, F. W., 1960, Boron in Alvord Valley, Harney County, Oregon: Ore Bin, V. 22, N. 10. 
(38) Griscom, A. and Conradt, A., 1975, Principal Facts and Prel iminary Interpretation for Gravity Profiles and Magnetometer Profiles in the Alvord Valley, Oregon: U.S. Geological Survey Open File Report 75-293.

(39) Long, C. L. and Gregory, D. I., 1975, Audio-Magnetotelluric Apparent Resistivity Maps for Parts of Harney County, Oregon: U.S. Geological Survey Open File Report 75-297.

(40) Sass, J. H., Galanis, S. P., Munroe, R. J. and Urban, T. C., 1976, Heat Flow Data from Southeastern Oregon: U.S. Geological Survey Open File Report 76-217.

(41) Bowen, R. G., Blackwell, D. D. and Hull, D. A., 1977, Geothermal Exploration Studies in Oregon: Oregon Department of Geology and Mineral Industries Miscellaneous Paper 19.

(42) Bowen, R. G., Blackwel1, D. D. and Hul 1, D. A., 1975, Geothermal Studies and Exploration in Oregon: Oregon Department of Geology and Mineral Industries Open File. Report. 


\section{HIGH LAVA PLAINS GEOTHERMAL PLANNING REGION}

The High Lava Plains extend from the foot of the Cascade Mountains to the eastern border of the Harney Basin. The region is bounded on the north by the Blue Mountains and on the south by the Basin and Range province.

The landscape is characterized by a smooth surface plain of lava flows marked in places by cinder cones and other volcanic surface features. Elevation of the plain is moderately high but the local relief is generally low. The region is the driest in Oregon and drainage is not well developed. Closed drainage systems such as Harney Basin, and playa lakes are common. Overall, the region is the youngest and least eroded area in Oregon.

Population in the region is concentrated in the Bend and Burns areas. Outside these communities, population levels are low. Economic activities are centered on the forest products industry, livestock and recreation.

The U.S. Geological Survey has classified two portions of the region as Known Geothermal Resource Areas: Newberry Crater and Burns Butte. The potential of geothermal development in these areas is discussed in the following chapter. In addition, a narrative overview of the Brothers fault zone, a major structural lineament which crosses the region, is presented to provide a better understanding of the geothermal potential of the region. 
SITE: NEWBERRY CRATER KGRA, OREGON 


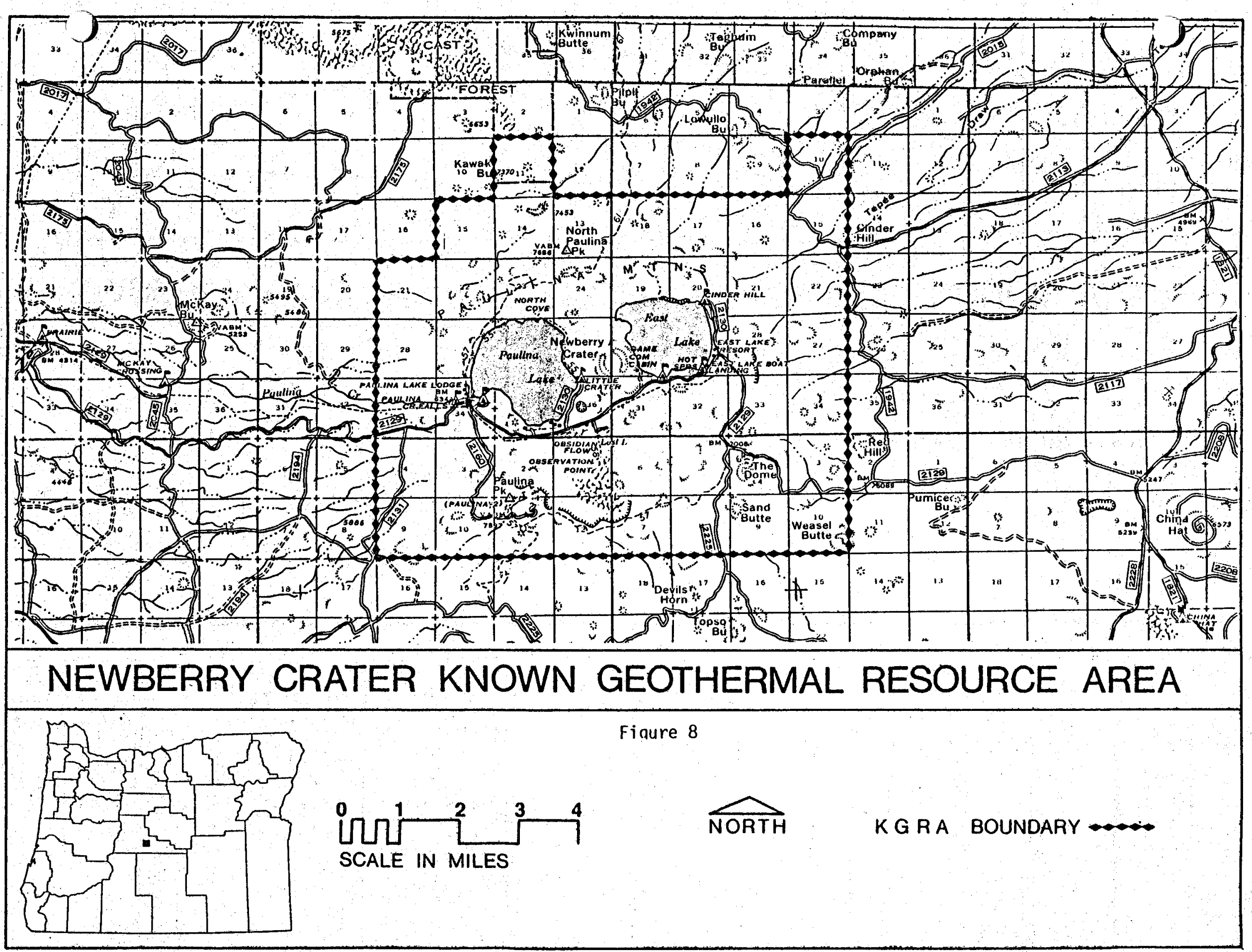




\section{NEWBERKY CRATER}

The Newberry Crater KGRA covers 31,284 acres in Deschutes County in central Oregon, T.2IS., R.I3E., W.M. The KGRA is centered on Newberry Volcano, a broad Quaternary shield volcano rising $1,200 \mathrm{~m}$. above the lava plains. Two large lakes, East and Paulina, occupy the summit caldera. The floor of the crater is marked by young volcanic features such as cinder cones, tuff rings and obsidian flows. Elevations range from $1,315 \mathrm{~m}$. at Paulina Creek to $2,434 \mathrm{~m}$. at Paulina Peak and vegetation ranges from sagebrush and juniper to lodgepole and ponderosa pine forest according to elevation.

Newberry Crater has been classified as a KGRA based primarily on the geology of the area. It is an area of young silicic volcanism, and lies between two major regional fault systems: High Cascades and Brothers fault zone. The youngest dated silicic rock is 1,300 years and recent activity along the faults is evident (Peterson and Groh, 1969). Nuch of the shield volcano was developed during Pleistocene times and although the date of caldera formation is uncertain, flows and pyroclastics are not covered by Mazama ash and therefore are less than 6,600 years old (Higgins and Waters, 1967).

Uncierground heat sources are indicated by the hot springs situated along the northeast shore of Paulina Lake and the south shore of East Lake. Temperatures of the springs are fairly low, $57.3^{\circ} \mathrm{C}$ and $62^{\circ} \mathrm{C}$ respectively, but these readings are influenced by cooler water in the lakes.

A heat flow and temperature gradient study also suggests the existence of a potentially valuable geothermal resource. Although measurements were inconclusive due to shallow well depths and the effects of migrating groundwater, still Newberry Volcano was one of three areas near the Brothers fault zone that was identified as being especially promising for geothermal development.

A U.S. Geological Survey report (MacLeod and others, 1975) suggests that Newberry Volcano has significant potential based on the probability of a shallow heat source situated airectly under the caldera. The U.S.G.S. is conducting an on-going temperature gradient drilling program including holes within the caldera and on the flanks of the volcano. 
Energy needs in the immediate area which could be satisfied with non-electric applications of geothermal resources are limited. Except for the families operating the two resorts the area is essentially uninhabited. Extensive recreation use is made, primarily day-use and outdoor activities which do not require structured facilities.

However, the Bend area is one of the fastest growing in the state. Bend, about $40 \mathrm{~km}$ north of Newberry Volcano; is the largest urban center east of the Cascade Mountains. The estimated 1978 population is 17,100. Timber production and recreation are two of the most important aspects of the area's economy.

A large part of the growth in Deschutes County is occurring in the area between Bend and LaPine which is about $20 \mathrm{~km}$ southeast of Newberry Crater. Niuch of the development is in the form of subdivisions to provide housing for year-round residents and recreationists. Reportedly, 15,000 undeveloped lots have been sold in the Bend area.

Recreation is a year-round business. In the winter large numbers of people are attracted to the area for skiing at Mt. Bachelor and snow-mobiling and cross-country skiing in the Deschutes National Forest. In the summer the high lakes country and forest areas are heavily used for fishing, hiking, comping and other outdoor activities.

Clearly there could be a large demana for geothermal energy to be utilized in the wood products industry and for district space heating if a resource were readily available. The problems are: distance from the site and insufficient cata on the true nature of the resource. If a resource suitable for non-electric applications was discovered within the crater, pumping hot water up and out of the volcano could prove too costly to justify a project in the Bena area. The tlanks of the volcano appear to offer some potential for geothermal development but less than within the volcano itself.

The potential for electric generation from geothermal reservoirs at Newberry Volcano is not well known since the resource has yet to be defined. But several major oil companies, who are assumed to be interested in power production, have filed non-competitive lease applications on a considerable portion of land in and arouna Newberry Volcano. Lease opplications in total, including private companies and individuals, cover about 264,000 acres in a $9-11 \mathrm{~km}$. radius of the volcano. 
Processing of lease applications awaits completion of an Environmental Analysis Report addressing non-competitive leasing in the Newberry area. The Deschutes National Forest is currently preparing the document which has a target date of early 1979 for publication in draft form. A complete Environmental Impact Statement (EIS) will be compiled for considering competitive leasing within Newberry Crater. The EIS is planned for release in fiscal year 1980. As well, the U.S. Geological Survey has tentatively scheduled a December 1980 lease sale for tracts in the KGRA.

The leasing situation is not the only barrier to geothermal exploration and development at Newberry Crater. Environmental considerations are also a controlling factor. Uf primary concern are the area's geologic uniqueness, roadless qualities, recreational opportunities and scenic values.

In 1975 the Uregon Legislature passed House Joint Resoluation 31 which directed the Nuclear and Thermal Energy Council (now the Energy Facility Siting Council) to designate 39,000 acres, including Newberry Crater and the Lava Cast Forest geologic interest area, as unsuitable for thermal power plants. Environmental groups have also expressed concern about potential adverse impacts from geothermal development at Newberry Crater.

It seems evident that any geothermal development at Newbery Crater will have to be compatible with environmental factors and conform to existing land uses. Otherwise state regulatory bodies and public pressure will not likely preclude such activities. 


\section{SITE DATA SUMMARY}

\section{SITE: NEWBERRY CRATER KGRA}

..Physical Reservoir Date

.. Temperature ${ }^{\circ} \mathrm{C}$

Surface: $62^{\circ} \mathrm{C}$

..Site Land Status

$$
\begin{aligned}
& \text { Total Acres } \\
& \text { Total Acres Lease - }
\end{aligned}
$$

..Geothermal Development Status:

A temperature gradient drilling program was begun in 1977 by the U.S. Geological Survey and is expected to continue into 1979.

..Local and State Attitude Toward Geothermal Development:

Highly sensitive.

House Joint Resolution 31 (1975) directed the Nuclear and Thermal Energy Council to designate 39,000 acres including Newberry Crater and Lava Cast Forest as unsuitable for thermal power plants.

..Land Use and Population:

The crater is essentially uninhabited, but is heavily used for recreation and timber production.

Deschutes County area is one of the most rapidly expanding regions in Oregon. Timber production, recreation, agriculture and livestock raising are the primary economic activities. 
SITE LOCATION AND PHYSICAL DESCRIPTION

SITE: NEWBERRY CRATER KGRA

.. Latitude: 43044 ! N

..Longitude: 121014 ! W

..Rectilinear: Secs. $11,13,14,15,21-28,33-36$, T.21S., R.12E; W.M.

Secs. $1-4,9-12$, T.22S., R.12E.;

Secs. $10,15-22,27-34$, T.21S., R. 13E.;

Secs. 3-10, T.22S., R.13E.

.. County: Deschutes

..Adjacent Counties: Lane, Jefferson, Crook, Lake, Klamath

..Map Reference: U.S.G.S. topographic - Paulina Peak

AviS - Crescent 1:250,000

.. Topography

Newberry Volcano is a broad shield volcano, elevation 2,440 meters, rising 1,219 meters above the basalt plateus of central Uregon. The volcano is marked by a large caldera which contains East and Paulina Lakes. The lakes are separated by cinder cones and a large obsidian flow. Elevations at the iakes are: 1,930 m. $(6,331 \mathrm{ft}$.$) Paulina Lake and 1,942 \mathrm{~m} .(6,371 \mathrm{ft}$.$) at East$ Lake. The overall terrain is varied ranging from rolling topography with many cinder cones and lava fields to steep bluffs. Elevations range from $1,315 \mathrm{~m}$. $(4,314 \mathrm{ft}$. $)$ on Paul ina Creek to $2,434 \mathrm{~m} .(7,985 \mathrm{ft}$. $)$ at Paulina Peak. Paul ina Creek drains the caldera to the west.

-.Present Land Use: Heavily used recreation and timber. production area.

. Future Land Use Plans:

Future land use is expected to continue recreation and forest products focus. 
..Aesthetics:

Unique attractions within the area give a high aesthetic value. Paulina Peak is a significant viewpoint. Hiking trails and fishing in the lakes within the crater are popular recreational activities. Young volcanism has resulted in a variety of interesting geologic features such as: lava tubes, obsidian flows, pumice deposits, cinder cones and ash flow sheets.

..Historical/Archaeological Significance:

Three known sites have been nominated to the National Register of Historic Places. Others may be present. Charcoal Cave Pipeline Archaeological Site Paulina Lake Archaeological Site 


\section{GEOLOGICAL/GEOPHYSICAL DESCRIPTION}

\section{SITE: NEWBERRY CRATER KGRA}

\section{..Geologic Description:}

Newberry Volcano is a broad shield volcano rising about 1,200 meters above the basalt plateus of central Oregon. The basal diameter is approximately $32 \mathrm{~km}$.

The volcano has a summit caldera which contains two large lakes, Paulina and East Lakes. The lakes are separated by obsidian flows, pumice cones and basaltic tuff rings. Paulina Creek, flowing west to the Deschutes River, is the only surface drainage for the crater.

The caldera is an oval depression in the summit of Newberry Volcano about $8 \mathrm{~km}$ long and $6.4 \mathrm{~km}$ wide. It was formed as lavas beneath the volcano were erupted withdrawing support which caused subsidence along concentric faults. These ring fractures are marked by cinder and spatter cones.

Cinder cones and small vents numbering more than 150 are also located on the flanks of the volcano, primarily on the southeast and northwest sides. They generally trend N.250 W.

Numerous northwest-trending faults are apparent on Newberry Volcano itself and within the crater. The most recent and obvious of these is a zone of en echelon faults trending N.300 $W$. beginning in the caldera at the fissure at East Lake and extending about $24 \mathrm{~km}$ to slightly north of Lava Butte. At least eight separate basaltic lava flaws have occurred along this "northwest rift zone". (Peterson and Groh).

Much of the shield volcano was developed during Pleistocene times with eruptions continuing until a few centuries ago. The early flows were basalt which were followed by thick sheets of rhyolite and later with basaltic ash. After the flanks of the volcano had reached their maximum height, basaltic eruptions removed support beneath the summit causing its collapse, thereby forming Newberry Crater. 
A variety of features including pumice cones, rhyolite domes, basaltic tuff rings and obsidian flows were formed in the crater after its creation. Most of these landforms are less than 12,000 years old. The Big Obsidian Flow southeast of Paulina Lake is the youngest feature with an age of approximately 1,200 years.

Newberry Voicano is located between two regional fault systems; the north-sourth trending High Cascades and the Brothers fault zone. The Brothers fault zone extends from the Steens Mountains in southeast Oregon to near Bend generally trending $\mathrm{N} .60^{\circ} \mathrm{W}$. Near Newberry Volcano the zone appears to take a turn and head in a N. $35^{\circ} \mathrm{W}$ trending direction towards Sisters. The implications of these tectonic features in regards to their association with Newberry Volcano is not well understood. $(4)(7)(8)(9)(10)$ 


\section{RESERVOIR CHARACTERISTICS}

SITE: NEWBERRY CRATER KGRA

..Reservoir Temperature

.. Surface: $62^{\circ} \mathrm{C}(2)$

..Subsurface: No estimates available

..Geochemical - Chemical concentrations in the hot springs water is very similar to those of normal groundwater, thereby preventing the application of geothermometry techniques.

Waring 1 ists the following spring temperature:

$$
\text { East Lake }-61^{\circ} \mathrm{C}\left(141^{\circ} \mathrm{F}\right)
$$

Paul ina Lake - $21^{\circ} \mathrm{C}\left(70^{\circ} \mathrm{F}\right)$

...Fluid Chemsitry:

East Lake Hot Springs

Specific conductance (micromhos) 396

Silicia

Calcium

Magnes ium

16

Sodium

32

Potassium

Lithium

3.8

Sulfate

.01

Chloride

58

Flouride

0.4

Boron

(Units $\mathrm{mg} / \mathrm{l}$ )

0.2

.93

Composition of Escaping Gases (in volume percent)

Carbon Dioxide

56

Nitrogen

30

Methane

9

Oxygen and Argon

6

East Lake Hot Springs - T.21S., R.13E., Section 29 


\section{LAND OWNERSHIP AND LEASING}

SITE: NEWBERRY CRATER KGRA

..Land Ownership - Federal ownership managed by the Deschutes National Forest.

$$
\begin{aligned}
& \text { TOTAL AREA (KGRA) - } 31,284 \text { acres } \\
& \text { FEDERAL }
\end{aligned}
$$

..Land Leased - FEDERAL (Acres) - 0

.. Highest Prices Leases (Dollars/Acre) - N/A

..Lessee - N/A

..Tentative Lease Sale Dates: $\quad 12 / 80$

.. Number of Sales Offered But No Bids: N/A

.. Number of Bids Rejected (Resulting in No Lease): N/A

.. Summary of Leasing Status and Needs:

An environmental impact statement covering Newberry Crater must be completed before competitive leasing can take place. Approximately 117 non-competitive lease applications have been filed on 264,000 acres in a 9-11 km radius of the rim of Newberry Crater. Processing of these applications should begin in 1979 following approval of the EAR for non-competitive leasing. Lease applicants include Phillips Petroleum, Union 0il, Chevron, California Geothermal, Sunoco and others. 


\section{GEOTHERMAL DEVELOPMENT STATUS}

\section{SITE: NEWBERRY CRATER KGRA}

..Present Development Status: There are no current developments.

Industry interest in exploring for geothermal resources, as evidenced by filing of lease applications, is extremely high.

..Exploration Activities:

The U.S. Geological Survey has selected three sites; one in the crater, one on the southwest side of the crater and another on the northeast flank of the crater, for drilling temperature gradient holes. The northeast location was drilled in 1977 to a depth of 384 meters. A stuck drill pipe prevented further drilling. In September 1978 the hole inside the crater was drilled to 304 meters. Reported bottom hole temperature shortly after drilling ceased was about $90^{\circ} \mathrm{C}$. (6) It is expected that the well will be drilled to a depth of 609 meters in 1979. Dr. Ed Sammel is directing the project for the U.S.G.S.

The Oregon Department of Geology and Mineral Industries measured temperature gradients in five drilled holes and four water wells near Newberry Volcano and Bend. None of the sites were on the volcano. Data from these wells are available in the cited references.

One well located in T.21S., R.11E., Section 25 west of Paulina Lake had an average gradient from 12.5-35 meters of $39.6^{\circ} \mathrm{C} / \mathrm{km}$. The gradient increased with depth and was found to be $650 \mathrm{c} / \mathrm{km}$ from 27.5-35 meters. The estimated heat flow is $2.4 \mathrm{HFU}$ (Heat flow Units). This value is of low reliability because of the shallow depth of the hole and possible effects of groundwater migration.

The Brothers Fault Zone heat flow study suggests that Newberry Volcano is one of three areas along the lineament which appear particularly promising for geothermal development. Heat flow measurements in the area are not reliable in holes less than 152 meters due to groundwater effects. The study states that holes in basalt will need to be at least 300 meters in order to obtain reliable data.: The need for further testing seems apparent. (5) (11)

-.Projected or Planned Exploration:

Further temperature gradient drilling by the U.S.G.S. in 1979. 


\section{INST ITUT IONAL CONSIDERATIONS}

\section{SITE: NEWBERRY CRATER KGRA}

..Institutional Requirements:

Oregon House Joint Resoluation 31 (1975) directed the Nuclear and Thermal Energy Council (now the Energy Facility Siting Council) to designate Newberry Crater, Lava Cast Forest and contiguous roadless areas as unsuitable for thermal power plants. This area covers 39,000 acres. Exploration can apparently take place outside the 11,000 acres of the caldera.

.. Agency and Public Attitudes:

Attitudes, as expressed by Oregon Legislature, are negative towards geothermal development in Newberry Crater.

..Status of Requirements (i.e., EIA/EIS Requirements):

An Environmental Analysis Report covering geothermal leasing for the Ft. Rock Ranger District was issued in October 1975. This EAR did not address geothermal leasing in Newberry Crater. The Deschutes National Forest is planning to do an Environmental Impact Statement for geothermal leasing in Newberry Crater. Release date is targeted for fiscal year 1980 . An Environmental Analysis Report addressing non-competitive leasing in the Newberry area is being compiled by the Forest Service. A draft copy should be available in early 1979.

Two areas totally surrounding East and Paul ina Lakes on Newberry Volcano are being examined by the U.S. Forest Service as part of the RARE II process for possible inclusion in the National Wilderness Preservation System. As classified in the Oregon Supplement to the Draft Environmental Statement - Roadless Area Review and Evaluation, neither area has producing, proven or possible geothermal resources.

The areas are as follows:

\begin{tabular}{|c|c|c|c|}
\hline Area & $\begin{array}{l}\text { Area } \\
\text { Code } \\
\end{array}$ & $\begin{array}{c}\text { Administrative } \\
\text { District }\end{array}$ & $\begin{array}{r}\text { Total } \\
\text { Acreage } \\
\end{array}$ \\
\hline North Paulina & 6196 & $\begin{array}{l}\text { Deschutes National Forest } \\
\text { Ft. Rock Ranger District }\end{array}$ & 22,200 \\
\hline outh Paulina & 6197 & Ft. Rock Ranger District & 10,20 \\
\hline
\end{tabular}


ENVIRONMENTAL FACTORS

SITE: NEWBERRY CRATER KGRA

.. CLIMATE

..Precipitation (Annual): $64-76 \mathrm{~cm}$

Average mid winter snow depth is about 2-3 -meters. Snow depth in Newberry Crater has been measured as high as 5 meters.

..Average Temperature: $8.6^{\circ} \mathrm{C}\left(47.5^{\circ} \mathrm{F}\right)$

Minimum: $-59^{\circ} \mathrm{C}\left(-25^{\circ} \cdot \mathrm{F}\right)$

Maximum: $\quad 40.5^{\circ} \mathrm{C}\left(105^{\circ} \mathrm{F}\right)$

..AIR QUALITY: Generally high due to remoteness from industrial and population centers.

..WATER QUALITY:

Quality is high but there is hardly any surface water due to the permeability of volcanic materials at the surface and subsurface. Paulina Creek flowing west to the Deschutes River from Paulina Lake is the only stream in the crater.

.. NOISE: Low levels.

. BIOLOGICAL

.Dominant Flora:

Mixed lodgepole pine, ponderosa pine and white fir forest assocation.

Non-forestêd areas - Juniper, sagebrush and rảbbit brush.

. Dominant Fauna: Mule deer, Black bear, cougar, coyote, squirrel, procupine, pocket gophers and others. Numerous bird species.

Big game such as deer, antelope, elk and bear may water within the crater, but must go outside to feed. (1)

..Endangered Species

Flora: Unknown

Fauna: Northern bald eagle (Haliaeetus Levcocephalus alascanus) 
TRANSPORTATION AND UTILITIES

SITE: NEWBERRY CRATER KGRA

..Utility or Energy Transmission Corridors and Facilities

Two Bonneville Power Administration transmission lines are in the vicinity, one to the east and one on the west side of Newberry Crater. A private utility transmission line parallels the BPA line east of the caldera.

Natural gas pipeline parallels Highway 97. (Cascade Natural Gas Co.)

\section{..Transportation Corridors or Facilities}

U.S. Highway 97 connects the Columbia River area to the north with Klamath Falls and California to the south.

U.S. Highway 20 runs east-west between the Bend-Sisters area to the eastern border of the state at Ontario.

Others: State Route 31, Century Drive Scenic Loop (Cascade Lakes Highway), numerous Forest Service and logging roads.

Burlington Northern rail line runs north-south near Highway 97. 
POPULATION

SITE: NEWBERRY CRATER KGRA

..General Description of Population

Newberry Crater is essentially uninhabited except for families operating the two resort facilities. However, the Deschutes County area is one of the fastest growing regions in the state. Between 1960 and 1970 the Deschutes County rural population increased $66 \%$. Much of this growth has taken place in the Bend area between Sisters and LaPine. Developments range from small wooded lots to large planned communities such as Sunriver and Black Butte Ranch. Subdivisions are becoming more common and growth is expected to continue as 15,000 undeveloped lots have been sold. Recreationist and retirees are particularly attracted to the Bend area. (1) (4)

Population Centers:

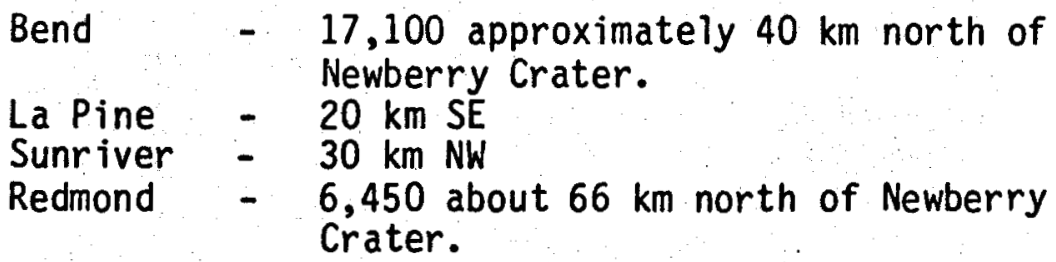

... Economics

..Present Land Use:

Deschutes County has a diversified economy based primarily on timber production, agriculture, livestock raising and recreation. Forest products manufacturing is increasing. Land use at Newberry Crater is focused on extensive recreational use and timber management by the Deschutes National Forest.

..Future Land Use:

No major land use changes in the caldera are anticipated.

Continued growth of residential developments in surrounding areas is apparent. 

SITE: BURNS BUTTE KGRA and BURNS GEOTHERMAL AREA 


\section{BURNS BUTTE KGRA}

Burns Butte is situated about $6 \mathrm{~km}$ southeast of the town of Burns in T.23S., R.30E., Section 28, W.M. The U.S. Geological Survey classified the 640 acre area as a Known Geothermal Resource Area because of overlapping lease applications.

Burns Butte lies in the High Lava Plains province which is characterized by a surface of young and faulted volcanic rocks of moderately high elevation but generally low relief. Cinder cones, calderas and other volcanic surface features such as Burns Butte are evident in parts of the region. Elevations in the immediate vicinity range from $1,500 \mathrm{~m}$. at Burns Butte to $1,267 \mathrm{~m}$. at Burns. Burns butte is within the Harney Basin, an enclosed basin with all streams araining into Harney Lake. The predominate vegetative cover is sagebrush.

The dry climate of the area restricts agricultural production. Much of the land is used for livestock grazing. Ranching is the economic mainstay of the rural population in Harney County. Slightly more than half the Harney County population is concentrated in the Burns-Hines urban area.

In addition to being the population center and the county seat, Burns serves as a trade center for southeastern Oregon. The major industry is wood products and lumber which depends on timber from the nearby Malheur and Ochoco National Forests. Hines, $4 \mathrm{~km}$ southwest of Burns, is a lumber mill town with a population of 1,575 . The sawmill is one of the largest energy consumers in the area (energy use - Appendix B). A portion of the energy needs in the Burns-Hines area could be satisfied by developing local geothermal resources.

A long volcanic history combined with the presence of thermal springs are favorable indications of geothermal potential within the immediate area. These hot springs are located all along the margins of Harney Basin, but ore primarily concentrated in two groups; the largest group is a west northwest belt of springs in the Warm Springs Valley-Harney Lake area, and a second group south of Burns and Hines. The location of the largest group of springs appears to be structurally controlled by the Brothers fault zone. The springs at the southeastern end of the belt have the highest temperature, $68^{\circ} \mathrm{C}$ at the surface. Geothermometers ( $\mathrm{Na}-\mathrm{k}-\mathrm{Ca})$ indicate a minimum estimated reservoir temperature of $132^{\circ} \mathrm{C}$. The group of springs south of Burns is generally low temperature, less than $30^{\circ} \mathrm{C}$, but has substantial flow rates. In adaition to these two main groups, hot springs and warm water wells are scatterea through the area. Much of the water is used for irrigation and water supply for cattle. 
The hottest spring in the basin is Crane Hot Spring situated approximately 16 $\mathrm{km}$ west of the community of Crane. The spring discharges $550 \mathrm{lpm}$ of $80^{\circ} \mathrm{C}$ water. Silica geothermometers indicate a minimum reservoir temperature of $127^{\circ} \mathrm{C}$. This hot spring was once used for a natatorium.

Heat flow and geothermal gradient studies conducted by the Oregon Department of Geology and Mineral Industries in the Harney Basin provide further evidence of the existence of thermal water in the $110-140^{\circ} \mathrm{C}$ range which would be well-suited for direct use applications in the Burns area. Hydrologic studies indicate that flow rates from springs and wells should be substantial. Potential uses include kiln drying of lumber, alfalfa and other grain drying, commercial refrigeration, feed lot operations and methane production, and space heating.

Geothermally heated greenhouses and pavement de-icing would also be attractive considerations given the area's short growing season and severe winters. A district heating system would likely require a large energy consumer, such as the Hines mill, to economically justify service to a small population.

Although no leases have been issued for the Burns Butte KGRA, non-competitive leasing in the Harney Basin has been active. It is estimated that 200,000 acres of private land have been leased for geothermal rights. Most of the leases have been acquired by large energy development companies. Assuming that their interest is in potential geothermal electrical generation, no one is actively pursuing the development of direct use applications for the Burns area. 


\section{SITE DATA SUMMARY}

SITE: BURNS BUTTE KGRA and BURNS GEOTHERMAL AREA

..Physical Reservoir Date

.. Temperature ${ }^{\circ} \mathrm{C}$ -

Temperatures are for an unnamed hot spring near Harney Lake

Surface: $68^{\circ} \mathrm{C}$

Subsurface: $132^{\circ} \mathrm{C}$

..Type of Overlaying Rock: Basaltic tuff and olivine basalt

..Estimated Depth to Top of Reservoir (meters): $1.5 \mathrm{~km}$

.. Site Land Status - KGRA established by overlapping lease applications.

$$
\begin{aligned}
& \text { Total Acres } \\
& \text { Total Acres Leased - } 640 \\
& \text { None in the KGRA }
\end{aligned}
$$

..Geothermal Development Status:

Active exploration in the region.

..Local and State Attitude Toward Geothermal Development:

Geothermal rights have been leased on a large amount of private land.

Public concern on the possible effects of geothermal development on the Malheur National Wildlife Refuge has been expressed.

..Land Use and Population:

The sparse population is concentrated in the Burns-Hines area.

The economy is based on wood products, agriculture, livestock and tourism. 


\section{SITE LOCATION AND PHYSICAL DESCRIPTION}

\section{SITE: BURNS BUTTE KGRA}

.. Latitude: $43^{\circ} 36^{\prime} \mathrm{N}$

..Longitude: $119008^{\prime} \mathrm{W}$

. Rectilinear: Burns Butte KGRA - Section 28, W.M., T.23S., R.30E.

..County: Harney

..Adjacent Counties: Lake, Crook, Grant, Malheur, Humboldt, Nv.

.. Map Reference: AMS Burns, Oregon 1:250,000

.. Topography:

The area lies entirely within the High Lava Plains Province that is characterized by lava flows 1,067 to $1,829 \mathrm{~km}(3,500$ to 6,000 feet) above sea level whose nearly uneroded surface carry few established streams. All of the drainage is into the closed Harney Basin. The nearly treeless, low valley bottoms and plateau areas support mainly sagebrush and bunch grasses, whereas the elevated foothills are covered with scattered juniper.

..Present Land Use:

The primary land uses are agriculture and livestock raising. Portions of the area are managed for wildlife habitat, watershed, open space and recreation.

The KGRA parcel is encumbered by PLO 4858 , a reservation for mainline U.S. Forest Service Road. Presumably it does not forbid mineral leasing. The entire parcel is involved in a pending oil and gas lease application (OR 12551) (14)

The Burns Indian Reservation is east of the town.

U.S. Geological Survey has classified the area as prospectively valuable for oil and gas.

..Future Land Use Plans:

The Harney County Comprehensive Land Use Plan states the following goal: To encourage new industries compatible with the natural resources to develop within the county, consequently located and compatible with their needs and avajlable resource. (14) 
SITE LOCATION AND PHYSICAL DESCRIPTION (continued)

... Aesthetics:

Malheur National Wildlife Refuge is in close proximity.

Diamond Craters has been proposed as a Natural Research area because of its geological, botanical and zoological significance for educational and scientific value.

..Historical/Archaeological Significance:

There are no known historic structures within the lease areas. The Oregon State Inventory of Historic Sites lists two sites bordering the lease areas; Harney Lake Sand Gap (Section 18, T. 27S, R.30E) and the Maiheur National Wildl ife Refuge. None of the proposed lease tracts have been professionally surveyed. The State Historic Preservation Office and University of Oregon files did not reveal any sites located within the lease areas. (14) 
GEOLOGICAL DESCRIPTION

SITE: BURNS BUTTE KGRA

..Geologic Description:

Burns Butte in the Harney Basin lies in the High Lava Plains. The province is an uplifted region of young lava flows. The surface is marked by volcanic features such as cinder cones, craters and lava buttes. Tertiary volcanic rocks are basalt flows, ash-flow tuffs and tuffaceous sediments.

The Brothers fault zone, a major structural lineament, crosses the basin in a northwest-trending direction. Displacement along the faults has localized many of the volcanic surface features. Burns Butte is one of these centers.

The stratigraphy and geologic history of the Harney Basin has been described by Piper, and others (1939):

"Five distinct stratigraphic units span the Miocene and Pliocene epochs. The oldest consists of siliceous extrusions of Miocene (?) age about 1,000 feet thick... The Steens basalt, of Miocene age, rests unconformably on the older siliceous extrusives in the marginal upland along the east half of the basin. Its maximum known thickness, about 2,000 feet, is exposed in the eastward-facing escarpment of Steens Mountain. The component layers average ten feet in thickness; scoriaceous and fragmental zones are common at the top off each layer and afford considerable water-yielding capacity. The Steens basalt is overlain unconformably by the Danforth Formation, of Pliocene age, which crops out extensively over the whole dissected upland and ranges in thickness between 20 feet and 800 feet. In the northwestern part of the basin the upper part of the Danforth Formation comprises stratified siltstone, sandstone, tuff, and volcanic ash with a few intercalated layers of glassy rhylite and one distinctive rhyolite tuff-breccia member. 
The succeeding stratigraphic unit, the Harney

Formation, of Pliocene (?) age, is about 750 feet thick and rests on the Danforth Formation with angular and erosional unconformity. The Harvey Formation underlies an extensive plain of intermediate altitude in the westcentral part of the basin and occurs in outliers along al? margins of the central district except the northern. The formation includes massive basaltic tuff and breccia, sandstone, siltstone, some incoherent gravel, and a few layers of scoriaceous and massive basalt...". (15) (14) 


\section{RESERVOIR CHARACTERISTI'CS}

SITE: BURNS BUTTE KGRA and BURNS GEOTHERMAL AREA

..Reservoir Temperature

..Surface: $68^{\circ} \mathrm{C}$

Hot Springs near Harney Lake

.. Subsurface: $132^{\circ} \mathrm{C}$

..Geochemical

$$
\mathrm{SiO}_{2}: 132^{\circ} \mathrm{C}
$$

Na-K-Ca: $130^{\circ} \mathrm{C}$

..Flow Rates: $550.1 \mathrm{pm}$

..pH: 7.26

..Fluid Chemistry:

Hot Spring

Near Harney Lake

Specific Condutance (micromhos)

Silica

Calcium

Magnesium

Sodium

Potassium

Lithium

Bicarbonate

Carbonate

Sulfate

Chloride

Flouride

Boron

Temperature $\left({ }^{\circ} \mathrm{C}\right)$

$\mathrm{pH}$

Flow (lpm)
2,970

92

12

1.8

630

13

0.45

566

1

140

590

3.3

11.3

68

7.26

550
Crane Hot

Springs
810

83

3.7
0.1
170
3.9
$202^{.09}$
3
86
79
9
7.9
78
8.1
550

0.1

9

7.9

550 (units $\mathrm{mg} / 1$ )

202

$\begin{array}{r}\square 6 \\ \hline\end{array}$

trang

Location: Hot Spring near Harney Lake T.27S., R.29 1/2 E., Section 36; Crane Hot Springs T.24S., R.33E., Section 34, W.M.

..Subsurface Area of Reservoir: $1.5 \mathrm{~km}^{2}$ estimated 
LAND OWNERSHIP AND LEASING

SITE: BURNS BUTTE KGRA

..Land Ownership - TOTAL AREA (KGRA)-640 FEDERAL -640 acres

$\therefore$ Land Leased - FEDERAL (KGRA) - 0

..Number of Sales Offered But No Bids: Two lease sales with no

bids. $6 / 9 / 77$ and $7 / 27 / 78$

.. Number of Bids Rejected (Resulting in No Lease): N/A

.. Summary of Leasing Status and Needs:

A large percentage of land surrounding the Burns Butte KGRA has ben leased on a non-competitive bas is and numerous applications are pending. Potential developers are obviously interested in the area. Nevertheless, no bids have been received on the 640 acres of KGRA land in two lease sales. Burns Butte should be declassified a KGRA so the land can be leased non-competitively. 


\section{GEOTHERMAL DEVELOPMENT STATUS}

\section{SITE: BURNS BUTTE KGRA}

..Present Development Status:

Hot springs in the area are used for irrigation and stock watering.

Geothermal exploration in the vicinity has been mildly active.

..Projected or planned Development:

Further exploration drilling is expected. 
INSTITUTIONAL CONSIDERATIONS

SITE: BURNS BUTTE KGRA

\section{..Institutional Requirements:}

Exploration and development activities may require conditional use permits from Harney County.

Much of the area has been zoned agricultural. The planning and zoning ordinance describes this classification as "extended to preserve certain land exclusively for agricultural and related uses which land while so used is exempt from zoning and land use regulations." The ordinance also states that it will prevent intensive development in areas where proper community services are not readily available and where certain activities would be in conflict with an orderly development of suburban areas, or where agricultural and related operations constitute the most appropriate use of the land.

Geothermal operations are listed as one of the conditional uses under this ordinance. The county planning commission regulates conditional uses on a case-by-case basis.

-. Agency and Public Attidues:

Public response to the Environmental Analys is Report expressed concern about the proximity of the area to the Malheur National Wildlife Refuge, and supported nomination of Diamond Craters as a Natural Resource Area.

Over 200,000 acres in the Harrey Bas in have been leased by private landowners. It is assumed that this interest has financial motivation.

As part of the U.S. Forest Service Roadless Area Review and Evaluation process, 30,000 acres at Harney Lake are being considered for possible inclusion in the National Wilderness preservation System. The area is managed by the U.S. Fish and Wildlife Service. (12)

..Status of Requirements (i.e., EIA/EIS Requirements):

EAR for Burns District Non-competitive Geothermal Area and Burns Butte KGRA completed 2/77. 


\section{ENVIRONMENTAL FACTORS}

SITE: BURNS BUTTE KGRA

..CLIMATE

..Prevailing Winds: Westerly

..Precipitation (Annual): $32.62 \mathrm{~cm}$ (12.82 inches)

. Average Temperature $7^{\circ} \mathrm{C}\left(44^{\circ} \mathrm{F}\right)$

Minimum: $-1.3^{\circ} \mathrm{C}\left(29.7^{\circ} \mathrm{F}\right)$

Maximum: $20.6^{\circ} \mathrm{C}\left(69.5^{\circ} \mathrm{F}\right)$

..Degree Days (annua1): 7,212

..AIR QUALITY:

Air quality is good over much of the region. The major sources of particulate matter originate from the Hines mill and transportation vehicles, occasional dust storms deposit large amounts of particulates in the air for short periods of time. Carbon monoxide, hydrocarbon, nitrogen oxide, and sulphur oxide concentrations are all extremely low. (14)

..WATER QUALITY:

Most of the runoff in the area occurs in winter and early spring and varies from 2.5 to $5.0 \mathrm{~mm}$ ( 1 to 2 inches). Warm spring chinook winds cause rapid snow melt and consequently heavy runoff.

Typical of eastern Oregon, the evaporation rate is high with pan evaporation varying from $102 \mathrm{~mm}$ ( 40 inches) in the forested areas to $152 \mathrm{~mm}(60+$ inches $)$ in the lower open valleys.

Many of the smaller streams have little or no flow except during periods of melting snow and high runoff, Water temperatures for many of these streams are commonly $21^{\circ} \mathrm{C}\left(70^{\circ} \mathrm{F}\right)$ or higher in late summer and near freezing from November to Apri1. They are generally well aerated with dissolved oxygen concentrations near saturation levels, averaging 8 to $12 \mathrm{mg} / 1$.

Water quality of the perennial streams is good to excellent but decreases substantially in the downstream portions because of increases in mineral content. The amounts of calcium and sodium vary; calcium is usually predominant during high flow periods. 
Several reservoirs are located in the geothermal area, most of which are less than 3 acre-feet. Their primary purpose is to provide water for livestock, but they also provide water for wildlife and habitat to the aquatic plants and amphibians. The availability of water in these reservoirs is adequate in most years. Projected needs for municipal, industrial, domestic and livestock water will double by the year 2020. Ground water supplies are estimated to be adequate to meet the demand.

A11 of the streams flow into the Harney Bas in which has no outflow. The Harney Basin watershed provides important habitat for waterfowl. The Malheur Lake levels fluctuate greatly from year to year. (14)

.. NOISE: Low Levels.

. BIOLOGICAL *

..Dominant Flora:

Major vegetation types are of the following assocations:

$\begin{array}{ll}\text { Low sagebrush } & (\text { Artemisia arbuscula) } \\ \text { Big sagebrush } & \text { (Artemisia tridentata) } \\ \text { Western Juniper } & \text { (Uniperus occidentalis }\end{array}$

..Dominant Fauna:

Mule deer, elk, antelope, sage grouse, eagles, chukars, lizards, coyotes, raptorial birds, wild horses.

The Harney Basin, particularly the Malheur Wildlife Refuge, provides important habitat for a wide variety of migratory waterfowl numbering in the thousands.

..Endangered Species

Flora: None Known.

Fauna: Northern blad eagle (Haliaeetus leucocephalus)

Sage grouse strutting grounds have been documented in T.29S, R.30E. Sec. 14 and 23, and others probably exist. (14)

Golden eagles nest in the area, particularly along the rim south of Harney Lake and the rim west of Highway 205. Two nests in T.29S, R.31E., Sec. 22 often are active. Golden eagle nests also documented to the west of Diamond Craters, on the Malheur Refuge, and within the craters. (14)

*The seasonal and geographical distribution of water supplies strongly influences the numbers and distribution of floral and faunal species. 


\section{TRANSPORTATION AND UTILITIES}

SITE: BURNS BUTTE KGRA

..Utility or Energy Transmission Corridors and Facilities

Bonneville Power Administration maintains the Redmond-Hampton-Harney $115 \mathrm{KV}$ line.

The Harney Electrical Cooperative provides service to the area.

..Transportation Corridors or Facilities

Roads:

Highway 20

Highway 395

State Route 78

State Route 205

Secondary roads

Railroads:

Union Pacific line to Ontario

Oregon and Northwestern 
POPULATION

SITE: BURNS BUTTE KGRA

..General Description of Population

Harney County has the lowest population density $(0.7$ persons per square mile) in the state. More than half of the county population $(7,500)$ is concentrated in the Burns-Hines area. The Burns Indian Reservation is situated west of town.

Population (1978 estimates):

Burns - 3,525

Hines - 1,575- $4 \mathrm{~km}$. S.W. of Burns

Crane - small community $43 \mathrm{~km}$. S.E. of Burns

.. Economics

Present Land Use:

Burns is the trade center for southeastern Oregon. The major industries are lumber, livestock, agriculture and tourism. Wood products and lumbering are by far the largest. Timber comes from the Ochoco and Malheur National Forests. Hines is a lumber mill town. The rural population is based primarily on ranching. 
High Lava Plains Region References

(1) Deschutes National Forest, 1975, Environmental Analysis Report for Geothermal, Leasing in the Ft. Rock Ranger District.

(2) U.S. Geological Survey, Geothermal Resources File (Geotherm) Revision 8, Computer Data File.

(3) Waring, Gerald, A., 1965, Thermal Springs of the United States and Other Countries of the World - A Summary: U.S. Geological Survey Professional Paper 492.

(4) Peterson, N. V., Groh, E. A., Taylor, E. M., Stensland, D. E., 1976, Geology and Mineral Resources of Deschutes County, Oregon: Oregon Department of Geology and Mineral Industries Bulletin 89.

(5) Hul1, D. A., Blackwe11, D. D., Bowen, R. G., Peterson, N. V., and Black, G. L., 1977, Geothermal Gradient Data: Oregon Department of Geology and Mineral Industries, Open File Report 0-77-2.

(6) Vaughan, E., Deschutes National Forest, Personal Communication, October, 1978.

(7) Higgins, Michael W., and Waters, Aaron, C., 1967, Newberry Caldera, Oregon: A Preliminary Report: Ore Bin, V. 29, N. 3 .

(8) MacLeod, N. S., Walker, G. W., and McKee, E. H., 1975, Geothermal Significance of Eastward Increase in Age of Upper Cenozoic Rhyolitic Domes in Southeastern Oregon: U.S. Geological Survey Open File Report 75-348.

(9) Peterson, N. V., and Groh, E. A., 1965, Newberry Volcano Area Field Trip, Lunar Geological Field Conference Guidebook: Oregon Department of Geology and Mineral Industries Bulletin 57.

(10) Peterson, N. V., and Groh, E. A., 1969, The Ages of Some Holocene Volcanic Eruptions in the Newberry Volcano Area, Oregon: Ore-Bin, V. 31, N. 4. 
(11) Hu11, D. A., Blackwe11, D. D., Bowen, R. G., and Peterson, N. V., 1977, Heat Flow Study of the Brothers Fault Zone, Oregon: Oregon Department of Geology and Mineral. Industries, Open File Report 0-77-3.

(12) U.S. Forest Service, 1978, Oregon State Supplement to the Draft Environmental Impact Statement Roadless Area Review and Evaluation II.

(13) Mariner, R. H., Rapp, J. B., Willey, L. M. and Presser, T. S., 1974, The Chemical Composition and Estimated Minimum Thermal Reservoir Temperatures of Selected Hot Springs in Oregon: U.S. Geological Survey, Open File Report.

(14) Bureau of Land Management, 1977, Environmental Analys is Report for Proposed Geothermal Leasing for Burns District Non-competitive Geothermal Applications and Burns Butte KGRA: Burns District.

(15) Piper, A. M., Robinson, T. W., and Park, C. F., Jr., 1939, Geology and Groundwater Resources of the Harney Basin, Oregon: U.S. Geological Survey Water Supply Paper 841 . 
The Brothers fault zone is a major structural lineament crossing central Oregon from Steens Mountain through Brothers and possibly extending to the Cascade Range. It forms the northern boundary of the Basin and Range physiographic province in Oregon. Stewart and others (1975) suggest that the zone may be the northwesterly portion of the Oregon-Nevada lineament which extends from north-central Nevada to the Oregon Cascades near Mt. Jefferson.

The Brothers fault zone has been described by Peterson and others (1976) as a northwest-trending belt of closely spaced en echelon normal foults. The belt extends about $300 \mathrm{~km}$ trending in a general N $60^{\circ} \mathrm{W}$ direction across the High Lava Plains region: Walker (1969) suggests that "normal faults of the zone and the many volcanic vents along the zone represent only the surface manifestations of deformation on a large, deeply buried structure, the exact nature of which is not known. The pattern of normal faults within and near the Brothers fault zone and the relation of many small monoclinal folds to the faults suggest, however, that the zone overlies a deeply buried fault with lateral displacement; the normal faults denote only adjustment of surface and near-surface volcanic and tuffaceous sedimentary rocks."

Normal faults of the zone are generally $20-30 \mathrm{~km}$ long with minor horsts and grabens developed between them. Individual faults along the zone have aisplaced all the rocks in the area except the latest Pleistocene "Badlands lava" (Peterson 1976).

As described by Hull and others (1977), "the zone traverses an interlayered sequence of volcanic and sedimentary rocks ranging in age from Miocene to Holocene. The volcanic rocks at the surface are predominately basalt flows and rhyolitic ash-flow tuffs with scattered rhyolite and rhyodacite domes. The sedimentary rocks are poorly indurated tuffaceous sandstone, siltstone and claystone of fluviatile and lacustrine origin".

Walker (1974) and MacLeod and others (1975) have noted a general progressive decrease in age of silicic volcanic vents from east to west along the Brothers fault zone. Age dating of volcanic rocks suggests that movements along the zone have migrated similarly to the northwest. Duck Butte in the eastern part of Harney Basin has an estimated age of about 10 million years. Further west along the zone, Glass Buttes has an age of about 5 million years. Newberry Crater, still farther west, contains silicic rocks dated about 1,300 years (Peterson and Groh 1969). Pine Mountain and Iron Mountain are exceptions to the pattern of progressively younger silicic rocks from east to west (Hull and others, 1977). 
In reporting on the geothermal potential in southeastern Oregon, MacLeod and others (1975) state: "Most electric power-producing geothermal fields in the world occur in or proximal to areas of young silicic volcanic rocks. On the basis of the well-defined age progession of rhyolitic domes in Southeastern Oregon, silicic bodies sufficiently young to be heat sources for geothermal systems are likely only in the vicinity of Newberry Volcano at the west end of the northern belt of domes."

A considerable amount of geophysical data provides further indications of geothermal resource potential in the vicinity of the Brothers fault zone. Of particular note is the Heat Flow Study of the Brothers Fault Zone conducted by the Oregon Department of Geology and Mineral Industries.

During 1975 and 197638 holes were drilled and 15 water wells were measured for geothermal gradients and estimated heat flow values. As a result of the study three areas along and near the Brothers fault zone were identified as being especially promising for geothermal resource development: Harney Basin, Glass Buttes and Newberry Volcano.

Newberry was designated as having high potential based primarily on geologic considerations. Heat flow measurements in the area were not reliable because of shallow well depth and the influence of groundwater migration. But the study did suggest that heat flow values in basalt in the Newberry vicinity be measured in holes at least 300 meters deep to overcome the effects of regional groundwater movement.

At Glass Buttes a broad area of anomalous heat flow with values at least 50 percent above the regional average was outlined. Two holes on the north and south flanks of Glass Buttes had gradients of $144^{\circ}$ and $120^{\circ} \mathrm{C} / \mathrm{km}$ and heat flow values of 3.1 and $2.9 \mathrm{HFU}$. Extensive hydrothermal alteration and low apparent electrical resistivity provide further evidence of geothermal potential.

In the Harney Basin, anomalously high heat flow values were identified in three areas: Coyote Buttes, Crane Hot Springs and Diamond Craters. Gradient data for Coyote Buttes show a high range of about $73^{\circ}$ to $160^{\circ} \mathrm{C} / \mathrm{km}$ and average heat flow values of 3.0 HFU.

Numerous hot springs and wells in the Harney Basin further support the presence of a thermal anomaly. Silica geothermometry techniques applied to many of the hot springs result in estimated reservoir temperatures in the range of $110-140^{\circ} \mathrm{C}$. Temperatures in this range are well suited for non-electric geothermal applications. 
According to the study, the distribution of hot springs and wells suggests that the areas of high heat flow may be larger than is now known. Particularly noted are the group of hot springs which extend $30 \mathrm{~km}$ to the west from Coyote Buttes and the numerous warm wells near Burns and Hines on the northern side of the basin. It has been suggested that the area of high heat flow may extend from Coyote Buttes northwesterly to Glass Buttes.

The geothermal potential of areas surrounding the Brothers fault zone is of high interest to private companies. As summarized in the following table large tracts of land have been leased on a non-competitive basis. In addition numerous lease applications are pending with the Bureau of Land Management.

In summary, the Brothers fault zone appears to have excellent potential for geothermal resource development. It is assumed the large energy companies that have acquired leases are interested in the possibility of electrical generation. Nevertheless, information now available to the public does not substantiate a resource capable of power generation. For this reason, it is unrealistic to make scenario projections for electric power-on-line. Further exploration is needed to confirm and define the extent of the resource. Non-electric geothermal applications, on the other hand, are likely, to develop in the Burns area. 
Non-Competitive Geothermal Leases

\begin{tabular}{lcc} 
Leasee & Area & Total Acreage \\
\hline Phillips Petroleum Co. & Glass Buttes & 23,492 \\
California Geothermal & Glass Buttes & 26,764 \\
Francana Resource & Glass Buttes & 1,596 \\
Leonard Lundgren & Glass Buttes & 640 \\
Energy Partners & Burns Butte & 4,668 \\
& & \\
Estimated leasing of private land in the Harney Basin - 200,000 acres.
\end{tabular}




\section{Brothers Fault Zone References}

Bowen, R. G., Blackwell, D. D., Hull, D. A., 1977, Geothermal Exploration Studies in Oregon: Oregon Department of Geology and Mineral Industries Miscellaneous Paper 19.

Hull, D. A., 1976, Electrical Resistivity Survey and Evaluation of the Glass Buttes Geothermal Anomaly: Oregon Department of Geology and Mineral Industries Open File Report 0-76-11.

Hull, D. A., Blackwell, D. D., Bowen, R. G. and Peterson, N. V., 1977, Heat Flow Study of the Brothers Fault Zone, Oregon: Oregon Department of Geology and Mineral Industries Open File Report 0-77-3.

Hull, D. A., Bowen, R. G., Blackwell, D. D., Peterson, N. V., 1975, Geothermal Gradient Data Brothers Fault Zone, Oregon: Oregon Department of Geology and Mineral Industries Open File Report 0-76-2.

NiacLeod, N. S., Walker, G. W. and McKee, E. H., 1975, Geothermal Significance of Eastward Increase in Age of Upper Cenozoic Rhyolitic Domes in Southeast Oregon: U.S. Geological Survey, Open File Report.

Peterson, N. V. and Groh, E. A., 1969, The Ages of Some Holocene Volcanic Eruptions in the Newberry Volcano Area, Oregon: Ore Bin, V. 3I, N. 4.

Peterson, N. V., Groh, E. A., Taylor, E. M. and Stensland, D. E., 1976, Geology and Mineral Resources of Deschutes County, Oregon: Oregon Department of Geology and Mineral Industries Bulletin 89.

Stewart, J. H., Walker, George W., and Kleinhampl, F...J., 1975, Oregon-Nevada Lineament: Geology, V. 3, N. 5.

Walker, George W., 1969, Geology of the High Lava Plains Province, Mineral and Water Resources of Oregon: Oregon Department of Geology and Mineral Industries Bulletin 64.

Walker, George W., 1974, Some Implications of Late Cenozoic Volcanism to Geothermal Potential in the High Lava Plains of South-Central Oregon: Ore Bin, V. 36, N. 7 . 


\section{WESTERN SNAKE RIVER PLAIN GEOTHERMAL PLANNING REGION}

Covering three geomorphic zones, the planning region is part of the vast Snake River structural basin. The topography is similiar to the Basin and Range region except that the plateaus are generally older and more dissected, and contain more sedimentary rocks. Major drainages include the Malheur, Owyhee and Snake Rivers.

Population concentrations are centered around Vale, Ontario and Nyssa in east central Oregon adjacent to the Idaho border. These towns are surrounded by rich agricultural land, which supplies the major base of the area's economy. Potatoes, sugar beets and onions are grown and processed in the area for regional and national distribution. Although appearing to be somewhat isolated from the major population centers in Oregon, the area has ready access to regional transportation networks.

The potential for commercialization of geothermal resources is high, particularly for non-electrical applications. Primary targets are the food processing industry and district heating systems. The possibility of thermal fluids of adequate temperature for generation of electricity is not known.

The U.S. Geological Survey has classified the area around and southeast of the town of Vale as a KGRA. The following chapter presents specific data on the Vale KGRA and a discussion of the regional potential for geothermal energy development. 


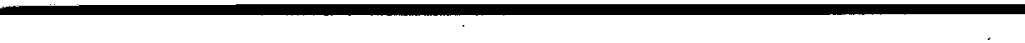


SITE: VALE KaRA, OREGON

191 

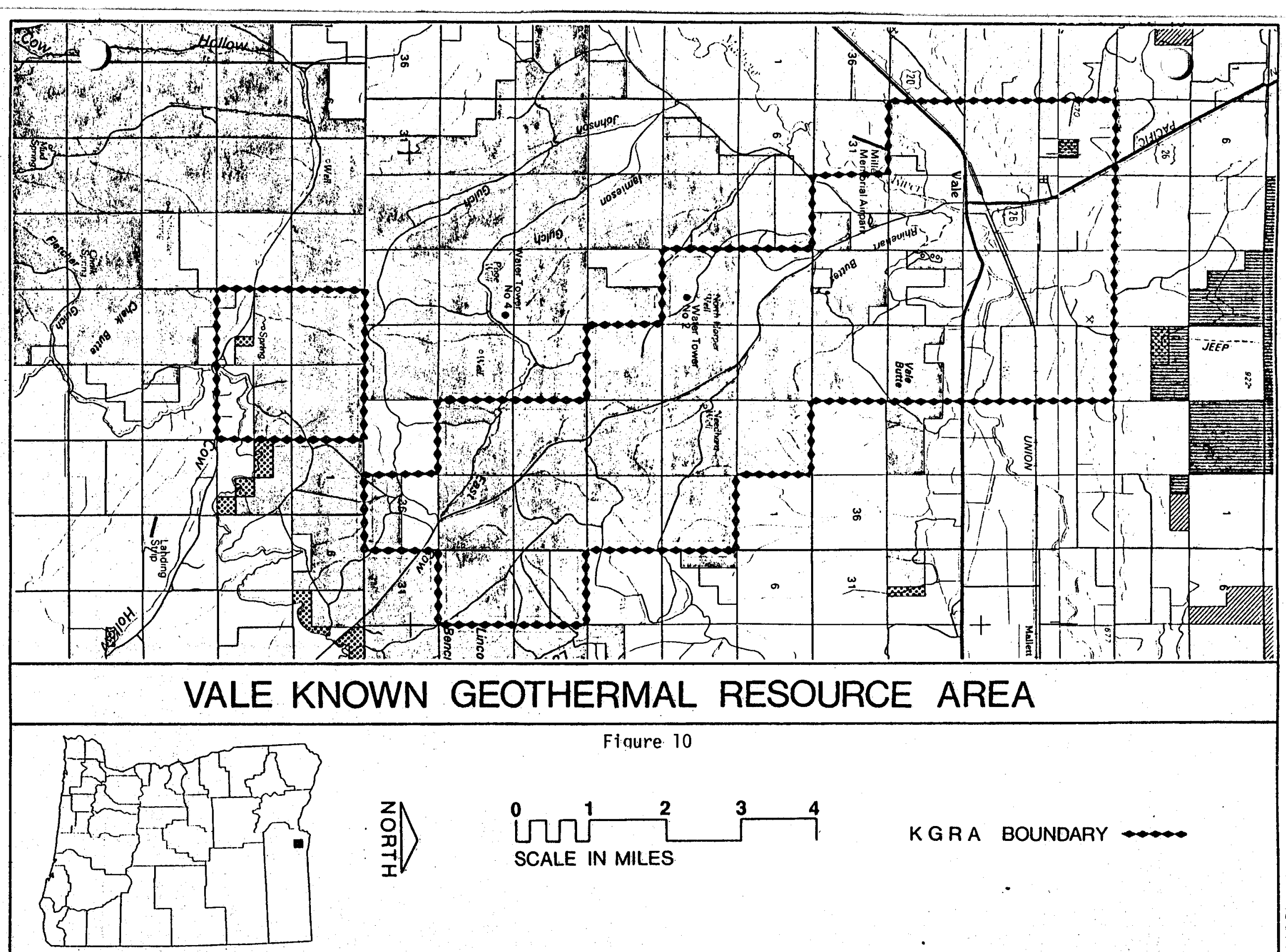

$z$
0
0
-1
1

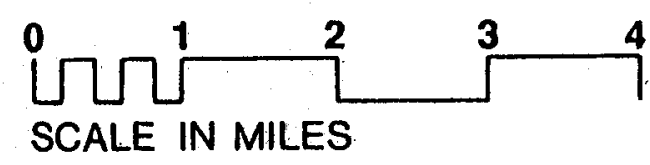

KGRA BOUNDARY 


\section{VALE KGRA}

Vale is situated in east central Oregon near the Idaho border. The town is situated in T.18S., R.45E., Willamette Meridian. The broad area covers three geomorphic zones: Blue Mountains, High Lava Plains and Owyhee Upland. The location of the area is in the western Snake River Basin which is part of a large trough extending from Wyoming across Idaho and into eastern Oregon. Overall, the topography is characterized by a series of linear valleys and mountains which have been more highly dissected than the same structural features in the Basin and Range province.

The KGRA covers 22,998 acres of publicly and privately-owned land southeast of Vale and surrounding the town itself. Originally the U.S.G.S. designated 8,940 acres for competitive bidding purposes in 1974. Subsequent geologic studies and overlapping non-competitive lease applications prompted the addition of 14,058 acres to the Vale KGKA.

Approximately 75 percent of the Malheur County population, 24,600 in 1976, lives within a $40 \mathrm{~km}$ radius of the Vale KGRA. The county as a whole is undergoing a shift from rural to urban. The principal towns and their estimated 1978 populations are: Vale $(1,900)$, Nyssa $(3,000)$, and Ontario $(8,950)$.

The physical environment and geographical location of the area has led to the development of an agricultural based economy which produces high yield crops on irrigated land. Crops include sugar beets, onions, potatoes, corn, and alfalfa. The area also has a dairy products industry.

Food processing operations have developed around these crops and is the only major industrial activity in the area. Currently, the major food processing crops are potatoes and sugar beets, but an onion processing operation planned in Nyssa will elevate onions from a minor to major status as a processed product. Most of the plants have used natural gas to supply process heat in the past. Because of increased costs and questions of availability, many of the plants are converting to oil or coal and one is retrofitting to geothermal energy.

The potential for additional agri-industrial and other direct use applications of geothermal energy is excellent. Although thermal waters have not been used in the area, except for a few shallow wells near Vale Hot Springs, the surface manifestations of hot springs and knowledge of subsurface geology acquired from deep oil and gas exploration drilling, indicate that the necessary conditions for direct geothermal use are present. 
The U.S.G.S. has estimated that Vale Hot Springs has both a very large subsurface area and large heat content. Klamath Falls is the only area in Oregon with higher reservoir potential estimates. Surface temperature at Vale Hot Springs has been measured at $73^{\circ} \mathrm{C}$. Geothermometry indicates minimum reservoir temperatures of $153^{\circ} \mathrm{C}\left(\mathrm{SiO}_{2}\right)$ and $158^{\circ} \mathrm{C}(\mathrm{N}-\mathrm{K}-\mathrm{Ca})$.

Additional subsurface temperatures based on projections of near-surface gradients have been estimated by Bowen and Blackwell (1975), Hull (1975) and reported by Lienau and others (1978). The estimates were made using a regional average gradient of $85^{\circ} \mathrm{C} / \mathrm{km}$ projected to depths where basaltic reservoir rocks are expected to occur. If the depth to the Grassy Mountain Basalt is $1 \mathrm{~km}$, assumed temperatures would be in the range of $90^{\circ}$ to $100^{\circ} \mathrm{C}$. If drilling encountered Owyhee Basalt of $2 \mathrm{~km}$, the expected temperatures range from $140^{\circ}$ to $165^{\circ} \mathrm{C}$.

According to Lienau and others (1978), if the anticipated utilization of geothermal fluids within these temperature ranges can justify deep drilling, there is reasonable assurance that the resource can be found anywhere in the Western Snake River Plain. Additional information on the potential geothermal resource environment is presented in the Vale KGRA data sheet.

Results of geologic and geophysical investigations indicate that the Vale KGRA and surrounding area is one of the best geothermal prospect areas in Oregon. Possible developers have recognized this potential as reflected in the abundant leasing and exploration activities in the area. It is assumed that the large energy companies are interested in the Vale area for geothermal electrical generation. However, available data do not justify an electrical power potential evaluation in the scope of this report.

Based on existing data, geothermal resources in the Vale area are best suited for direct use applications. The indicated high temperatures and large reservoir volume opens the door to a wide range of possible applications.

Considering the economy of the region, the most logical user is the food processing industry. Processing consumes large amounts of energy in the $60^{\circ}$ to $148^{\circ} \mathrm{C}$ range. Geothermal fluids could readily supply a major portion of these thermal requirements at a cost comparable to or less than conventional fuels.

Lienau and others (1978) examined the resource potential and compiled preliminary designs and cost benefit analyses of retrofitting to geothermal systems for two existing food processors in the western Snake River Plain. The Amalgamated Sugar Company, in Nyssa, is the only beet sugar refinery in Oregon. The plant burns coal to produce steam for processing. Cost analyses are favorable for converting to geothermal resources to provide the large amount of energy used in the evaporation process. 
The second processor examined was Ore-Ida Foods, Inc. Situated on the Oregon-ldaho border in Ontario, Ore-Ida processes more than two million pounds of potatoes per day into frozen potato products. An evaluation and initial design indicate that geothermal fluids could provide 55 percent of the process energy requirements and result in a net annual saving of about $\$ 1,000,000$ in the first year of operation.

These results were attractive enough to stimulate Ore-lda to seek partial federal funding for a project to demonstrate the feasibility of using geothermal fluids for food processing. Contract negotiations have been completed and preliminary surface examinations have begun. Drilling should begin by mid 1979. The system is scheduled to be operational by in early 1980. Encouraged by the opportunity to replace the company's use of conventional fuels, Ore-lda is examining the feasibility of using solar energy to meet the 45 percent of their process heat requirements which available thermal fluids cannot supply.

Geothermal development is also underway in Vale. A private company has designed and is building a five acre mushroom growing facility. The operation is adjacent to the present florist's greenhouses which use thermal water from the Vale Hot Springs area. Geothermal energy will be used for space and process heating, and possibly in Oregon's first application of geothermal cooling. It is anticipated that the focility will be in operation in 1979.

These projects will only begin to tap the geothermal resource potential in the Vale area. Other food processors could realize significant savings in fossil fuel costs by converting to geothermal energy. New plants coming into the area, such as the onion processing facility in Nyssa, could design systems initially to use thermal fluids and accrue the benefits of using a local energy resource.

Commercial greenhouses could be established to supplement the area's economy. Greenhouse crops could extend the season for farmers and food processors alike. Crops such as tomatoes, tree seedlings, bedding plants, flowers and others could be added to the present agricultural production.

One of the most efficient ways of utilizing geothermal resources would be to site several of these end-users in an industrial park using a cascaded system. Higher temperature energy uses such as cold storage facilities and food processors would be on the near end of the geothermal system with lower temperature applications such as greenhouses and aquaculture ponds at the farthest end. Such a system would conserve use of the resource, be less costly since fewer wells would be needed than for individual applications, and minimize disposal problems. Economics would prevent the relocation 
of existing plants into this type of system, but it is a viable option for new businesses in the area or for present operations to expand their scope of operation. Each of the discussed applications have energy requirements which suitably could be met by geothermal fluids available in the area.

In addition to these agribusiness applications there is considerable potential for geothermal space and hot water heating in the Vale, Ontario and Nyssa areas. The establishment of district heating systems is the best approach to insure systematic and efficient resource development.

The town of Vale, which is the Malheur County seat, has actively been pursuing the creation of such a system for several years. The layout of the town is ideal for an initial demonstration project to supply heating for several public buildings. The county courthouse, city hall, county jail, public swimming pool, high school, grade school and public library are all concentrated in a central area. Several blocks away the county owns a parcel of land along the Malheur River just upstream from Vale Hot Springs. While thermal waters bubble to surface a public pool three blocks away is heated with propane.

To rectify this situation county and other local officials are anxious to take advantage of their available local energy resource. The County submitted a Local Public Works Capital Development and Investment Program Application to the Economic Development Administration of the U.S. Department of Commerce in 1976 for funding of the district heating system for the public buildings. Funding was denied. Unless outside funding can be obtained the city is likely to continue heating the public pool with comparatively expensive propane. Reportedly the existing tax base of the area cannot justify construction of the system despite the fact that it would result in considerable savings over the cost of using conventional fuels.

In general, geothermal development in the Vale area is likely in the near term with high probability of success. Local attitudes are in strong support of utilizing indigenous resources. Not only will it reduce dependence on fossil fuels but it will enhance the area's economy.

Two particular examples of local anticipation of geothermal development are; a BLM building under construction in Vale has a heating system designed to be easily converted for geothermal use, and the formulation of Oregon's first county ordinance to encourage and plan for coordinated geothermal development by Malheur County in 1974 (included in Appendix F). The area needs economic stimulation to spark geothermal resource utilization. 
SITE DATA SUMMARY

SITE: VALE KGRA

..Physical Reservoir Data

.. Temperature ${ }^{\circ} \mathrm{C}$

Surface: $7^{\circ} \mathrm{C} \quad$ Subsurface: $160^{\circ} \mathrm{C}$

(1)

..Type of Overlaying Rock: Loosely consolidated sandstone, siltstone, some fresh limestone occasionally inter-bedded with basalt flows

..Estimated Depth to Top of Reservoir (meters): 1,000 m.

.. Site Land Status

Total KGRA Acres - 22,998

Total Acres Leased

$\frac{\text { FED. }}{14,565 \text { (approx) }} \frac{\text { STATE }}{13,921} \frac{\text { PRIVATE }}{1,280} \frac{\begin{array}{c}8,433 \text { (approx.) } \\ \text { Unknown }\end{array}}{\text { Un }}$

..Geothermal Development Status:

Three geothermal greenhouses produce plants for a florist in Vale.

..Local and State Attitude Toward Geothermal Development:

Generally supportive of geothermal development.

..Land Use and Population:

The area is basically rural in nature despite the fact that $75 \%$ of the Malheur County population lives with a $40 \mathrm{~km}$ radius of the KGRA.

Agricultural and livestock production are the primary land uses. Food processing is an important factor in the area's economy.

In general, the valleys and low foothills in the area are privately-owned with the uplands in federal ownership. Public lands are managed by the Vale District office of the BLM. 
SITE LOCATION AND PHYSICAL DESCR IPTION

SITE: VALE KGRA

.. Latitude: $430591 \mathrm{~N}$

... Longitude: $117014^{\prime} \mathrm{W}$

..Rectilinear:

Secs. 15-22, 27-30, 32, 33, 34, T.18S., R.45E. W.M.

Secs. $2-4,9-15,23-26,36, T .19 S .$, R.45E.

Secs. 19, 30, T.19S., R.46E.

... County: Malheur

..Adjacent Counties: Harney, Baker, Or.; Washington, Payette, Canyon, Owyhee, Idaho; Humboldt, Nv.

..Map Reference: USGS Vale East $1: 24,000$, Vale West $1: 24,000$ AMS Boise 1:250,000

.. Topography

The area is characterized by rolling plateaus dissected by several intermittent drainages. Malheur River and adjacent flood plain separate two of the plateau areas. Elevations range from $683 \mathrm{~m}$. at Vale to $975 \mathrm{~m}$. on hills in the area. Slopes vary from nearly level to steeply sloping. The land around the KGRA covers three geomorphic zones: Blue Mountains, High Lava Plains and the Owyhee IJpland. Elevations range from about $609 \mathrm{~m}$. near the Snake River to mountainous plateus averaging $1,524 \mathrm{~m}$. and isolated peaks above $1,829 \mathrm{~m}$. along the western margin. The major drainages include the Malheur, Owyhee and Snake Rivers.

..Present Land Use:

The majority of land in the area is used for agricultural production, livestock grazing and urban centers. Recreation is a secondary land use.

Exploration for oil and gas has taken place in the Vale area sporadically since the early 1900s.

Approximately 1060 acres within the KGRA have been set aside as grazing allotments. 
..Histroical/Archaeological Significance:

Approximately $14 \mathrm{~km}$ of the historic Oregon Trail parallels present day Lytle Boulevard which passes through the KGRA. The trail qualifies for inclusion in the National Register of Historic Places.

Vale Hot Springs was a well known stop for early travelers over the historic Oregon Trail.

(4) 


\section{GEOLOGICAL/GEOPHYSICAL DESCRIPTION}

\section{SITE: VALE KGRA}

\section{..Geologic Description:}

Geology of the Vale area has been summarized from Corcoran and others (1962), and Bowen and Blackwell (1975).

The oldest exposed unit in the Vale area is the Sucker Creek Formation consisting primarily of volcanic tuffs and tuffaceous lacustrine deposits with interbedded acidic flows and intrusives.

Overlying the Sucker Creek Formation is the Owyhee Basalt of mid-Miocene age. It is an extensive section of basalt flows and interbedded tuff approximately $396 \mathrm{~m}$. (1,300 ft.) thick.

Above the Owyhee Basalt is the Deer Butte Formation of late Miocene age. The section is composed of fine-grained tuffaceous stiltstone and shale with interbedded basalt flows in the lower portion grading upward into massive sandstone and conglomerate. Thickness ranges from $122 \mathrm{~m}$. ( $400 \mathrm{ft}$.) to a maximum of $380 \mathrm{~m}$. $(1,248 \mathrm{ft}$.$) . The Deer Butte Formation is exposed at Vale Butte$ where the well-cemented conglomerate and sandstone have formed an erosional remnant.

Overlying the Deer Butte Formation with apparent unconformity is the Kern Basin Formation composed of tuffaceous claystone, siltstone, sandstone and less commonly conglomerate. Kern Basin Formation is the lowest section of the Idaho Group of Pliocene age. The group was divided by Corcoran and others (1962) into three sections: two lacustrine units, Chalk Butte and Kern Basin Formations, separated by the Grassy Mountain Basalt. The Kern Basin Formation is not exposed throughout the area.

Corcoran and others (1962) report thickness of the Grassy Mountain Basalt to be $152 \mathrm{~m}$. (500 ft.) to $305 \mathrm{~m}$. (1,000 ft.) thick. It underlies the Chalk Butte Formation which is the most abundant rock type at the surface. Chalk Butte is composed of tuffaceous claystone and siltstone with lesser amounts of tuff conglomerate, ash beds, fresh-water limestone and minor interbedded basalt flows. Thickness of the formation ranges from $762 \mathrm{~m} .(2,500 \mathrm{ft}$.$) to 1067 \mathrm{~m} .(3,500 \mathrm{ft}$.$) (Bowen and$ Blackwell, 1975).

These Tertiary units are covered by Quaternary alluvium and terrace gravels in the valleys of Snake and Malheur Rivers and Willow Creek. 
The dominant structural feature of the area is the Western Snake River basin which is part of the Snake River downwarp. This large structural trough, occupied by the Snake River, extends from Yellowstone Park in Wyoming across southern Idaho and into eastern Oregon. High-angle faults which bound the large graben in Idaho have not been identified in Oregon.

Bowen and Blackwell (1975) have indicated three fault zones in the area. The Willow Creek fault has been identified as a major northwest-trending fault zone based on physiographic expression and geophysical measurements. The fault is evidenced by the jineament formed by Willow Creek valley which extends for $48 \mathrm{~km}$ in a nearly straight line to the northwest of Vale.

Vale Hot Springs is situated on the fault which also traverses the Cow Hollow geothermal anomaly. Willow Creek fault is included in the series of right lateral fault zones described as the Vale Zone by Lawrence (1976).

The Bully Creek fault parallels the Willow Creek fault about 10 $\mathrm{km}$ to the west. Uplifting of Owyhee Basalt on the west side of the Bully Creek zone indicates that the area between the Bully Creek and Willow Creek faults is a graben.

The third fault known as the Malheur River fault runs northeast of Vale roughly paralleling the Malheur River. It is approximately perpendicular to the Willow Creek fault and Vale Hot Springs is located at the intersection of the two zones. (7) (8)

- Geophysical Summary:

Geologic mapping of Mitchell Butte Quadrangle was completed by Corcoran and others (1962). (7)

Newton and Corcoran (1963) compiled a reconnaissance map of the Western Snake River Basin and correlated the subsurface geology of the region based on drilling information from deep $0 i\}$ and gas exploration wells. (12)

An audiomagnetotelluric survey was carried out in the Vale-Weiser, Idaho area by Long and others (1976). The study delineated five areas of anomalous low apparent resistivity; three in Oregon and two in Idaho. The Oregon anomalies are near vale close to hot springs or areas of high heat flow. (13)

The results of gravity and seismic studies have been published. by Couch (1975 and 1977). Gravity data indicates that the hot springs are in high gravity zones. (11) (14) 
The Oregon Department of Geology and Mineral Industries has conducted geothermal gradient and heat-flow measurements in thirty-eight holes in the Western Snake River basin. Numerous existing deep holes facilitated a relatively high density of geothermal data for the area. In addition, the Department drilled five deep holes for verification of trends. Results of the investigation outlined three areas of anomalously high heat flow: Cow Hollow, Willow Creek and South Fork Jacobsen Gulch. Data and conclusions have been presented in various publications since 1972 and have been summarized by Bowen, Blackwell and Hull (1977).

The most prominent anomaly is Cow Hollow situated about $13 \mathrm{~km}$ southeast of Vale. The anomaly appears to follow a linear trend $8 \mathrm{~km}$ long and $5 \mathrm{~km}$ wide. Within this area geothermal gradients range from 71 to $233^{\circ} \mathrm{C} / \mathrm{km}$ and heat-flow values range from 2.1 to 6.4 HFU. The anomaly appears to be related to leakage along the Willow Creek fault (Bowen and Blackwell, 1975).

Four wells with gradients greater than $90^{\circ} \mathrm{C} / \mathrm{km}$ and heat-flow values ranging from 2.0 to 2.8 HFU indicated the Willow Creek anomaly which is centered about $16 \mathrm{~km}$ northwest of Vale. Its relationship to the Cow Hollow anomaly is not currently understood.

The third area is the South Fork Jacobsen Julch anomaly, north of Vale. Two holes about $11 \mathrm{~km}$ apart indicated an area of high heat-flow. One well had a measured graident of $240^{\circ} \mathrm{C} / \mathrm{km}$ from the surface to $32 \mathrm{~m}$. The high gradient is due to warm water encountered in Owyhee Basalt and probably does not continue below the basalt. These results indicate that heat-f ?ow anomalies in the region are probably related to water circulation in the Owyhee Basalt and Grassy Mountain basalt aquifers, and to faulting which may disrupt the basalt aquifers. (15) (8) (9) 
... Exploration Activities:

The following private companies have undertaken exploration programs in the western Snake River basin. To secure competitive interests, results of these investigtions have not been publicly released.

\section{Chevron 0il - Neal-Bully Creek Area}

Completed drilling a shallow gradient holes in 1977 . Drilled a $305 \mathrm{~m}$. gradient hole in $1 / 78$.

Completed $5152 \mathrm{~m}$. holes of a 9 hole gradient drilling program in $10 / 78$.

Drilled a $610 \mathrm{~m}$. gradient hole in $9 / 78$.

\section{Amax Exploration - Bully Creek Area}

Planned to drill $3610 \mathrm{~m}$. gradient holes in late 1978.

\section{Ore-Ida Foods - Ontario}

Seismic and gravity studies conducted in late 1978. Gradient drilling is planned upon completion of geophysical surveys. 


\section{RESERVOIR CHARACTERISTICS}

SITE: VALE KGRA

..Reservoir Temperature: Vale Hot Springs

..Surface: $73^{\circ} \mathrm{C}$

(1)

$97^{\circ} \mathrm{C}$

..Subsurface: $160^{\circ} \mathrm{C}$

(1)

$180^{\circ} \mathrm{C}$

(3)

..Geochemical

$$
\begin{aligned}
\mathrm{SiO}_{2}: & 153^{\circ} \mathrm{C} \\
\mathrm{Na}-\mathrm{K}-\mathrm{Ca}: & 158^{\circ} \mathrm{C}
\end{aligned}
$$

..Flow Rates: 75 lpm

..pH: 7.47

..Fluid Chemistry:

(See following Table)

...Est imated Reservoir Heat Content: 810 MWe, (5) 500 MWe (USGS)

..Subsurface Area of reservoir:

$50 \mathrm{~km}^{2}$ estimated (1) 
...Chemical Analysis:

\begin{tabular}{|c|c|c|c|c|}
\hline $\begin{array}{c}\text { Vale } \\
\text { Hot Springs }\end{array}$ & $\begin{array}{c}\text { Beulah } \\
\text { Hot Springs } \\
\end{array}$ & $\begin{array}{c}\text { Neal } \\
\text { Hot Springs } \\
\end{array}$ & $\begin{array}{l}\text { Mitche } 11 \text { Butte } \\
\text { Hot Springs } \\
\end{array}$ & $\begin{array}{l}\text { Unnamed Hot Spring } \\
\text { Near Little Valley } \\
\end{array}$ \\
\hline 1,530 & 1,090 & 1,010 & 559 & 740 \\
\hline $\begin{array}{c}130 \\
19 \\
0.8 \\
310 \\
16 \\
0.28\end{array}$ & $\begin{array}{c}170 \\
24 \\
0.2 \\
200 \\
6 \\
0.24 \\
161 \\
1\end{array}$ & $\begin{array}{c}180 \\
8.8 \\
0.2 \\
190 \\
16 \\
0.3 \\
198 \\
1\end{array}$ & $\begin{array}{c}94 \\
4.6 \\
1 \\
110 \\
1.6 \\
0.03 \\
72 \\
3\end{array}$ & $\begin{array}{c}115 \\
3.2 \\
0.05 \\
160 \\
3.2 \\
0.11 \\
127 \\
1\end{array}$ \\
\hline $\begin{array}{c}100 \\
360 \\
6.1 \\
9.4 \\
73 \\
7.47 \\
75\end{array}$ & $\begin{array}{c}290 \\
55 \\
4.7 \\
4.7 \\
60 \\
7.56 \\
50\end{array}$ & $\begin{array}{c}120 \\
120 \\
9.4 \\
4.1 \\
87 \\
7.32 \\
90\end{array}$ & $\begin{array}{c}130 \\
28 \\
10.4 \\
0.49 \\
62 \\
8.69 \\
60\end{array}$ & $\begin{array}{c}110 \\
74 \\
6.8 \\
4.7 \\
70 \\
8.71 \\
550\end{array}$ \\
\hline 160 & 130 & 180 & 130 & 150 \\
\hline
\end{tabular}

Units $\mathrm{mg} / \mathrm{l}$ unless otherwise indicated

Location: Vale Hot Springs Beulah Hot Springs Neal Hot Springs Mitchell Butte Hot Springs Unnamed Hot Springs (near Little Valley)
- Sec. 20, T.18S., R.45E., W.M.

- Sec. 2, T.19S., R.37E. (west of Vale)

- Sec. 9, T.18S., R.43E. (slightly west of Vale)

- Sec. 12, T.21S., R.45E. (east of Vale)

- Sec. 30, T.19S., R.45E. (southwest of Vale) 


\section{LAND OWNERSHIP AND LEASING}

\section{SITE: VALE KGRA}

..Total KGRA acres: $\quad 22,998$ (approximately 14,565 federal acres and 8,433 private acres).

..Private land leased in KGRA and vicinity: undetermined acreage

Lease holders include: Magma Energy, Gulf 0il, LVO, Technology Internationa1, Standard 0 1, Geothermal Resources International

. State Land Leased: 1,280 acres to Amax Exploration in Vale KGRA; 640 acres to Chevron $0 i 1$ in Bully Creek area (outside KGRA)

..Land Leased in KGRA: 13,921 Federal Acres $\frac{1,280}{15,201} \quad \begin{array}{ll}\text { State Acres } \\ \text { Total }\end{array}$

..Highest Priced Lease: $\quad \$ 21.11 /$ acre

. Compétitive Leased Land:

$\$ /$ Acre

16.16

21.11

10.26

3.00

1.16

\section{Lessee}

Union $0 i 1$

Union $0 i 1$

Republ ic Geothermal

Geothermal Resources International

Amax Exploration
Acreage

4,486

3,525

1,347

2,560

2,003

.. Non-Competitive Leased Land (outside KGRA):

\begin{tabular}{l} 
Lessee \\
\hline Thermal Power \\
U.S. Geothermal \\
Amax Exploration \\
Chevron Oil \\
Earth Power \\
Various Individuals
\end{tabular}

Acreage
7,051
1,920
2,515
2,389
7,347
Undetermined

..Tentative Lease Sale Date: None Scheduled

. Number of Sales Offered but no bids: 3 tracts in $9 / 25 / 75$ sale 
.. Summary of Leasing Status and Needs:

Initially the U.S.G.S. designated 8,940 acres as the Vale KGRA. Additional geologic studies prompted them, on May 30, 1974, to include 11,535 acres in KGRA status. The BLM added 2,523 acres to the KGRA on December 18, 1974 due to overlapping non-competitive lease applications. Competitive lease sales were held on $6 / 17 / 74,9 / 15 / 75$ and $12 / 9 / 76$ where a total of 13,921 federal acres were leased. In addition, a significant amount of private property and public land adjacent to the KGRA have been leased.

The Republic Geothermal lease covering 1,347 acres issued on August 30,1974 was the first federal geothermal lease in Oregon. 


\section{GEOTHERMAL DEVELOPMENT STATUS}

\section{SITE: VALE KGRA}

-.Present Development Status:

Historically, Vale Hot Springs was used for public bathing in a natatorium.

Three greenhouses near Vale Hot Springs have been heated by geothermal energy for more than 20 years. Major crops have been bedding plants and cut flowers.

..Projected or Planned Development:

Ore-Ida Foods, Inc., a potato processing plant in Ontario (outside the KGRA) is participating with the U.S. Dept. of Energy in a cost shared demonstration project to prove the feasibility of utilizing geothermal resources in the food processing industry. Preliminary designs indicate that 55 percent of the plant's process energy requirements can be supplied by geo-heat. Initial exploration activities and test drilling are planned for 1978 with the system scheduled to be in operation by early 1980.

A five acre mushroom growing facility is beginning constructed in Vale adjacent to the present greenhouses. Geothermal energy will be used for cooling as well as space and process heating. This may be the first application of geothermal cooling in Oregon. It is anticipated that the facility will begin operation in 1979. 


\section{INSTITUTIONAL CONSIDERATIONS}

\section{SITE: VALE KGRA}

.. Institutional Requirements:

In 1974 Malheur County adopted the first preliminary geothermal ordinance in Oregon. The ordinance provides for issuance of permits, collection of fees and provides penalties for violations.

Private lands in the KGRA are zoned for exclusive farm use $(F-1)$, general farm use and rural residential. Under these zones, conditional uses are permitted for mineral exploration including geothermal exploration and development. Any entity wishing to conduct exploration or development on private land must submit plans to the Malheur Planning Commission for approval. Exploration within the Vale city limits requires the approval of the Vale City Planning Commission.

.. Agency and Public Attitudes:

From information gathered in interviews during the compliation of the EAR, both local governments and the general public in Vale, Ontario and Nyssa, are very supportive of geothermal development. People believe that directly or indirectly their communities will benefit from geothermal development. (4)

..Status of Requirements (i.e., EIA/EIS Requirements)

Environmental Analys is Report for the Vale KGRA released $5 / 74$ by the Vale district office of BLM.

EAR for Vale KGRA addition issued $5 / 75$.

EAR for proposed geothermal leasing in the Bully Creek area completed 2/76.

EAR for the Cow Creek geothermal interest area publ ished $9 / 76$.

EAR for proposed geothermal and oil and gas leasing in the Oregon Canyon area issued 8/77.

EAR for proposed geothermal and oil and gas leasing in the Northern Malheur Resource Area released 4/78. 


\section{ENVIRONMENTAL FACTORS}

\section{SITE: VALE KGRA}

.. CLIMATE - Hot dry summers and cold wet winters.

..Prevailing Winds: North to northwest

..Precipitation (Annual): $24 \mathrm{~cm}$.

$\therefore$ Average Temperature $10^{\circ} \mathrm{C}\left(50.8^{\circ} \mathrm{F}\right)$

Minimum: $-20^{\circ} \mathrm{C}\left(28^{\circ} \mathrm{F}\right)$

Maximum: $23.6^{\circ} \mathrm{C}\left(74.5^{\circ} \mathrm{F}\right)$

..Degree Days (Annual): 5879

..Relative Humidity (Seasonal Peaks)

Sumer: $30-40 \%$

Winter: $70-80 \%$

..AIR QUALITY: Quality is generally high. Bare land is susceptible to wind erosion which causes dust storms during dry periods.

..WATER QUALITY:

Quality of the Maiheur River is currently low and intensive irrigation use degrades it further. The river is seasonally warm, high in sediment and dissolved solids. Concentrations of basic nutrients, nitrogen and phosphorous, are high, particularly phosphorous. These high nutrient concentrations have stimulated heavy algal growth. Concentrations of dissolved solids average over $1,000 \mathrm{mg} / 1$. Dissolved oxygen concentrations fluctuate with low flows and algal activity.

Several ground water aquifers are within the KGRA. Water quality varies; some waters are not potable. Some deeper wells 152-183 m. produce warm water. Most potable wells in Vale are 6-12 m. deep. 


\section{. BIOLOGICAL}

..Dominant Flora:

Intermountain shrub steppe. Vegetation is the big sagebrush - grass association. This includes big sagebrush (Artemisia tridentata), bluebunch wheatgrass (Agropyron spicatum), Idaho fescue (Festuca idahoensis), and squirreltail (Sitanion hystrix), among others.

At higher elevations where sufficient moisture is present to sustain them the following tree species can be found; cottonwood and aspen (Populus spp.), willow (salix spp.), Juniper (Juniperus spp.) and Ponderosa Pine (Pinus ponderosa).

Private land in the KGRA is almost entirely agricultural. A variety of row crops are grown under flood irrigation sugar beets, onions, and potatoes predominate. A portion of the farmed area is in rotation between corn, alfalfa, grain, and row crops. (2) (4)

..Dominant Fauna:

Pronghorn antelope (Antilocarpa americana), mule deer (Odocoileus hemionus), Rocky Mountain elk (cervus canadensis) are the major mammals. Other species include insectivores, rodents, carnivores (coyote, cougar, foxes, skunk), raptorial birds and bighorn sheep.

Areas located in the vicinity of Malheur Reservoir, in the area west of Bully Creek, and along the upper Malheur Reservoir and the North and South forks are considered to be crilical deer winter habitat.

Large herds of wild horses are located in the western portion of the area. At the last BLM count, numbers totaled 1,593. The herds are capable of increasing their numbers by $20-25 \%$ annually. (2) (4)

..Endangered Species:

Flora: Hackelia cronguistii -

Collamia macrocalyx found on diatomaceous earth deposits located south of Westfall. 
The following may be in close proximity to the area:

Allium robinsonii, Eriogonum ochrocephalum spp. calcareum, Lorratium minus, Pediocactus simpsonii var. robustior, Penstemon seorsus, Polygonum heterosepalum, and Rhysopterus plurijugus

Fauna: Spotted frog (Rana pretiosa) Golden Eagle Bald Eagle

Peregrine Falcon

(2)(4) 


\section{TRANSPORTATION AND UTILITIES}

\section{SITE: VALE KGRA}

..Utility or Energy Transmission Corridors and Facilities

Two $138 \mathrm{kv}$ lines owned by the Idaho Power Company intersect at the Ontario substation.

A natural gas pipeline is in the area.

..Transportation Corridors or Facilities

Union Pacific Railroad-mainline running east-west and spur line running north.

Vale is at the junction of U.S. Routes 20 and 26 .

Interstate 80 is $24 \mathrm{~km}$ east of Vale.

Numerous city streets and secondary roads. 
POPULATION

SITE: VALE KGRA

..General Description of Population

Approximately $75 \%$ of the population of Malheur County $(24,600)$ 7 ives within a $40 \mathrm{~km}$ radius of the Vale KGRA. The principal towns are Ontario (population 8,950$)$, Vale $(1,900)$ and Nyssa $(3,000)$. Vale is the county seat and Ontario is the major trade center.

In general the county is undergoing a population shift from rural to urban living. Ethnic groups included in the population are Japanese Americans, Mexican Americans and Basques.

...Economics

..Present Land Use:

The economy is large dependent on agriculture and livestock production.

Agricultural products include sugar beets, onions, potatoes, corn, alfalfa and dairying. Food processing plants in Nyssa and Ontario are major contributors to the area's economy.

..Future Land Use:

Comprehensive land use plans for Malheur County were adopted in August 1973. 


\section{Western Snake River Plain Region References}

White, D. E. and Williams, D. L., eds., 1975, Assessment of Geothermal Resources of the United States - 1975: U.S. Geological Survey Circular 726.

(2) Bureau of Land Management, 1974, Vale Environmental Analysis Report - Geothermal Leasing: Vale District.

(3) U.S. Geological Survey, Geothermal Resources File (Geotherm) Revision 8, Computer Data File.

(4) Bureau of Land Management, 1975, Proposed Geothermal Leasing - Vale Addition Environmental Analysis Record: Vale District.

(5) Williams, F., et. al., 1977, Site-Specific Analys is of Geothermal Development - Data Files of Prospective Sites: The Mitre Corporation, V. 111.

(6) Mariner, J. B., Rapp, L. M., Willey, L. M. and Presser, T. S., 1974, The Chemical Composition and Estimated Minimum Reservoir Temperature of Selected Hot Springs in Oregon: U.S. Geological Survey Open File Report.

(7) Corcoran, R. E., Doak, R. A., Porter, P. W., Pritchett, F. I. and Privrasky, N.C., 1962, Geology of the Mitchell Butte Quadrangle, Oregon: Oregon Department of Geology and Mineral Industries GMS -2 .

(8) Bowen, R. G. and Blackwell, D. D., 1975, The Cow Hollow Geothermal Anomaly, Malheur County, Oregon: Ore Bin, $V$. 37, N. 7.

(9) Bowen, R. G., Blackwell, D. D., 1975, Geothermal Studies and Exploration in Oregon: Oregon Department of Geology and Mineral Industries Open File Report.

(10) Larson, K. and Couch, R., 1975, Preliminary Gravity Maps of the Vale Area, Malheur County, Oregon: Ore Bin, V. 37, N. 8.

(11) Couch, R., French, W., Gemperle, M. and Johnson, A., 1975, Geophysical Measurements in the Vale, Oregon Geothermal Resource Area: Ore Bin V. 37, N. 8.

(12) : Newton, V. C., J.r, and Corcoran, R. E., 1963, Petroleum Geology of the Western Snake River Plain Basin: Oregon Department of Geology and Mineral Industries $0 i 1$ and Gas Investigation 1. 
(13) Long, C. L., Hoover, D. G. and Bramsue, E., 1976, Audio-Magnetotelluric Apparent Resistivity Maps, Weiser, Idaho - Vale, Oregon: U.S. Geological Survey Open File Report 75-103.

(14) Couch, R. W., 1977, Analys is of Geophysical Data Pertaining to the Vale KGRA, Final Report to the Geothermal Research Program: U.S. Geological Survey Grant 14-08-0001-6-222.

(15) Bowen, R. G., Blackwell, D. D. and Hul1, D. A., 1977, Geothermal Exploration Studies in Oregon: Oregon

Department of Geology and Mineral Industries Miscellaneous Paper 19. 


\section{NORTHEAST OREGON GEOTHERMAL PLANNING REGION}

The U.S. Geological Survey has classified portions of northeastern Oregon as being prospectively valuable for geothermal resources (PGRA). This area covers parts of the Blue and Wallowa Mountains and the Grande Ronde and Baker and several smaller valleys.

Known resource data indicates that the area is not suitable for geothermal electrical generation. However, given the availability of thermal water matched with the existing economic base, the area is one of the most promising in Oregon for low temperature direct use applications of geothermal energy.

Limited research in the vicinity has been concentrated on the hot spring areas of the Grande Ronde Valley. This information is presented in the following chapter titled LaGrande PGRA. Baker County and surrounding hot spring areas were not investigated in depth as part of this report, but should be examined by those interested in further study. 


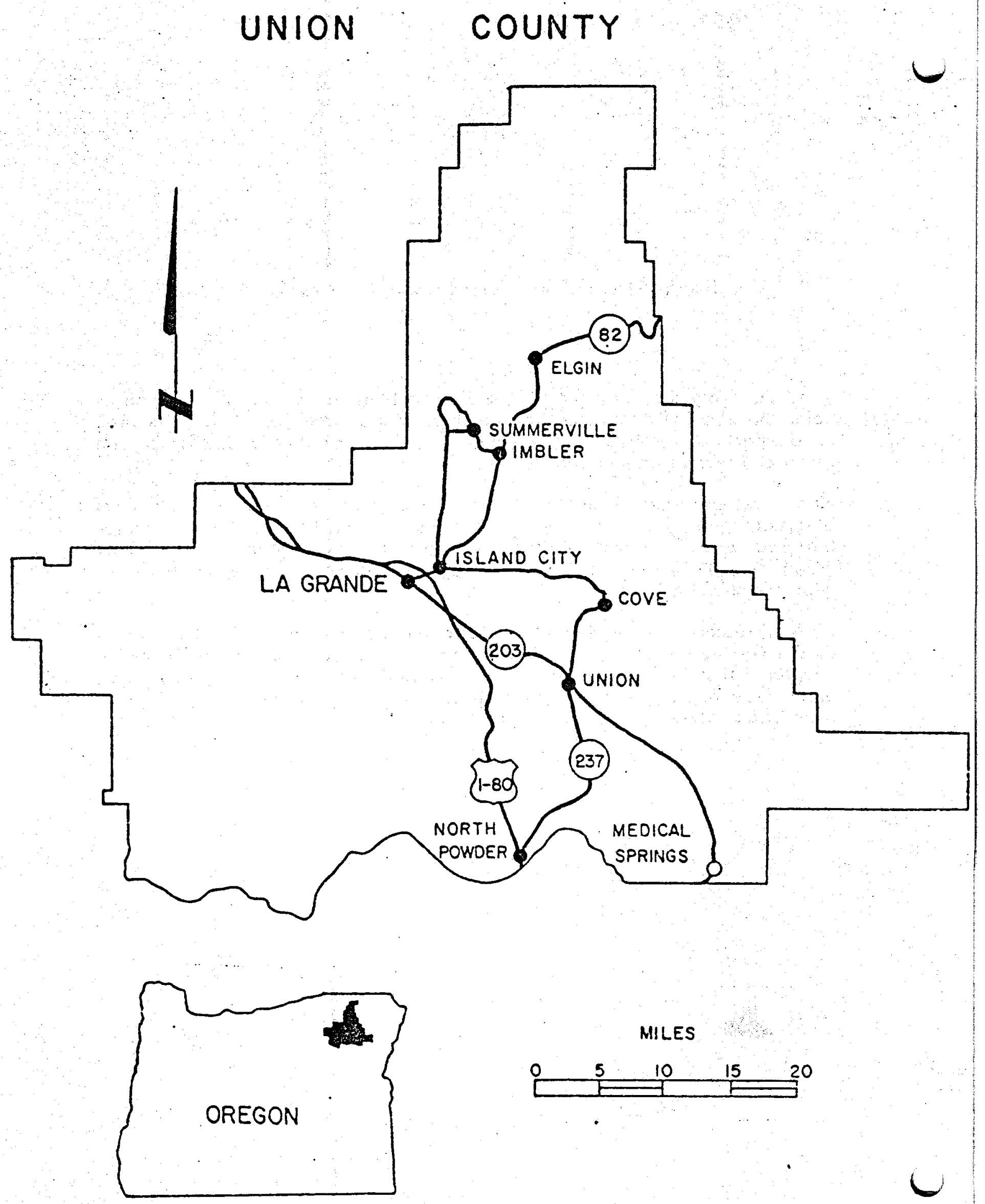




\section{BAKER \\ COUNTY}
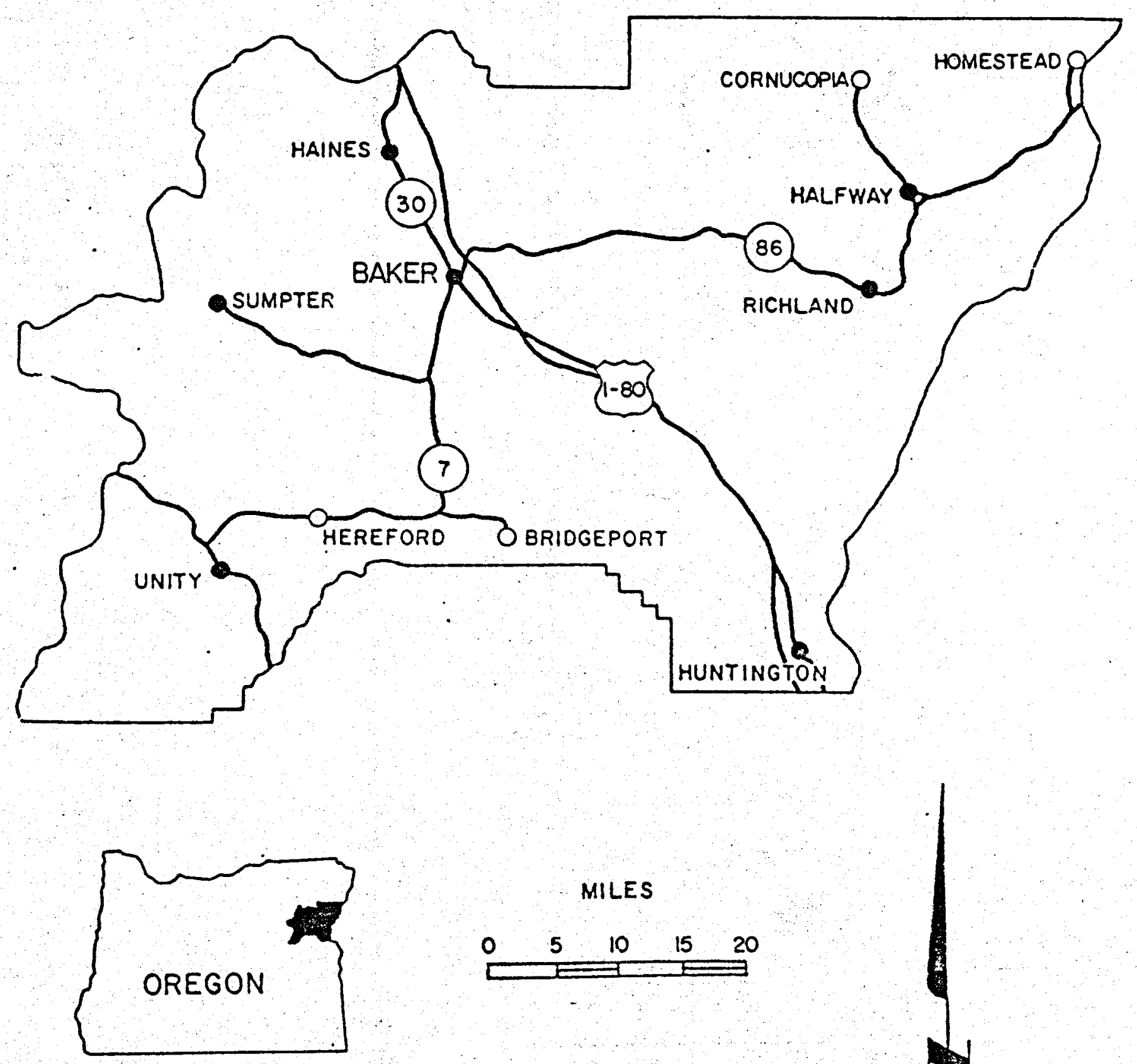

MILES

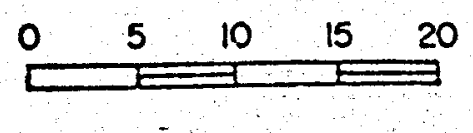




\section{GEOTHERMAL ENERGY EVALUATION}

\section{NON-ELECTRIC GEOTHERMAL ENERGY APPLICATIONS}

SITE: LA GRANDE PGRA, OREGON 


\section{LA GRANDE PGRA}

The Grande Ronde Valley is a complex faulted graben situated between the Wallowa, Elkhorn and Blue Mountains in northeastern Oregon. LaGrande, the county seat and largest population center, is located on the western margin of the valley in T.3S., R.38E, Willamette Meridan. Small towns scattered through the valley and LaGrande have a total urban population of about 15,360.

Geothermal resources in the Grande Ronde Valley are expressed at the surface by hot springs. The springs appear to be controlled by northwest-trending faults along the margins of the graben.

The most impressive springs are at Hot Lake about 16 kilometers southeast of LaGrande. The springs discharge 1,500 liters per minute of $80^{\circ} \mathrm{C}$ water. Estimated minimum reservoir temperature based on $\mathrm{Na}-\mathrm{k}-\mathrm{Ca}$ geochemical thermometers is $115^{\circ} \mathrm{C}$. Hot Lake spring is situated on a major northwest-trending bounding fault known as the Craig Mountain Fault. The fault extends in a northwesterly direction from south of Union, along the northeast flank of Craig Mountain intersecting the Hot Lake area. There is considerble disagreement among geologists concerning the possible extension of the fault under the valley alluvium beneath the city of LaGrande.

Southeast of Hot Lake is another apparently fault controlled thermal spring known as Medical Springs. The springs flow $200 \mathrm{lpm}$ at $60^{\circ} \mathrm{C}$. Geochemical techniques result in a minimum reservoir temperature of $67^{\circ} \mathrm{C}$.

Several other warm springs occur around the margins of the valley, but none has surface temperatures above $30^{\circ} \mathrm{C}$. In the vicinity of LaGrande several wells which penetrate basalt under the alluvium produce water with temperatures above the normal gradient.

Outside of the Grande Ronde Valley are two groups of springs located about 40 kilometers southwest of LaGrande. Hidaway Hot. Spring has a surface temperature of $38^{\circ} \mathrm{C}$ and flows at approximutely $570 \mathrm{lpm}$. Lehman Springs, used to heat water for a swimming pool, discharges $275 \mathrm{lpm}$ of $61^{\circ} \mathrm{C}$ water. Geochemically determined subsurface temperature at Lehman are estimated to be $98^{\circ} \mathrm{C}$. 
Geologic and geochemical characteristics of the Grande Ronde Valley, particularly the absence of post-Miocene volcanism, indicate that the probability of a shallow magmatic body acting as a heat source for the thermal springs is remote. The nature of the heat source is not known. Extensive folding and faulting in the valley could provide zones for water circulation and may control the location of the hot springs. Resource assessment is needed to confirm reservoir characteristics.

Preliminary investigations suggest the most promising use of the LaGrande area resources will be for moderate temperature direct use applications. Chemical analysis of the hot springs reveals low concentrations of silica and calcium and total dissolved solids which make the waters well suited for space heating, food processing, drying of grains and lumber, and greenhouse operations.

Hot Lake, approximately 16 kilometers from LaGrande, has the best potential for development of the identified resources. Thermal waters are currently being used for space heating in a small manufacturing building and a hotel. The resort is being refurbished and plans include expanded use of geothermal energy for space heating, spa facilities, greenhouses and an aquaculture project.

The large volume of water and estimated subsurface temperature of $120^{\circ} \mathrm{C}$ at Hot Lake are sufficient to meet the process heat requirements of an industrial park at the site. Potential uses include food processing, cold storage facilities, grain and crop drying, milk pasteurization and feed-lot operations. Energy consumers such as greenhouses, aquaculture ponds, and mushroom growing plants all of which require relatively low temperatures would make a cascaded system viable.

The existing agricultural and lumber complex in the LaGrande area could meet a considerable percentage of its energy demands with geothermal energy provided that the resource was readily available. These energy needs are currenily met with conventional fuels. Geothermal could supply process heat to the Island Park industrial site, lumber operations for kiln-drying, food processors requiring heated water and industries involved in drying organic. materials.

In addition to meeting industrial needs, geothermal energy could benefit the commercial and residential sectors with the establishment of a district heating system. Such a system is operating in Boise, Idaho and another is in the development stage at Klamath Falls, Oregon. 
The first step might be to set up a demonstration project for district heating. Initially, it could provide space and water heating to Eastern Oregon State College, three public schools, county courthouse, hospital, and a semi-public office building. These structures emcompass almost 900,000 square feet and are all concentrated on the south side of LaGrande. Representatives of these institutions have taken an active interest in the possibility of geothermal heating.

However, unless the resource at Hot Lake could be economically delivered to LaGrande, a closer resource must be proven to realize industrial and district heating use of geothermal energy. Exploration activities such as geologic mapping and deep gradient hole drilling should be conducted to determine if the Craig Mountain Fault runs under the lacustrine deposits beneath LaGrande. If a suitable resource is discovered, given the favorable local attitudes, presence of end users and compatibility with land use plans, geothermal development could be realized in the short term. 
SITE LOCATION AND PHYSICAL DESCRIPTION

SITE: LA GRANDE PGRA

..Latitude: $45019^{\prime} \mathrm{N}$

..Longitude: $118^{\circ} 5^{\prime} \mathrm{W}$

..Rectilinear: T.3S., R.38E

..County: Union

..Adjacent Counties: Baker, Gilliam, Umatilla

..Map Reference: U.S.G.S. Topographic - Craig Mtn., Oregon 1:24,000 AMS - Grangeville, Idaho - Oregon - Washington $1: 250,000$

.. Topography

LaGrande is situated in the Grande Ronde Valley which. is a broad, low lying valley in the Blue Mountain physiographic. region. The valley is bordered to the east by the Wal lowa Mountains and to the west by the Elkhorn and Blue Mountains. The Grande Ronde is an irregular, oval-shaped area of low relief approximately $39 \mathrm{~km}$ long and $29 \mathrm{~km}$ wide. Level plains, alluvial fans and terraces are present on the valley floor. The Grande Ronde River flows through the Valley. Elevations in the Grande Ronde Valley range from 822 to 914 meters.

..Present Land Use:

Major land uses are: fnrest, agriculture and urban. Ladd Marsh, between LaGrande and Hot Lake, is a State Wildlife Management area covering 2,418 acres.

..Future Land Use P.1ans:

Expanded acreage for rural residential, commerical and industrial developments. Continued use of forested and agricultural land.

.. Aesthetics:

The Grande Ronde Valley surrounded by the Wallowa, Elkhorn and Blue Mountains is a highly scenic area.

..Historical/Archaeological Significance:

The Oregon Trail crosses the valley floor. 
..Geologic Description:

The oldest exposed rocks in the area are Paleozoic. These consist of metavolcanic and metasedimentary rocks. The metasedimentary units, known as Clover Creek Greenstone, are of conglomerate, limestone, chert and shale. Estimated thickness is 915 meters. The metavolcanics consist of altered tuffs and basaltic to rhyolitic flows. Mesozoic intrusives of grabbo and quartz diorite composition intrude the Paleozoic metavolcanics and metasediments.

A major unconformity separates the Permian - Triassic base units from the Tertiary clastics of the Clarno Formation. Of Miocene age, the Clarno Formation is about 122 meters thick and consists of tuff breccia, silicified tuff and andesite flows.

Overlying the andesitic rocks is Miocene Columbia River Basalt, primarily composed of basalt flows. Thickness is approximately 1,800 meters.

The Columbia River Basalt is overlain by olivine basalt about 100 meters thick. Miocene platy andesite, in turn, overlies the olivine basalt. Quaternary volcanic rocks are not known to exist in the area.

Lacustrine materials composed of unconsolidated clay, silt and sand of Eocene to Pleistocene age have been deposited in the graben valleys. The permeable deposits are now ground water aquifers. The bedrock patterns in the val leys have been concealed by accumulated deposits greater than 610 meters deep in some locations.

\section{Structure}

The Grande-Ronde Valley is a complex folded ard faulted graben surrounded by four major structural-lithologic regions. These include the Columbia Plateau, the Wallowa-B lue Mountain Uplifts, the Snake River Depressions and the Idaho Batholith.

Along the east and west valley margins are numerous northwest-trending faults which are credited with the downwarping of the Grande Ronde basin. Hampton and Brown (1964) suggest that the major faulting which formed the graben occurred during the Pleistocene. Total vertical displacement along the western border is approximately 1000 meters, and 1220 meters on the eastern side. Individual faults have vertical displacements ranging from 60 to 460 meters. Moving away from the graben margins, vertical displacement decreases. 
The northern extension of Craig Mountain has been downdropped about 425 meters by a series of parallel faults. These faults intersect the northwest-trending Hot Lake fault at Hot Lake Springs. $(3)(4)(5)(6)(7)$

\section{-.Geophysical and Gradient Data Summary:}

The Oregon Department of Geology and Mineral Industries measured temperature gradients in over a dozen pre-drilled wells in the LaGrande area. Only one shallow well (45 meters) had an average gradient above the normal for the region.

In 1974, Magma Power drilled an 831 meter exploration well one ki lometer southeast of Hot Lake Springs. The measured gradients were apparently not encouraging because Magma returned all of its leases in the area. Speculation has been raised that temperature gradients may be more favorable than were recognized since the well had not reached equilibrium when the measurements were made.

AMAX Exploration Company has conducted a seismic noise survey near LaGrande. Results indicate that the south Grande Ronde Valley is seismically inactive. (4)

AMAX has also tested 14 holes for heat-flow measurements. An anomaly extending $5 \mathrm{kilometers}$ from Hot Lake south to Union with values as high as 2.9 heatflow units was revealed. Analyses. suggest that the anomaly is consistent with a horizontal northeast-trending hot water flow through the valley. AMAX postulates that the lateral water flow originates from the craig Mountain Fault and is conducted by interflow zones in Columbia River Basalt. (4)

...Geologic Hazards:

Landslides have occurred in units of Columbia River Basalt forming steep cliffs, and in colluvial deposits on the valley margins. 


\section{RESERVOIR CHARACTERISTICS}

SITE: LA GRANDE PGRA

..Reservoir Temperature - Data from Hot Lake Hot Springs

..Surface: $80^{\circ} \mathrm{C}$

..Subsurface: $120^{\circ} \mathrm{C}$

..Geochemical - $\mathrm{SiO}_{2}:{ }_{\mathrm{Na}-\mathrm{K}-\mathrm{Ca}:}{ }^{\mathrm{S}^{\circ}} \quad 0^{\circ} \mathrm{C}$

..Flow Rates: $1,5001 \mathrm{pm}$

..pH: 9.21

..Total Dissolved Solids: $526 \mathrm{mg} / \mathrm{l}$

..Fluid Chemistry:

Hot Lake Springs

Location: T.4S., R.39E., Section 5 SE 1/4

Reference

Units

Specific Conductance (micromhos)

Silica

Calcium

Magnes ium

Sodium.

Potássium

Lithium

Bicarborate

Carbonate

Sulfate

Chloride

Flouride

Boron

Temperature $\left({ }^{\circ} \mathrm{C}\right)$

$\mathrm{pH}$

Flow
10

$\mathrm{mg} / 1$

688

48

4.9

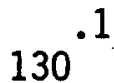

2.7

.03

75

12

56

140

1.7

2.9

80

9.21

$1500 \mathrm{l} / \mathrm{min} . \quad 1,700 \mathrm{gpm}$

11

4.7

.2

142.7

2.1

.06

20

40

49

237.5

85

9.8

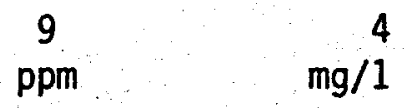

TDS

\section{$1500 \mathrm{l} / \mathrm{min}$}


Medical Hot Springs

Location: T.6S., R.41E., Section 25 NE 1/4

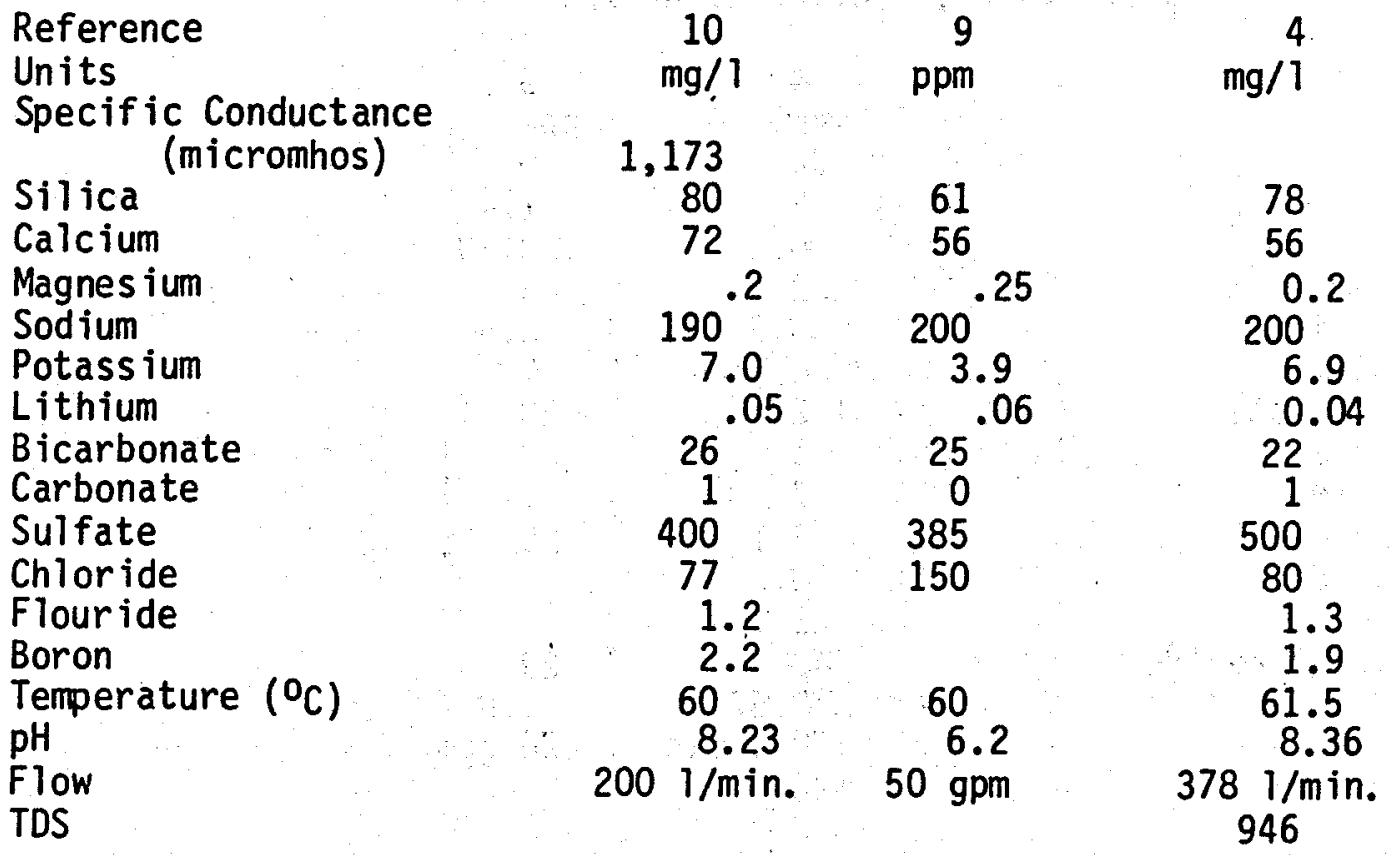

Radium Hot Springs

Location: T.7S, , R.39E., Section 28 NE $1 / 4$ (outside Grande Ronde Valley)

Reference

Units

Specific Conductance

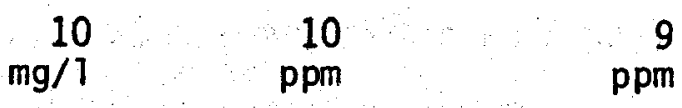
(micromhos)

290

Silica

Calcium

Magnes ium

Sodium

Potassium

Lithium

Bicarbonate

Carbonate

Sulfate

Chloride

Flouride

Boron

$\begin{array}{rr}290 & 290 \\ 78 & 80\end{array}$

Temperature $\left({ }^{\circ} \mathrm{C}\right)$

$\mathrm{pH}$

Flow

Collection Date

1.5

0.1

58

1.1

0.01

86

27

34

17

1.3

0.42

58

9.56

$1100 \mathrm{l} / \mathrm{min}$.

1972
1.6

0

63

2

5

47

31

17

1

57.2

9.7

$230 \mathrm{gpm}$

1955
48

3.1

0.2

56

0.8

25

60

23

12.5

57

7.0

$300 \mathrm{gpm}$ 
Cove Hot Spring (Swimming pool)

Location: T.3S., R.41E., Section 22 NW 1/4

$\begin{array}{lcc}\text { Reference } & 4 & 9 \\ \text { Units } & \mathrm{mg} / 1 & \mathrm{ppm} \\ \text { Silica } & 36 & 0 \\ \text { Calcium } & 2 & 1.4 \\ \text { Magnesium } & 0.1 & 0.20 \\ \text { Sodium } & 32 & 66 \\ \text { Potassium } & 0.8 & 0.4 \\ \text { Lithium } & 0.01 & 0 \\ \text { Bicarbonate } & 112 & 20 \\ \text { Carbonate } & 1 & 20 \\ \text { Sulfate } & 7 & 5 \\ \text { Chloride } & 6.1 & 25 \\ \text { Flouride } & 0.3 & \\ \text { Boron } & 1 & \\ \text { Temperature }\left({ }^{\circ} \mathrm{C}\right) & 42 & 29 \\ \text { pH } & 8.57 & 9.8 \\ \text { Flow } & 11581 / \mathrm{min} & 226 \mathrm{gpm} \\ \text { TDS } & 196 & \end{array}$

..Estimated Reservoir Heat Content: $.1 \times 10^{18} \mathrm{Cal}$

(1)

..Subsurface Area of Reservoir: Estimated $1.5 \mathrm{~km}^{2}$ 


\section{LAND OWNERSHIP AND LEASING \\ SITE: LA GRANDE PGRA}

..Land Ownership: Private

..Land Leased:

$$
\begin{aligned}
& \text { Federal (acres) - None } \\
& \text { State (acres) - None } \\
& \text { Private (acres) - Unknown }
\end{aligned}
$$

.. Summary of Leasing Status and Needs:

Leasing proposals will have to be negotiated with private land owners. 


\section{GEOTHERMAL DEVELOPMENT STATUS \\ SITE: LA GRANDE PGRA}

..Present Development Status: .

Cove

- Geothermal heated public swimming pool. Boise Cascade tree seedling greenhouses, 7,300 sq. ft., are heated from the Cove Hot Springs at the Cove swimming pool.

Hot Lake

- Space and pool heating at Hot Lake Hoter. Space heating at small irrigation manufacturing facility.

Medical Springs - Hot springs resort.

..Projected or Planned Development:

Hot Lake Hotel is being developed as a destination resort.

It is likely that geothermal energy will be used extensively in the renovated hotel, barn, and spa, and in greenhouse and aguaculture applications.

An industrial park is also being considered at the Hot Lake site. 


\section{INST ITUTIONAL CONSIDERATION}

\section{SITE: LA GRANDE PGRA}

\section{.. Institutional Requirements}

Certain exploration and development activities may require a conditional use permit from the county.

Two small areas south of LaGrande have been designated as unsuitable for geothermal development by the Oregon Energy Facility Siting Council. The Council has siting authority over geothermal power plants which produce 25 Mw or more and geothermal pipelines greater than six inches in diameter and five $\mathrm{mi}$ les in length. (11)

.. Agency and Public Attitudes

Local attitudes appear favorable to geothermal development.

The Union County Plan specifically states "...potential geothermal resources will be protected from encroachment which may limit development..." in the future and that "... renewable energy resources, such as geothermal will be used in preference to non-renewable resources whereever possible."

(9) 


\section{ENVIRONMENTAL FACTORS}

\section{SITE: LA GRANDE PGRA}

\section{. CLIMATE}

..Prevailing Winds:

During the winter, prevailing southeastern winds commonly gust to 50 miles per hour.

..Precipitation (Annual): $51 \mathrm{~cm}$.

..Average Temperature $-9.72{ }^{\circ} \mathrm{C} \quad\left(49.5^{\circ} \mathrm{F}\right)$

Minimum:
Maximum: $\quad 21 . .^{\circ} \mathrm{C} C\left(30.6^{\circ} \mathrm{C}\right)$
$\left(70.3^{\circ} \mathrm{F}\right)$

..Degree Days (Annual): 6069

..WATER QUALITY:

Groundwater is obtained from lacustrine deposits and alluvial fans in the valley and from the Columbia River Basalt. Yields are higher in the Columbia River Basalt averaging $700 \mathrm{gpm}$.

Precipitation is the primary source of recharge.

Water quality is generally good. The Grande Ronde River has a hardness of about 20 ppm. Groundwater ranges from about $18 \mathrm{ppm}$ in Columbia River Basalt to $93 \mathrm{ppm}$ in the alluvium in hardness.

(3) 


\section{. BIOLOGICAL}

..Dominant Flora:

Valley areas are dominated by Big sagebrush/bluebunch wheatgrass associations including bunch grass and scattered stands of juniper.

Ponderosa pine, lodgepole pine and Western larch communities cover the intermediate elevations.

At higher elevations the predominate vegetative cover is Douglas fir forest.

..Dominant Fauna:

Elk, mule deer, waterfowl, grouse, pheasant and numerous non-game species.

Rocky Mountain elk (Cervus canadensis nelsoni)

Mule deer (Odocoileus hemionus columbianus)

White tailed deer (Odocoileus virginianus ochrourus)

Ladd Marsh is managed by the state for waterfowl habitat.

...Endangered Species

Flora: Unknown 


\section{TRANSPORTATION AND UTILITIES}

\section{SITE: LA GRANDE PGRA}

..Utility or Energy Transmission Corridors and Facilities

Bonneville Power Administration maintains a $230 \mathrm{kv}$ transmission line and the Gekeler substation on the outskirts of LaGrande. Two other transmission lines, $69 \mathrm{kv}$ and $138 \mathrm{kv}$, cross Union County connecting the area to the Pacific Northwest power grid.

Natural gas pipeline is located approximately $3 \mathrm{~km}$ south of LaGrande.

\section{..Transportation Corridors or Facilities}

Interstate 80 connecting LaGrande with Pendleton and Portland to the West, and Boise to the east.

Highways 203, 237, and 82 plus numerous secondary roads.

Union Pacific Railroad - two lines, one from the northeast and one from the southeast, meet in LaGrande and head northwest. Amtrak passenger rail service. 
POPULATION

SITE: LA GRANDE PGRA

\section{...General Description of Population}

Union County had a 1977 population of 22,400 , most of which is concentrated in the Grand Ronde Valley. A shift in growth patterns over the last five years has the rural areas growing faster than urban areas. Projections estimated a population of 22,800 in 1980 and 24,677 by 1995 .

Estimated 1976 population figures and distances from LaGrande are below:

$\begin{array}{lrr}\text { LaGrande } & 11,140 & \\ \text { Union } & 2,160 & 21 \mathrm{~km} \mathrm{SE} \\ \text { Elgin } & 1,735 & 30 \mathrm{~km} \text { NE } \\ \text { Island City } & 545 & 4 \mathrm{~km} \mathrm{NE} \\ \text { Cove } & 480 & 22 \mathrm{~km} \mathrm{E} \\ \text { Imbler } & 235 & 18 \mathrm{~km} \mathrm{NE} \\ \text { Summerville } & 115 & 20 \mathrm{~km} \mathrm{~N}\end{array}$

...Economics

..Present Land Use: Principal economic activities are: agriculture (grains, livestock, grass seed, fruit and peas), manufacturing (lumber and wood products), government (federal, state and local), and retail trade (including tourism). The major employers are the lumber and wood products industry, primarily Boise Cascade and Terry Trailer, and retail trade.

Lumber mills at Elgin, Union, Cover and LaGrande prccess timber from the surrounding forests, and Imbler is the center of a large grass seed industry. (2)

Total area of Union County is $1,301,760$ acres, of which 71.3 percent is timber land, 14.7 percent agricultural land, and 12.8 percent range land. The approximate remaining 16,000 acres includes about 6,000 acres each of rural residential and urban areas, and the balance in water bodies and public uses not within city vicinities. About 65 percent of the county's industrial development is based in LaGrande and in the industrial park northeast of Is land City.

(2) 
.. Future Land Use:

Land use plans anticipate that rural residential acres will increase. The largest expansions for commerical development are planned for Island City (100 acres) and LaGrande (400 + acres). Greatest industrial growth is planned for Elgin ( 300 acres) Island City (industrial park $-200+$ acres) and LaGrande (670 acres). (2) 
Northeastern Oregon Region References

(1) White, D. E. and Williams, D. L., eds., 1975, Assessment of Geothermal Resources of the United States-1975: U.S. Geological Survey Circular 726.

(2) Union County Overall Economic Development Program Committee, 1977, Union County - Overall Economic Development Program: Union County, LaGrande, Oregon.

(3) Hampton, E. R. and Brown, S. G., 1964, Geology and Groundwater Resources of the Upper Grande Ronde River Basin, Union County, Oregon: U.S. Geological Survey Water Supply Paper 1497.

(4) Dellechaie, F., 1978, A Geological and Hydro-Geochemical Study of the LaGrande Area, Union County, Oregon: Transactions, Geothermal Resources Council, V. 2.

(5) Portland General Electric, 1976, Prospects for Electric Power Generation from Geothermal Energy: Internal Report to Management.

(6) Walker, G. W., 1973, Reconnaissance Geologic Map of the Pendleton Quadrangle, Oregon and Washington: U.S. Geological Survey Miscelleneous Geologic Investigation Map I-727.

(7) Prostka, H. J., 1962, Geology of the Sparta Quadrangle, Oregon: Oregon Department of Geology and Mineral Industries Map.

(8) Hul1, D. A., Blackwell, D. D., Black, G. L., 1979, Geothermal Gradient Data: Oregon Department of Geology and Mineral Industries Open File Report 0-78-4.

(9) Huggins, Rich, editor, 1978, Northeast Oregon Geothermal Potential: Eastern Oregon Community Development Council, LaGrande, Oregon.

(10) U.S. Geological Survey, Geothermal Resources File (Geotherm) Revision 8, Computer Data File.

(11) Oregon Nuclear and Thermal Energy Counci1, 1974, State-Wide Siting Task Force Report: Oregon Department of Energy. 
)

\section{Cascades Geothermal Planning Region}

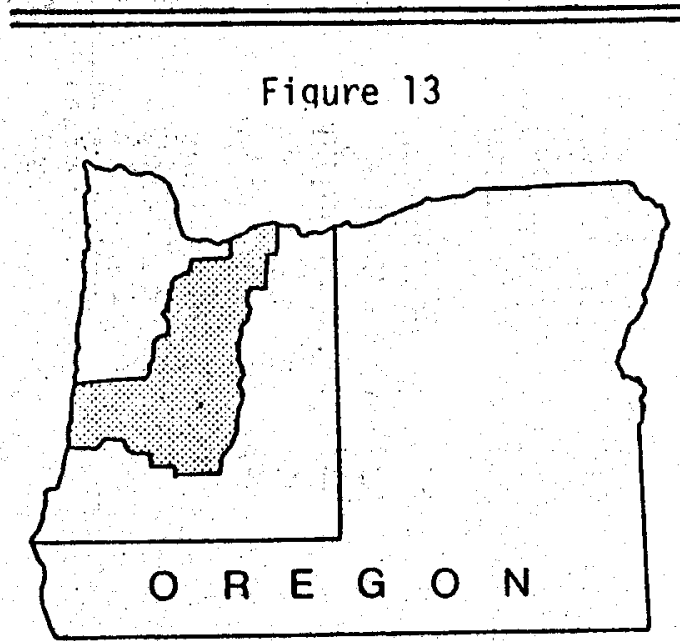

Known Geothermal Resource Area

Planning Region

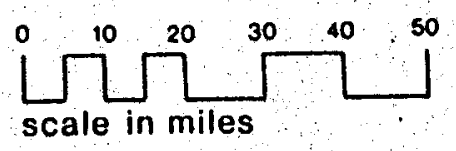

$\overbrace{\text { NORTH }}$

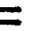

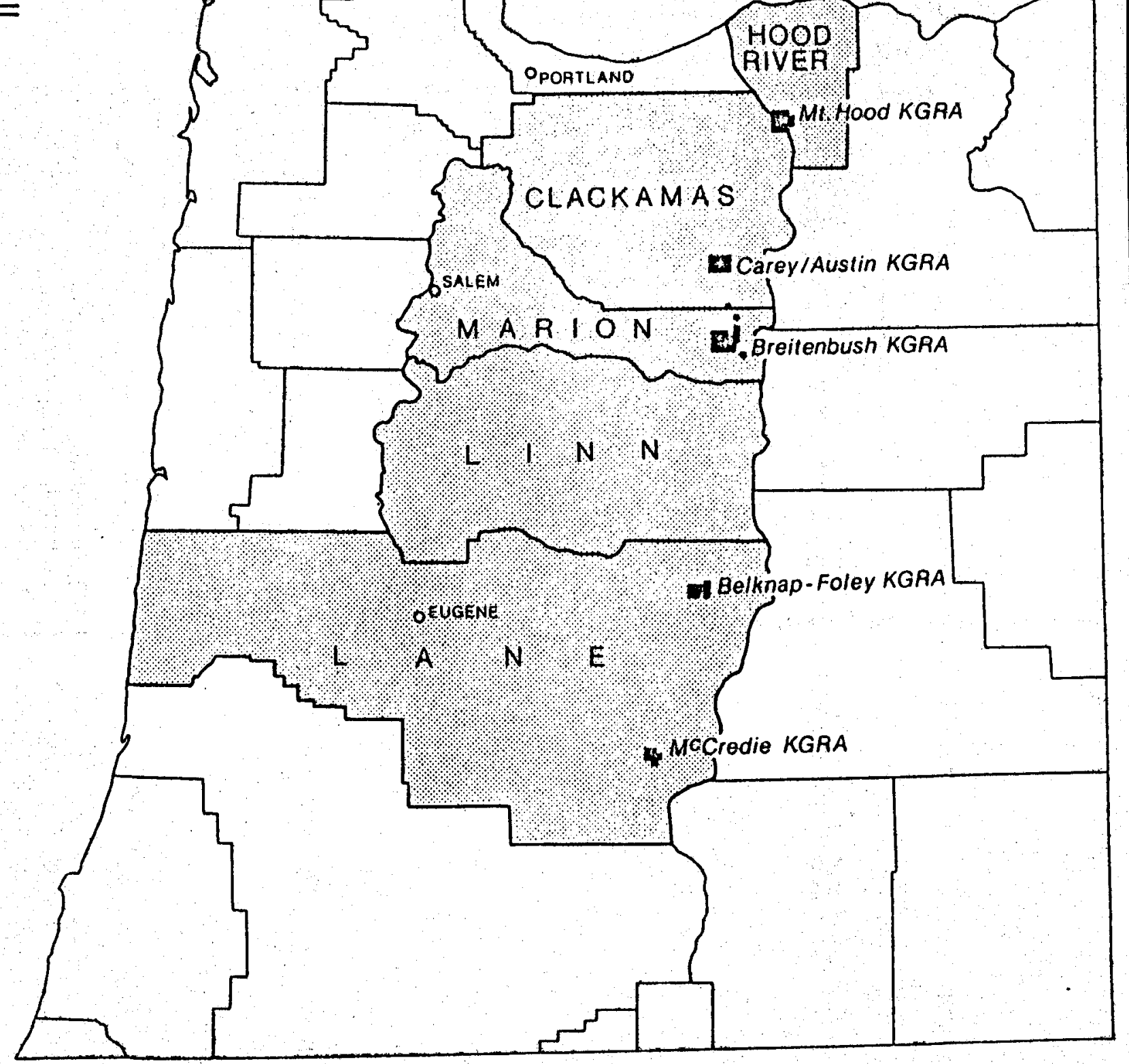




\section{CASCADE MOUNTAINS GEOTHERMAL PLANNING REGION}

The Oregon Cascade Range is divided into two distinctive belts, the Western Cascades and the High Cascades. The High Cascades, which lie to the east, are composed of young volcanic rocks which show little evidence of erosion or deformation. Several glaciated volcanic peaks dominate the High Cascades and includes the highest peak in Oregon, Mount Hood, elevation 3,427 meters (II,235 feet). The Western Cascades are much older and more deeply dissected than the High Cascades resulting in a more rugged terrain with greater local relief. Western Cascade topography is characterized by steep east-west ridges divided by valleys cut by the Clackamas, Santiam, Mickenzie, and Willamette River systems.

The Cascade Mountains are sparsely populated. Small communities are located in the valleys and are largely dependent on the forest products industry for their livelihood. The area is used extensively for recreational activities and serves as important watersheds for the Willamette Valley urban centers.

In the broad perspective, population concentrations in the Willamette Valley would benefit the most from geothermal development in the Cascades, if the resources prove capable of meeting a portion of energy demand and environmental concerns can be mitigated. Approximately two-thirds of Oregon's population (2,472,000-1978 state total estimate) lives in the Willamette Valley including the major metropolitan areas of Portland, Salem and Eugene. As well, much of the state's economic activity is centered in the Willamette Valley.

The five counties adjacent to the Cascade geothermal areas most likely to benefit from commerical development include: Hood River, Clackcmas, Marion, Linn and Lane. Combined 1978 population estimates for these areas totals 773,000 . It should be noted, however, that these counties cover a broad area not all of which would be effected by even large scale geothermal development. The principal industries in the planning region are lumber, agriculture, manufacturing, food processing and recreation.

To discuss the potential of geothermal development in the Cascade Range, this report divides the region on the basis of physiographic character istics, into two areas, High Cascades and Western Cascades. 


\section{2}


SITE: MT. HODD, KGRA, OREGON 


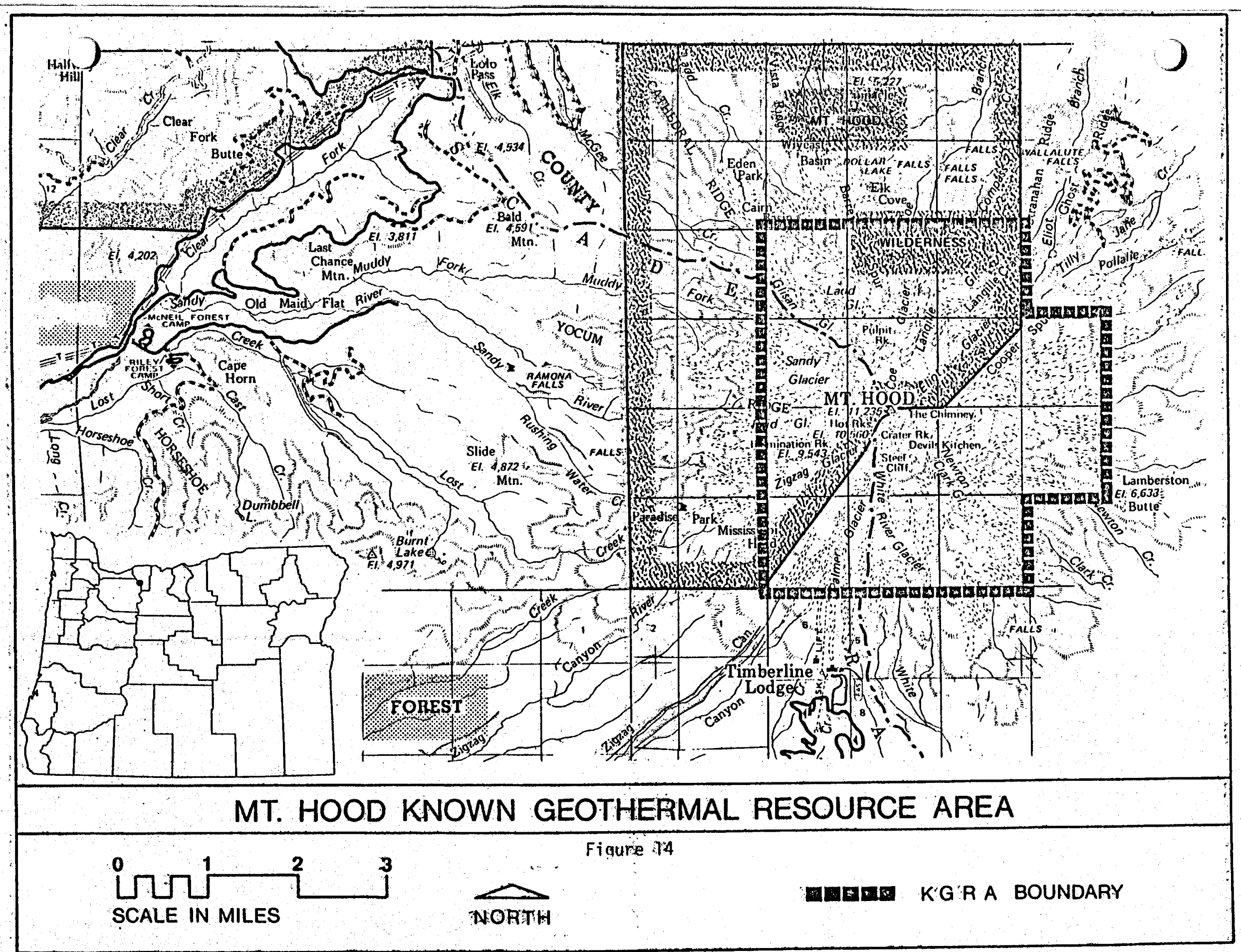


High Cascades Region

\section{MOUNT HOOD KGRA}

The Mount Hood KGRA is situated within T.2S., R.9E., Willamette Meridian (W.M.), Clackamas and Hood River Counties, Oregon. Government Camp, the closest community, is 12 kilometers south of Mt. Hood. Portland is approximately $80 \mathrm{~km}$ northwest of the KGRA.

At 3,427 meters elevation, Mt. Hood is the highest peak in Oregon and serves as a landmark from Portland and areas east of the Cascades. The mountain is a young volcanic cone which has been highly dissected by glaciation on the upper slopes and modified by stream activity on the lower flanks.

The KGRA and the majority of surrounding land is owned by the Federal Government and managed by the U.S. Forest Service as part of the Mt. Hood National Forest. Land use is focused on the area's natural resources with timber production and recreation of primary importance. The Mt. Hood National Forest Land Management Plan (1977) proposes to increase timber production and recreational opportunities while maintaining the scenic qualities of the mountain area. The environmental statement for the plan addresses geothermal potential only in general terms.

The small portion of private land in the Mit. Hood vicinity is concentrated along Highways 26 and 35. Population levels are low, but tend to fluctuate seasonally. The small percentage of private land available for residential development results in population densities approaching urban or suburban levels in the small existing communities. The population in these areas is expected to double or triple in the next 20 years.

Geothermal resource potential is indicated by surface manifestations of thermal activity at Swim Warm Springs near Government Camp, and northeast of Crater Rock near the summit of Mt. Hood where approximately 20 fumarolic vents are releasing gases to the atmosphere. Temperatures of the fumaroles range from 50 to $90^{\circ} \mathrm{C}$. Swim Warm Springs discharge 25 gallons per minute (gpm) at a temperature of $27^{\circ} \mathrm{C}$. Estimated subsurface reservoir temperature for Mt. Hood is $125^{\circ} \mathrm{C}$. 
An extensive three year geothermal resource assessment of Mt. Hood was begun in 1977 as a cooperative effort between various federal agencies and the Oregon Department of Geology and Mineral Industries. Shallow temperature gradient drilling and geophysical surveys including; aeromagnetic, microseismic, infrared, magnetotelluric and telluric resistivity, and thermal modeling were begun in 1977. Deeper drilling, continued geophysical studies and additional gradient hole drilling are scheduled in late 1978. Expenditures for the resource assessment represents the largest geothermal research project to date in Oregon. Results of the project will not only supply meaningful data on the realistic geothermal potential of Mt. Hood, but will serve to broaden the knowledge and understanding of Cascade volcanoes in general.

Interest in developing the Mt. Hood geothermal resource has been keen. In September 1977 the first geothermal lease on U.S. Forest Service land was issued to R.L.K. \& Company, operator of Timberline Lodge. A shallow gradient hole was drilled east of the Lodge, but difficult drilling problems caused subsequent abandonment. Apparently not discouraged, the company drilled a second test well near the Lodge, which was spudded in August 1978. The hole is permitted to a depth of 609 meters $\left(2,000 \mathrm{ft}_{\mathrm{t}}\right)$; and as of early October 1978 drilling had reached below 335 meters $(1,100 \mathrm{ft}$.$) .$

If suitable temperatures and flow rates are indicated from test drilling, the proposed plan is to supply space heating to Timberline Lodge and the anticipated facilities expansion, swimming pool heating, and for snow melting on roads and parking areas at the Lodge. It has been estimated that the conversion to a geoheating system would be cost effective if water near $93^{\circ} \mathrm{C}$ $(200 \mathrm{~F})$ could be obtained. A geothermal heating system could displace the 38,000 gallons of heating oil per month for Timberline Lodge, which ranks as the largest single-building oil consumer in Oregon.

The Northwest Natural Gas Company (NWNG) is also interested in development of the Mt. Hood geothermal resource. The company holds assigned non-competitive leases on 7,680 acres (and possibly more).

In late 1977 NWNG drilled a temperature gradient hole to a depth of 564 meters : $(1,850 \mathrm{ft}$.$) at Old Maid Flat west of Mt. Hood. This well was$ incorporated into the federal-state resource assessment program and was deepened to 1,220 meters $(4,003 . \mathrm{ft}$.$) during July and August 1978$. Temperature probes indicated a bottom hole temperature of $80^{\circ} \mathrm{C}$ (176 ${ }^{\circ} \mathrm{F}$ ) shortly after drilling ceased. This reading is subject to change since the well had not reached equilibrium temperature. Another temperature log which should result in a representative bottom hole temperature was planned for mid October 1978. Results of this deep test drilling are being evaluated to examine the feasibility of Northwest Natural Gas Company's proposed heating project. 
The objective of the exploration operation is to locate a sufficient resource to justify construction of a 48 inch pipeline over a $69 \mathrm{~km}$ ( $43 \mathrm{mile}$ ) distance to Portland for industrial processing and space heating. NWNG estimates that if a resource capable of producing $25,000 \mathrm{gpm}$ of clean water at a temperature of $74^{\circ} \mathrm{C}\left(165^{\circ} \mathrm{F}\right)$ is discovered, it can be delivered to major users in the Portland area at less than the cost of the equivalent energy from natural gas or fuel oil. Thus far, the results from test drilling appear favorable for satisfying the temperature requirement; however, essentially no water flows were encountered during drilling. Further and/or deeper drilling may be necessary to locate fluids. The target is the Columbia River Basalt Formation which has proven to be a high quantity and quality aquifer elsewhere in Oregon and Washington.

The drilling at Old Maid Flat encountered Columbia River Basalt at a depth interval from 618 to 991 meters, similiar to the thickness of the Columbia River Basalt exposed in the Clackamas River area. The group was not all basalt, however, but had large sections of andesite and andesitic tuff. Additional tests are continuing to better define the Mt. Hood geologic setting.

The Portland General Electric Company (PGE) has expressed interest in the Mt. Hood geothermal resource and has obtained non-competitive loutside the KGRA) leases on 8,945 acres on the east side of the mountain. Considering the high cost of geothermal exploration, it appears likely that PGE will await the results of the cooperative resource assessment project before undertaking an investigation of its own.

The drilling programs at Timberline Lodge, Old Maid Flat and the eleven shallow gradient holes around the base of the mountain are all part of the resource assessment project. Therefore, resulting data will be available as public information.

Mt. Hood appears to have good potential for non-electric geothermal applications. Possible electrical generation does not appear likely now because of the lack of an identified sufficient resource and given the sensitive environmental concerns for the area.

Assuming the Northwest Natural Gas Company's exploration program is successful and that environmental and land use concerns can be resolved, thermal water could supply a portion of the energy requirements for space heating and industrial processing in the Mt. Hood - Portland area. End uses could include small scale district heating systems in the communities along Highway 26, industrial processing for pulp and paper mills in the east Portland area, and larger district heating systems for residential and commercial areas in Portland. 
Food processing operations in Parkdale and Odell in the Hood River Valley are potential end users if a suitable resource is located on the east side of Mit. Hood that economically can be delivered to the site. Representative energy consumption figures for a food processing plant in Hood River and a paper mill in Oregon City are shown in Appendix B.

The Mt. Hood KGRA is within a designated Wilderness Area and is, therefore, unavailable for geothermal development under Forest Service regulations. If development is allowed to take place it will occur outside the boundaries of the KGRA.

Further restrictions are possible as a result of the current RARE II process being conducted by the Forest Service. In fact, 182,355 acres in the vicinity of Mt. Hood, are being evaluated for possible inclusion into the National Wilderness Preservation System.

Most of the Mt. Hood orea has been designated by the Oregon Energy Facility Siting Council as unsuitable for geothermal development. The Council has siting authority for geothermal power plants and for pipelines greater than six inches in diameter and five miles in length. In spite of the unsuitable classification, it is assumed that the Council would consider an application for site certification.

The public is likely to be extremely sensitive to development because Mt. Hood is a major recreation area for Willamette Valley urban areas, and has high aesthetic and historical value. Environmental considerations in general are likely to be a major controlling factor effecting geothermal development in the Mt. Hood area. 
SITE DATA SUMMARY

SITE: MT. HOOD KGRA

..Physical Reservoir Data

.. Temperature ${ }^{\circ} \mathrm{C}$

estimated

Surface: $90^{\circ} \mathrm{C}$

Subsurface: $125^{\circ} \mathrm{C}$

..Total Dissolved Solids (PPM): 800 (Swim Warm Springs)

..Type of Overlaying Rock: Lava (Quaternary)

...Estimated Depth to Top of Reservoir (meters): 1,000

..Site Land Status: 14 square miles of National Forest land on Mt. Hood designated KGRA.

Total KGRA Acres - 8,671 (Federal)

Total KGRA Acres Leased - 0 (Federal)

-.Geothermal Development Status:

Exploration at Mt. Hood has been active and represents the largest geothermal research effort to date in Oregon.

..Local and State Attitude Toward Geothermal Development:

Extremely sensitive.

- Land Use and Population:

Open high mountains, forest and woodlands used primarily for timber production, recreation and agriculture. The Mt. Hood area is sparsely populated but over a million people live within a 1-2 hour drive of the area.

.. Comments and Critical Issues:

Much of the area is included or is being studied for inclusion into roadless or wilderness classification.

The public is likely to be sensitive to geothermal development. 
SITE LOCATION AND PHYSICAL DESCRIPTION

SITE: MT. HOOD KGRA

.. Latitude: $45^{\circ} 22^{\prime} 5^{\prime \prime} \mathrm{N}$

... Longitude: $121^{\circ} 42^{\prime} 5^{\prime \prime} \mathrm{W}$

..Rectilinear: T.2S., R.9E, secs. 16-22, 27-33, Willamette Meridian (W.M.)

..County: Clackamas and Hood River Counties

..Adjacent Counties: Wasco and Multnomah, Oregon; Skamania and Klickitat, Washington

.Maps: U.S.G.S. Topographic Cathedral Ridge 1:24,000, Timberline Lodge $1: 24,000$

. Topography

The Mt. Hood geothermal area lies within the Cascade Mountain Range at the crest of the High Cascade region in northern Oregon. Elevations range from 3,427 meters $(11,235 \mathrm{ft}$.) on $\mathrm{Mt}$. Hood, the highest peak in Oregon, to 243 meters $(800 \mathrm{ft}$.) on the mountain's slopes. Active glaciers and associated erosional features are present on the upper mountain slopes. Waterfalls and extensive mud flows are common.

..Present Land Use:

Land use in the Mt. Hood KGRA and vicinity is focused on the area's natural resources: timber pronduction, recreation and agriculture. Other land uses such as transportation networks, and commercial and residential developments are based on the three primary uses.

..Future Land Use Plans:

The Mt. Hood National Forest proposed plan stresses improved efficiency of land use by concentrating developments to areas that are already committed to that use, providing needed support services, increasing agricultural activities, timber production, opportunities for recreation, and maintaining the overall mountain area character.

Expansion of Timberline Lodge facilities is planned. 
..Aesthetics: High aesthetic value.

..Historical/Archaeological Significance:

Mt. Hood has been proposed for recognition to the National

Register of Natural Landmarks. Timberline Lodge and Cloud Cap

Inn are National Register Sites. Barlow Road traverses the area outside the KGRA and is classified as a segment of the Oregon Trail Route and the National Historic Trail System. Numerous known cultural resource sites are adjacent to the KGRA. 


\title{
GEOLOGICAL/GEOPHYSICAL DESCR IPTION
}

\author{
SITE: MT. HOOD KGRA
}

..Geologic Description:

The complex geology of the area reflects the volcanic history and glaciation of Mt. Hood and recent stream deposition.

Regional uplift, structural deformation and erosion by stream and ice action has accompanied the accumulation of volcanic material, flank sediments and alluvium since the Miocene age. Highly varied and discontinuous rock types have resulted from these processes.

Mt. Hood is an andesitic stratovolcano of Pleistocene age. The composite cone consists of olivine andesite, pyroxene andesite, and hornblende dacite flows and pyroclastic debris with an estimated volume of 45 cubic miles (approximately 70 percent is lava flows). A significant quantity of material has been added as a result of andesite flows and the intrusion of a plug dome since the end of glaciation. Much of the surface geology has been mapped as Pleistocene Mt. Hood clastic debris, primarily pyroclastic, but with considerable post-giacial transported detritus on the surface. (4) (10) (12)

Columbia River Basalt of mid to late Miocene age are the oldest exposed rocks. Outcrops are distributed in an area surrounding Mt. Hood which suggests that Columbia River Basalt underlies the volcano.

The Rhododendron Formation, consisting of volcaniclastic debris and interbedded andesite flows, unconformably overlies the Columbia River Basalt.

Contemporaneous with the Rhododendron Formation is the Dalles Formation. Of mid Pliocene age, the formation is made up of volcanic debris with some interbedded lava flows.

Andesites of early Pliocene age rest conformably on the Rhododendron Formation. Above these units are found: Mt. Hood volcancics, glacial and mudflow deposits, gravels, alluvium, and intrusives. $(9)(10)(11)$

A stratigraphic description of the Mt. Hood area is available in Wise (1968 and 1969). (9)

Major deformation by folding and faulting of rock units is lacking in the Mt. Hood area. 
..Geophysical Summary:

As part of the 3 year project to assess the geothermal resource of Mt. Hood, the following studies were made in 1977:

Aeromagnetics (David L. Williams), self-potential (Don B. Hoover), microseismic (H. M. Iyer and Craig S. Weaver) and infrared (Watson, Friedman and Williams U.S.G.S.).

Magnetotelluric and telluric electrical resistivity survey were done by Lawrence Berkeley Lab, Norman Goldstein and associates and Univ. of California. Marvin Beeson of Portland State University is studying Columbia River Basalt in the Mt. Hood area, and David Blackwell of Southern Methodist University is doing thermal modeling.

Craig White of University of Oregon has conducted geological and geochemical studies of young volcanic rocks and Don Hull of Department of Geology and Mineral Industries examined areas of hydrothermal alteration. Water chemistry was studied by Harold A. Wollenberg, LBL and others. (13)

References to geophysical surveys:

Couch, R. W. and Baker, B., 1977, Geophysical

Investigations of the Cascade Range in Central Oregon:

Final Reports to U.S.G.S.

Friedman, J. D., and Frank, D., 1977, Structural and Heat-flow Implications of Infrared Anomalies at Mt. Hood, Oregon: U.S.G.S. Open-File Report 77-599.

U.S.G.S., 1977, Aeromagnetic Map of Mt. Hood and Vicinity, Oregon: Open-File Report 77-819.

..Geologic tiazards:

Mt. Hood has a history of volcanic and seismic activity. The most recent recorded eruption occurred less than 300 years ago. Seismic occurrances have been recorded in 1974 at Government Camp, in 1976 on the northeast or south side of the mountain, and reportedly in mid 1978.

Other potential hazards include lands 1 ides, avalanches, erosion, high water table, flooding, and compressible soils. 


\section{RESERVOIR CHARACTERISTICS}

SITE: MT. HOOD KGRA

..Reservoir Temperature

..Surface: $90^{\circ} \mathrm{C}$

.Subsurface: $125^{\circ} \mathrm{C}$

..Geochemical

Na-K-Ca: $160^{\circ} \mathrm{C}$ estimated minimum - Swim Warm Springs

..Flow Rates: $25 \mathrm{gpm}$ at $270^{\circ} \mathrm{C}\left(80^{\circ} \mathrm{F}\right)$ at Swim Warm Springs

..pH: 7.3 (Swim Warm Springs)

..Total Dissolved Solids: 800 (Swim Warm Springs)

..Fluid Chemistry:

Boran
Calcium
Chloride
Magnesium
Manganese
Potassium
Silica
Sodium
Sulfate
Temperature
ph

Swim Warm Springs* 0.15

Fumaroles

$\begin{array}{ccc}64 & 13 \\ 170 & \text { (units } \mathrm{mg} / \mathrm{l}) & 1 \\ 51 & 2.8 \\ 0.05 & & \\ 12 & 0.2 \\ 92 & 19 \\ 120 & 5.4 \\ 240 & 77 \\ 270^{\circ} \mathrm{C} & 90^{\circ} \mathrm{C} \\ 7.3 & 3.8\end{array}$

(4)

Gas analyses of the fumaroles northeast of Crater Rock average:

1.2 percent $\mathrm{CO}^{2}, 98.7$ percent $\mathrm{H}^{2} \mathrm{O}, 0.03$ percent $\mathrm{H}^{2} \mathrm{~S}$ and 0.003 percent $\mathrm{H}^{2}$.

..Estimated Heat Content: $.3 \times 10^{18}$ cal.

U.S.G.S. estimates 24 MWe with possibility of up to 100 MWe. U.S. Dept. of Energy/Division of Geothermal Energy postulates non-electric utilization of 100 MWe.

..Subsurface Area of Reservoir: Estimated $2 \mathrm{~km}^{2}$

* Swim Warm Springs is the only hot spring in the Mt. Hood area. The springs flow at $25 \mathrm{gpm}$ at a temperature of $27^{\circ} \mathrm{C}\left(80^{\circ} \mathrm{F}\right)$ in Section 24, T.3S., R. $8 \frac{1}{2} E$. 


\section{LAND OWNERSHIP AND LEASING}

SITE: MT. HOOD KGRA

..Land Ownership - Forest Service: 8,671 TOTAL AREA (Acres)

8,671 FEDERAL (Acres)

.. Land Leased: 0

..Tentative Lease Sale Dates: No lease date scheduled.

.. Summary of Leasing Status and Needs:

The Mt. Hood KGRA is within a designated Wilderness Area and therefore, under Forest Service regulations, is unavailable for development.

The first geothermal lease on U.S. Forest Service land was issued on September 1, 1977 to R.L.K. \& Co., operator of Timber line Lodge.

The following non-competitive (outside the KGRA) have since been issued:

\section{Lessee}

Northwest Natural Gas (NWNG)

NWNG

NWNG

Max Mill is

Max Millis

Portland General Electric (PGE)

PGE

PGE

PGE
Acreage

2,560

2,560

2,560

2,550

2,604

2,560

2,520

1,901

$\frac{1,924}{21,749}$

\section{Township \& Range}

2S/8E W.M.

2S/8E H.M.

2S/8E W.M.

2S/8E W.M.

2S/8E W.M.

2S/9E W.M.

2S/10E W.M.

2S/10E W.M. 2S/10E W.M. 3S/10E W.M.

TOTAL 
GEOTHERMAL DEVELOPMENT STATUS

SITE: MT. HOOD

\section{..Present Development Status:}

A three year detailed geothermal resource assessment of Mt. Hood was undertaken in 1977 as a joint effort involving the U.S. Geological Survey, U.S. Dept. of Energy, U.S. Forest Service and the Oregon Department of Geology.

In 1977 geophysical surveys and shallow temperature gradient drilling were begun. Deeper drilling and continued geophysical studies have continued in 1978. Expenditures are expected to total almost to a million dollars, which represents the largest geothermal research project to date in Oregon.

In 1976 and 1977 a shallow gradient hole was drilled east of Timberline Lodge. Serious drilling problems were encountered. The bottom hole temperature of the 150 meter deep well near the lodge was $10.2^{\circ} \mathrm{C}$ one hour after drilling ceased.

Drilling began in August 1978 on a second test hole located near the maintenance shed at the lodge. The well has been permited to a depth of 610 meters $(2,000 \mathrm{ft}$.). In early October 1978 drilling had reached below 335 meters and was continuing. This test hole has encountered considerable drilling difficulties, particularly in cementing off cold water flow.

At 01d Maid Flat, on the west side of Mt. Hood, the Northwest Natural Gas Company (NWNG) drilled a gradient hole to 564 meters $(1,850 \mathrm{ft}$.) depth in 1977. This well was incorporated into the federal-state resource assessment program and was deepened to 1,220 meters $(4,003 \mathrm{ft}$ ) during July and Aligust 1978. Electric neutron density and fracture logs were done in August. A temperature probe indicated a bottom hole temperature of $80^{\circ} \mathrm{C}$ $\left(176^{\circ} \mathrm{F}\right)$. This reading is subject to change since the well had not reached equilibrium. Another temperature probe will be completed before the end of 1978. (14)(15)(16). 
..Projected or Planned Development:

Drilling at Timberline Lodge is expected to continue to a depth of 610 meters $(2,000 \mathrm{ft}$.). Wy' East Exploration \& Development Company is carrying out the program under the R.L.K. \& Co. geothermal lease. If suitable resources are located, the proposed plan is to supply space heating to Timberline Lodge* and the anticipated facilities expansion, and for snow melting on roads and parking lots at the lodge.

As part of the resource assessment program, eleven 152 meters (500 ft.) gradient holes have been permitted for drilling around the base of Mt. Hood. This drilling program should begin in October 1978.

Results of the deep drilling at 01d Maid Flat will continue to be evaluated to examine the feasibility of Northwest Natural Gas Company's proposed heating project. The objective is to locate a sufficient resource to justify a 48 inch pipeline over a $69 \mathrm{~km}$ (43 mile) distance to Portland for industrial processing and space heating. If resource capabilities are proven, it is likely that federal funds will be sought for a demonstration project.

*Timberline Lodge, which uses approximately 38,000 gallons of oil per month, is the largest single-building consumer of heating oil in Oregon. 


\section{INSTITUTIONAL CONSIDERATIONS}

SITE: MT. HOOD

.. Institutional Requirements:

Oregon Law (ORS 469.300) requires a geothermal power plant or a pipeline greater than six inches in diameter and 5 miles or longer in length to be certified by the Energy Facility Siting Council.

Areas defined by the Council as "Natural Resource Areas" have been designated as unsuitable for geothermal development.

Exploration activities in the 01d Maid Flat area border or are in areas designated as unsuitable.

In March 1978 legislation was passed which will include the entire (with the possible exception of two sections) Mt. Hood KGRA in Wilderness classification.

The Bull Run Reserve (watershed for Portland) was reopened in mid 1978 after being closed for several years. It is unlikely that any geothermal development which impacts the watershed will be permitted.

..Agency and Public Attitudes:

The public is likely to be extremely sensitive to geothermal development because Mt. Hood is a major recreation area for the population centers in the Willamette Valley, and has high aesthetic and historical value.

In June 1978, public involvement sessions were heid to solicit input to goals established by the Forest Service for the Clackamas Planning Unit. Of the 70 responses to the goal for providing opportunity for energy development, 27 percent felt that it was very important, 30 percent-important, 20 percent-desirable and 23 percent undesirable.

The goal was revised to state, "Provide opportunity for energy development. Energy development will minimize environmental impacts and conflicts with other uses or damage to surface resources". A significant percentage of the public in attendance expressed that geothermal development is incompatible with other values. (17) 
..Status of Requirements (i.e., EIA/EIS Requirements)

Draft EAR for proposed leasing of geothermal resources with non-surface occupancy restrictions-completed by Mt. Hood National Forest in 1977.

Final Environmental Statement for Mt. Hood Planning Unit Interagency Land Use Plan - completed 10/77. This EIS addresses geothermal development only in general terms.

The second land use planning unit encompassing the Mt. Hood Geothermal area is for Clackamas, south of Mt. Hood. The draft land management plan for the Clackamas unit is scheduled for release in March 1979.

A large portion of the Mt. Hood geothermal area is being evaluated for possible allocation to roadless lands through the U.S. Forest Service Roadless Area Review and Evaluation (RARE II) process. After examining the areas and soliciting public comment the Forest Service will make one of the following determinations: recommend for inclusion in the National Wilderness Preservation System, recommend for further study, return to multiple-use designation.

As classified by the Forest Service in the Oregon Supplement to the Draft Environmental Statement RARE II, none of the areas under study have producing, proven or possible geothermal resources. This, despite the fact that the KGRA is included in one of the study areas. The areas in question include the following:

\begin{tabular}{|c|c|c|c|c|}
\hline Area & $\begin{array}{l}\text { Area } \\
\text { Conde }\end{array}$ & $\begin{array}{l}\text { Administrative District } \\
\text { Mt. Hood National Forest }\end{array}$ & $\begin{array}{l}\text { Total } \\
\text { Acreage }\end{array}$ & $\begin{array}{l}\text { Forest Service } \\
\text { Ownership Acres } \\
\end{array}$ \\
\hline Eagle & 090 & $\begin{array}{l}\text { Columbia Gorge P.anger } \\
\text { District }\end{array}$ & 41,200 & 4,052 \\
\hline Lake & 091 & $\begin{array}{l}\text { Columbia Gorge \& Hood } \\
\text { River Districts }\end{array}$ & 10,900 & 10,874 \\
\hline Big Bend & 092 & Columbia Gorge District & 11,000 & 11,000 \\
\hline Mt. Hood Additions & 093 & $\begin{array}{l}\text { Hood River \& Zigzag } \\
\text { Districts }\end{array}$ & 11,600 & 11,470 \\
\hline Wind Creek & 094 & Zigzag District & 6,088 & 6,088 \\
\hline Salmon-Huck leberry & 095 & $\begin{array}{l}\text { Bear Springs, Estacada } \\
\text { \& Zigzag Districts }\end{array}$ & 68,800 & 68,330 \\
\hline Twin Lakes & 096 & Bear Springs District & 5,385 & 5,385 \\
\hline Badger Creek & 097 & Bar low Ranger District & 27,382 & 27,302 \\
\hline
\end{tabular}


ENVIRONMENTAL FACTORS

SITE: MT. HOOD

\section{. CLIMATE}

..Prevailing Winds:

West (Dry east winds occur during September and October)

..Precipitation (Annual):

Precipitation varies greatly with elevation and occurs primarily during the winter months, mainly as snow above the 1,067 meter elevation. Ranges from approx. $165 \mathrm{~cm}$. at $305 \mathrm{~m}$. to $356-432 \mathrm{~cm}$. at 1,219-1,524 meters.

. Average Temperature

Minimum: -7 to $-1^{\circ} \mathrm{C}\left(20-30^{\circ} \mathrm{F}\right)$

Maximum: 10 to $16^{\circ} \mathrm{C}\left(50-60^{\circ} \mathrm{F}\right)$

..Degree Days (Annual):

7,949 (Estacada) Number of degree days would be much higher in the Mt. Hood area.

..Relative Humidity (Seasonal Peaks)

Summer: $\quad 50-60$ percent

Winter: $79-80$ percent

..AIR QUALITY:

Air quality is believed to be relatively high in the Mt. Hood area, although actual characteristics are not known since no measuring stations are maintained. Generally there is good air dispersion on the upper slopes of the mountain due to nearly constant winds. Proximity to the Portland metropolitan area does affect air quality but the extent of the influence is not known. (2) 
The major sources of pollution are dust, vehicle emissions and smoke from slash burning. In the Devil's Kitchen area near the summit of Mt. Hood the fumaroles contain up to nearly 0.2 percent $H^{2} S$, as well as sulphur precipitate. Concentrations of $H^{2} S$ at Swim Warm Springs are generally below the detection limit. (4)

The Oregon Department of Environmental Quality has special restrictions applied to air quality standards in wilderness areas.

..WATER QUALITY:

Water quality is generally very high above populated areas. Mt. Hood is a ground water recharge area.

Numerous rivers and creeks are in the area.

..NOISE:

Noise levels are extremely low except in the developed areas along Highway 26, developed recreation areas and in communities. Activities that generate higher noise levels like logging and gravel operations tend to be temporary and distant from residential areas.

. BIOLOGICAL

.Dominant Flora: Coniferous species

Below $762 \mathrm{~m}$ :

Douglas fir/western hemlock (Pseudotsuga

menziesii/Tsuga heterophy $11 \mathrm{a}$ )

Above $1,067 \mathrm{~m}$ :

Pacific silver fir (Abies amabilis) and nuble fir (Abies lasiocarpa)

Higher Elevations:

Mountain hemlock (Tsuga mertensiana) and subalpine fir (Abies lasiocarpa)

Forest becomes discontinuous above $1,524 \mathrm{~m}$. and timberl ine averages $1,981 \mathrm{~m}$. in elevation.

. Dominant Fauna:

Wildl ife habitats and species are greatly diversified given the varied geography of the Mt. Hood area.

A wildl ife species list is included in the Mt. Hood Planning Unit Environmental Statement. 
... Endangered Species

Flora: Pityopus californicus

Polystichum Kruckebergi

Plants being considered for adoption as Rare, Endangered, or Threatened by the Oregon Rare and Endangered Plant Species Task Force.

Arabis furcata

Arenaria purnicola

Betula glandulosa var. glandulosa

Calamagrost is breweri

Calypso bulbosa

Cimicafuga lacíniata

Collomia debilis var. larsenii

Cypripedium montanum

Draba aureola

Eburophyton austiniae

Eriogonum umbellatum var. hausknechtii

Habenaria orbiculata

Hemitomes congestum

Hulsea nana

Hypopitys monotropa

Isopryum hallij

Lilium washingtonianum

Lycopodium camplanatum

L. inundatum

Parnassia fimbriata var. hoodiana

Penstemon euglaucus

P. peckii

$P_{0}$ subserratus

Phlox hendersoni i

Pityopus californica *

PTeurocospora fimbriolata

Poa suksdorfii

Polystichum andersonii

P. kruckebergii *

P. Tonchitis

Potentilla villosa

Ribes watsoniana

Sedum divergens

Silene suksdorfii

Smelowskia ovalis

Thelypteris nevadensis

*Also listed by the Smithsonian Institution as Endangered or Threatened.

(2) 
Fauna: American Peregrin Falcon (Falco peregrinus anatum)

Oregon State Threatened Classification:

Northern bald eagle (Haliaeetus leucocephalus alascanus)

Northern spotted owl (Strix occidental is caurina) Wolverine (Gulo luscus)

Western Spotted Frog (Rana pretiosa) 
TRANSPORTATION AND UTILITIES

SITE: MT. HOOD

..Utility or Energy Transmission Corridors and Facilities

Bonneville Power Administration (BPA) owns four transmission lines which carry power generated from the Columbia River hydroelectric sites west into Portland. There is one $230 \mathrm{KV}$ line, one $500 \mathrm{KV}$ line, one $287 \mathrm{KV}$ capacity line operating at 230 $K V$, and one $345 \mathrm{KV}$ line operating at $230 \mathrm{KV}$.

There are numerous other transmission lines in the Mt. Hood-Portland area owned by the Portland General Electric Company (private) and the Pacific Power and Light Company (private).

A major gas line $30 \mathrm{~cm}$ ( 24 inches) is within $16 \mathrm{~km}$ (10 miles) of the area.

..Transportation Corridors or Facilities

U.S. Route 26 - the most direct route between Portland and the Mt. Hood recreation areas.

Oregon Highway 35 - runs east and northward to complete the Mt. Hood Loop to the Hood River community. Highway 35 connects to Interstate 80 at Hood River.

Secondary roads include: Timberline Road, Bennett Pass Road, Cloud Cap Road, West Leg Road, Still Creek Road, Truman Roäd, Lclo Pass Road.

There are numerous Forest Service and logging roads in the vicinity. Primary railroad is located $16 \mathrm{~km}$ (10 miles) from the area. 
POPULATION

SITE: MT. HOOD, OREGON

\section{..General Description of Population}

Population of the Mt. Hood area (Mt. Hood National Forest Planning Unit) was estimated to be between 7,060 and 7,160 in 1975. Seasonal residents comprise approximately 57 percent of the total with the remaining 43 percent as permanent. residences. Population increased between 1970 and 1975 and is expected to double or triple in the next 20 years.

The heavy seasonal flucuations in population corresponding to seasonal recreation and employment patterns double population densities during certain times of the year.

Most of the population is concentrated along Highways 26 and 35. Areas available for development already have densities approaching urban or suburban areas. This pattern is likely to continue to increase since only a small percentage of land is in private ownership.

Proximity to Portland and other population centers of the Willamette Valley draws many people into the Mt. Hood area for recreational purposes.

\section{Population Centers}

Government Camp

Parkdale

Cheiryville and Alder Creek

Brightwood to Sleepy Hollow

zigzag

Rhododendron

Wi ldwood, Welches and Wemme
Population

$550(3 / 4$ seasonal $)$

$300+$ seasonal migrants $(300)$

520 (few seasonal)

1000-1100 (seasonal \& permanent)

750 (seasonal \& permanent)

320 (high precent seasonal)

1600 (40-50 percent seasona 1$)$ 
.. Economics

Present Land Use:

Primarily National Forest.

Recreation and tourism, including three major resort establishments.

Timber management contributes significantly to the local and regional economy.

Employment in logging operations in the Mt. Hood vicinity is seasonal, generally six to nine months.

Agricultural operations are located northeast of Mt. Hood in the upper Hood River Val ley and consist primarily of apple and pear orchards. The fruit is processed in Parkdale and 0dell and marketed regionally and nationally.

Small retail and commercial sectors are developed in the $\mathrm{Mt}$. Hood communities and along the highways to provide services.

..Future Land Use:

The Mt. Hood National Forest proposed plan stresses improved efficiency of land use by concentrating development in areas already committed to that use, providing adequate support services, increasing agricultural and timber productivity and recreational opportunities, and maintaining the overall mountain area character.

(2) 


\section{Western Cascades}

To the west of the High Cascades is the older, more deeply dissected mountainous belt known as the Western Cascades. The area has been described as a sloping plateau that is so throughly dissected that little of the original plateau surface is evident. The predominate pattern is one of valleys and ridges with the greatest amount of local relief in the areas of the major streams.

Unlike the young volcanics of the High Cascades, the Western Cascades rock units generally show the effects of folding and faulting. The major hot springs of the Western Cascades are aligned in a relatively narrow zone nearly parallel to the axis of the range. Baldwin (1964) has suggested that a north trending fault controls the alignment of these springs. This series of hot springs all flow from structurally deformed volcanic strata of the Tertiary Western Cascade Group and generally run along the $122^{\circ}$ West meridian. Each of the hot springs areas have been classifed by the U.S. Geological Survey as a Known Geothermal Resource Area. As discussed in the following subchapters, the major thermal springs are, from north to south; Carey, Breitenbush, Belknap; Foley and McCredie. 


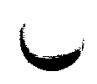

$$
268
$$


SITE: CAREY HOT SPRINGS KGRA

(Austin Hot Springs)

Oregon 


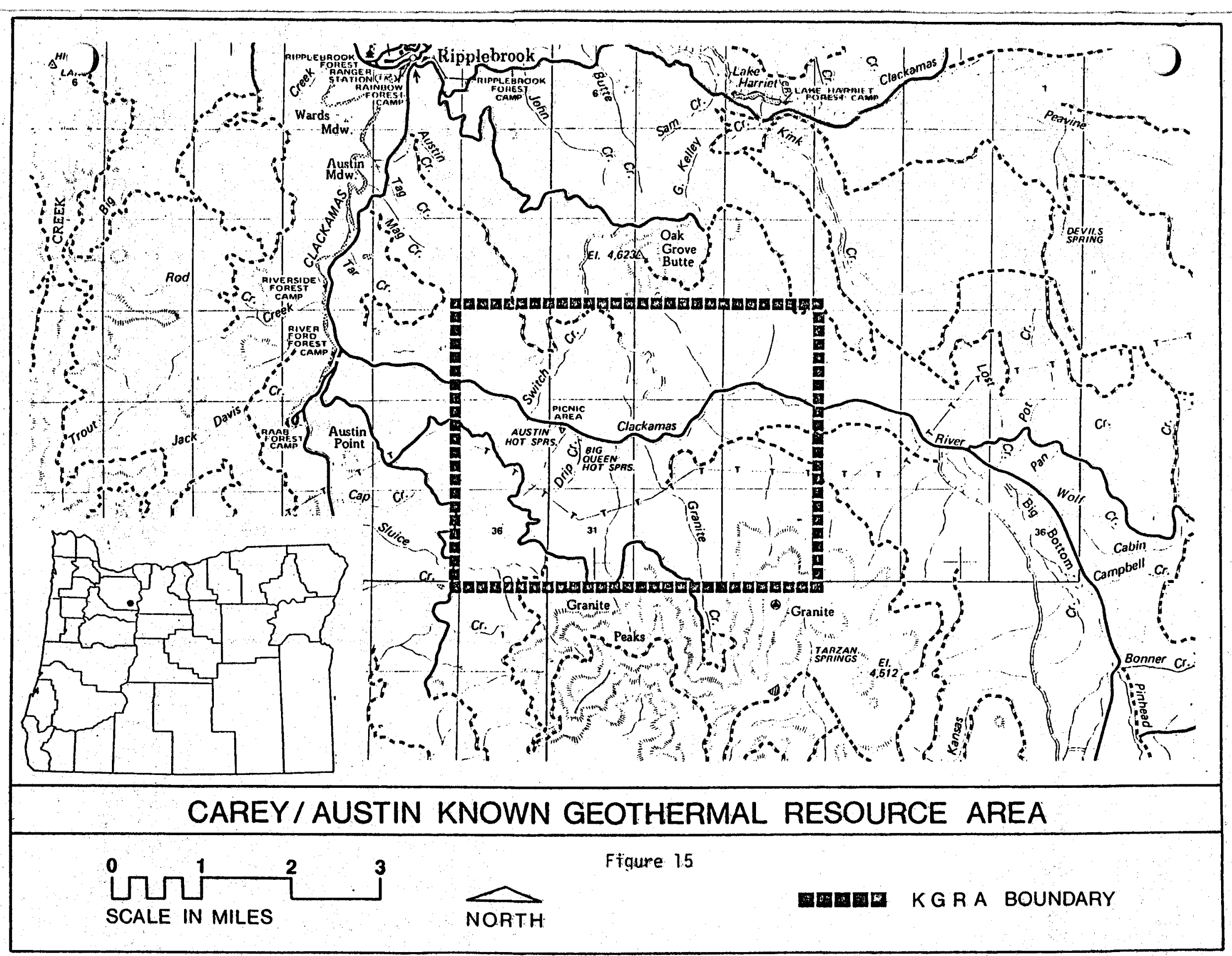




\section{CAREY HOT SPRINGS KGRA}

The Carey Hot Springs KGRA is located in T.6S., R.7E., W.M., in Clackamas County, Oregon. The area is locally known and shown on Forest Service maps as Austin Hot Springs. The logging and recreational oriented community of Estacada with a population of 1,620 is about $40 \mathrm{~km}$ (25 miles) northwest of the hot springs.

The topography of the KGRA is typical of the Western Cascades - rugged forested land with steep slopes and well developed river valleys. Elevation at the hot springs is 520 meters $(1,706 \mathrm{ft}$.$) . The springs discharge into the$ Clackamas River which is a tributary of the Willamette River.

The KGRA covers 7,419 acres of which all but 160 acres is in federal ownership. Public land is managed as part of the Mt. Hood National Forest. Private land is owned by the Portland General Electric Company (PGE) which maintains a public recreation site for picnicking and swimming ot the hot springs. PGE also owns a transmission line which runs east to west one mile south of the hot springs on Forest Service land. Another PGE transmission line begins at the Three Lynx power station about $22 \mathrm{~km}$ north-northwest of the KGRA and travels east.

Completely surrounding the Corey Hot Springs KGRA is National Forest land used intensively for timber production and recreation. Population levels are low. A few persons are housed at the Forest Service Ripplebrook Ranger Station about $10 \mathrm{~km}$ from the hot springs and several PGE employees reside at Three Lynx and maintain the small power station on the Clackamas River. The nearest sizeable community is Estacada. It is primarily a logging town which also provides services to recreationist and is the site of a Forest Service district office.

Future land use plans for tederally owned land including the KGRA are now being developed by the Mt. Hood National Forest. The plan will likely stress increased timber production, recreational opportunities and roadless areas.

Geothermal potential is expressed at Carey Hot Springs which flow from about a dozen orifices adjacent to the Clackamas River. Both the location and the alignment of the springs appears to be fault controlled (Hammond 1976). The springs discharge 950 liters per minute (lpm) of $86^{\circ} \mathrm{C}$ water. Silica geothermometry indicates that temperatures as high as $124^{\circ} \mathrm{C}$ may be encountered at depth. 
Development interest has been expressed by the filing of lease applications in areas around the KGRA and the drilling of a gradient hole by Sunoco Energy Co. The company drilled a 457 meter $(1,500 \mathrm{ft}$.) well as a temperature monitor hole about $2.4 \mathrm{~km}$ east of Carey Hot Springs. Drilling and temperature data has not been released.

Two test wells near Carey Hot Springs have also been drilled by the Oregon Department of Geology and Mineral Industries. The average gradients between 15 and 150 meters were $297^{\circ} \mathrm{C} / \mathrm{km}$ and $81^{\circ} \mathrm{C} / \mathrm{km}$.

The range of potential geothermal applications based on the estimated subsurface temperature of $125^{\circ} \mathrm{C}$ includes: space heating, aquaculture, greenhouses, de-icing, drying of organic materials, commercial processing and kiln drying of lumber. Implementation of such uses is hampered by the lack of resource certainty and by the limited population of the area.

The closest concentration of energy consumers is in Estacoda about 40 $\mathrm{km}$ away. Although the town may be too small to economically justify a heating district on its own, a large industrial user such as the Crown Zellerbach mill could possibly improve the chances of piping hot water from the Carey Hot Springs area. Deep exploration is necessary to prove the capabilities of the resource. However, exploration is not likely to begin until land positions have been established.

Competitive leasing will not take place and non-competitive lease applications cannot be processed until an environmental statement covering the Carey Hot Springs area has been completed by the Forest Service. The Clackamas Unit Land Management Plan is now being developed with a draft scheduled for release in March 1979. The plan will provide criteria and guidelines for leasing decisions but action cannot be taken until the plan becomes final.

The RARE II process now underway has included 78,208 acres of the Bull of the Woods and Olallie Lakes areas in the vicinity of the KGP.A as potential sites for roadless or wilderness classification. Geothermal development would not be permitted in areas so designated.

Environmental concerns in general, as expressed by the public and government agencies, are likely to be a major factor in controlling geothermal development not only at Carey Hot Springs, but in all areas of the Cascades. 


\section{SITE DATA SUMMARY}

SITE: CAREY HOT SPRINGS KGRA (Aust in Hot Springs)

..Physical Reservoir Date

.. Temperature ${ }^{\circ} \mathrm{C}$

Surface: $\quad 86^{\circ} \mathrm{C}\left(185^{\circ} \mathrm{F}\right)$

Subsurface: $\quad 125^{\circ} \mathrm{C}\left(257^{\circ} \mathrm{F}\right)$

..Type of Overlaying Rock: 01 ivine basalt, basaltic andesite, pyroxene andesite

..Estimated Depth to Top of Reservoir (meters): 1,500

.. Site Land Status - Most of the land is in Mt. Hood National Forest ownership.

Total Acres - KGRA

Total Acres Leased

7,419 (Federal)

None (Federal)

..Geothermal Development Status:

Two temperature gradient holes have been drilled by the Oregon Department of Geology and Mineral Industries.

Sunoco Energy Company drilled a 457 meter $(1,500 \mathrm{ft}$.$) gradient$ hole.

- Local and State Attitude Toward Geothermal Development:

Extremely sensitive.

. Land Use and Population:

Few permanent residents.

Primarily National Forest land. Timber production and roaded recreation.

..Comments and Critical Issues:

Leasing decisions cannot take place until the land management plan has been completed by the Forest Service. The draft plan is due in March 1979. 
SITE LOCATION AND PHYSICAL DESCRIPTION

SITE: CAREY HOT SPRINGS KGRA

..Latitude: $\quad 45^{\circ} 011^{\prime} 2$ : N

..Longitude: $122^{\circ} 0^{\prime} 6^{\prime \prime} \mathrm{W}$

..Rectilinear: T.6S., R.6E., Secs. 24, 25, 36; T.6S., R.7E., Secs. $19-21,28-33$, W.M.

... County: Clackamas

..Adjacent Counties: Marion, Yamhi11, Washington, Multnomah, Hood River, Wasco

..Maps: Fish Creek Mountain - 1:62,500, Vancouver - 1:250,000

..Topography

Rugged forested land in the Western Cascades. Elevation at the hot springs is $520 \mathrm{~m} .(1,706 \mathrm{ft}$.$) . The springs are located in$ the Clackamas River bottom and surrounded by steep slopes.

..Present Land Use:

The public land is maintained by the U.S. Forest Service for timber management and recreational purposes. Adjacent to the hot springs, Portland General Electric owns 160 acres which are established as a developed recreation site.

. Future Land Use Plans:

Land use goals and plans are being developed for the area in federal ownership by the Mt. Hood National Forest. A draft plan is due in March 1979 and will likely stress timber production, recreation and roadless areas.

..Aesthetics:

The forested character of this Western Cascade region contributes to the overall high scenic value.

..Historical/Archaeological Significance: Unknown 


\section{GEOLOGICAL/GEOPHYSICAL DESCRIPTION}

\section{SITE: CAREY HOT SPRINGS}

..Geologic Description:

The Carey Hot Springs area was included in a geologic study of the central and northern Oregon Cascades by Peck and others (1964).

The oldest exposed unit in the hot springs area is the Nohorn Formation of mid to late Miocene age. Other rock units of the Western Cascade Group present in the area include: the Bull Creek Formation composed primarily of volcanic sedimentary rocks (mid to late Miocene); young basalts of High Cascade origin; and alluvium and landslide debris at the surface.

Cropping out along the Clackamas River near the hot springs are intrusive dikes, plugs and sills of pyroxene-bearing andesites. An exposed intrusive of highly altered andesite porphyry is located east of the hot springs. This intrusive may be part of the Austin Point pluton which is a pyroxene andesite intrusion located at the confluence of the Collawash and Clackamas Rivers. (12) (20) (10)

Hammond (1976) has mapped a west-northwest $14 \mathrm{~km}$ long fault with approximately 122 meters of displacement from near Granite Peaks through the hot springs to the North Fork of the Clackamas River. This fault appears to control the location of Carey Hot Springs and alignment of the spring orifices. Hammond suggests that the fault is part of a wide belt of north-northwest trending faults which are a possible extension of the Brothers Fault Zone through the Cascades. (21)

..Geophysical Summary:

Three temperature gradient wells have been drilled in the vicinity. 
..Mineral Occurrences:

Mercury has been mined in the past along the upper Clackamas River. (20)

..Geologic Hazards:

Slopes and canyons of weathered volcanic debris, and interbedded ash and sedimentary rocks have potential landslide problems.

Seismic intensity levels are relatively low when compared to many other areas in Oregon. 


\section{RESERVOIR CHARACTERISTICS}

\section{SITE: CAREY HOT SPRINGS KGRA}

..Reservoir Temperature

.. Surface: $\quad 86^{\circ} \mathrm{C}\left(185^{\circ} \mathrm{F}\right)$

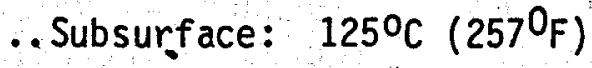

..Geochemical: (Estimated minimum)

Silica Conductive: $124^{\circ} \mathrm{C}$ Silica Adiabatic: $124^{\circ} \mathrm{C}$

$\mathrm{Na}-\mathrm{k}-1 / 2 \mathrm{Ca}$ : $118^{\circ} \mathrm{C} \mathrm{Na}-\mathrm{k}-4 / 3 \mathrm{Ca}$ :

$88^{\circ} \mathrm{C}$

..Flow Rates: $9501 \mathrm{pm}$

..pH: 7.63 (8)

..Fluid Chemistry: Suggests a hot-water-dominated hydrothermal. system.

$\begin{array}{lcc}\text { Specific Conductance (micromhos) } & 1,720 & \\ \text { Silica } & 81 & \\ \text { Calcium } & 35 & \\ \text { Magnesium } & 0.1 & \text { (Units mg/l) } \\ \text { Sodium } & 300 & \\ \text { Potassium } & 7.1 & \\ \text { Lithium } & 0.4 & \\ \text { Bicarbonate } & 56 & \\ \text { Carbonate } & 1 & \\ \text { Sulfate } & 140 & \\ \text { Chloride } & 430 & \\ \text { Flouride } & 1.4 & \\ \text { Boron } & 2.6 & \text { (8) (19) }\end{array}$

.Estimated heat content: $.1 \times 10^{18} \mathrm{cal}$.

. Subsurface Area of Reservoir: $1.5 \mathrm{~km}^{2}$ estimated

Carey Hot Springs flow at an estimated $950 \mathrm{lpm}$ from approximately 10 or ifices in Sec. 30, T.6S., R.7E., W.M., adjacent to the Clackamas River. 
LAND OWNERSHIP AND LEASING

SITE: CAREY HOT SPRINGS KGRA

..Land Ownership KGRA

TOTAL AREA

FEDERAL

PR IVATE

(Acres)

(Acres) (Acres)

7,579

7,419

160

..Land Leased

0

..Tentative Lease Sale Date: 1/1/79 (will be rescheduled for later lease date)

.. Summary of Leasing Status and Needs:

Land management plan must be completed before leasing can take place.

The draft plant is scheduled for release in March 1979.

Non-competitive lease applications should be processed by August 1979.

Non-competitive Lease Applications: Carey Hot Springs

Applicant

Alaska Pacific Lumber Co.

City of Eugene

C. Hook

Sunoco Energy Development Co.
Acreage

20,498

3,748

10,369

unknown 


\section{GEOTHERMAL DEVELOPMENT STATUS}

SITE: CAREY HOT SPRINGS KGRA

..Present Development Status:

Existing use of the hot springs for recreational bathing at a developed roadside park.

Sunoco Energy Company completed drilling a $457 \mathrm{~m} . \quad(1,500 \mathrm{ft}$. temperature gradient hole in early 1978. The drill site was

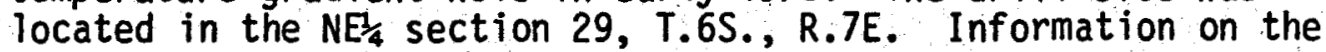
results of the drilling has not been released.

The Oregon Department of Geology and Mineral Industries drilled two gradient holes and measured geothermal gradients in several existing wells. Data from this drilling program are included in the following pages.

..Projected or Planned Development:

There are not any known plans for development.

The formulation of $\mathrm{plans}$ for further exploration and development by private entities appears to be contingent upon establishing a land position if the Forest Service al lows leasing. 
Location: T.6S., R.7E., Sec. $30 \mathrm{NW}_{4} \mathrm{NW}_{\frac{1}{4}}$, W.M.

Map Reference: AMS Vancouver, Oregon

Date Measured: 9/30/76

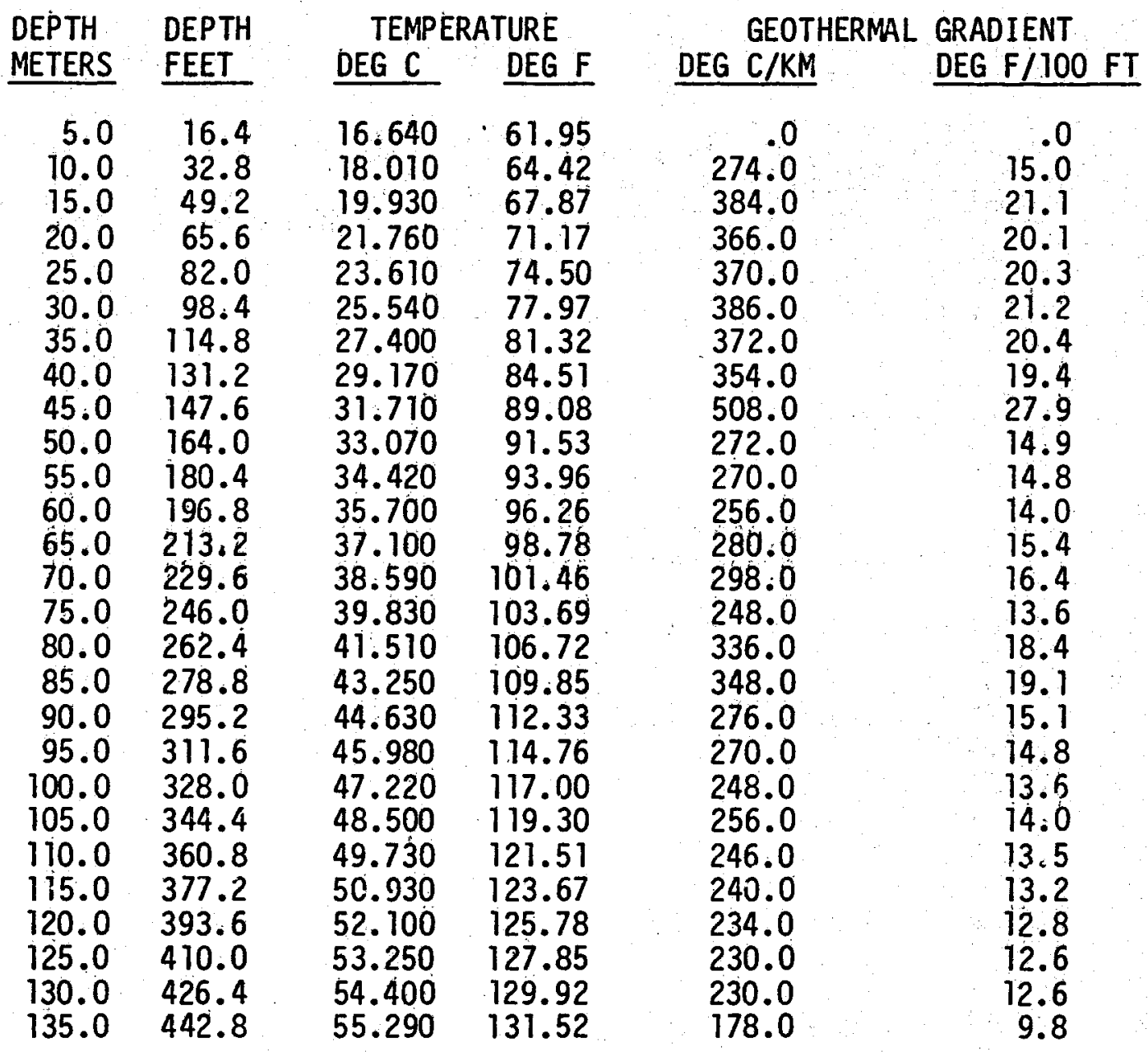

Average gradient $10-135$ meters $-297.3^{\circ} \mathrm{C} / \mathrm{km}$

(24) 


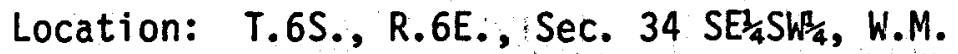

Map Reference: AMS Vancouver, Oregon

Date Measured: 9/30/76

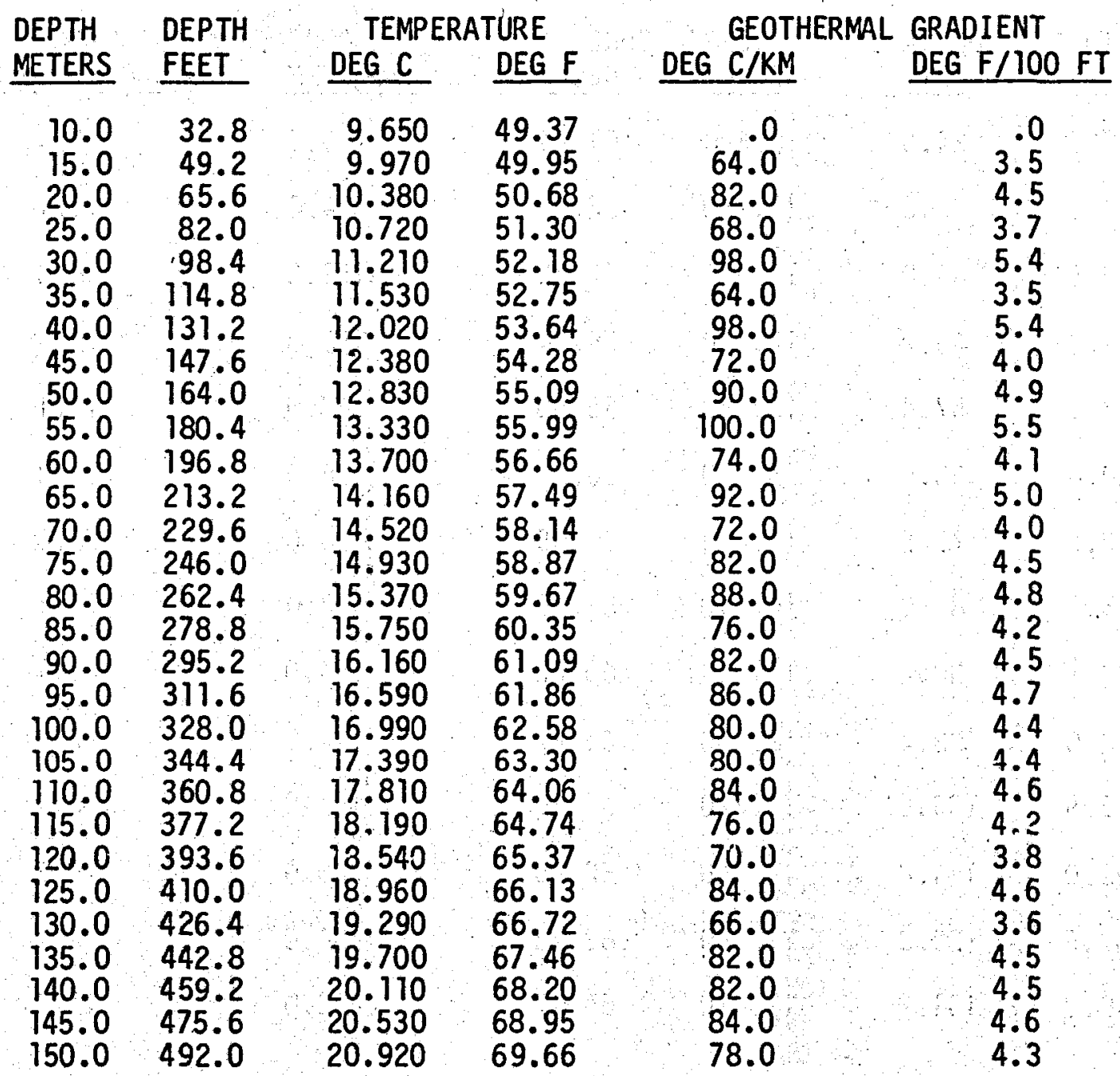

Average gradient $15-150$ meters $-80.50 \mathrm{C} / \mathrm{km}$ 
Location: T.6S., R.7E., Sec. 21 SE $\frac{1}{4} S^{\frac{1}{4}}$, W.M.

Map Reference: AMS The Dalles, Oregon

Date Measured: 6/29/77

\begin{tabular}{|c|c|c|c|c|c|}
\hline DEPTH & DEPTH & TEMPI & URE & GEOTH & GRADIENT \\
\hline METERS & FEET & DEG C & $\underline{D E G} F$ & DEG C/KM & DEG $F / 100, F T$ \\
\hline 7.5 & 24.6 & 10.690 & $51 . .24$ & 0.0 & 0.0 \\
\hline 10.0 & 32.8 & 11.150 & 52.07 & 184.0 & 10.1 \\
\hline 12.5 & 41.0 & 11.530 & 52.75 & 152.0 & 8.3 \\
\hline 15.0 & 49.2 & 12.410 & 54.34 & 352.0 & 19.3 \\
\hline 17.5 & 57.4 & 13.380 & 55.90 & 348.0 & 19.1 \\
\hline 20.0 & 65.6 & 13.770 & 56.79 & 196.0 & 10.8 \\
\hline 22.5 & 73.8 & 14.160 & 57.49 & 156.0 & 8.6 \\
\hline 25.0 & 82.0 & 14.940 & 58.89 & 312.0 & 17.1 \\
\hline 27.5 & 90.2 & 15.900 & 60.62 & 384.0 & 21.1 \\
\hline 30.0 & 98.4 & 16.360 & 61.27 & 144.0 & 7.9 \\
\hline 32.5 & 106.6 & 16.720 & 62.10 & 184.0 & 10.1 \\
\hline 35.0 & $i i 4.8$ & 17.140 & 62.85 & 168.0 & 9.2 \\
\hline 37.5 & 123.0 & 17.350 & 63.23 & 84.0 & 4.5 \\
\hline 40.0 & 131.2 & 17.870 & 64.17 & 208.0 & 11.4 \\
\hline
\end{tabular}

Average gradient $10-40$ meters $-220.9^{\circ} \mathrm{c} / \mathrm{km}$ 


\section{INSTITUTIONAL CONSIDERATIONS}

\section{SITE: CAREY HOT SPRINGS}

\section{..Institutional Requirements:}

Neither competitive or non-competitive leasing can be addressed until the Forest Service issues leasing recommendations as part of the land management plan now in progress.

RARE II land-use decisions may also effect geothermal activities in the area. The following areas are undergoing review:

Bull of the Woods

(code 6098) 69,535 acres Mt. Hood National Forest and Willamette National Forest

Olallie Lakes

(code 6099) 8,673 acres Mt. Hood National Forest. (26)(23)

..Agency and Public Attitudes:

As is the case in all Western Cascade geothermal areas, the public is likely to be sensitive to geothermal development.

A survey of public attitudes is in progress through the land management planning process. Initial inputs are as foilows:

In June 1978, public involvement sessions were held to solicit input to goals established by the Forest Service for the Clackamas Planning Unit. Of the 70 responses to the goal for providing opportunity for development, 27 percent felt that it was very important, 30 percent-important, 20 percent-desirable and 23 percent undesirable. (17)

The goal was revised to state, "Provide opportunity for energy development. Energy development will minimize environmental impacts and conflicts with other uses or damage to surface resources". A significant percentage of the local public in attendance expressed that geothermal development is incompatible with other values. 
..Status of Requirements (i.e., EIA/EIS Requirements)

The Land management plan for the Clackamas unit of the Mt. Hood National Forest was in progress during the fall of 1978. A draft plan is due in March, 1979 which will provide guidelines and criteria for leasing decisions. 


\section{ENVIRONMENTAL FACTORS}

\section{SITE: CAREY HOT SPRINGS}

..CLIMATE Marine influence

..Prevailing Winds: Varying from southwest to northwest

..Precipitation (Annual): $203 \mathrm{~cm}$.

..Days of Sunshine (Annual): 220

..Average Temperature $\quad 57.70^{\circ}$

Minimum: $38.60_{\mathrm{F}} \quad$ (Temperature \& degree day data Maximum: $65.2^{\circ} \mathrm{F} \quad$ are based on measurements for Estacada - $40 \mathrm{~km}$ northwest)

..Degree Days (Annual): 5,021

. Relative Humidity (Seasonal Peaks)

Sumer: $40-50$ percent Winter: $70-90$ percent

\section{..AIR QUALITY:}

Air quality is generally high because of the area's relative isolation from population concentrations.

Present sources of pollution include: vehicle emission, dust from unpaved roads, and smoke from slash burning and field burning in the Willamette Valley.

No measuring stations are maintained in the immediate area. (22)

\section{..WATER QUALITY:}

Surface water quality is high. There is occassional siltation of rivers and streams as a result of upstream erosion or mass wasting. (22) 
..NOISE:

Noise levels are low. Highway traffic and timber operations are the main impacts. (22)

..BIOLOGICAL

.Dominant Flora:

Douglas-fir forest.

Principal associates:

Douglasfir (Pseudotsuga menziesii)

Western hemlock (Tsuga heterophylla)

Western redcedar (Thuja plicata)

At higher elevations $(>914 \mathrm{~m})$ the True fir-Mountain hemlock forest association predominates.

..Dominant Fauna:

Black-tailed deer, Roosevelt elk, black bear, cougar, coyote, raptorial birds, beaver, songbirds and others.

.,ENDANGERED SPECIES

Flora: Plants listed by the Oregon Task Force are known in the west central Cascades and may be in the area.

Wood fern

Sword fern

Bog birch

Cranberry

Reedgrass

Washington lily

Bog orchid

Rue anemone

Matted saxifrage

Pinefoot

Tall agoseris

Alpine collomia

Crater Lake sardwort
(Thelypteris nevadensis)

(Polystichum californicum)

(Betula glandillasa)

(Vaccinium oxycoccus var. intermedium)

(Calamagrostis brewer i)

(Lilium Washingtonianum)

(Habenaria orbiculata)

(Isopyrum halliii)

(Saxifraga bronchialis var. vespertina)

(Pityopus californicus)

(Agoseris elata)

(Collomia debilis var. larsenii)

(Arenaria pumicola)

Fauna: American peregrine falcon (Falco peregrinus anatum) Arctic peregrine falcon (Falco peregrinus tundrius)

Threatened Species:

Wolverine (Gulo luscus)

Northern BaTdEagle (Haliaectus leucocephalus alasanus)

Northern Spotted Owl (Strix occidentalis caurina) 


\section{TRANSPORTATION AND UTILITIES}

SITE: CAREY HOT SPRINGS KGRA

..Utility or Energy Transmission Corridors and Facilities

Portland General Electric transmission line runs one mile south of the hot springs on U.S. Forest Service land.

Three Lynx powerhouse and transmission line is located approximately 14 air miles $\mathrm{N} / \mathrm{NW}$ of the springs area.

..Transportation Corridors or Facilities

Forest Service Highway 224

Numerous other Forest Service and logging roads. 


\section{POPULATION}

SITE: CAREY HOT SPINGS, KGRA

..General Description of Population

Population levels are low because most of the area is managed for timber production by the Forest Service. A few Forest

Service employees reside at Ripplebrook Ranger Station about 6 miles from the hot springs. The largest concentration is

Estacada, population 1,620, approximately $40 \mathrm{~km}$ northwest.

\section{...Economics}

..Present Land Use:

Economically the most important land use allocations are for timber production and recreation.

..Future Land Use:

Future land use plans are presently being developed for the Clackamas unit by the Mt. Hood National Forest. 
SITE: BREITENBUSH HOT SPRINGS, KGRA

OREGON 


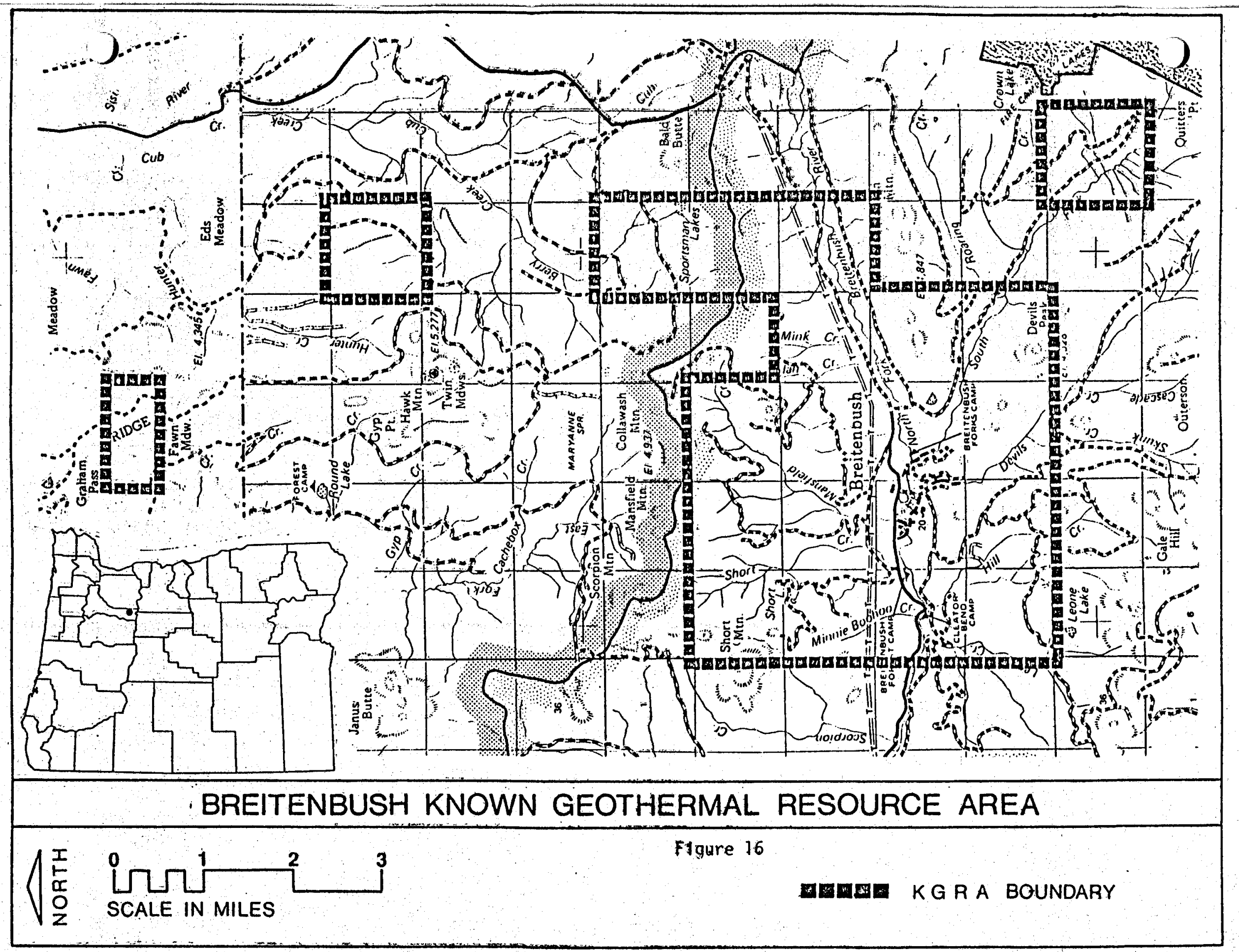




\section{BREITENBUSH HOT SPRINGS KGRA}

The Breitenbush Hot Springs Known Geothermal Resource Area covers 13,445 acres in the western region of the Oregon Cascade Range. It is located in T.9S., R.7E., W.M., in Marion County approximately $95 \mathrm{~km}$ east of Salem. Detroit with a population of 340 is $16 \mathrm{~km}$ southwest of the hot springs.

- The KGRA is located in rugged forested land in the Western Cascades. The Breitenbush Geothermal Area (BGA), as designated by the Forest Service, covers 44,283 acres in both the Western and High Cascade regions. The hot springs in the KGRA are situated in a valley just downstream from the confluence of the North and South forks of the Breitenbush River. Elevations in the KGRA range from about 610 meters $(2,000 \mathrm{ft}$.) at the river bottom to 1,380 meters $(4,528 \mathrm{ft}$.) at Devil's Peak. Slopes vary from moderately steep to precipitous.

The forest products industry is the mainstay of the region and the Breitenbush area is highly valued for its timber production capabilities. Clear cutting is a common logging method. Although a small portion of the timber is transported to the Willamette Valley for processing, most of it is milled in the Upper North Santiam area. Towns such as Idanha are based on mill operations that depend heavily on timber from the surrounding National Forest lands.

The Breitenbush orea is also widely used for recreational purposes. There are two existing campgrounds in the KGRA and the Forest Service has identified 19 potential recreation sites. Recreation is not limited to the summer months. During the winter cross-country skiing and snowmobiling are popular activities. Trails in the vicinity which provide access to the adjacent Mt. Jefferson Wilderness area are heavily traveled.

With the exception of a small parcel of privately owned land at the hot springs, the Breitenbush KGRA is part of the Willamette National Forest. The broader Breitenbush Geothermal Area laps over on the northern edge into the Mt. Hood National Forest. 
Because the KGRA is located in a National Forest, population levels are low. A few year round residents live at the two hot springs resorts, but most of the human occupancy is transitory and related to recreational and logging activities. Small communities in the vicinity are situated east of Breitenbush along Highway 22. Estimated population for the towns of Detroit, Idanha, Gates, Mill City and Lyons is 3,500. Their economic base is related to forest products and recreation. Local residents are concerned that geothermal development will create adverse environmental impacts on the recreation industry.

Geothermal energy potential is illustrated by the fact that Breitenbush Hot Springs is the most extensive thermal spring system in the Oregon Cascades. The main group of springs flow from the contact of a north-trending basaltic dike with Breitenbush Tuffs. Other springs flow through the alluvium and glacial outwash deposits. The average spring temperature is $92^{\circ} \mathrm{C}$ and total approximate flow rate is $3,400 \mathrm{lpm}$. Geothermometry indicates that temperatures as high as $150^{\circ} \mathrm{C}$ are possible at depth. The large volume of flow, high chloride content $(1,300 \mathrm{mg} / \mathrm{l})$ of the water and a slightly alkaline $\mathrm{pH}$ (7.31) are indicative of a hot-water-dominated convection system.

Several wells have been drilled in the area which further indicate the presence of a hydrothermal system. At Breitenbush Hot Springs resort a 152 meter (500 ft.) well was drilled which produced $50 \mathrm{gpm}$ of $100^{\circ} \mathrm{C}$ water. The well is supplying heat to cabins and a swimming pool.

As well, the Oregon Department of Geology and Mineral Industries has drilled two temperature gradient holes in the Breitenbush area. Average gradients were $55.2^{\circ} \mathrm{C} / \mathrm{km}$ and $90.6^{\circ} \mathrm{C} / \mathrm{km}$. Sunoco Energy Development Company has also drilled a test well to 366 meters $(1,200 \mathrm{ft}$.$) , but gradient$ information has not been released.

The $150^{\circ} \mathrm{C}$ estimated base reservoir temperature at Breitenbush is not within the conventional range for consideration of electrical generation. However, there is speculction that greater temperctures may be proven by deep test cirilling.

The presence of existing transmission lines that could carry additional loads within the KGRA and proximity to the energy-hungry Willamette Valley are favorable factors in considering Breitenbush as a potential electrical generating site. Yet the existence of a resource capable of electrical production has not been demonstrated. Nevertheless, the area's proximity to the Mr. Jefferson Wilderness Area and other scenic reserves and the intensity of public sentiment could preclude any geothermal electrical development even if a sufficient resource were discovered. 
The potential for direct use applications of geothermal energy appears more promising. Given the high temperatures at Breitenbush, a wide range of non-electric end uses could be postulated. Utilization is limited, however, because the area is sparsely populated.

Transporting thermal fluids from the Breitenbush area east towards the Willamette Valley could help meet energy demands in industrial, commerical and residential sectors. Lumber operations along Highway 22 could utilize geothermal resources for kiln drying. With geothermal heating available, secondary industries such as finished wood products could be attracted to the area and use low cost energy for processing or space heating. The availability of geothermal energy for space heating attracted a large manufacturing concern to Klamath Falls where the company realized a 60 percent savings in fuel cost.

Food processing operations in the lower Santiam area are large energy consumers that could be potential end users. A mushroom plant which could utilize temperatures in the $50^{\circ} \mathrm{C}$ range is located on the east side of Salem. Energy consumption figures for two food processors in the Salem area are included in Appendix B. In addition to these and other agriculturally related uses, the opportunity for district heating systems in Mill City, Stayton and Salem are good.

Transmission systems with distances of 50 and $100 \mathrm{~km}$ are being designed and theoretically proven economical for the Akureyri district heating system in Iceland. But, it has yet to be proven that geothermal water can be delivered this distance with sufficient temperature and within economic reason. With this in mind and given the undefined characteristics of the Breitenbush geothermal resource, any projections of use distant from the site are highly speculative.

In the short term, it is likely that use of thermal waters will increase at the two resorts. Expanded use for space heating is anticipated as the facilities are upgraded. A greenhouse to help meet the needs of the developing community at Breitenbush Hot Springs is a likely development.

Breitenbush Hot Springs have been enjoyed as health resorts since the 1940s. Brochures from one resort claimed the mineral water offers "remarkable cures of rheumatism, liver and kidney troubles, neuritis, arthritis, diabetes, eczema, gout, constipation, nicotine habit, and other chronic ailments". Today the thermal springs are used for space and pool water heating and for bathing. The Lower Camp at Breitenbush Hot Springs is frequented by persons known as the "Old Believers" who follow Russian Orthodox customs. 
As indicated by Sunoco Energy's temperature gradient well industry is interested in the Breitenbush geothermal resource. Non-competitive lease applications have been filed on land surrounding the KGRA to the north and south and on the east side bordering the Mt. Jefferson Wilderness area. Applications in areas approved by the Forest Service for leasing were being processed by the BLM in late 1978. This is part of a large lease play taking place in the area between Carey and Breitenbush Hot Springs in an effort by private and public concems to obtain geothermal leases. Lands in the KGRA cleared for leasing were offered for competitive bidding on October 19, 1978. Sunoco Energy was the sole bidder and successfully acquired leases on 5,818 acres.

Despite this development interest, utilization of the Breitenbush area geothermal energy resources could easily be restricted by environmental and land use concerns. Two areas covering 9,773 acres adjacent to the Breitenbush KGRA are being examined by the Forest Service in the RARE II process for possible inclusion in the National Wilderness Preservation System. The Draft RARE II environmental statement has classified neither area as being copable of producing, proven or possible geothermal resources.

Environmental issues will also be a significant factor effecting geothermal development. A great deal of concern has been expressed in response to the BGA environmental statement addressing geothermal leasing by Governor Straub, the League of Women Voters, the City of Detroit and others. These environmental concerns will demand that any development programs be carefully planned and conducted with local cooperation if the resource is to be utilized. 
SITE DATA SUMMARY

SITE: BREITENBUSH HOT SPRINGS, KGRA

..Physical Reservoir Data

.. Temperature ${ }^{\circ} \mathrm{C}$

Surface: $92^{\circ}(1)$

Subsurface: $150^{\circ} \mathrm{C}$ (estimated)(1)

.. Total Dissolved Solids (PPM): 2,400

..Type of Overlaying Rock: Andesite

..Estimated Depth to Top of Reservoir (meters): 1,500

.. Site Land Status

44,283 acres have been identified as prospectively valuable for geothermal resources by the USGS

Total Acres (KGRA): FEDERAL - 13,445 PRIVATE: 2,917 (BGA)

Total Acres Leased: FEDERAL $-5,818$

..Geothermal Development Status:

Limited exploratory work.

Space heating of resort cabins and swimming pool heating.

..Local and State Attitude Toward Geothermal Development:

Extreme sensitivity appears to be the prevalent local attitude.

..Land Use and Population:

Primary land use is for timber production and recreation.

Population is transitory in nature.

..Comments and Critical Issues:

In general, geothermal development in the Cascades is likely to be controversial and keenly watched by the public. . 
SITE LOCATION AND PHYSICAL DESCRIPTION

SITE: BREITENBUSH HOT SPRINGS, KGRA

.. Latitude: $44046^{\prime} 9$ " $\mathrm{N}$.

..Longitude: $121^{\circ} 58^{\prime} 5^{\prime \prime} \mathrm{W}$.

..Rectilinear: Secs. 7-9, 15-22, 28-30, T.9S., R.7E., W.M.;

Secs. 4 \& 23, T.8S., R.7E., W.M.; Secs. 2, 11 , $14,27,36$, T.9S., R.7E., W.M.

.. County: Marion

..Adjacent Counties: Clackamas, Linn, Jefferson, Wasco

..Maps: U.S.G.S. Topographic - Breitenbush Hot Springs 1:62,500

AMS - Bend $1: 250,000$

. . Topography

Rugged forested land in the Western Cascades. Elevations range from about $610 \mathrm{~m} .(2,000 \mathrm{ft}$.$) to 1,656 \mathrm{~m}$. $(5,434 \mathrm{ft}$.$) at$

Triangulation Peak. The hot springs and surrounding low lying areas are characterized by thick layers of glacial till which cover the bedrock patterns. As a result of glaciation, lateral, terminal and medial moraines are generally evident throughout the area. Numerous faults, flow and stream lineations are concentrated in the KGRA. Drainage follows a dendritic pattern. (28)

..Present Land Use:

Highly valuable timber production, with a substartial amount of clear cut areas. Recreation is second in importance only to timber in the economy of the Upper North Santiam and Clackamas Valleys. Two campgrounds, 2 recreation/residence tracts, 1 organization site, and 2 resorts are located within the KGRA. No grazing allotments are outstanding at the present time.

..Future Land Use Plans:

The U.S. Forest Service has identified 19 potential recreational sites within the KGRA. Long range use of Whitewater Rock Quarry (Sec. 28, T.10S., R.7E.) will preclude any geothermal development at the site. (28) 
..Aesthetics:

High aesthetic value.

The following areas are in close proximity to the Breitenbush KGRA: Mt. Jefferson Willderness Area, Bull of the Woods Roadlesss area, North Breitenbush and Minto Mountain Wilderness Study area, and 01 allie Lake Scenic area.

..Historical/Archaeological Significance:

A check of the Federal Register, Vol. 41, No. 28, Februrary 10, 1976, pages 6,008-6,009 and subsequent Federal Registers through Vol. 41, No. 121 has shown that not sites or structures within the area are listed on, or nominated for, the National Register of Historic Places.

In September 1975, the Department of Anthropology at the University of Oregon conducted a five percent archaeological survey of the area. Eleven sites were recorded. Lease terms will require protection of the eleven known sites, as well as any additional sites that may be discovered during geothermal development. (5)

..Other Land Uses:

Structures Within Area:

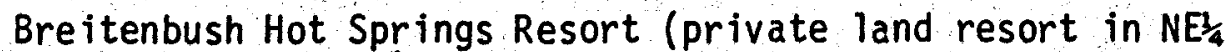
S.20, T.9S., R.7E.)

Breitenbush Hot Springs Resort (under Forest Service Special Use Permit in NW/3 Sec. 20, T.9S., R.7E).

Breitenbush Guard Station (Forest Service Administrative Site $\mathrm{NW}^{2} \frac{1}{4}$ Sec. $21, \mathrm{~T} .95, \mathrm{R} .7 \mathrm{E}$.)

Recreatior Sites: Breitenbush Campground; Cleator Bend Picnic Ground; Whitewater Campground; Whispering Falls Campground;

Riverside Campground

Organization Sites: Villa Maria Lodge; Chemeketans Cabin

Recreation Residence Sites: Breitenbush Forks Tract; Devils Creek Tract 


\section{Special Permits:}

- Permit covering 1.8 acres providing for operation of a small power plant to service the resort facilities (held by owners of Breitenbush Resort).

- Permit for a spur road in sections 7, 17 and 20, T.9S., R.7E. (held by resort owners)

- State of Oregon holds a mineral materials permit for removal of rock in section 28, T.10S., R.7E.

- Valley Telephone Company has a permit for a telephone cable in sections 19, 20, 28, 29 and 33, T.10S., R.7E., and section 3, T.11S., R.7E.

- Forest Service plans for long range use of Whitewater Rock Quarry in NE $\frac{1}{4} \mathrm{SW}_{4}^{2}$, section $28, T .10 \mathrm{~S}$., R.7E.

- Marion County is permitted for a disposal site in SE $\frac{1}{4}$ SW $\frac{1}{4}$, section 14, T. 10S., R.6E.

- Consumers Power, Inc. holds a powerline permit in parts of section 10, T.10S., R.6E., parts of sections 19, 20, 28, 29, and 33, T.10S., R.7E, and section 3,T.11S., R.7E.

- Chemeketans hold a right-of-way permit in part of section 21, T.10S., R.7E. (28)

\section{Land Withdrawn from Mineral Entry:}

- Under Executive Order 10355, parts of sections 19, 20 and 21 have been withdrawn for recreation purposes.

- The Federal Power Commission has withdrawn for power purposes parts of sections 14 and 15, T.10S., R.6E., and parts of sections 19,20,21, 28, and 33, T.10S., R.7E.

- U.S. Geological Survey has withdrawn for power purposes under Power Site Classification No. 291, parts of section 10, T.10S., R. 6 E., and parts of sections 19, 20, 28, 29 and 33, T. TOS., R.7E.

Compatibility With Land-Use Plans:

The U.S. Forest Service has reviewed the ir proposed geothermal leasing with Oregon Land Conservation and Development Commission (LCDC) and Marion and Linn County planners. Actions are consistent with existing Marion and Linn County plans and generally consistent with LCDC goals and guidelines. Conflicts with the goals include loss of some land for open space and recreation use and possible loss of opportunity for designating part of the South Breitenbush River as a state or federal Scenic Waterway. Degradation of quality of open space, scenic, recreation, air and water resources represent the most important conflicts. However, the proposed action (geothermal leasing) conform well with other LCDC goals, particularly the inventory and development of energy sources. (28) 


\section{GEOLOGICAL/GEOPHYSICAL DESCR IPTION}

SITE: BREITENBUSH HOT SPRINGS, KGRA

\section{Geology}

The Breitenbush geothermal area jies in the Cascade Mountain Range which is primarily composed of Cenozoic volcanic rocks. The area is divided into two physiographic regions; the Western Cascades and the High Cascades. Both regions are represented in the Breitenbush geothermal area.

In the Western Cascades older rocks range from early 01 igocene to early Miocene age. Ash flows have deposited massive beds of andesitic and dacitic tuff. In less abundance are flows, breccia, tuff and small intrusions of dacite and rhyodacite. Average thickness is $1,524-3,048 \mathrm{~m}$. (5,000-10,000 ft.).

Flows, flow breccia, tuff breccia, lapilli tuff, tuff and conglomerate of mid-Miocene to late Miocene origin comprise the younger rocks of the Western Cascades. Flows constitute between 50 and 90 percent of the formation. Average thickness is about $914 \mathrm{~m}$. $(3,000 \mathrm{ft}$. $)$ with some formations ranging up to $3,048 \mathrm{~m}$. $(10,000 \mathrm{ft}$.$) . The majority of the rocks are hypersthene andesite$ and contain phenocrysts of plagioclase and hypersthene in a dark aphanitic groundmass. Less common rock types are basaltic andesite; 01 ivine basalt, dacite and rhyodacite.

The High Cascades are composed of early Pliocene to Recent basalts and andesites. Vesicular flows of porous aphyric ol ivine andesite and olivine basalt are characteristic. Ash, pumice, tuffs and cinder deposits are also common. Although the western margins of the High Cascades show effects of glaciation, the region is less extensively eroded than the older rocks of the Western Cascades.

Geologic mapping of the Breitenbush area has been done by Clayton (1976) and in reconnaissance manner by Hammond (1976).

The oldest exposed unit is the Detroit Formation of 01igocene age. It is composed of well stratified basaltic lapilli tuff and lapilli breccia interbedded with tuffaceous sandstone. The formation is well exposed along the Breitenbush River at Detroit and trends to the west increasing in proportion of lavas per volume. 
West of the hot springs, along the Breitenbush River, is an extensive out cropping of Breitenbush Tuffs. The unit consists of crystal-vitric ash-flow tuffs interstratified with tuffaceous sandstone and pebble conglomerate. The formation has a maximum thickness of $792 \mathrm{~m} .(2,600 \mathrm{ft}$.$) and is thought to extend beneath the$ High Cascades.

The Outerson Formation unconformably overlies the Breitenbush Tuffs and is thought to be the erosional remnants of a large shield volcano complex originating from basalt dikes and plugs. It includes phyric olivine basalt flows and interbedded scoriaceous breccia and minor volcanic sediments. The Outerson Formation is evident to the north, south and east of the Breitenbush Hot Springs.

Structurally the predominant feature is the Breitenbush anticline, a double-plunging open-fold trending generally northeast-southwest. Clayton (1976) has located various north-northwesterly trending faults in the area which have been downthrown on the east side.

Breitenbush Hot Springs, discharging from 40 to 60 orifices, is the most extensive surface manifestation of a thermal spring system in the Oregon Cascades. The primary group of springs flow from the contact of a north-trending basaltic dike with Breitenbush Tuffs. Others arise through the alluvium and glacial outwash deposits. With an average temperature of $92^{\circ} \mathrm{C}$ the springs have an approximate flow rate of $3,4001 \mathrm{pm}$ in a $0.1 \mathrm{~km}$ area.

(28) (21) (29) (10)

\section{Mineral Occurrences}

Private lands around the Breitenbush Hot Springs have been mined for localized depcsits of cinnabar which occurs as a result of secundary mineralization around the hot springs. No mining has taken place on Forest Service land. In the adjacent Little North Santiam River drainage minor deposits of gold, silver and low-grade iron ore have been mined in the past. In the Forest Service's estimation quarry rock for road construction and maintenance is the area's most valuable mineral resource. (28)

\section{Geophysical Summary}

A roving dipole resistivity survey of the Breitenbush Hot Springs area has been completed under contract to Sunoco Energy Co. 
References to geophysical surveys:

Couch, R. W., and Baker, B., 1977, Geophysical Investigations of the Cascade Range in Central Oregon: Final Report to U.S.G.S.

Hassemer, J. H., and Peterson, D. L., 1977, Principal Facts for a Gravity Survey of Breitenbush KGRA, Oregon: U.S.G.S. Open-File Report 77-67-A.

O'Donnel1, J. E., Broughan, G. W., Martinez, R., and Christopherson, K. R., 1977, Telluric Survey Data for Breitenbush KGRA, Oregon: U.S.G.S. Open-File Report 77-66-B.

U.S.G.S., 1977, Aeromagnetic Map of Breitenbush Hot Springs and Vicinity, Oregon: Open-File Report 77-820.

Geologic Hazards:

Seismic intensity levels are low compared to many other areas in Oregon. Mt. Jefferson, a major peak adjacent to the KGRA, showed a daily incidence of 0.6 micro earthquakes. (28)

Given the competent nature of the igneous rock formations, the possibility of land subsidence is extremely low.

There are some bedrock hazards due to the inherently weak rock units which have low shearing resistance. Large scale creep and block sliding problems are present where erosional processes have formed steep slopes and canyons in weathered volcanic debris, clay seams and interbedded ash and sedimentary rock units. (28). 


\section{RESERVOIR CHARACTERISTICS \\ SITE: BREITENBUSH HOT SPRINGS KGRA}

. Reservoir Temperature

Surface: $92^{\circ} \mathrm{C}(1)$

Subsurface: $150^{\circ} \mathrm{C}$ estimated $(1)$

..Geochemical: (Estimted minimum)

Silica Conductive: $127^{\circ} \mathrm{C}$

Na-K-1/3Ca: $\quad 149{ }^{\circ} \mathrm{C}$

Silica Adiabatic: $124^{\circ} \mathrm{C}$

$\mathrm{Na}-\mathrm{K}-4 / 3 \mathrm{Ca}$ :

$128^{\circ} \mathrm{C}$

..Flow Rates: 3,400 1pm (8)

..pH: 7.31

(8)

.Total Dissolved Solids: 2,400 ppm

..Fluid Chemistry:

High chloride content, large volume of flow and a slightly alkaline $\mathrm{pH}$ are indicative of a hot-water-dominated convection system.

Breitenbush Hot Springs

Specific Conductance (micromhos)
Silica
Calcium
Magnesium
Sodium
Potassium
l.ithium
Bicarbunate
Carbonate
Sulfate
Chloride
Fluoride
Boron

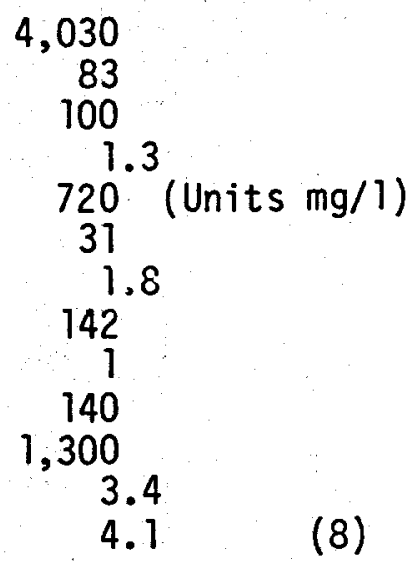

..Estimated Reservoir Heat Content: .2 $.210^{18} \mathrm{cal}$

..Subsurface Area of Reservoir: Estimated $1.5 \mathrm{~km}^{2}$

Breitenbush Hot Springs are located in Sec. 20, T.9S., R.7E., W.M. 
LAND OWNERSHIP AND LEASING

SITE: BREITENBUSH HOT SPRINGS KGRA

..Land Ownership

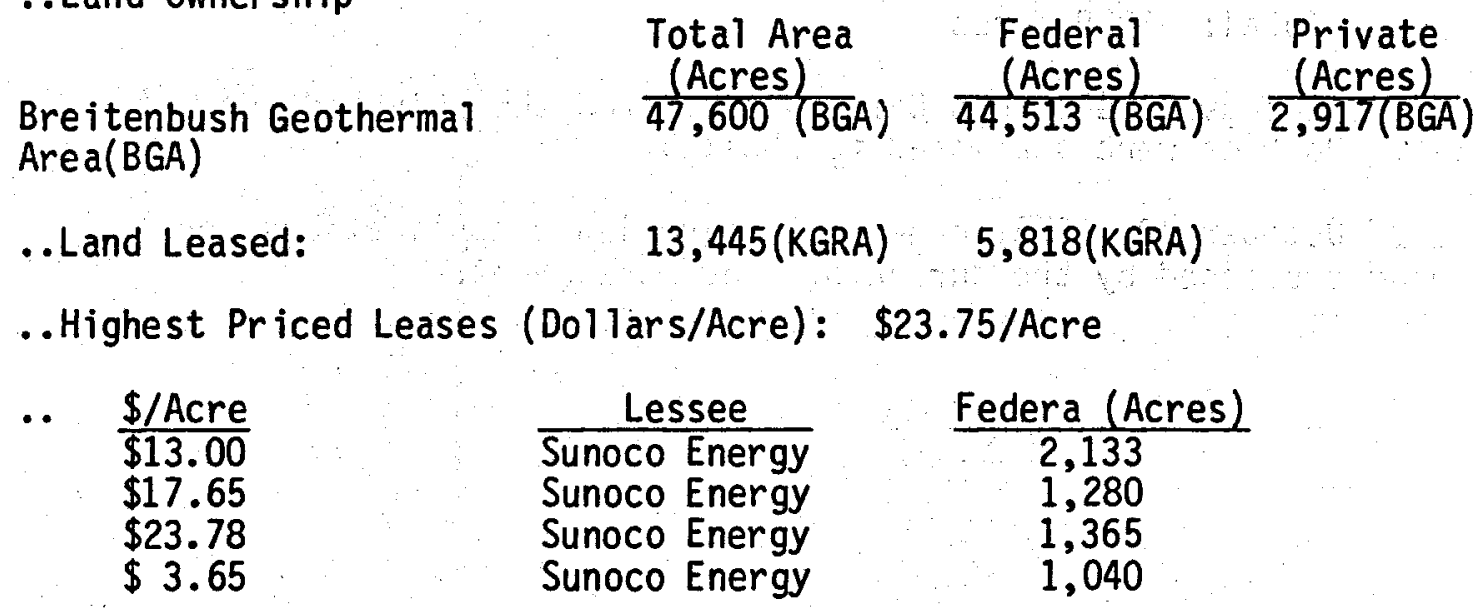

..Tentative Lease Sale Dates: Lease sale was held October 19, 1978

..Summary of Leasing Status and Needs:

The U.S. Forest Service has approved the following leasing recommendations:

Non-competitive application lands to be offered Non-competitive application land to be withheld KGRA lands to be offered KGRA lands to be withheld

19,974 acres 11,264 acres 6,844 acres 6,601 acres

The following units of the Breitenbush KGRA were offered for competitive bidding on October 19, 1978:

Unit 1: T.9S., R.7E. Willamette Meridian

Sec. 7-all, Sec. 8-all,

Sec. $17-N_{\frac{3}{2}}^{1} N_{\frac{2}{2}} S W_{\frac{1}{4}}$, Sec. $18-N_{\frac{1}{2}} N_{\frac{2}{2}} S_{\frac{1}{4}}^{\frac{1}{4}}$

Total: 2133.40 acres

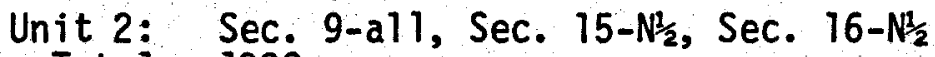

Tota1: 1280 acres

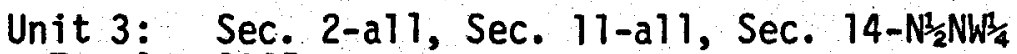

Total: 1365 acres 


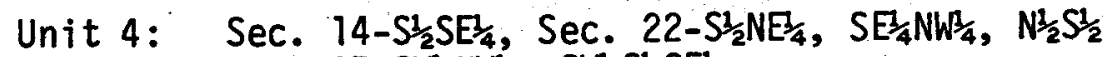

Sec. $27-\mathrm{SW}_{\frac{1}{4}} \mathrm{NW}_{\frac{1}{4}}, \mathrm{SW}_{\frac{1}{4}} \mathrm{~S}_{\frac{2}{2}} \mathrm{SE \frac {1 } { 4 }}$

Sec. $28-S_{\frac{1}{2}} \mathrm{NE}_{\frac{1}{4}}, \mathrm{~S}_{\frac{1}{2}}$

Total: 1040 acres

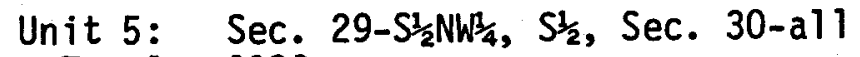

Total: 1029 acres

Sunoco Energy Development Company submitted the only bids on Units 1-4. No bids were submitted for Unit 5.

As of October 10,1978, non-competitive lease applications were being processed by the Bureau of Land Management. 
GEOTHERMAL DEVELOPMENT STATUS

SITE: BREITENBUSH HOT SPRINGS KGRA

..Present Development Status:

There are two existing resorts, locally known as "Lower Camp" and "Upper Camp", at Breitenbush Hot Springs. The Lower Camp uses hot water for a bath house. The owner of the Upper Camp has drilled a $500 \mathrm{ft}$. well on private land under a water well permit. (30) The well flows at $50 \mathrm{gpm}$ with an approximate bottom hole temperature of $100^{\circ} \mathrm{C}\left(212^{\circ} \mathrm{F}\right)$ and is used for supplying heat to cabins and a swimming pool.

Sunoco Energy Co. holds two State geothermal prospect well permits in the Breitenbush area on federal 1and. The company drilled a $1200 \mathrm{ft}$. temperature gradient hole in December 1977. The hole is located in the SW/ section 29, T.9S., R.7E. W.M. about two miles from Breitenbush Hot Springs. Data from the gradient hole has not been publicly released. (30)

The Oregon Department of Geology and Mineral Industries drilled two shallow temperature gradient holes in the Breitenbush area. Data from the holes is listed on the following page.

..Projected or Planned Development:

Lower Camp at Breitenbush Hot Springs came under new ownership in mid 1978. The new proprietor plans to make gradual changes to supply space heating to the cabins and to open the resort year round.

Breitenbush Hot Springs Resort is being developed as a self-sufficient community which will be opered to the public for workshops and seminars stressing holistic health and spiritual awareness. Plans include expanded use of geothermal water for space heating and possibly a greenhouse. (3i)

It is anticipated that exploration activities will increase after competitive and non-competitive leases have been acquired in late 1978. 
Location: Sec. $21 \mathrm{SEE}_{4} \mathrm{NEE}_{4}$, W.M., T.9S., R.7E.

Map Reference: AMS Salem, Oregon

Date Measured: 9/30/76

\begin{tabular}{|c|c|c|c|c|c|}
\hline DEPTH & DEPTH & TEMPI & TURE & GEOTH & GRADIENT \\
\hline METERS & FEET & DEG C & DEG F & DEG C/KM & DEG F/100 FT \\
\hline 5.0 & 16.4 & 8.550 & 47.39 & .0 & .0 \\
\hline 10.0 & 32.8 & 8.200 & 46.76 & 70.0 & 3.8 \\
\hline $\begin{array}{l}13.0 \\
20.0\end{array}$ & $\begin{array}{l}49.2 \\
65.6\end{array}$ & $\begin{array}{l}9.090 \\
9.430\end{array}$ & $\begin{array}{l}48.30 \\
48.97\end{array}$ & $\begin{array}{r}68.0 \\
68.0\end{array}$ & $\begin{array}{l}9.8 \\
3.7\end{array}$ \\
\hline 25.0 & 82.0 & 9.800 & 49.64 & 74.0 & 4.1 \\
\hline 30.0 & 98.4 & 10.080 & 50.14 & 56.0 & 3.1 \\
\hline 35.0 & 114.8 & 10.530 & 50.95 & 90.0 & 4.9 \\
\hline 40.0 & 131.2 & 11.170 & 52.11 & 128.0 & 7.0 \\
\hline 45.0 & 147.6 & 11.740 & 53.13 & 114.0 & 6.3 \\
\hline 50.0 & $\begin{array}{r}164.0 \\
180.4\end{array}$ & $\begin{array}{l}12.390 \\
13070\end{array}$ & $\begin{array}{l}54.30 \\
55.53\end{array}$ & 130.0 & $\begin{array}{l}7.1 \\
7.5\end{array}$ \\
\hline $\begin{array}{l}55.0 \\
60.0\end{array}$ & 196.8 & 13.620 & $\begin{array}{l}55.55 \\
56.52\end{array}$ & 110.0 & 6.0 \\
\hline 56.0 & 213.2 & 14.140 & 57.45 & 104.0 & 5.7 \\
\hline 70.0 & 229.6 & 14.820 & 58.68 & 136.0 & 7.5 \\
\hline $\begin{array}{r}75.0 \\
80.0\end{array}$ & $\begin{array}{l}246.0 \\
262.4\end{array}$ & 15.070 & 59.13 & 50.0 & $\begin{array}{l}2.7 \\
5.5\end{array}$ \\
\hline $\begin{array}{l}80.0 \\
85.0\end{array}$ & 278.8 & 16.110 & 61.00 & 108.0 & 5.9 \\
\hline 0.0 & 295.2 & 16.480 & 61.66 & 74.0 & 4.1 \\
\hline 95.0 & 311.6 & 16.990 & 62.58 & 102.0 & 5.6 \\
\hline 100.0 & 328.0 & 17.520 & 63.54 & 106.0 & \\
\hline 105.0 & 344.4 & 17.890 & 64.20 & 74.0 & 4.1 \\
\hline 110.0 & 360.8 & 18.350 & 65.03 & 92.0 & 5.0 \\
\hline $\begin{array}{l}115.0 \\
170.0\end{array}$ & 377.2 & $\begin{array}{l}18.800 \\
19.270\end{array}$ & 65.84 & $\begin{array}{l}90.0 \\
94.0\end{array}$ & $\begin{array}{l}4.9 \\
5.2\end{array}$ \\
\hline 125.0 & $\begin{array}{l}393.0 \\
410.0\end{array}$ & 19.630 & $\begin{array}{l}00.09 \\
67.33\end{array}$ & 72.0 & $\begin{array}{l}0.2 \\
4.0\end{array}$ \\
\hline 130.0 & 420.4 & 19.990 & 67.98 & 72.0 & \\
\hline 135.0 & 442.8 & 20.660 & 69.19 & 134.0 & 7.4 \\
\hline 140.0 & 459.2 & 21.120 & 70.02 & 92.0 & 5.0 \\
\hline 14 & 47 & & & 102.0 & 5.6 \\
\hline 15 & & & & 120.0 & 6.6 \\
\hline
\end{tabular}

Average Gradient $10-150$ meters $-90.6^{\circ} \mathrm{C} / \mathrm{Km}$ 
Location: Sec. 23 NW的W $\frac{1}{4}$, W.M., T.9S., R.6E.

Map Reference: AMS Salem, Oregon

Date Measured: 9/30/76

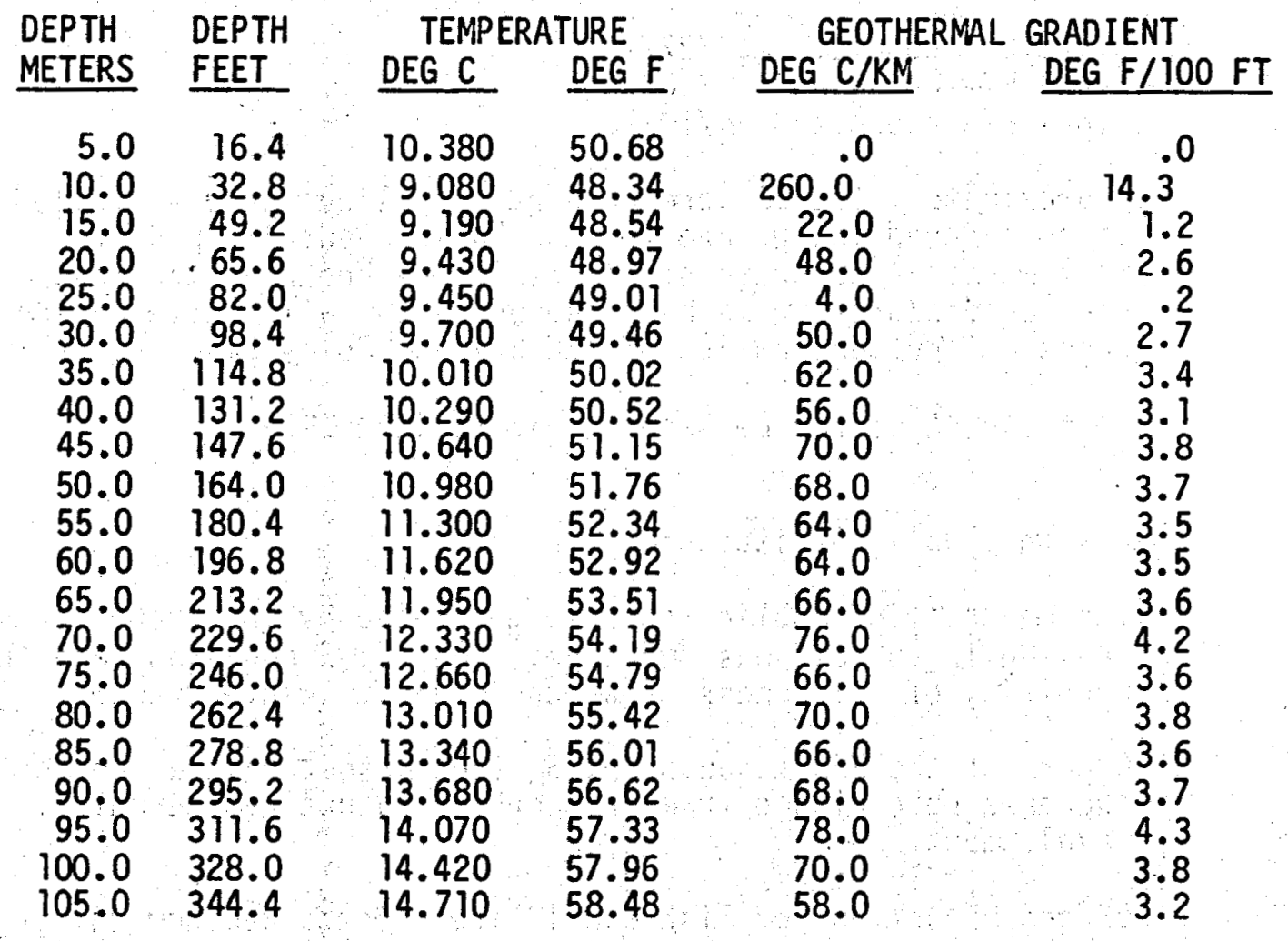

Average Gradient $10-105$ meters $-55.2{ }^{\circ} \mathrm{c} / \mathrm{Km}$ (24) 
INSTITUTIONAL CONSIDERATIONS

SITE: BREITENBUSH HOT SPRINGS KGRA

.. Status of Requirements (i.e., EIA/EIS Requirements)

Draft EIS completed 10/27/76

Final EIS released $1 / 10 / 78$

Final EIS approved $4 / 10 / 78$

Approximately 12,000 acres of lease application area failed to be considered in the Breitenbush Environmental Impact

Statement. A separate statement, to be known as the West

Breitenbush area, will be prepared by the Willamette National

Forest after publication of the Belknap-Foley EIS.

Tentative time for release is mid to late 1979.

...Agency and Public Attitudes:

The majority of public response generated by the proposed leasing in the EIS was negative. The major concerns were the proximity of wilderness areas and big game winter range.

Owners of the Breitenbush Hot Springs Resort have urged that the area be excluded from present and future geothermal development.

Oregon Department of Fish \& Wildl ife recommended removal of areas delineated as big game winter range from any surface occupancy.

Oregon Governor Bob Straub responded to the druft and final EIS and urged caution in proceeding with geothermal development in scenic areas. He said that Oregon does not yet have a clear understanding with Federal agencies on regulation of a commercially-developed geothermal field on federal land. He suggests that the Forest Service limit leasing and plan to restrict development to a small area with evidence of promising geothermal resources and minimal environmental impacts.

On May 10, 1978, the City of Detroit filed a "Notice of Appeal" to the U.S. Forest Service concerning geothermal leasing in the Breitenbush area. 
According to the appeal, the City of Detroit Draft Comprehensive Plan states the following: "The City of Detroit is concerned about geothermal development in the Breitenbush area, if it would create strongly negative impacts on the environment. The City is not opposed to geothermal development per se, but they do feel that strong safeguards should be used to control the environmental impacts of a development." Therefore the City has adopted the following policy:

If geothermal development in the Breitenbush area should occur, it should be of the type that causes the least environmental damage.

The City requests the following assurances:

- The best mitigating technology to minimize air, noise, odor and water quality impacts to the environment.

- An enclosed system will be included in the development project.

- The applicant will pay for any costs borne to the

City due to increased population pressures created by the geothermal developments (e.g. sewers, water facilities, roads, etc.).

- An in-depth study of potential social-economic impacts to Detroit be required prior to development of a geothermal project in the Detroit area.

- No temporary communities will be formed for the purpose of housing employees for the geothermal development.

A coalition of environmental groups and individuals have also filed notice of appeal with the Forest Service claiming that the EIS was inadequate in proving that construction of a geotnermal power plant would not adversely effect the Breitenbush area.

Both appeals were denied by the regional forester thereby clearing the way for the October 19, 1978 competitive lease sale. 
...Institutional Requirements:

Two areas adjacent to the Breitenbush KGRA are being examined by the U.S. Forest Service as part of the RARE II process. As a result of the review, the following designations are possible: recommend for inclusion in the National Wilderness Preservation System, recommend for further study, return to multiple-use status.

According to the Forest Service classification, neither area has producing, proven or possible geothermal resources.

The areas are as follows:

$\begin{array}{ccccc}\text { Area } & \begin{array}{l}\text { Area } \\ \text { Code }\end{array} & \frac{1}{\text { Administrative }} \begin{array}{c}\text { Total } \\ \text { District }\end{array} & \text { Acreage } \\ & 099 & \text { Mt. Hood National Forest } & 8,673 \\ \text { Mt. Jefferson } & 101 & \text { Willamette National Forest } & 1,100\end{array}$

(Area code 101 is suggested as an addition to the existing Mr. Jefferson Wilderness) 


\section{ENVIRONMENTAL FACTORS}

SITE: : BREITENBUSH HOT SPRINGS KGRA

.CLIMATE - No weather stations are located in the KGRA. Data is from the Detroit Fish Hatchery station.

..Prevailing Winds: Varying from southwest to northwest.

..Precipitation (Annual): $208 \mathrm{~cm}$

. Average Temperature: $49.10^{\mathrm{F}}$

Minimum: $36.90^{\circ} \mathrm{F}$

Maximum: $61.20 \mathrm{~F}$

..Degree Days (Annual): 6026 (Detroit)

. Relative Humidity (Seasonal Peaks)

Sumer: $40-50$ percent

Winter: $70-90$ percent

-. AIR QUALITY:

No measuring stations are located in the area. Generally the air quality is excellent due to the area's remoteness from urban centers. The primary sources of present air pollution are dust from unpaved roads, smoke from slash burning and field burning in the Willamette Valley. (28)

. WATER QUALITY:

Waters of the KGRA drain into the North Santiam and Clackamas River systems. The average discharge of the North Santiam River measured over a 48-year period at a gauging station 0.5 miles below Boulder Creek is 1,015 cu. ft. per second or 735,400 acre-feet. (not in KGRA) The sediment yield of streams in the Williamette Basin is low because of favorable physiographic and climatic conditions. USGS water temperature profiles indicate a mean temperature of $52{ }^{\circ} \mathrm{F}$ for the Breitenbush River outlet with a minimum of $430 \mathrm{~F}$ and a maximum of $600^{\circ} \mathrm{F}$. A mean temperature of $53^{\circ} \mathrm{F}$, minimum of $44^{\circ} \mathrm{F}$ and maximum of $640 \mathrm{~F}$ were recorded for the North Santiam River below Boulder Creek. Streams in the area are tributary to rivers tapped for domestic water at recreation sites and urban areas including Oregon City, Estacada, Detroit and Idanha. (28) 
..NOISE:

No measuring stations are maintained in the area. Given the area's distance from urban centers, noise levels should be low.

. BIOLOGICAL

..Dominant Flora:

Douglas-fir forest covers approximately 70 percent of the area.

Principal associates: Douglas-fir (Pseudotsuga menziesii) Western Hemlock (Tsuga Heterophylla) Western Redcedar (Thuja plicata)

At elevations above $914 \mathrm{~m}$. (3,000 ft.) the dominant flora is the True fir-mountain hemlock forest covering approximately 13 percent of the area. (28)

..Dominant Fauna:

Big game population: Roosevelt elk, Black-tailed deer and Black bear.

A considerble portion of the KGRA is classified as big game winter range.

The North Santiam and Breitenbush Rivers are major fishing waters.

Information is not available on non-game animals.

.. Endangered Species:

Flora: Of primary concern is Aster gormanii. The plants' known range is restricted to the area between Jefferson Park and Breitenbush Lake. It is classified as threatened on the Smitrsonian Institution's proposed list of endangered

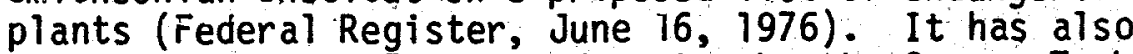
been proposed for Endangered status by the Oregon Task Force.

Other plants listed by the Oregon Task Force are known in the west central Cascades and may be in the area.

Sword fern

Wood fern

Bog birch

Cranberry

Reedgrass
(Polystichum californicum)

(Thelypteris nevadensis)

(Betula glandulasa)

(Vaccinium oxycoccus var. intermedium)

(Ca)amagrostis breweri) 


\begin{tabular}{|c|c|}
\hline $\begin{array}{l}\text { Washington } 1 \mathrm{ily} \\
\text { Bog orchid } \\
\text { Rue anemone } \\
\text { Matted saxifrage }\end{array}$ & $\begin{array}{l}\frac{(\text { Lilium Washingtonianum) }}{\text { Habenaria orbiculata) }} \\
\frac{\text { Isopyrum hallij) }}{\text { Saxifraga }} \frac{\text { bronchialis }}{\text { vespertina) }}\end{array}$ \\
\hline $\begin{array}{l}\text { Pinefoot } \\
\text { Tall agoseris } \\
\text { Alpine collomia } \\
\text { Crater Lake sar }\end{array}$ & $\begin{array}{l}\left(\frac{\text { Pityopus }}{\text { Agalifornicus }}\right) \\
\left(\frac{\text { Agoseris }}{\text { Collomia }} \frac{\text { elata) }}{\text { debilis var }} \text { larsenii) }\right. \\
\text { Arenaria }\end{array}$ \\
\hline
\end{tabular}

Fauna:

Aleutian Canada goose (Branta canadensis leucopareia)--known to migrate over and rest in the Willamette National Forest--it is unlikely that geese set down in the area because of scarcity of suitable habitat.

American peregine falcon (Falco peregrinus anatum)--no known nesting sites are known in area.

Arctic peregine falcon (Falco peregrinus tundrius)--most likely to be found in the area during migration periods and winter.

.. THREATENED SPECIES:

Wolverine (Gulo luscus)--one siting from the Mt. Jefferson Wilderness.

Northern Blad eagle (Haliaeetus leucocephalus alascanus)--no known nesting sites in area.

Northern spotted owl (Strix occidentalis caurina)--known to have nested successfulty in 1974 in Cub point area - less than 5 airline miles away. Its habitat is old growth Douglas-f ir forest. (28) 
TRANSPORTATION AND UTILITIES

\section{SITE: BREITENBUSH HOT SPRINGS KGRA}

..Utility or Energy Transmission Corridors and Facilities

Bonneville Power Administration (BPA) and Portland General Electric (PGE) have transmission lines that cross the KGRA on a common right-of-way north of the Breitenbush River.

BPA has one double-circuit line with a total capacity of $950 \mathrm{MW}$ at $230 \mathrm{KV}$ which passes through the area. Considering that thị right-of-way is one of the Cascade corridors for transmitting power from east of the mountains to the west, it is possible that the line could be replaced by a higher capacity line.

PGE has one single circuit $230 \mathrm{KV}$ transmission line currently carrying a 400 to $600 \mathrm{MW}$ load. An additional 600 MW may be possible on this circuit.

It is estimated that these load increases would be possible using existing towers. (28)

Detroit Reservoir is a nearby hydraelectric site.

Tumble Lake has been identified as a potential pumped storage facility site.

..Transportation Corridors or Facilities

..Road Servicing the Area

State Highway 22

State Highway 224

National Forest Sys tem Roads

Boulder Ridge Road

Breitenbush Road

Total of 735 miles of roads provide access to the area.

Mainl ine roads include Breitenbush Rd. S46, South Breitenbush Rd. S918, No. Breitenbush Rd. S920, Boulder Ridge Rd. S916, Pamelia Rd. 109 and Whitewater Rd. 1044. These roads and a considerable mileage of secondary roads are built to standards suitable for geothermal development operations. (28) 
POPULATION

SITE: BREITENBUSH HOT SPRINGS KGRA

..General Description of Population

The population of the Breitenbush geothermal area is basically seasonal. A few people reside year round at the hot spring resorts. The transitory population is comprised of Forest Service and logging employees, recreationists, and those with summer houses. Presence of these groups is concentrated in the non-winter months.

Approximately 71 summer homes are in the area.

U.S. Forest Service estimates 79,400 visitor days in the area in 1976. (28)

.. Economics

..Present Land Use:

Timber production is a vital part of the area's economy.

Of the 44,283 acres that have been identified as prospectively valuable for geothermal resources, the Forest Service has estimated a total standing merchantable volume of $1,835,000,000$ board feet. (28)

The operation of six lumber mills in the North Santiam area is largely dependent on timber from adjacent National Forest lands.

Recreation is also an essential component in the area's economy particularly in communities such as Detroit.

..Future Land Use:

Recreational use is likely to increase. The City of Detroit has adopted the following policy in its draft plan:

"Encourage growth in the commercial sector of the community, especially in those types of uses most compatible with the recreational nature of the community." 
SITE: BELKNAP-FOLEY HOT SPRINGS, KGRA OREGON 


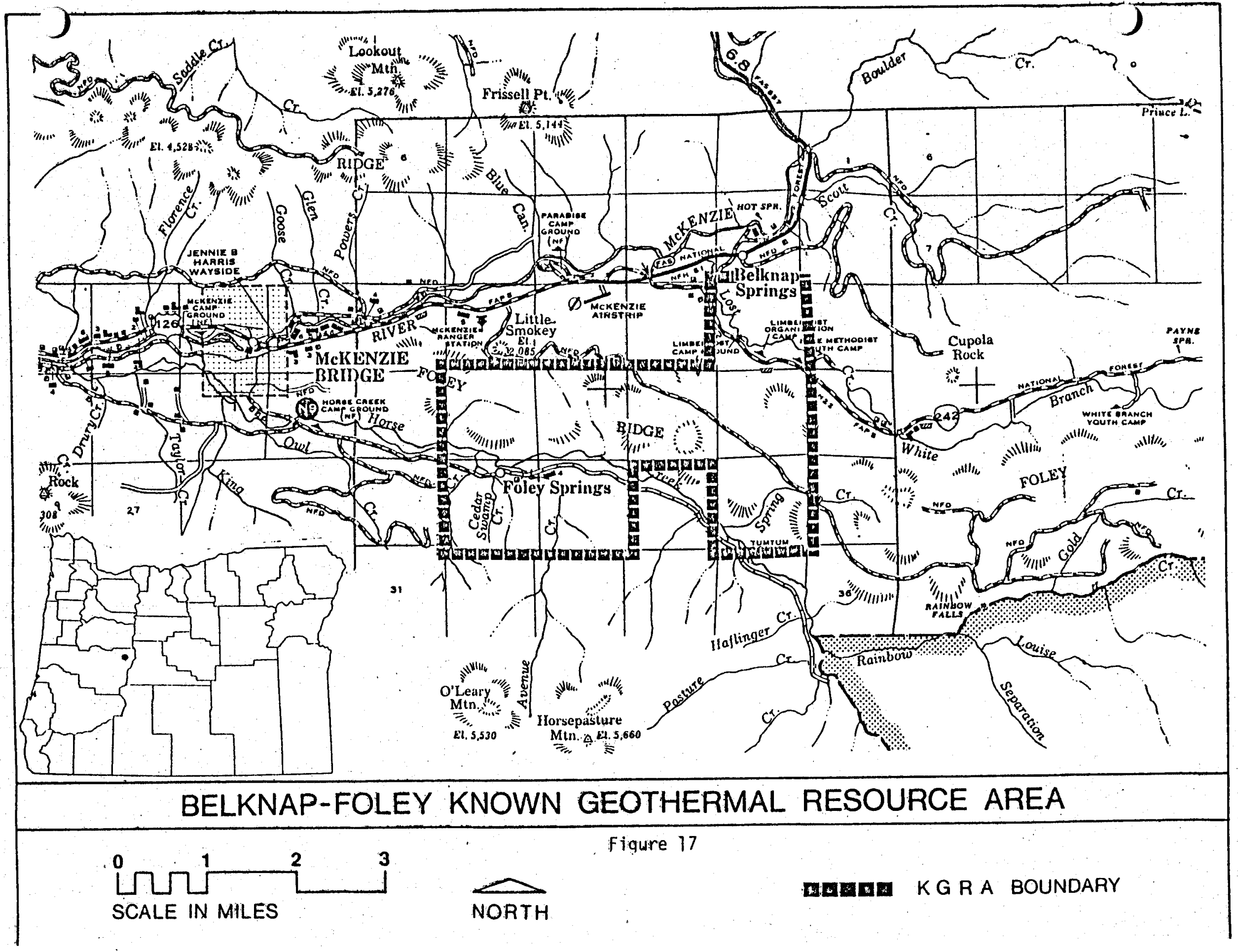




\section{BELKNAP-FOLEY HOT SPRINGS KGRA}

Covering 5,066 acres, the Belknap-Foley Hot Springs KGRA is situated in T.16S., R.6E., W.M., Lane County, Oregon. Population levels in the area are low. The nearest town is the small community of Mckenzie Bridge $10 \mathrm{~km}$ east of the springs. Larger centers are Eugene-Springfield (population 145,500) 87 kilometers west and Bend (population 17,100) is located about 90 kilometers over the mountains to the east.

The two hot springs are in the McKenzie River valley. The landscape is one of moderate to steep slopes covered predominately by Douglas fir forests. Elevations range from 485 meters $(1,591 \mathrm{ft}$.$) near the river to 1,097 \mathrm{~m}$. $(3,600$ $f t$.) at the southern boundary of the KGRA.

The Belknap-Foley KGRA and surrounding areas are managed as public land by the Willamette National Forest except for two private land parcels surrounding the hot springs. Both present land use and future plans stress timber production and recreation as a prime focus. Energy needs in the immediate area of the KGRA that could be satisfied with the geothermal resource are low given the present land use.

Belknap Hot Springs is situated north of Highway 126 known as the Mckenzie Highway and Foley is slightly south. Foley springs discharge $79{ }^{\circ} \mathrm{C}$ water at an approximate rate of $95 \mathrm{lpm}$. Belknap Hot Springs is the larger of the two and discharges $300 \mathrm{lpm}$ at $71^{\circ} \mathrm{C}$. A surface temperature of $86^{\circ} \mathrm{C}$ has also been reported for Belknap springs. Silica geothermometry indicate that temperatures in the $131-135^{\circ} \mathrm{C}$ may be possible at depth at Belknap Hot Springs. The water quality of Belknap-Foley Springs is suggestive of a hot-water-dominated hydrothermal convection system.

As part of the 1976 geothermal gradient driiling program by the Oregon Department of Geology and Mineral Industries two shallow wells were drilled in the Belknap-Foley area. Average gradients from 10 to 150 meters were $93^{\circ} \mathrm{C} / \mathrm{km}$ and $50^{\circ} \mathrm{C} / \mathrm{km}$.

The healthy $135^{\circ} \mathrm{C}$ minimum reservoir temperature estimated by the USGS for Belknap Springs opens a wide variety of possibilities for non-electric geothermal application. These include space heating, commercial processing and drying of organic materials, greenhouses, aquaculture, de-icing, and refrigeration. But, considering the minimal population, there is not a readily identifiable end user in the immediate area. If the resource was capable of being economically transported an 80-90 kilometer distance, it could contribute to the energy needs of Springfield, a major lumber processing center, and Eugene for district heating, greenhouses and agricultural processing. 
Interest has been shown in both Belknap and Foley hot springs for more than a hundred years. Belknap was homesteaded by R. S. Belknap in 1869 and Foley was developed for public use in 1870 by William Hanley and William Vick. The resorts were popular as health spas in the early 20th century. Foley Hot Springs is not currently in business, but Belknap operates as a resort offering a geothermally heated swimming pool and overnight accommodations. An interest in development remains, as evidenced by the Belknap Resort owner's plans to build a new pool and tubs, and to refurbish the lodge for year-round use. Geothermal space heating is being considered.

There is moderate interest in geothermal development in the Belknap-Foley area as expressed by industry and individual leasing activity. Lease applications have been filed since 1973. Approximately 1,700 acres of land covered in the applications overlap in the Mt. Washington and Three Sisters Wilderness Areas. Applications have been withdrawn or rejected on 1,080 of these acres. All other leasing fucntions, both competitive and non-competitive, must await publication and final approval of the environmental impact statement for the Belknap-Foley Geothermal Area. The Willamette National Forest is in the process of compiling the document with a draft scheduled for releose in mid 1979.

Environmental issues will effect geothermal exploration and development in the Belknap-Foley area. All of the KGRA, with the exception of 320 acres, lies within big game winter range. Forest service leasing in this area is questionable. Also of importance is the area's proximity, less than five miles, from the Mt. Jefferson, Three Sisters and Mt. Washington Wilderness Areas. 
SITE DATA SUMMARY

SITE: BELKNAP-FOLEY HOT SPRINGS KGRA

..Physical Reservoir Data

.. Temperature ${ }^{\circ} \mathrm{C}$

Surface: $71^{\circ} \mathrm{C} \quad$ Subsurface: $140^{\circ} \mathrm{C}$

..Total Dissolved Solids (PPM): 2,560 (Belknap)

.. Type of Over laying Rock: Olivine basalt

..Estimated Depth to Top of Reservoir (meters): 1,500

..Site Land Status - Primarily Willamette National Forest ownership.

Total Acres - 5,066 KGRA

Total Acres Leased - 0 Federal

..Geothermal Development Status:

The Belknap Resort heats the pool with thermal spring water.

..Local and State Attitude Toward Geothermal Development:

Considering the proximity to three wilderness areas, the public is likely to be extremely sensitive to any geothermal exploration or development.

This attitude is expressed by the general public and the U.S. Forest Service.

..Land Use and Population:

There are few permanen $\mathrm{c}$ residents in the immediate area, but an estimated population of 500,000 are within a $160 \mathrm{~km}(1-2$ hour drive) radius.

The area is heavily used for recreation and timber production purposes.

.. Comments and Critical Issues:

Belknap Foley Geothermal Area borders three Wilderness Areas Mt. Jefferson, Three Sisters \& Mt. Washington. Forest Service policy dictates that geothermal leases will not be issued for lands in Wilderness classification. Leasing in areas removed from Wilderness will not take place until the final environmental impact statement has been approved. 
SITE LOCATION AND PHYSICAL DESCRIPTION

SITE: BELKNAP-FOLEY HOT SPRINGS KGRA

..Latitude: 44011 ' 6" $\mathrm{N}$

..Longitude: $122^{\circ} 3^{\prime} 2^{\prime \prime} \mathrm{W}$

..Rectilinear: Secs. $14,30-23,26,28,29$, T.16S., R.6E., W.M.

..County: Lane

..Adjacent Counties: Linn, Jefferson, Deschutes, Klamath, Douglas

..Maps: U.S.G.S.Topographic - McKenize Bridge - 1:62,500

AMS - Salem, Oregon - 1:250,000

..Topography

Located in the Western Cascades, the Belknap-Foley KGRA is in rugged forested land. Elevations range from $485 \mathrm{~m}$. $(1,591 \mathrm{ft}$. in the McKenize River Valley to $1,097 \mathrm{~m}$. $(3,600 \mathrm{ft}$.) at the southern boundary of the KGRA. Adjacent $0^{\prime}$ Leary Mountain reaches an elevation of $1,725 \mathrm{~m} .(5,660 \mathrm{ft}$.$) . Stream discharge$ is into the McKenzie River system.

...Present Land Use:

Primarily timber production and recreational uses managed by the Willamette National Forest.

..Future Land Use Plans:

It is anticipated that logging and forest management activities, and recreation will continue to be the prime focus.

... Aesthetics:

The area's natural beauty and proximity to three Wilderness Areas, the H. J. Andrews Experimental Forest, and 01 all ie Research Natural Area represent high aesthetic values. 
..Historical/Archaeological Signifiance:

A check of the Federal Register, Vol. 41, No. 28, February 10, 1976, pages 6008 and 6009 and subsequent Federal Registers through Vol. 41, No. 121 has shown that no sites or structures within the area are listed on, or nominated for, the National Register of Historical Places, al though the Willamette Valley and Cascade Mountain Wagon Road has been recommended for nomination. (32)

Fish Lake is of considerable historical interest. It was a rest stop for travelers along the Willamette Valley and Cascade Mounta in Wagon Road, and later it was the site of a forest service remount and fire station.

Belknap Hot Springs was discovered in 1859 and homesteaded by R. S. Belknap in 1869. Foley Springs, discovered by William Hanley and William Vick, was developed for public use in 1870 by Dr. Abram A. Foley. Both resorts flourished during the heyday of hot spring resorts in the early 20th century. 
GEOLOGICAL/GEOPHYSICAL DESCRIPTION

SITE: BELKNAP-FOLEY HOT SPRINGS KGRA

..Geologic Description:

Bedrock is Pliocene to Holocene basic volcanic flows and pyroclastic rocks.

Both hot springs discharge from volcanic breccia facies of the Western Cascade Group.

Baldwin (1964) suggests the alignment of Belknap, Foley, McCredie and Kitson hot springs may indicate a north trending fault similiar to the Callaghan and Buddington (1938) suggested fault extending the length of the Cascades with the east side downdropped. (20)

- Geologic Hazards:

Seismic intensity levels are low.

Hazards include landslides, erosion, and flooding.

.. Hydrology

\section{Ground Water}

The volcanic rocks of the High Cascades which occur in much of the area are generally considered to be highly fractured.

Meteoric water readily infiltrates these formations and

discharges freely to maintain the dry weather flow of streams. In most places, water lies at depths exceeding $100 \mathrm{ft}$.

reflecting the high permeability of the underlying rock and the depth of surface erosion.

The alluvium along the McKenzie River and Horse Creek and glacial deposits adjacent to local stream valleys consists of unconsolidated, poorly stratified and lenticular beds. Where these deposits have sufficient thickness, they may contain ground water that could be used locally for domestic purposes.

The older volcanic rocks of the Western Cascades are present in parts of the area, mostly west of the McKenzie River. The older rocks aiso underlie the High Cascade volcanics in the contact zone between the two geologic provinces. Belknap Hot Springs issue from conglomerate lying near upper Tertiary lavas while Foley Hot Springs issue from Sardine volcanics of mid-Miocene to late Miocene age. Little is known of the subsurface characteristics of formations supporting these springs. However, it has been conjectured that they may be associated with a highly fractured zone or a layer of high permeability. 
The only ground water developments in the area are wells at Vail Bridge Campground and Coldwater Cove Campground. The yield of these wells ranges up to $20 \mathrm{gpm}$.

The only data available on ground water quality in the area is the analysis of water from Belknap Hot Spring. That water may rise from considerable depth, so is probably not representative of water from shallow aquifers. Water from zones likely to be tapped by wells should be similar to water from streams, but somewhat higher in dissolved constituents. The ground water should be of excellent quality suitable for domestic and other purposes. Steep gradients, high volume of water and periodic floods combine to keep the area's stream beds well scoured. This condition along with the paucity of potassium and phosphorous in underlying rock has resulted in development of streams of low fetility and fish production potential.

\section{Surface Water}

The area is drained by the Mckenzie River system. Among the larger tributary streams are Horse Creek, White Branch, Lost Creek, Deer Creek, Smith River and Parks Creek. Unique features of the area's hydrology are Fish and Lava Lakes, which are full through the winter and early summer months, but recede through lava tubes and fissures during the later dry summer months.

Average discharge of the McKenzie River at the Clear Lake outlet (30 yr. average; June 1912-Sept. 1915, and 0ct. 1947 to 1974) is 483 cubic $\mathrm{ft} . / \mathrm{sec}$. (cfs) and 349,900 acres feet per year. At the gaging station below Trail Bridge Dam the average yearly discharge (15 year period, 0ct. 1959 to 1974) is 1,070 cfs and 775,200 acre feet, adjusted for storage.

Average temperatures of the McKenzie River at the McKenzie Bridge gaging station is $45.5^{\circ} \mathrm{F}$, with a minimum of $41^{\circ} \mathrm{F}$ and a maximum of $51.80 \mathrm{~F}$. Temperatures measured at this station are the lowest in the Mckenzie system. Low temperatures are attributable to the subterranean reservoirs, snow melt and glacial seepages comprising the sources for this section of the river. 


\section{RESERVOIR CHARACTERISTICS}

\section{SITE: BELKNAP-FOLEY HOT SPRINGS KGRA}

.Reservoir Temperature

..Surface: $71^{\circ} \mathrm{C}$ (date sampled $1 / 75$ )

$8^{\circ} \mathrm{C}$ (date sampled $6 / 76$ )

..Subsurface: $140^{\circ} \mathrm{C}$

..Geochemical: Belknap Hot Springs

$\begin{array}{ll}\text { Silica conductive: } 135^{\circ} \mathrm{C} & \text { Silica Adibatic: } 131^{\circ} \mathrm{C} \\ \mathrm{Na}-\mathrm{K}-1 / 3 \mathrm{Ca} \text {. } 114^{\circ} \mathrm{C} & \mathrm{Na}-\mathrm{K}-4 / 3 \mathrm{Ca}: 82^{\circ} \mathrm{C}\end{array}$

..Flow Rates: Belknap Hot Springs - $300 \mathrm{lpm}$,

$$
\text { Foley Hot Springs - } 95 \mathrm{lpm}
$$

..pH: 7.62 (Belknap)

..Total Dissolved Solids: 2,506 ppm (Belknap Hot Springs)

..Fluid Chemistry:

COUGAR

(Approx. $25 \mathrm{~km}$. from

Hot Springs:

Temperature

$\mathrm{pH}$

Specific conductance (micromhos)

Silica

Calcium

Magnesium

Sodium

Potassium

Lithium

Bicarbonate

Carbonate

Chloride

Flouride

Boron

Sulfate

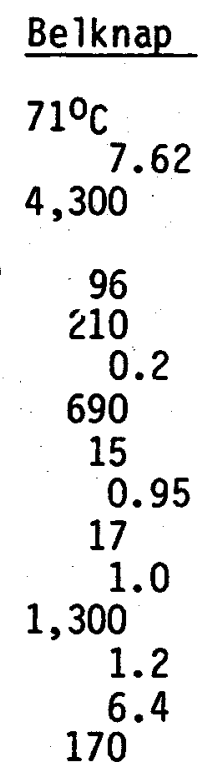

Foley $78^{\circ} \mathrm{C}$ $4,800^{8}$

60

494

0.8

475

11.2

0.96

1,304

0.8

10.2

550
Belknap Hot Springs)

$44^{\circ} \mathrm{C}$

7.76

2,890

\section{0}

225

0.1

(Units $\mathrm{mg} / \mathrm{l}$ )

392

6.3
0.52
19
1
788

0.8
5.1
260

(8) (19) 
..Estimated Reservoir Heat Content: $\quad .2 \times 10^{18}$ cal.

..Subsurface Area of Reservoir: $1.5 \mathrm{~km}^{2}$ estimated

..Hot Springs Location: Belknap - Sec. 11, T.16S., R.6E.

Foley - Sec. 28, T.16S., R.6E.

Cougar - Sec. 7, T.17S., R.5E. 


\section{LAND OWNERSHIP AND LEASING}

SITE: BELKNAP-FOLEY SPRINGS KGRA

..Land Ownership - Primarily-Willamette National Forest Total Area (Acres) - 5,066 KGRA

.. Land Leased - none

.. Tentative Lease Sale Dates: September 27, 1979

.. Summary of Leasing Status and Needs:

Leasing activity awaits the completion of the Willamette National Forest's Environmental Impact Statement for geothermal leasing in the Belknap-Foley area. 


\section{GEOTHERMAL DEVELOPMENT STATUS}

\section{SITE: BELKNAP-FOLEY HOT SPRINGS KGRA}

..Present Development Status:

Belknap Hot Spring Resort offers a warm swimming pool and overnight accommodations.

The Oregon Department of Geology and Mineral Industries drilled two temperature gradient wells in the area. Data from these tests are listed on the following pages.

..Projected or Planned Development:

Belknap Hot Springs Resort plans to expand during late 1978 to include a new pool and tubs. The lodge is to be refurbished and year-round use is expected. 
Location: Sec. 27 NWP $N_{4} W_{\frac{4}{4}}$, W.M., T.16S., R.6E.

Map Reference: AMS Salem, Oregon

Date Measured: 9/29/76



Average gradient $10-150$ meters $-92.6^{\circ} \mathrm{C} / \mathrm{km}$ 


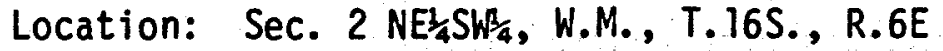

Map Reference: AMS Salem, Oregon

Date Measured: 9/29/76

\begin{tabular}{|c|c|c|c|c|c|}
\hline $\begin{array}{l}\text { DEPTH } \\
\text { METERS } \\
\end{array}$ & $\begin{array}{l}\text { DEPTH } \\
\text { FEET } \\
\end{array}$ & $\begin{array}{l}\text { TEMPE } \\
\text { DEG C } \\
\end{array}$ & $\begin{array}{l}\text { TURE } \\
\text { DEG F }\end{array}$ & $\begin{array}{r}\text { GEOTHER } \\
\text { DEG C/KM } \\
\end{array}$ & $\begin{array}{l}\text { AL GRADIENT } \\
\text { DEG F/100 FT }\end{array}$ \\
\hline $\begin{array}{l}5.0 \\
10.0 \\
15.0 \\
20.0 \\
25.0 \\
30.00 \\
35.0 \\
40.0 \\
45.0 \\
50.0 \\
55.0 \\
60.0 \\
65.0 \\
70.0 \\
75.0 \\
80.0 \\
85.0 \\
90.0 \\
95.0 \\
100.0 \\
105.0 \\
110.0 \\
115.0 \\
120.0 \\
125.0 \\
130.0 \\
135.0 \\
140.0 \\
145.0 \\
150.0\end{array}$ & $\begin{array}{l}16.4 \\
32.8 \\
49.2 \\
65.6 \\
82.0 \\
98.4 \\
114.8 \\
131.2 \\
147.6 \\
164.0 \\
180.4 \\
196.8 \\
213.2 \\
229.6 \\
246.0 \\
262.4 \\
278.8 \\
295.2 \\
311.6 \\
328.0 \\
344.4 \\
360.8 \\
377.2 \\
393.6 \\
410.0 \\
426.4 \\
442.8 \\
459.2 \\
475.6 \\
492.0\end{array}$ & $\begin{array}{l}7.600 \\
7.270 \\
7.470 \\
7.440 \\
7.550 \\
7.690 \\
7.900 \\
7.990 \\
8.150 \\
8.260 \\
8.440 \\
8.690 \\
8.820 \\
9.080 \\
9.280 \\
9.540 \\
9.740 \\
10.210 \\
10.500 \\
10.810 \\
11.080 \\
11.450 \\
11.810 \\
12.130 \\
12.630 \\
13.040 \\
13.600 \\
14.110 \\
14.500 \\
14.810\end{array}$ & $\begin{array}{l}45.68 \\
45.09 \\
45.45 \\
45.39 \\
45.59 \\
45.84 \\
46.22 \\
46.38 \\
46.67 \\
46.87 \\
47.19 \\
47.64 \\
47.88 \\
48.34 \\
48.70 \\
49.17 \\
49.53 \\
50.38 \\
50.90 \\
51.46 \\
51.94 \\
52.61 \\
53.26 \\
53.83 \\
54.73 \\
55.47 \\
56.48 \\
57.40 \\
58.10 \\
58.66\end{array}$ & $\begin{array}{r}.0 \\
-66.0 \\
40.0 \\
6.0 \\
22.0 \\
28.0 \\
42.0 \\
18.0 \\
32.0 \\
22.0 \\
36.0 \\
50.0 \\
26.0 \\
52.0 \\
40.0 \\
52.0 \\
40.0 \\
94.0 \\
58.0 \\
62.0 \\
54.0 \\
74.0 \\
72.0 \\
64.0 \\
100.0 \\
82.0 \\
112.0 \\
102.0 \\
78.0 \\
62.0\end{array}$ & $\begin{array}{r}.0 \\
-3.6 \\
2.2 \\
-\quad .3 \\
1.2 \\
1.5 \\
2.3 \\
1.0 \\
1.8 \\
1.2 \\
2.0 \\
2.7 \\
1.4 \\
2.9 \\
2.2 \\
2.9 \\
2.2 \\
5.2 \\
3.2 \\
3.4 \\
3.0 \\
4.1 \\
4.0 \\
3.5 \\
5.5 \\
4.5 \\
6.1 \\
5.6 \\
4.3 \\
3.4\end{array}$ \\
\hline
\end{tabular}

Average gradient $10-150$ meters $-49.7^{\circ} \mathrm{C} / \mathrm{km}$ 


\section{INSTITUTIONAL CONSIDERATIONS}

\section{SITE: BELKNAP-FOLEY HOT SPRINGS KGRA}

.. Institutional Requirements:

Completion of environmental review by the Forest Service before any leasing can take place.

..Agency and Public Attitudes:

Geothermal exploration or development is likely to draw criticism from Eugene based environmental organizations.

Public is sensitive to any geothermal development in the Cascade Range.

.. Status of Requirements (i.e., EIA/EIS Requirements):

A draft environmental impact statement addressing.geothermal leasing is scheduled for release in mid 1979 with the final to follow by late 1979 .

Leasing could not be considered until late 1979.

The draft environmental statement will address geothermal leasing for a 151,903 acre area which includes KGRA land, non-competitive lease application lands and other National Forest lands. 


\section{Land Classification}

Borders 3 Wi Iderness Areas - Mt. Jefferson, Three Sisters, and Mt. Washington.

"The Geothermal Stream Act does not exclude Wilderness Areas from the leasing program. As a matter of policy, however, the Forest Service does not issue geothermal leases for Wilderness Areas because of the basic incompatibility of development activities with the Wilderness concept."

Geothermal lease applications filed in 1973 overlapped approximately 1,000 acres of the Mt. Washington Wilderness Area in T.14S, R.7E, Sections 16, 21, 28 and 33; and T.16S, R.7E, Sections 2 and 3 .

Since that time, applications have been withdrawn on approximately 440 acres. leaving approx. 560 acres of Wilderness still covered by lease applications. Applications also cover approximately 700 acres of the Three Sisters Wilderness in T.16S, R.7E, Sections 12, 14 and 23. The lease applications for lands in Section 23 have been formally rejected. (32)

\section{Roadless Areas}

Approximately 4,100 acres have been selected for study.

\section{Research Natural Areas}

120 acres of $01 a 11$ ie Ridge Research Natural Area are included in the EIS study area, although lease applications have been withdraw.

\section{1d Growth Groves}

Two areas totalling approximately 160 acres are designated as old growth groves.

Fish Lake Creek grove lies between Highway 126 and Fish Lake Creek, 1/2 mile north of Clear Lake. Lost Creek grove is situated located at the confluence of White Branch with Lost Creek. 
SITE: BELKNAP-FOLEY HOT SPRINGS KGRA

-.CLIMATE - Weather station is located at Belknap Hot Springs ..Prevailing Winds: Varying from southwest to northwest ..Precipitation (Annual): $193 \mathrm{~cm}$. ..Degree Days (Annual): 4,739 at Eugene (number of degree days at the site would be above this figure)

. Relative Humidity (Seasonal Peaks)

Summer: $40-50$ percent

Winter: $70-90$ percent

..AIR QUALITY:

There are no measuring stations in the area. Quality is generally excellent with the major sources of pollution being: dust from unpaved roads, vehicle exhaust emissions, and smoke from slash burning. Field burning in the Willamette Valley contributes smoke during late July, August and September.

.WATER QUALITY: Generally excellent.

.. NOISE: Noise levels are low.

. BIOLOGICAL

..Dominant Flora: Douglas-Fir forest.

Principal associates: Douglas-fir (Pseudotsuga menziesii) Western hemlock (Tsuga he terophyl7a) Western redcedar (Thuja plicata)

Above $914 \mathrm{~m} .(3,000 \mathrm{ft}$.$) the True-fir-Mountain hemlock$ forest association predominates. 
..Dominant Fauna:

Black-tailed deer, Roosevelt elk, black bear, coyote, cougar, raptorial birds, beaver, songbirds and others. Streams in the area have low fish productivity. Sport fishing is supported by the Oregon Fish and Wildlife stocking program.

..Endangered Species

Flora: Rare, threatened and endangered plants that are known to occur in the west central Cascades and may be in the area:

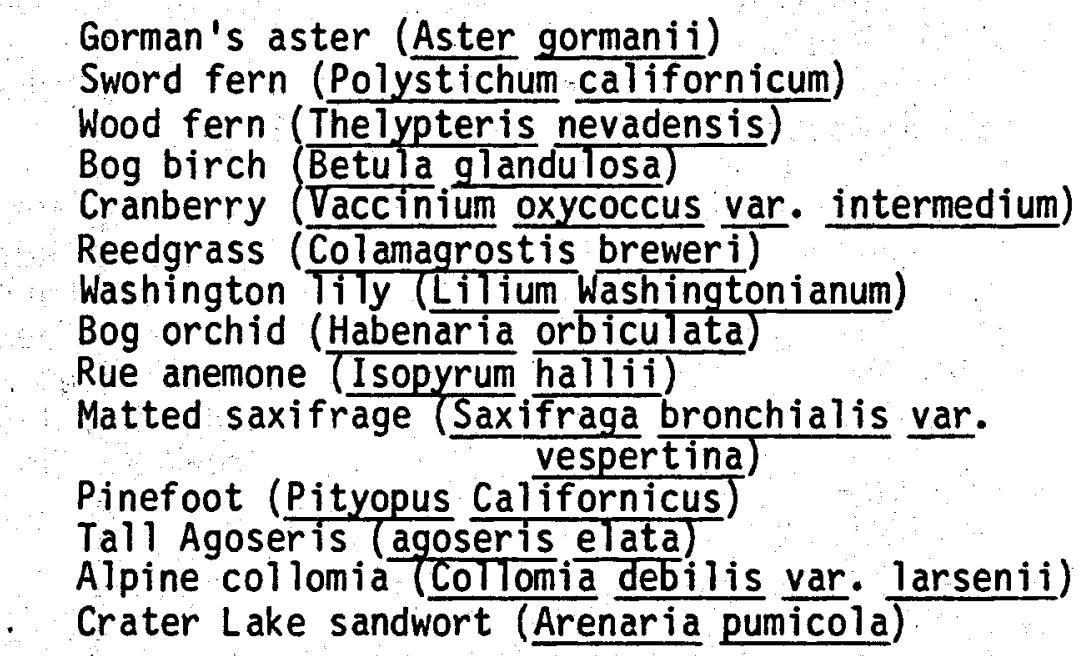

Fauna:

Endangered Species:

American peregrine falcon (Falco peregrinus anatum) no known nesting sites, but migrants may fly over or rest in area.

Arctic peregrine falcon (Faico perearinus tundrius) may migrate over and rest in area.

Threatened species:

Wolverine (Gulo luscus) - probably present only. on an occasional basis

Northern bald eagle (Haliacetus leucorephalus alacarus) occasionally sighted at Clear, Fish \& Lost Lakes during nesting season.

Northern spotted owl - (Strix occidentalis caurira) reported sitings at $F$ ish Lake and other points in the area. 
TRANSPORTATION AND UTILITIES

SITE: BELKNAP-FOLEY HOT SPRINGS KGRA

.. Electric Transmission Lines

Eugene Water and Electric Board (EWEB) - $115 \mathrm{kv}$ line

$\therefore$ Road Servicing the Area

State Route 126

U.S. Route 20

State Route 242

(impassible in winter)

State Route 22 in KGRA

$29 \mathrm{~km}$. (18 mi.) from Belknap Springs

$5 \mathrm{~km}$. (3.5 mi.) from Belknap Springs $35 \mathrm{~km}$. (22 mi.)

National Forest Service Roads: Lava Lake Rd. 1349, Hack leman Rd. 1360, Robinson Lake Rd. 1467 , 01allie Creek Rd. 1573, Scott Creek Rd. 1601, Foley Ridge Rd. 169, and Horse Creek Rd. 161.

.. Other Utilities or Rights-of-Way

Lane Electric Company - powerline - 8.75 miles in T.16S., R.6E. Oregon State Board of Aeronautics - air strip in Section 16, T.16S., R.6E.

Pacific NW Bell - electronic site - .25 acre in Section 1, T.15S., R.6E. and Section 11, T.16S., R.6E.

E. H. Stär - spring - $150 \mathrm{ft}$. right-of-way in Sec. 11, T.16S., R.6E.

Oregon State Highway Department - storage years:

approximately 4 acres in Sec. 2, T.16S., R.6E. less than 3

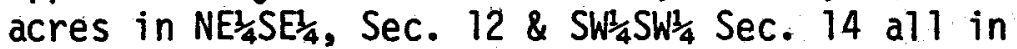

T.16S., R.7E.

approximately $\frac{1}{4}$ acre in Sec. 14 T.16S., R.6E.

In addition, 10 road right-of-ways have been granted to various agencies, companies and individuals (exact location not known).

No grazing allotments in area. 
POPULATION

SITE: BELKNAP-FOLEY HOT SPRINGS KGRA

..General Description of Population ,

Population density is low and is concentrated on private land at the hot springs, White Branch, Mckenzie Bridge, Rainbow and Blue River.

The population increases seasonally when summer homes are in use.

Others in the area are on a non-residency basis. They include recreationists, tourists, and timber and Forest Service emp loyees.

Population Centers

McKenzie Bridge

Sisters

Bend

Eugene
Distance

$9.5 \mathrm{~km}(6 \mathrm{mi}$.) from Belknap

$6.0 \mathrm{~km}$ (3.8 mi.) from Foley Blue River $16.6 \mathrm{~km}(10.5 \mathrm{mi}$.$) from Belknap$

$59 \mathrm{~km}$ ( $37 \mathrm{mi}$.

$86 \mathrm{~km}(54 \mathrm{mi}$.

$94.4 \mathrm{~km}$ ( $59 \mathrm{mi}$.

...Economics

Present Land Use: Timber production and recreational uses.

..Future Land Use:

Continued focus on timber resource and recreational activities.

\section{Recreation}

Recreation plays a key role in the economy of the upper Mckenzie River Valley.

Well-known attractions:

Clear Lake - 142 acre natural, crystal clear lake regarded as the source of the McKenzie River. Motor boating prohibited. Very popular trout fishing spot. 
Waterfalls - Sahalie, Kassah, Tamolitch and Proxy Falls. All except Tamolitch are accessible via short traits.

McKenzie River - "nationally renowned trout stream"

Carmen-Smith Project Reservoirs - components of 90 megawatts EWEB hydroelectric project.

Seasonal Lakes - Lava, Fish and Lost Lakes

Dispersed recreation areas:

Dispersed motorized recreation/timber:

Approximately 12,200 acres in Clear Lake - Sand Mountain. Nash Crater area is included in a designated area. totalling 15,589 acres.

Dispersed non-motorized recreation/timber:

Approximately 200 acres in Highway 20-22 junction area and 1,200 acres in Two Butte-Melakwa Lake areas have been designated non-motorized dispersed areas.

English Mountain undeveloped Roadless area:

Approximately 680 acres east of Challie Trail between Horsepasture Mountain and Taylor Castle.

Special interest areas:

Approximately 120 acres of 390 acre Lamb Butte Scenic Area falls within the EIS study area.

Additional 840 acres along the Mckenzie River in Tamolitch

Falls - Beaver Marsh area have been designated for

classification as a special iriterest area.

23 deve?oped recreation sites (EIS area)

30 inventoried potential sites

8 trails with total length of approximately 18.7 miles are within study area

1976 - 143,700 visitor days at developed recreation sites. Dispersed recreation area usage in 1976 - approximately 50,000 visitor days - fishing, hiking, riding, water sports and enjoyment of scenery, cross-country skiing, and snowmobiling. 
SITE: MCCREDIE HOT SPRINGS KGRA OREGON 


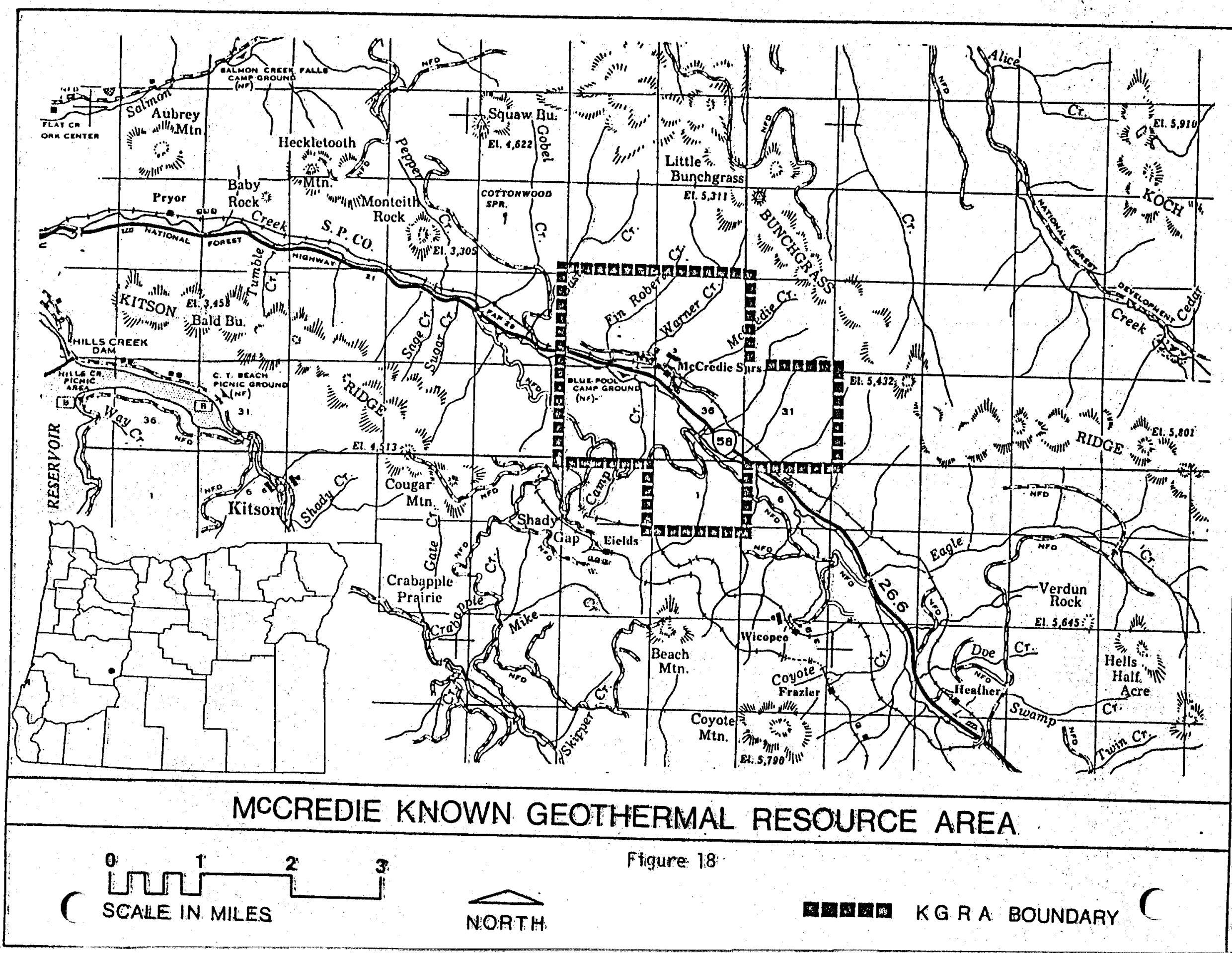




\section{CREDIE HOT SPRINGS KGRA}

McCredie Hot Springs is situated of the southern extension of the Western Cascades hot springs belt. Located primarily in T.2 IS., R.4E., W.M., in Lane County the KGRA covers 3,659 acres. Oakridge, a nearby lumber-based town is 14.5 kilometers northeast of the hot springs.

Use of natural resources for timber production and recreation dominates present land use and is expected to remain the focus in future plans. The Willamette National Forest is responsible for managing the KGRA and surrounding lands, all of which ore in federal ownership.

The reservoir characteristics of McCredie hot springs appear technically promising for geothermal development. The springs flow $76 \mathrm{lpm}$ of $73^{\circ} \mathrm{C}$ water. Geochemical thermometers suggest that a $120^{\circ} \mathrm{C}$ resource is feasible at depth. A hot-water-dominated hydrothermal convection system, similiar to those postulated for the other Cascade hot springs areas, seems to be indicated at McCredie.

The most realistic proposed use of the McCredie resource would be for lumber drying or processing of wood chips in Oakridge and Westfir, and district heating in Oakridge. A $20 \mathrm{~km}$ pipeline long, would be required to deliver hot water to Westfir, and would have to be available at a cost less than conventional fuels. An industrial customer would make a district heating system for Oakridge a reasonable consideration. The area is well suited for commercial greenhouse operations for growing bedding plants and tree seedlings. Otherwise non-electrical uses of the McCredie geothermal resource would be limited by the lack of population at the site.

The benefits of McCredie's thermal waters have been enjoyed since 1916 when Judge William McCredie built a resort offering mineral baths and hotel facilities. The \$pa operated until 1958 when the main building burned. There are no structures at the site now, but the hot springs are used by "roadside" bathers. West of McCredie, Kitson Hot Springs are maintained as a Boy Scout camp. 
Beyond the limited present uses of the hot springs, only moderate interest has been expressed in developing the MicCredie geothermal resources. Available information indicates that private industry has not undertaken any exploration. Non-competitive lease applications have been filed in areas around the KGRA, but as with competitive leases, cannot be processed until the Forest Service issues the McCredie Geothermal Area Environmental Impact Statement. At best, the document can be expected in late 1979. When land positions have been established by leasing, exploration and development activities should increase.

Further possible restrictions to development include the environmental and land use concems common to all the Known Geothermal Resource Areas in the Cascade Region. 
SITE DATA SUMMARY

SITE: MC CREDIE HOT SPRINGS KGRA

..Physical Reservoir Data

. Temperature ${ }^{\circ} \mathrm{C}$

Surface: $73^{\circ} \mathrm{C} \quad$ Subsurface: $160^{\circ} \mathrm{C}$

.. Site Land Status: The KGRA is in federal ownership managed by the Willamette National Forest.

Total KGRA Acres: 3,659 - Federal

Total Acres Leased: 0 - Federal

..Geothermal Development Status:

No present development.

Two wells have been measured for temperature gradients.

..Local and State Attitude Toward Geothermal Development:

Sensitive due to environmental considerations.

Locals appear to favor development that would enhance the economy of the area.

..Land Use and Population:

There are few permanent residents.

Recreationists, logging industry employees and Forest Service personne 1 are in the area on a transitory basis.

The Kitson Hot Spring area is used as a Boy Scout camp.

.. Comments and Critical Issues:

The area is within $22 \mathrm{~km}$ of the Diamond Peak Wilderness Area. Competitive and non-competitive leasing will not be considered until the McCredie Geothermal Area Environmental Impact Statement has been completed and approved by the U.S. Forest Service. 
SITE LOCATION AND PHYSICAL DESCRIPTION

SITE: MC CREDIE HOT SPRINGS KGRA

.. Latitude: $43^{\circ} 42^{\prime} 6^{\prime \prime} \mathrm{N}$

..Longitude: $122^{\circ} 17^{\prime} 3^{\prime \prime} \mathrm{W}$

..Rectilinear: Secs. $25,26,35,36$, W.M., T.21S., R.4E.; Sec. 1, T.22S., R.4E.; Sec. 31, W.M., T.21S., R. $5 E$.

.County: Lane

..Adjacent Counties: Deschutes, Klamath, Douglas, Lincoln, Benton, Linn.

..Map Reference: U.S.G.S. Topographic Oakridge, Oregon 1:62,500

. Topography

Rugged forested land in the Western Cascades. Elevations range from approximately $579 \mathrm{~m}$. (1,900 ft.) along Salt Creek 8,829 $\mathrm{m}$. $(6,000 \mathrm{ft.})$ on Bunchgrass Ridge.

..Present Land Use:

National forest land used for timber production and recreation. ..Future Land Use Plans:

Increased timber yield and recreational opportunities. .. Nesthetics: High aesthetic value.

McCredie Hot Springs is within approximately $22 \mathrm{~km}$ (13.5 miles) of the Diamond Peak Wilderness Area. 
..Historical/Archaeological Significance:

Archaeological investigations are being conducted in conjunction with the Environmental Impact Statement.

The Calapooya Indians lived in the Middle Fork Willamette Valley in small groups of about 20 persons. Molalla and $K$ lamath Indians also used the area to some extent. In 1855 the Willamette River area was ceded to the U.S. by the Kalapuyans who then moved to the Grand Ronde Reservation.

The Southern Pacific Railroad line was completed into Oakridge in 1912, but was not completed through the geothermal area and over Willamette Pass until 1926. A special use permit for a ten acre parcel in the McCredie hot springs area (then known as Winino H.S.) was issued in 1906. In 1916 Judge William W. McCredie purchased an interest in the site and bujlt a hotel resort that operated until the main structure burned to the ground in 1958. Currently there are no structures at the site.

... Hydrology:

Drainage

Waters of the area drain into Salt Creek, Salmon Creek and Hills Creek - all tributaries of the Middle Fork of the Willamette River.

\section{Discharge}

Average discharge of the Middle Fork Willamette River at the U.S.G.S. gaging station 4.2 mi les downstream from the North Fork (52 year average) is 2,779 cubic feet seconds (cfs), or 2,013,000 acre-feet per year. Average discharge of the Middle Fork Willamette 0.4 mile above Salt Creek ( 40 year average) is $1,161 \mathrm{cfs}$ or 841,000 acre-feet per year. No gaging station exists along the Middle Fork between the Salmon Creek and North Fork conluences. 
Temperature

Temperature records from the gaging station on the Middle Fork Willamette River below the North Fork confluence (Sept. 1950 to October 1960 and June 1961 to September 1974) range from $74^{\circ} \mathrm{F}$ to the freezing point. At the gaging station above the Salt Creek confluence temperatures, recorded between October 1960 and September 1974 range from a maximum of $770^{\circ} \mathrm{F}$ to a minimum of $350 \mathrm{~F}$.

Domestic Use

Domestic water sources - B lue Pool Campground, Salt Creek Recreation residence sites and the City of Oakridge. 


\section{RESERVOIR CHARACTERISTICS \\ SITE: MC CREDIE HOT SPRINGS KGRA}

..Reservoir Temperature

.. Surface: $73^{\circ} \mathrm{C}$

. Subsurface: $1600^{\circ} \mathrm{C}$

..Geochemical

$$
\begin{aligned}
\mathrm{SiO}_{2}: & 120{ }^{\circ} \mathrm{C} \\
\mathrm{Na}-\mathrm{K}-\mathrm{Ca}: & 75^{\circ} \mathrm{C}
\end{aligned}
$$

..Flow Rates: $76 \mathrm{lpm}$

..pH: 7.29

..Fluid Chemistry:

Chemical constituents are higher than other hot springs in the Western Cascades. A hot-water-dominated hydrothermal convection system is indicated.

McCredie

Hot Springs

(units $\mathrm{mg} / \mathrm{l}$ )

Temperature

$\mathrm{pH}$

Specific Conductance (micromhos)

Silica

Calcium

Magnes ium

Sodium

Potassium

Lithium

Bicarbonate

Sulfate

Chloride

Fluoride

Boron

Total dissolved solids
$7^{7} \mathrm{C}$ 7.29

6,730

79

460

0.9

1,000

22

1.4

21

240

2,200

2.7

18

\author{
Kitson \\ Hot Springs \\ (units ppm)

$$
44^{\circ} \mathrm{C}
$$$$
7.4
$$

10,500

47

626

$1,5.7$
28
28
$27^{\circ}$

197

3,420

2.8

25

$6,340 \mathrm{ppm}$

(8)

.. Hot Springs Location:

McCredie Sec. 36, NW/4, W.M., T.21S, R.4E.

Kitson Sec. 6, W.M., T.22S., R.4E. 
LAND OWNERSHIP AND LEASING

SITE: MC CREDIE HOT SPRINGS KGRA

..Land Ownership: Willamette National Forest

Total Area (Acres) - 3,659

Federal (Acres) $\quad-3,659$

..Land Leased: 0

..Tentative Lease Sale Dates: October 23, 1980

..Sumary of Leasing Status and Needs:

Leasing activity awaits completion of the McCredie Geothermal Area Environmental Impact Statement. 
GEOTHERMAL DEVELOPMENT STATUS

SITE: MC CREDIE HOT SPRINGS KGRA

..Present Development Status:

No development.

Temperature gradients have been measured in two wells in the Mccredie area. Data is present below:

Location: Sec. 28 SE $\frac{1}{4} N E \frac{1}{4}$, W.M., T.21S., R.4E.

Map Reference: AMS Roseburg, Oregon

Date Measured: $9 / 29 / 76$

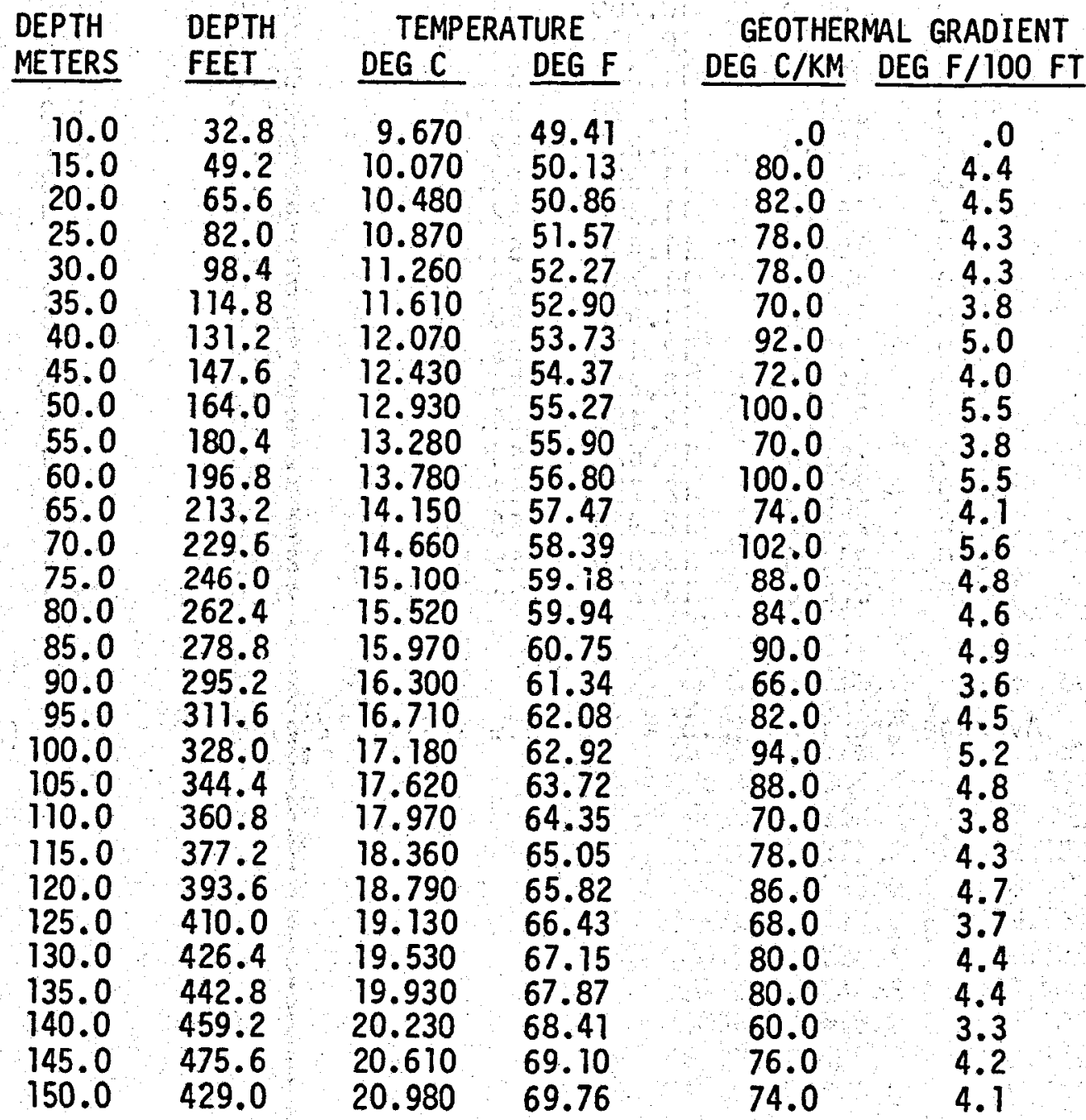

Average gradient $15-150$ meters $-80.8^{\circ} \mathrm{C} / \mathrm{km}$ 


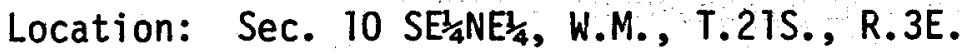

Map Reference: AMS Roseburg, Oregon

Date Measured: 9/28/76

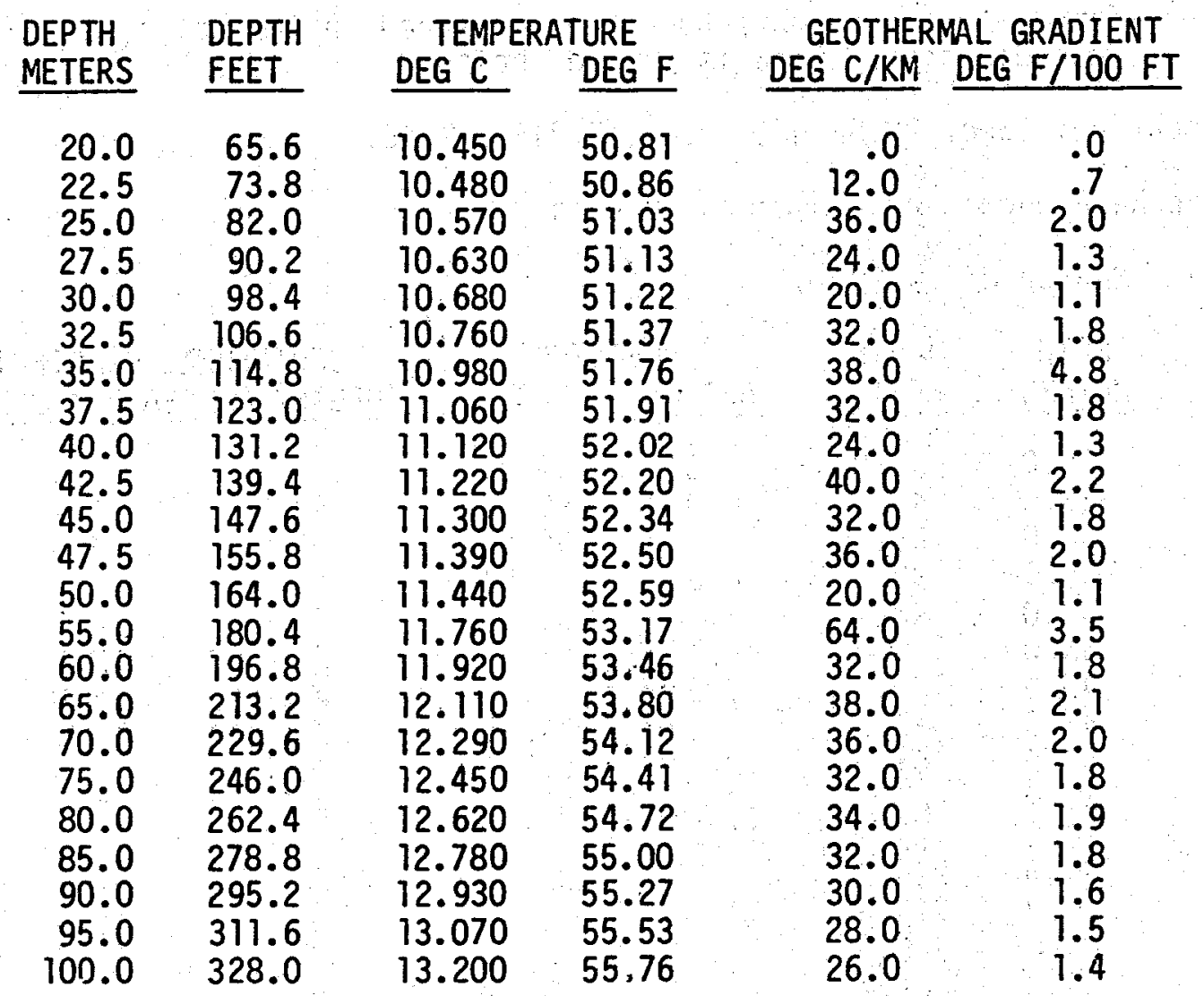

Average gradient $22.5-100$ meters $-31.72^{\circ} \mathrm{c} / \mathrm{km}$ 
INSTITUTIONAL CONSIDERATIONS

SITE: MC CREDIE HOT SPRINGS KGRA.

..Institutional Requirements:

Approved leasing by the Forest Service is needed before exploration and development can occur.

RARE II land use decisions may effect geothermal activities in the McCredie area.

Several areas in the vicinity of the McCredie KGRA are being examined by the U.S. Forest Service as part of the RARE II process. As a result of the review, the following designations are possible:

Recommend for inclusion in the National Wilderness

Preservation System, recomiend for further study, return to multiple-use status.

According to the Forest Service classification, none of the areas has producing proven or possible geothermal resources.

The areas are as follows:

\begin{tabular}{ccccc} 
Area & Area Code & Forest Acreage & $\begin{array}{c}\text { Willamette National } \\
\text { Forest Acreage }\end{array}$ \\
\hline Waldo & 6106 & 9,700 & 97,176 \\
Charlton & 6107 & 9,280 & 2,320 \\
Maiden Park & 6108 & 29,420 & 10,080 \\
Odell & 6111 & 14,150 &
\end{tabular}


..Agency and Public Attitudes:

Environmental concerns about geothermal development in the Western Cascades results in sensitive public attitudes.

..Status of Requirements (i.e., EIA/EIS Requirements):

An Environmental Impact Statement considering geothermal leasing is being prepared by the Willamette National Forest. The EIS will cover the KGRA and surround areas for a total study are of 19,603 acres.

Optimistically the EIS can be expected in late 1979. 


\section{ENVIRONMENTAL FACTORS}

\section{SITE: MC CREDIE HOT SPRINGS KGRA}

\section{..CLIMATE:}

Climate is strongly influenced by moist, marine air flowing off the Pacific Ocean. Temperature inversions are not uncommon. No weather stations are maintained in the area.

...Prevailing Winds:

Varying from southwest to nor thwest.

..Precipitation (Annual): $127 \mathrm{~cm}$.

-. Average Temperature

Minimum: $330^{\mathrm{F}}$

Maximum: $64^{\circ} \mathrm{F}$

..Relative Humidity (Seasonal Peaks)

Sumner: $40-50$ percent

Winter: $70-90$ percent

\section{..AIR QUALITY:}

Generally excellent because of the are's remoteness from urban areas. Precise analytical data is lacking because there are no sampling stations in the area. Principal sources of air pollution are dust from traffic on unpaved roads, smoke from burning logging slash, and field burning in the Willamette. Valley.

..WATER QUALITY: Generally excellent.

..NOISE: Low levels.

..BIOLOGICAL

..Dominant Flora:

Douglas fir Forest - is the principal type covering approximately 19,200 acres, 97 percent of the lands in the EIS study area. Although timber harvest has been underway for many years, extensive stands of old growth Douglas fir still remain. 
Western hemlock (Tsuga heterophylla), Pacific silver-fir (Abies amabilis), and western redcedar (Thuja plicata) are the principal associates of Douglas fir Pseudotsuga menziesii) in this forest community.

Shrubs common to the Douglas fir types are Pacific rhododendron (Rhododendron macrophyllum), vine maple (Acer circinatum), golden chingapin (Castanops is chrysophylla) and Pacific dogwood (Cornus nuttalii).

Among the more commonly seen forbs are sword fern (Polystichum munitum), deerfoot vanilla leaf (Achlys triphylla), tall Oregon grape (Berberis nervosa), queencup beadlily (Clintania uniflora) and white inside-out-flower (Vancouveria hexandra).

The remaining 3 percent of the EIS study area includes non-commerical rocky forest lands, meadows and water.

Common shrubs include Pacific serviceberry (Amelanchier florida), thimbleberry (Rubus parviflorus) and huck leberry (Vaccinium sp.)

..Dominant Fauna:

Roosevelt elk, black bear, black-tailed deer, beaver, rodents, coyote, raptorial birds and others.

The area covers a variety of wild ife habitats including old growth forests, brushy cutover areas, meadows, streams and riparian areas.

-. Efrdangered Species:

Flora: Plants listed by the Oregon Task Force are known in the west central Cascades and may be in the area.

Wood fern

Bog birch

Cranberry

Reedgrass

Washington lily

Bog orchid

Rue anemone

Matted saxifrage

Pinefoot

- Tall agoseris

Alpine collomia

Crater Lake sardwort
(Thelypteris nevadensis)

(Betula glandulasa)

(Vaccinium oxycoccus var. intermedium)

(Calamagrostis breweri)

(Lilium Washingtoníanum)

(Habenaria orbiculata)

(Isopyrum hallii)

(Saxifraga bronchialis var. vespertina)

(Pityopus californicus)

(Agoseris elata)

(Collomia debilis var. larsenii)

(Arenaria pumicola) 
Fauna:

American peregine falcon (Falco peregrinus anatum)

Arctic peregine falcon (Falco peregrinus tundrius)

THREATENED SPECIES:

Wolverine (Gulo luscus)--one siting from the Mt. Jefferson Wilderness.

Northern Blad eagle (Haliaeetus leucocephalus alascanus)-- no known nesting sites in area.

Northern spotted owl (Strix occidentalis caurina) habitat is old growth Douglas fir forest. 
TRANSPORTATION AND UTILITIES

\section{SITE: MC CREDIE HOT SPRINGS KGRA}

..Utility or Energy Transmission Corridors and Facilities:

None in area.

..Transportation Corridors or Facilities and Right-of-Ways:

Access is via State Highway 58 (Willamette Highway) and National Forest system roads. In addition, there are numerous logging roads in the vicinity.

Southern Pacific Railroad holds 10 special use permits for a railroad and ancillary installations in the area. The railroad lies within a quarter mile of McCredie Hot Springs.

Permit for a rock stockpile site adjacent to Highway 58 Mile Post 47.70 is held by the Oregon Highway Department.

There are no grazing al lotments. 


\section{POPULATION}

SITE: MC CREDIE HOT SPRINGS KGRA

\section{..General Description of Population}

Human occupancy is essentially transitory in nature.

Recreationists, logging industry employees and Forest Service employees are in the area on a non-residency basis.

The nearest population centers are:

Oakridge, a lumber and railroad town, with a population of 4,300 located about $14.5 \mathrm{~km}$ ( $9 \mathrm{mi}$ les) from Mccredie Hot Springs.

Westfir, a lumber mill town located $5 \mathrm{~km}$ ( $3 \mathrm{miles})$ northwest of 0akridge.

..Economics

..Present Land Use:

Recreation and timber production

Timber from the area provides some support for the economy of Oakridge and other upper Willamette Val ley urban areas. Total standing merchantable volume on the 19,603 acres of EIS study area is estimated to be $789,857,000$ board feet.

Douglas fir is the principal timber species, with western hemlock, noble fir. Pacific silver fir, mountain hemlock, western white pine, western redcedar and incense cedar contributing smaller volumes to the total.

\section{Recreation}

Blue Pool Campground is only developed recreation site in the area. Located between Highway 58 and Salt Creek about .5 mile west of McCredie Hot Springs. Facilities include 19 camping units and 5 picinic units with a daily capacity of 140 persons. 
Two additional sites, totalling 16 acres have been identified as being suitable for recreational development. One of these tracts is at McCredie Hot Springs. It includes the site formerly occupied by the McCredie Hot Springs Resort Lodge. Resort use terminated in 1958 when the lodge burned.

Principal recreational activities: fishing, hunting (elk and deer), camping, and hiking.

(3)

\section{Fishing}

Salt Creek and Black Creek are the most frequently fished streams in the area. They support a sport fishery based largely on the Oregon Department of Fish and Wildlife stocking program, al though native fish are also present. (Cutthroat and Rainbow trout) 
Cascade Region References

(1) White, D. E. and Williams, D. L., eds., 1975, Assessment of Geothermal Resources of the United States - 1975: U.S. Geological Survey Circular 726.

(2) U.S. Forest Service, 1977, Final Environmental Statement for the Proposed Interagency Plan, Mt. Hood Planning Unit.

(3) Waring, Gerald, A., 1965, Thermal Springs of the United States and Other Countries of the Wor Id - A Summary: U.S. Geological Survey Professional Paper 492.

(4) U.S. Geological Survey, Conservation Division, 1978, Environmental Analysis Report: Office of the Area Supervisor, EA \#105-8.

(5) Bureau of Land Management, Non-Competitive Geothermal Leasing Serial Register, State Office, Portland, Oregon.

(6) Phillips, K. N., 1935, A Chemical Study of Fumaroles on Mount Hood: Mazama, V. 18.

(7) Williams, F., et. al., 1977, Site-Specific Analys is of Geothermal Development - Data Files of Prospective Sites: The Mitre Corporation, Vol. 111.

(8) U.S. Geological Survey, Geothermal Resources File (Geotherm) Revision 8, Computer Data File.

(9) Wise, William, R., 1968, Geology of Mt. Hood Volcano: Andesite Conference Guidebook, Oregon Department of Geology and Mineral Industries Bullet in 62.

(10) Port land General Electric, 1976, Prospects for Electric Power General from Geothermal Energy: Internal Report to Management.

(11) Wise, Hill1am, R., 1969, Geology and Petrology of the Hit. Hood Area: A Study of High Cascade Volcanism: Geological Survey of America Bulletin, V. 80 .

(12) Peck, P. L., et. al., 1964, Geology of the Central and Northern Parts of the Western Cascade Range in Oregon. U.S. Geological Survey Professional Paper 449.

(13) Newton, V. C., and Hul1, D. A., 1978, Geothermal Energy in 1977: Ore Bin, V. 40, N.1, January 1978.

(14) Hook, J., Personal Communication. 
(15) Riccio, J., Oregon Department of Geology and Minera1 Industries, Personal Communication.

(16) Mount Hood Geothermal Drilling Program Continues: Ore Bin, Vol. 40, N. 10, October 1978.

(17) Mt. Hood National Forest, 1978, Summary of Initial Public Input - Clackamas Planning Unit.

(18) Culver, G., Correspondence, March, 1978.

(19) Mariner, R. H., Rapp, J. B., Willey, L. M. and Presser, T. S., 1974, The Chemical Composition and Estimated Minimum Thermal Reservoir Temperatures of Selected Hot Springs in Oregon: U.S. Geological Survey, Open File Report.

(20) Baldwin, E. M., 1964, Geology of Oregon: University of Oregon, Eugene.

(21) Hammond, Paul E., 1976, Preliminary Report on the Reconnaissance Geology of the Upper Clackamas and North Santiam Rivers Area, Cascade Range, Oregon: Draft Report to Oregon Department of Geology and Mineral Industries.

(22) Geyer, John, Mt. Hood National Forest, Personal Communication, July, 1978.

(23) U.S. Forest Service, 1978, Oregon Supplement to the Draft Environmental Statement: Roadless Area Review and Evaluation II.

(24) Hu11, D. A., B1ackwel1, D. D., Bowen, R. G., Peterson, N. V., and Black, G. L., 1977, Geothermal Gradient Data: Oregon Department of Geology and Mineral Industries, Open File Report 0-77-2.

(25) Hull, D. A., Blackwell, D. D., and Black, G. L., 1978, Geothermal Gradient Data: Oregon Department of Geology and Mineral Industries, Open File Report 0-78-4.

(26) Mt. Hood National Forest, 1978, Attachment to the Oregon State Supplement of the USDA Forest Service Environmental Statement on Roadless Area Review and Evaluation II.

(27). U.S. Geological Survey, Known Geothermal Resource Areas as Classified by the Indicated Area Geologists Western and Central Regions: U.S. Geological Survey, unnumbered paper.

(28) Willamette National Forest, 1978, Final Environmental Statement on Geothermal Development - Breitenbush Area. 
(29) Clayton, C. M., 1976, Geology of the Breitenbush Hot Springs Area, Cascade Range, Oregon: Portland State University Master's Thesis.

(30) Newton, v. C., Personal Communication, March, 1978.

(31) Cone, Joe, "Some Like it Hot", Oregon Magazine, October, 1978.

(32) Willamette National Forest, Working Copy of Belknap-Foley Environmental Impact Statement.

(33) Willamette National Forest, Working Copy of McCredie Geothermal Area Environmental Impact Statement.

(34) Mariner, R. H., Rapp, J. B., Willey, L. M. and Presser, T. S., 1975, The Minor and Trace Elements, Gas, and Isotope Compositions of the Principal Hot Springs of Nevada and Oregon: U.S. Geological Survey, Open File Report. 

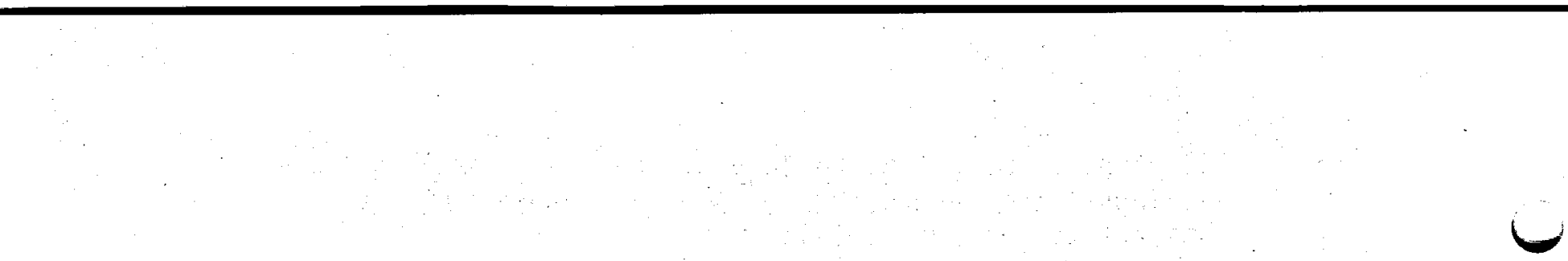

362 


\section{LEGAL AND INSTITUTIONAL FACTORS}

In general, natural resource development is guided by a vast array of federal, state and local government policies. Geothermal energy development is no exception. Policies, procedures and lows related to environmental, regulatory and statutory controls dictate where and how geothermal resource development may occur.

All to frequently this maze of legal and institutional considerations serves as a barrier to geothermal energy development. However, for the most part, state policies in Oregon have served to foster the development of direct use applications in a relatively unhindered fashion.

Foremost was the passage of legislation in 1975 allowing the formation of geothermal heating districts. This legislation, as contained in Oregon Revised Statutes Chapter 523 (1977 Replacement Part) (Appendix D), authorizes the incorporation of communities for the purpose of supplying inhabitants with geothermal heat. It allows heating districts to contract for services, sue and be sued, issue general obligation, revenue or refunding bonds, form cooperative agreements, exercise the power of eminent domain, levy special assessment taxes and ad valorem taxes and provide supplemental energy from sources other than geothermal in times of emergency. In addition, geothermal heating districts may purchase, sell and hold interests in water and real property, and may receive private or federal grants, loans or other funds for carrying out objectives of the district. This model legislation, the first of its kind in the country, has enabled Klamath Falls to initiate the formation of a geothermal heating district.

To encourage homeowners to use geothermal energy for space and hot water heating, the Oregon Legislature enacted Senate Bill 339 during the 1977 session. The measure provides for a tax credit of 25 percent of the cost of an alternate energy device up to $\$ 1,000$. Geo heating and cooling systems which are certified by the Oregon Department of Energy before installation can qualify for this tax credit.

In addition to the tax credit incentive, geothermal space heating for residential and small commercial interests is simplified by the exclusion of shallow (less than 2,000 feet), low termperature (under $250^{\circ} \mathrm{F}$ ) resources from the provisions of the Geothermal Resource Act (ORS Chapter 522) (Appendix E). This means that a typical well for home heating in Klamath Falls can be drilled as a water well under the Department of Water Resources regulations. 
Geothermal wells which are more than 2,000 feet in depth or $250{ }^{\circ} \mathrm{F}$ are regulated by the Oregon Department of Geology and Mineral Industries. Administrative Rules which govern the drilling of such wells are contained in "Rules, Regulations and Laws Relating to Exploration and Development of Geothermal Resources in Oregon" issued in 1977. The rules have recognized the distinction between prospect and production wells and have provided for separate blow-out prevention requirements. The Department has also reached an agreement with the Department of Environmental Quality to incorporate environmental stipulations in well permits which reduces regulatory procedures for the developer.

However, the division of authority between the Department of Geology and Mineral Industries and Department of Water Resources raises some interesting questions concerning ownership and water appropriation. As defined in ORS 522.005(7), "geothermal resources" means the natural heat of the earth, the energy in whatever form, or created by, or which may be extracted from, the natural heat, and all minerals....". Ownership rights as outlined in ORS 522.045 "shall be in the owner of the surface property underlain by the geothermal resources unless such rights have been otherwise reserved or conveyed. However, nothing in this section shall divest the people or the state of any rights, title or interest they may have in geothermal resources." Section 522.025 states that provisions of the chapter do not apply to shallow, low temperature wells but does not say that this identified type of well is not a geothermal resource. The assignment of this type of well to Department of Water Resources jurisdiction seems to imply that shallow, low temperature geothermal resources may be a groundwater resource and thereby in public trust reserved to the state. Since the definition of geothermal resources does not reflect the division outlined for regulatory purposes, the question remains who actually owns and controls the resource.

As well, despite the provision that ownership rights to geothermal resources are given to the owner of the surface estote, any water withdrawn and released from a geothermal well is subject to appropriation under state water law. This raises the question of whether or not the Department of Water Resources has the authority to require water appropriations for all geothermal fluids including those regulated by the Department of Geology.

It is not perceived that these concerns are hindering geothermal development in Oregon, but they should be clarified, nonetheless, before they become problems. One solution would be to provide by statute that geothermal resources of either fluid or vapor type not be restricted by established water rights unless substantial interference can be demonstrated. 
A potential conflict concerns the classification of heat os a beneficial use. To acquire a water appropriation a beneficial use must be demonstrated, and heat extraction is not now considered to meet the advantageous criteria. One can envision a case where a geothermal resource developer plans to use a downhole heat exchanger in a closed system but is unable to obtain a water right. The developer might then decide to use the thermal fluids directly to gain an appropriation which raises questions about disposal, possible corrosion problems and conservation of the resource. Clearly, the extraction of heat from thermal water needs to be added to the list of accepted beneficial uses.

This and other policy concerns may be addressed by the 1979 Oregon Legislature in response to a National Conference of State Legislatures project which was recently begun in the state. The project seeks to identify areas of policy concern, assist in analysis of the issues and stimulate legislative action. Clarification of policy and regulatory issues is an important step at this point to prevent obstacles and potential legal suits for future geothermal development.

In addition there are several other activities taking place in the state which will foster the development of geothermal resources. The Oregon Graduate Center is conducting an environmental overview to identify potential concerns and recommend areas for environmental baseline studies. A task force comprising of representatives of the Departments of Environmental Quality, Energy, Water Resources and Geology and Mineral Industries have been directed to recommend uniform policies regarding geothermal fluid disposal by House Joint Resolution 50. One of the recent encourogements to bringing geothermal resources "on-line" in the near-term was the Economic Development Commission's selection of geothermal energy as a target for industrial development. This should facilitate the location of suitable industries in areas with sufficient resources for meeting process energy requirements. As well, the Department of Geology and Mineral Industries has assumed a willing posture to conduct resource assessment activities. Projects such as the Mt. Hood resource Gssessment will provide a better understanding of the nature of the resource and help to build institutional confidence.

Geothermal leasing on state land is allowed under the provisions of "Geothermal Lease Regulations" in the Division of State Land's Administrative Rules 141-75, 1975. Salient features include: exploration permits, two-tier leasing, 10 year primary lease term, renewal provisions, escalating annual rental, royalties, and environmental impact reports. 
Taking all of these factors into account it appears that the legal and institutional framework for the development of direct use geothermal applications is reasonably straightforward. The question then arises as to why geothermal resources are not being more actively developed. The answer is related to economics and lack of financial incentives which will be discussed in further detail in the overall view of impediments to development.

Utilization of geothermal resources for electric power generation is likely to encounter more stringent institutional controls. However, most of these factors are reasonable safeguards to protect the environment since the impacts of a power plant are more significant than the implications of direct use applications.

There are now no regulations for the siting of a geothermal power plant or pipeline. Although there is not a confirmed resource which would call for an application for a site certificate, a siting application for a geothermal pipeline could be forthcoming within a year or two. The obsence of regulations could delay the siting procedure. Applications must be filed and site certificates granted, if deemed appropriate by the Energy Focility Siting Council for electric power production plants with a minimum generating capacity of $25 \mathrm{MW}$ and for pipelines six inches or greater in diamter and five miles or longer in length It is imperative that regulations governing the siting of such facilities be in place before applications are filed to prevent needless deloys.

A deterrent to the siting of geothermal power plants is the suitability/unsuitability survey which classifies many areas that show potential for development as unsuitable. In the case of geothermal it is suggested that the survey be consulted, but that each application be considered on a site specific basis.

In Oregon approximately 31 million acres or 50 percent of the land is in federal ownership with the U.S. Forest Service and Bureau of Land Management octing as the primary management agencies. The majority of Oregon's identified geothermal resource areas are within this federal land hold. The lack of access to these lands is one of the most significant impediments to geothermal exploration and development in Oregon. Since the regulations cancerning geothermal energy exploration and development as outlined in the Geothermal Steam Act of 1970 and the operating orders of the U.S. Geological Survey, Forest Service and BLM have been adequately. explained in numerous publications, this discussion will focus on specific problems and potential solutions rather than a reiteration of the complex procedural maze. A chart summarizing the leasing process on federal land has been included as Appendix G. 
The primary inhibiting factors are the inability of developers to obtain access to federal land for leasing and the tedious process of acquiring permits to conduct geothermal operations. For the most part, developers will not proceed with an exploration program without leases to protect the company's investment. Leasing of national forest land is particularly constraining because of the length of time required to process applications and the commitment of capital for long periods of time. There are lease applications on national forest land that have been pending since 1974. With this time frame, it is easy to understand why in many cases only large companies can afford to conduct geothermal exploration activities. Even they get frustrated with lengthy procedural delays and may divert funds to other investments. A potential solution is to establish specific time periods for processing of lease applications. If investors have a predictable time for commitment of funds they moy be more likely to undertake geothermal development.

Leasing laws and procedures make it difficult to obtain the leases which are a necessary prerequisite to major exploration. This is particularly true in the case of national forest lands. Environmental evaluations which are both a necessary and desirable procedure consume undue amounts of time. A prime example is a recent Environmental Impact Statement completed for a westem Cascade hot spring area. The document required four years to prepare and publish and then failed to include adjacent lease application areas. A second impact report must be compiled before lease applications in the area can be processed. It would facilitate leasing on federal land to establish priority areas and complete environmental review procedures.

If utilization of geothermal resources is ever to be realized on national forest lands, then the Forest Service must increase its program priority and management commitment to geothermal development. There are signs that this is happening on individual forests in Oregon, but directives from the national and regional offices are needed to provide official policy which lends real support to geothermal exploration and development. The current Roadless Area Review and Evaluation (RARE II) study is a good indication of the Forest Service commitment to geothermal energy. Of the almost 3 million acres under consideration for inclusion into the National Wilderness Perservation system in Oregon, not one acre is classified as having "producing, proven or possible" geothermal resources. This despite the fact that several areas being evaluated have been classified as Known Geothermal Resource Areas by the U.S. Geological Survey. 
Environmental impacts reports are causing further delays in the development of geothermal energy not only by the lengthy process of preparation but by the scope in which impacts are assessed. Since environmental analysis must precede exploration, the nature of the resource is not known. A realistic measure of impacts is virtually impossible. The Forest Service method has been to consider the worse case approach. This has resulted in projections of Geyser-type developments in forested areas where the geothermal resources have been identified as intermediate temperature hydrothermal resources. It is not surprising that environmental groups and the general public raise considerable objections when they review environmental analysis documents which addresses only development of the highest magnitude.

A more reasonable approach, and one which is being considered by the Interagency Geothermal Coordinating Council Streamlining Task Force, would be to provide for leases based upon separate environmental assessment of the exploration and development phases. Environmental analysis for the exploration phase could be based on areawide environmental reports that have been developed during land management planning. This would serve as a review only of the impacts of exploration activities. A comprehensive site specific analysis of development impacts would be made only if a sufficient resource were discovered during exploration. The lessee's rights to develop would be conditional based on the outcome of the comprehensive environmental analysis. Canditional rights would be established through lease stipulations. This method would not anly serve to provide a more realistic assessment of environmental impacts thereby facilitating more sound judgmental decisions regarding possible development, but would be less of a financial and man-power drain on the Forest Service since existing documents could be used in the initial reviews and comprehensive specific analysis would be required only for development. This approach would simplify the procedures for geothermal exploration without sacrificing the importance of environmental impact onalysis.

When preparing environmental reviews of geothermal development both the Forest Service and the BLM should address the severity of geothermal impacts as compared with the impacts of other energy sources. Generally, environmental reviews have not compared the impact of geothermal development to the impacts of other resource development, but rather compared it with the effect of no development. At some point, it will be necessary to balance energy and environmental goals, and if comparisons can be drawn now as environmental analysis are prepared it will provide essential background information for future decisions. 
A major obstacle to geothermal development is lack of knowledge of the nature and extent of geothermal resources in Oregon. It appears that Oregon has the potential to meet a significant portion of its energy demand by utilizing geothermal resources, but until a more aggressive program of resource assessment consisting of geophysical and geochemical studies and test drilling is undertaken, it will remain just that - potential - not power on-line. The immediate focus of federal geothermal programs should be to put the bulk of their available funding into resource assessment and reservoir modeling through the U.S.G.S. and cooperative programs with state geology offices. Once resource assessment has established parameters for geothermal energy utilization, planning and feasibility studies can be carried out in a more realistic manner. As well, resource confirmation will decrease the risks involved in geothermal development which has been a major inhibiting factor in securing financial commitments.

To encourage private exploration on federal land the U.S.G.S. should revise the criteria for designating known geothermal resource areas (KGRA). A review of the leasing status in Oregon reveals that the pace of leasing and exploration in KGRAs lags behind activity on non-competitive lease areas. Provisions ore necessary which will encourage exploration in KGRAs through redefining the KGRA classification procedures and including elements which will motivate exploration and development. Efforts should also be made to reclassify KGRAs ofter they have been offered during two lease sales and received no bids. Several portions of KGRAs including Klamath Falls, Vale, Crump Springs and Burns Butte have been offered as many as three times and no bids have been received.

To bring more power on-line in the near term federal and state programs should focus on providing incentives for direct use applications. The technology is in place and adequate resources have been identified for non-electric uses, but the accomplishment of this development appears to be largely dependent on federal assistance at this time. Targets should be established to work with industries, pnrticularly agribusiness, which are potential users of geothermal resources and municipalities for establishing geothermal heating districts. This should be accomplished through demonstration/pilot projects, federal guaranteed loans, grants, technical assistance and outreach programs. When the feasibility of utilizing geothermal resources has been demonstrated by federally assisted projects, it is assumed that private industry will be stimulated to continue development with private capital. 
District heating systems could be further encouraged if legislation were passed allowing municipalities and others the same provisions that are provided in other mineral acts. Federal land could be set aside for municipalities or other organizations for direct use applications. A possible consideration to stimulate the formation of heating districts, would be to allow municipalities first right of refusal on competitive bid acreage.

Throughout the years the major impediment to geothermal exploration and development has been the lack of financial incentives. But with the passage of the National Energy Act in late 1978, parity with other energy resource exploration was established for geothermal energy. The Act authorizes a full depletion allowance of 22 percent for geothermal wells drilled after December 31, 1977, but declines to 15 percent by 1984 on the same basis as for oil and gas. Intangible drilling costs can also be deducted in the same fashion as oil and gas wells.

The Act also allows a 10 percent investment tax credit, in addition to the normal 10 percent investment tax credit, for businesses installing geothermal equipment. Agricultural uses may also qualify. Homeowners who install a geothermal heating, cooling or hot water system may qualify for the residential energy tax credit. The allowance is 30 percent of the first $\$ 2,000$ spent; and 20 percent of the next $\$ 8,000$ for a total maximum of $\$ 2,200$. Provisions of the Bill expand the authority of the Federal Energy Regulatory Commission to order infercomection and wheeling for utilities or co-generators installing geothermal plants, and exempts small geothermal facilities of less than $30 \mathrm{MW}$ capacity from federal public utility regulation.

The enactment of the Bill has resolved a major barrier that has hampered geothermal resource exploration and development for many years. Drilling for geothermal resources is now afforded the same tax advantoges that the oil and gas industry has enjoyed for years. Now, if leasing procedures can be streamlined and a direct use market can be developed, geothermal energy resource exploration and development in Oregon will be greatly stimulated resulting in a significant contr ibution to the state's energy supply. 


\section{SUMMARY}

This report has attempted to compile an inventory of ovailable data pertaining to Oregon's geothermal resources and make reasonable estimates of the potential for geothermal resource development. Preliminary development profiles have been constructed to provide a context for future detailed planning and to identify the near-term actions which are necessary to successful development. An additional objective was to provide an overview of the legal and institutional considerations which will influence development and commercialization of the resource.

Analysis of data collected during the course of this project indicates that there is considerable undeveloped geothermal energy potential in Oregon for both direct use applications and electrical generation. Non-electrical uses offer the greatest immediate potential. Applications most likely to be developed in Oregon are agricultural processing and district heating systems. Agricultural activities that could be supplied with geothermal process and space heat include: greenhouses; potato, sugar beet and onion processing; alfalfa, grain, vegetable and fruit dehydration; barley malting, livestock operations, cold storage facilities, hog pen warming, pasteurization, and mushroom growing. District heating systems appear feasible in the communities of Klamath Falls, Lakeview, LaGrande, Oakridge, Burns and the Vale-Ontario area.

Estimating the potential for electrical power generation from Oregon's geothermal resources is basically conjecture now because no reservoirs of sufficient temperature have been discovered. The Alvord Valley in the southeastern portion of the state offers some of the most favorable indications and deserves further exploration. Other areas which have high temperature potential are Vale, Lakeview, Crump Springs, Newberry Crafer, and Glass Buttes. These sites may prove adequate for high temperature process uses if not restricted by distance from population centers. They may also have some chance of meeting the requirements for electrical generation.

Development potential in the Cascade Mountains is difficult to assess. Indicated temperatures in the moderate range are suitable for direct use applications, but the lack of human occupation in the area is a barrier to possible utilization. Oregon's major population centers in the Willamette Valky are located in a $60-160 \mathrm{~km}$ range from the resource areas, but economic and thermodynamic factors may preclude transporting thermal fluids the necessary distance. As results of the Mt. Hood assessment and Northwest Natural Gas exploration program become available, a clearer picture of the Cascades potential should come into focus. 
Environmental concerns are of vital importance in resource areas such as the Cascades. This lush region is highly valued for watershed, timber production and recreational use by the Willamette Valley population. Without a doubt, geothermal exploration and development will be watched by a keen public eye. State and federal laws exist to regulate exploration and drilling activities and to maintain acceptable air, water and noise quality levels. Nevertheless, a full Environmental Impact Statement will likely be necessary at both the pre-lease and pre-development stages for Cascade resources.

In addition to environmental concerns, policies and actions of public and other institutions will profoundly influence development of geothermal resources. The existing laws and regulations in Oregon seem fairly reasonable, but the state has yet to assume a strong posture in support of geothermal development. Actions similar to the California administration's statement encouraging geothermal development would provide a measure of the state's official position and enhance the opportunity for development.

On the other hand, laws and leasing regulations for federal land are hindering utilization of this in-state resource. Leasing procedures need to be streamlined, and the environmental analysis procedures should be revised to better coordinate the reviews leading to more realistic and less time consuming documents. The Forest Service in particular needs to redefine its priorities to place more emphasis on geothermal resources. The U.S. Geological Survey desperately needs to increase resource assessment activities on federal land and should revise the classification of KGRAs.

A further hindrance is that geothermal development by. its own nature is a capital intensive and somewhat risky financial venture. Resource confirmation resulting from assessment activities will help build institutional confidence, and by lessening the risk factor will make lending institutions more willing to support development projects. Federal assistance is essential in these early stages of geothermal development in Oregon to initiate pilot demonstrations of the feasibility of utilizing the earth's natural heat. This assistance will be needed for technical expertise and financial support. Once the pilot projects are established private industry should be sufficiently stimulated to carry the lead in geothermal resource development.

If these institutional factors can be reconciled and the resources are proven, geothermal energy holds great promise for Oregon. Development of this indigenous resource in an acceptable manner will improve environmental quality by lessening dependence on fossil fuels and will give industries which can utilize the resource a cost-competitive advantage, thereby enhancing the state's economy. Extremely conservative development scenarios illustrate the potential for first stage use of $180 \mathrm{MWt}$ by 1990 for direct use applications and $50 \mathrm{MWe}$ by 1993 for electrical generation. Granted, geothermal resources will never meet all of Oregon's energy requirements, but the potential contribution is significant and may make the deciding difference in assessing the need for future construction of thermal facilities to meet energy supply and demand. 


\section{SELECTED REFERENCES}

Armstead, C. H., ed., 1973, Geothermal Energy, Review of Research and Development: United Nations Educational, Scientific and Cultural Organization.

Baldwin, E. M., 1964, Geology of Oregon: University of Oregon, Eugene.

Berg, J. W., Jr., and Thiruvathukal, J. W., 1967, Complete Bouger Gravity Anomaly Map of Oregon: Oregon Department of Geology and Mineral Industries Map GMS 4-b.

Bonneville Power Administration, 1971, Pocific Northwest Transmission System Map.

Bowen, R. G. and Blackwell, D. D., 1975, The Cow Hollow Geothermal Anomaly, Malheur County, Oregon: Ore Bin, V. 37, N. 7.

Bowen, R. G., Blackwell, D. D., 1975, Geothermal Studies and Exploration in Oregon: Oregon Department of Geology and Mineral Industries Open File Report.

Bowen, R. G., Blackwell, D. D., and Hull, D. A., 1977, Geothermal Exploration Studies in Oregon: Oregon Department of Geology and Mineral Industries Miscellaneous Paper 19.

Bowen, R. G., Blackwell, D. D. and Hull, D., 1975, Geothermal Studies and Exploration in Oregon: Oregon Department of Geology and Mineral Industries Open File Report 0-75-7.

Bowen, R. G., and Peterson, N. V., 1970, Thermal Springs and Wells in Oregon: Oregon Department of Geology and Mineral Industries Miscellaneous Paper 14.

Bureav of Land Manogement, Geothermal Leasing Serial Register, State Office, Portland, Oregon.

Bureau of Land Management, 1974, Vale Environmental Analysis Report Geothermal Leasing: Vale District.

Bureau of Land Management, 1975, Crump Geyser Environmental Analysis Report for Proposed Geothermal Leasing: Susanville, California and Lakeview, Oregon Districts.

Bureau of Land Management, 1975, Environmental Analysis Record for Proposed Geothermal Leasing - Klamath Basin, Lakeview and Medford Districts. 
Bureau of Land Management, 1975, Environmental Analysis Report - Alvord Desert Geothermal Leasing Program: Burns District.

Bureau of Land Management, 1977, Environmental Analysis Report for Proposed Geothermal Leasing for Burns District Non-competitive Geothermal Applications and Burns Butte KGRA: Burns District.

Bureau of Land Management, 1975, Proposed Geothermal Leasing - Vale Addition Environmental Analysis Record: Vale District.

Bureau of Land Management, 1976, Summer Lake Environmental Analysis Report for Proposed Geothermal Leasing: Lakeview District.

Clayton, C. M., 1976, Geology of the Breitenbush Hot Springs Area, Cascade Range, Oregon: Portland State University Master's Thesis.

Cone, Joe. "Some Like it Hot", Oregon Magazine, Ocotober, 1978.

Corcoran, R. E., Doak, R. A., Porter, P. W., Pritchett, F. I. and Privrasky, N. C., 1962, Geology of the Mitchell Butte Quadrangle, Oregon: Oregon Department of Geology and Mineral Industries GMS-2.

Couch, R., French, W., Gemperle, M. and. Johnson, A., 1975, Geophysical Measurements in the Vale, Oregon Geothermal Resource Area: Ore Bin V. 37, N.8.

Couch, R. W., 1977, Analysis of Geophysical Data Pertaining to the Vale KGRA, Final Report to the Geothermal Research Program: U.S. Geological Survey Grant 14-08-001 =6-222.

Crocker, Marvin, Personal Communication, Fremont National Forest, 6/19/78.

Culver, G. Correspondence, March, 1978.

Culver, G. G., Lund, J. W. and Svanevik, L. S., 1974, Klamath Falls Hot Water Well Study: Lawrence Livermore Laboratory, University of California, UCRL-13614.

Culver, G. Gene, and Reistad, Gordon, M., 1978, Testing and Modeling of Downhole Heat Exchangers in Shallow Geothermal Systems: Transactions, Geothermal Resources Council Annual Meeting:

Dellechaie, F., 1978, A Geological and Hydro-Geochemical Study of the LaGrande Area, Union County, Oregon: Transactions, Geothermal Resources Council, V. 2.

Deschutes National Forest, 1975, Environmental Analysis Report for Geothermal Leasing in the Ft. Rock Ranger District. 
Donath, F. A., 1962, Analysis of Basin-Range Structure, South-Central Oregon: Geologic Society of America Bulletin, V. 73, N.I.

Drysdale, F. R. and Calef, C. E., 1976, The Energetics of the United States of America: An Atlas : Brookhoven National Laboratory, Upton, New York.

Geyer, John., Mt. Hood National Forest. Personal Communication, July, 1978.

Griscom, A. and Conrad, A., 1975, Principal Facts and Preliminary Interpretation for Gravity Profiles and Magnetometer Profiles in the Alvord Valley, Oregon: U.S. Geological Survey Open File Report 75-293.

Groh, E. A., 1966, Geothermal Energy Potential in Oregon: Ore Bin, V. 28, N.7.

Gulf Oil Company, Favell-Utley Well No. I-ST: Oregon Department of Geology and Mineral Industries Drilling Records.

Hammond, Paul E., 1976, Preliminary Report on the Reconnaissance Geology of the Upper Clackamas and North Santiam Rivers Area, Coscade Range, Oregon: Draft Report to Oregon Department of Geology and Mineral Industries.

Hampton, E. R. and Brown, S. G., 1964, Geology and Groundwater Resources of the Upper Grande Ronde River Basin, Union County, Oregon: U.S. Geological Survey Water Supply Paper 1497.

Hampton, E. R. and Brown, S. G., 1964, Geology and Groundwater Resources of the Upper Grande Ronde River Basin, Union County, Oregon: U.S. Geological Survey Water Supply Paper 1597.

Higgins, Michael W,, and Waters, Aaron, C., 1967, Newberry Caldera, Oregon: A Preliminary Report: Ore Bin, V. 29, N.3.

Hook, J., Personal Communication.

Huggins, Rich, editor, 1978, Northeast Oregon Geothermal Potential: Eastern Oregon Community Development Council, LaGrande, Oregon.

Hull, D. A, 1976, Electrical Resistivity Survey and Evaluation of the Glass Buttes Geothermal Anomaly: Oregon Department of Geology and Mineral Industries Open File Report 0-76-11.

Hull, D. A., Bowen, R. G., Blackwell, D. D., Peterson, N. V., 1975, Geothermal Gradient Data Brothers Fault Zone, Oregon: Oregon Department of Geology and Mineral Industries Open File Report 0-76-2. 
Hull, D. A., Blackwell, D. D., Bowen, R. G. and Peterson, N. V.; 1977, Heat Flow Study of the Brothers Fault Zone, Oregon: Oregon Department of Geology and Mineral Industries Open File Report 0-77-3.

Hull, D. A., Blackwell, D. D., Bowen, R. G., Peterson, N. V., and Black, G. L., 1977, Geothermal Gradient Data: Oregon Department of Geology and Mineral Industries, Open File Report 0-77-2.

Hull, D. A., Blackwell, D. D., and Black, G. L., 1978, Geothermal Gradient Data: Oregon Department of Geology and Mineral Industries, Open File Report 0-78-4.

Kruger, Poul and Otte Carel, 1973, Geothermal Energy-Resources, Production, Stimulation: Stanford University Press, Stanford, CA:

Larson, K. and Couch, R., 1975, Preliminary Gravity Maps of the Vale Area, Malheur County, Oregon: Ore Bin, V. 37, N.8.

Lawrence, R. D., 1976, Strike-Slip Faulting Terminates the Basin and Range Province in Oregon: Geological Society of America Bulletin, V. 87.

Leonard, A. R. and Harris, A. B., 1974, Ground Water in Selected Areas in the Klamath Basin, Oregon: Oregon State Engineer Ground Water Report 21.

Libbey, F. W. 1960, Boron in Alvord Valley, Harney County, Oregon: Ore Bin, V. 22, N. io.

Lienau, P. J., et. al., 1976, Klamath Falls Geothermal Mini-Heating District Feasibility Study: ERDA and Idaho National Engineering Laboratory, Contract No. E (10-1)-1548.

Lienau, Paul, Principal Investigator, 1978, Geothermal Energy for Agri-Business for Klamath and Western Snake River Basirs, Oregon: Geo-Heat Utilization Center, Oregon Institute of Technology.

Lienau, Paul J., Lund, John W., Utilization and Economics of Geothermal Space-heating in Klamath Falls, Oregon: Geo-Heat Utilization Center, Oregon Institute of Technology.

Long, C. L. and Gregory, D. I., 1975, Audio-magnetotelluric Apparent Resistivity Maps for Parts of Harney County, Oregon: U.S. Geological Survey Open File Report 75-297.

Long, C. L., Hoover, D. G. and Bramsoe, E., 1976, Audio-Magnetotelluric Apparent Resistivity Maps, Weiser, Idaho - Vale, Oregon: U.S. Geological Survey Open File Report 75-103. 
Lund, John, W., 1978, Geothermal Hydrology and Geochemistry of Klamath Falls, Oregon Urban Area: U.S. Geological Survey Grant No. |4-08-000|-G-29|.

Lund, John W., Geo-Heat Utilization Center, Personal Cummunication, $11 / 16 / 78$.

MacLeod, N. S., Walker, G. W. and McKee, E. H., 1975, Geothermal Significance of Eastward Increase in Age of Upper Cenozoic Rhyolitic Domes in Southeast Oregon: U.S. Geological Survey, Open File Report.

MacLeod, N. S., Walker, G. W., and Mckee, E. H., 1975, Geothermal Significance of Eastward Increase in Age of Upper Cenozoic Rhyolitic Domes in Southeastern Oregon: U.S. Geological Survey Open File Report 75-348.

Mariner, R. H., Rapp, J. B., Willey, L. M., and Presser, T. S., 1974, The Chemical Composition and Estimated Minimum Thermal Reservoir Temperatures of Selected Hot Springs in Oregon: U.S. Geological Survey Open File Report.

Mariner, R. H., Rapp, J. B., Willey, L. M. and Presser, T. S., 1974, The Chemical Composition and Estimated Minimum Thermal Reservoir Temperatures of Selected Hot Springs in Oregon: U.S. Geological Survey, Open File Report.

Mariner, R. H., Rapp, J. B., Willey, L. M. and Presser, T. S., 1975, The Minor and Trace Elements Gos, and Isotope Compositions of the Principal Hot Springs of Nevada and Oregon: U.S. Geological Survey, Open File Report.

Meyer, Jack, and Hook, John, 1978, Geothermal Study of the Lakeview, Lake County, Oregon: Unpublished Report.

Milora, S. L. and Tester, J. W., 1976, Gecthermal Energy as a Source of Electric Power: The Massachusetts Institute of Technology.

Mount Hood Geothermal Drilling Program Continues: Ore Bin, Vol. 40, N. 10, October 1978.

Mt. Hood National Forest, 1978, Attachment to the Oregon State Supplement of the USDA Forest Service Environmental Statement on Roadless Area Review and Evaluation II.

Mt. Hood National Forest, 1978, Summary of Initial Public Input - Clackamas Planning Unit.

Newcomb, R. C. and Hart, D. $H_{\text {., }}$ 1958, Preliminary Report on the Groundwater Resource of the Klamath River Basin, Oregon: U.S. Geological Survey, Open File Report. 
Newton, V. C., Personal Communication, March, 1978.

Newton, V. C., Jr., and Corcoran, R. E., 1963, Petroleum Geology of the Western Snake River Plain Basin: Oregon Department of Geology and Mineral Industries Oil and Gas Investigation I.

Newton, V. C., and Hull, D. A., 1978, Geothermal Energy in 1977: Ore Bin, V. 40, N.I, January, 1978.

Northwest Energy Policy Project, 1978, Energy Futures Northwest: Sponsored by: Pacific Northwest Regional Commission.

O'Connell, M. F. and Kaufmann, R. F., 1976, Radioactivity Associated with Geothermal Waters in the Western U.S. - Basic Data: U.S. Environmental Protection Agency, Office of Radiation Programs, Las Vegas, Nevada.

Oregon Department of Energy, 1978, Oregon's Energy Future, Second Annual Report: Oregon Department of Energy.

Oregon Department of Geology and Mineral Industries, Well Drilling Log.

Oregon Nuclear and Thermal Energy Council, 1974, State-wide Siting Task Force Report: Oregon Deportment of Energy.

Peck, P. L., et. al., 1964, Geology of the Central and Northern Parts of the Western Cascade Range in Oregon: U.S. Geological Survey Professional Paper 449.

Peterson, N. V., and Groh, E. A., 1965, Newberry Volcano Area Field Trip, Lunar Geological Field Conference Guidebook: Oregon Department of Geology and Mineral Industries Bullet in 57.

Peterson, N. V., and Groh, E. A., 1967, Geothermal Potential of the Klamath Falls Area, Oregon, A Preliminary Study: Ore Bin, V. 29, N.II.

Peterson, N. V., and Groh, E. A., 1969, The Ages of Some Holocene Volcanic Eruptions in the Newberry Volcano Area, Oregon: Ore-Bin, V. 31, N.4.

Peterson, N. V., Groh, E. A., Taylor, E. M., Stensland, E. E., 1976, Geology and Mineral Resources of Deschutes County, Oregon: Oregon Department of Geology and Mineral Industries Bulletin 89.

Peterson, N. V. and McIntyre, J. B., 1970, The Reconnaissance Geology and Mineral Resources of Eastern Klamath County and Western Lake County, Oregon: Oregon Department of Geology, and Mineral Industries Bulletin 66. 
Phillips, K. N., 1935, A Chemical Study of Fumaroles on Mount Hood: Mazama, V. 18.

Phillips, K. N. and VanDenburgh, A. S., 1971, Hydrology and Geochemistry of Abert, Summer and Goose Lakes and other Closed Basin Lakes in South-central Oregon: U.S. Geological Survey Professional Paper 502-B.

Piper, A. M., Robinson, T. W., and Park, C. F., Jr., 1939, Geology and Groundwater Resources of the Harney Basin, Oregon: U.S. Geological Survey Water Supply Paper 841.

Plouff, D. and Conradi, A., Jr., 1975, Gravity and Magnetic Profiles and Maps, Crump Geyser Area, Oregon: U.S. Geological Survey Open File Report 75-346.

Portland General Electric, 1976, Prospects for Electric Power Generation from Geothermal Energy: Internal Report to Management.

Portland General Electric, 1976, Prospects for Electric Power from Geothermal Energy: Internal Report to Management.

Prostka, H. J., 1962, Geology of the Sparta Quadrangle, Oregon: Oregon Department of Geology and Mineral Industries Map.

Purvine, W. D., 1974, Utilization of Thermal Energy at Oregon Institute of Technology, Klamath Falls, Oregon, Multi-purpose Use of Geothermal Energy: Oregon Institute of Technology.

Reistad, G. M., Schmisseur, W. E., Shay, R. J., and Fitch, J. B., 1978, An Evaluation of Uses for Low to Intermediate Temperature Geothermal Fluids in the Klamath Basin, Oregon: Oregon State University Engineering Experiment Station, Bulletin No. 55.

Riccio, J., Oregon Department of Geology and Mineral Industries. Personal Communication.

Sacarto, Douglas, M., 1975, State Policies for Geothermal Development: Uncovering a Major Resource: National Conference of State Legislatures.

Sammel, E. A., 1976, Hydrologic Reconnaissance of the Geothermal Area near Klamath Falls, Oregon: U.S. Geological Survey Water Resources Investigation Open File Report WRI 76-127.

Sammel, E. A., 1976, Hydrologic Reconnaissance of the Geothermal Area near Klamath Falls, Oregon: U.S. Geological Survey Open File Report WRI 76-167. 
Sass, J. H., Galanis, S. P., Munroe, R. J. and Urban, T. C., 1976, Heat Flow Data from Southeastern Oregon: U.S. Geological Survey Open File Report 76-217.

Sass, J. H. and Sammel, E. A., 1976, Heat Flow Data and Their Relation to Observed Geothermal Phenomena near Klamath Falls, Oregon: Journal of Geophysical Research, V. 81, N.26.

Stewart, J. H., Walker, George W., and Kleinhampl, F. J., 1975, Oregon-Nevada Lineament: Geology, V. 3, N.5.

Storey, David M., 1974, Geothermal Drilling in Klamath Falls, Oregon, Multi-purpose Use of Geothermal Energy: Oregon Institute of Technology.

Union County Overall Economic Development Program Committee, 1977, Union County-Overall Economic Development Program: Union County, La Grande, Oregon.

University of Wyoming, 1977, Land and Water Law Review: Univerșity of Wyoming, Volume XIII, No. I.

U.S. Forest Service, 1977, Final Environmental Statement for the Proposed Interagency Plan, Mt, Hood Planning Unit.

U.S. Forest SErvice, 1978, Draft Environmental Statement Timber Management Plan, Fremont National Forest.

U.S. Forest Service, 1978, Oregon Supplement to the Draft Environmental Statement: Roadless Area Review and Evaluation II.

U.S. Forest Service, 1978, Oregon State Supplement to the Draft Environmental Impact Statement Roadless Area Review and Evaluation II.

U.S. Geological Survey, Conservation Division, 1978, Environmental Analysis Report: Office of the Area Supervisor, EA \#| 105-8.

U.S. Geological Survey, Geothermal Resources File (Geotherm) Revision 8, Computer Data Fille.

U.S. Geological Survey, Known Geothermal Resource Areas as classified by the Indicated Area Geologists Western and Central Regions: U.S. Geological Survey, unnumbered paper.

U.S. Geological Survey, Water Supply, 1976, Water Resource Data for Oregon - Water Year 1975: U.S. Geological Survey Water Data Report OR-75-1. 
Van Ornum, J., et. al., 1977, Industrial Waste Heat for Adjacent Communities and Industrial Applications, TASK I: Rocket Research Company, Redmond, Washington.

Vaughan, E., Deschutes National Forest. Personal Communication, October, 1978.

Waggoner, Marjorie, Personal Communication, Bureau of Land Management, $3 / 10 / 78$.

Wahl, Edward F., 1977, Geothermal Energy Utilization: John Wiley \& Sons, Inc., New York.

Walker, G. W., 1963, Reconnaissance Geological Map of the Eastern Half of the Klamath Falls (AMS) Quadrangle, Lane and Klamath Counties, Oregon: U.S. Geological Survey Mineral Investigations Field Studies Map MF-260.

Walker, G. W., 1973, Reconnaissance Geologic Map of the Pendleton Quadrangle, Oregon and Washington: U.S. Geological Survey Miscellaneous Geologic Investigation Map I-727.

Walker, G. W., and Repenning, C. A., 1965, Reconnaissance Geologic Map of the Adel Quadrangle, Lake, Harney, and Malheur Counties, Oregon: U.S. Geological Survey Miscellaneous Geologic Investigation Map 1-446.

Walker, George W., 1969, Geology of the High Lava Plains Province, Mineral and Water Resources of Oregon: Oregon Department of Geology and Mineral Industries Bulletin 64.

Walker, George W., 1974, Some Implications of Late Cenozoic Volcanism to Geothermal Potential in the High Lava Plains of South-Central Oregon: Ore Bin, V. 36, N.7.

Waring, Gerald A., 1965, Thermal Springs of the United States and Other Countries of the World - A Summary: U.S. Geological Survey Professional Paper 492.

White, D. E. and Williams, D. L., eds., 1975, Assessment of Geothermal Resources of the United States - 1975: U.S. Geological Survey Circular 726.

Willamette National Forest, 1978, Final Environmental Statement on Geothermal Development - Breitenbush Area.

Willamette National Forest, Working Copy of Belknap-Foley Environmental Impact Statement. 
Willamette National Forest, Working Copy of McCredie Geothermal Area Environmental Impact Statement.

Williams, F., et. al., 1977, Site-Specific Analysis of Geothermal Development - Data Files of Prospective Sites: The Mitre Corporation, Vol. III.

Wise, William, R., 1968, Geology of Mt. Hood Volcano: Andesite Conference Guidebook, Oregon Department of Geology and Mineral Industries Bulletin 62.

Wise, William R., 1969, Geology and Petrology of the Mt. Hood Area: A Study of High Cascade Volcanism: Geological Survey of America Bulletin, V. 80. 


\section{APPENDIX A}

\section{EXISTING USES OF GEOTHERMAL ENERGY IN OREGON}

\section{Space Heating}

Klamath Falls, Lakeview, Vale, Hot Lake, Haines, Breitenbush Hot Springs, Summer Lake, Ontario.

\section{Aquaculture}

Klamath Falls

\section{Greenhouses}

$$
\text { Lakeview, Klamath Falls, Cove, Vale }
$$

Numerous geothermally heated spas and pools around the state.

\section{Projects Under Construction}

Food processing industry - Ontario

District heating system - Klamath Falls

Mushroom growing facility - Vale 


\section{APPENDIX B}

SELECTED INDUSTRIAL ENERGY CONSUMPTION DATA

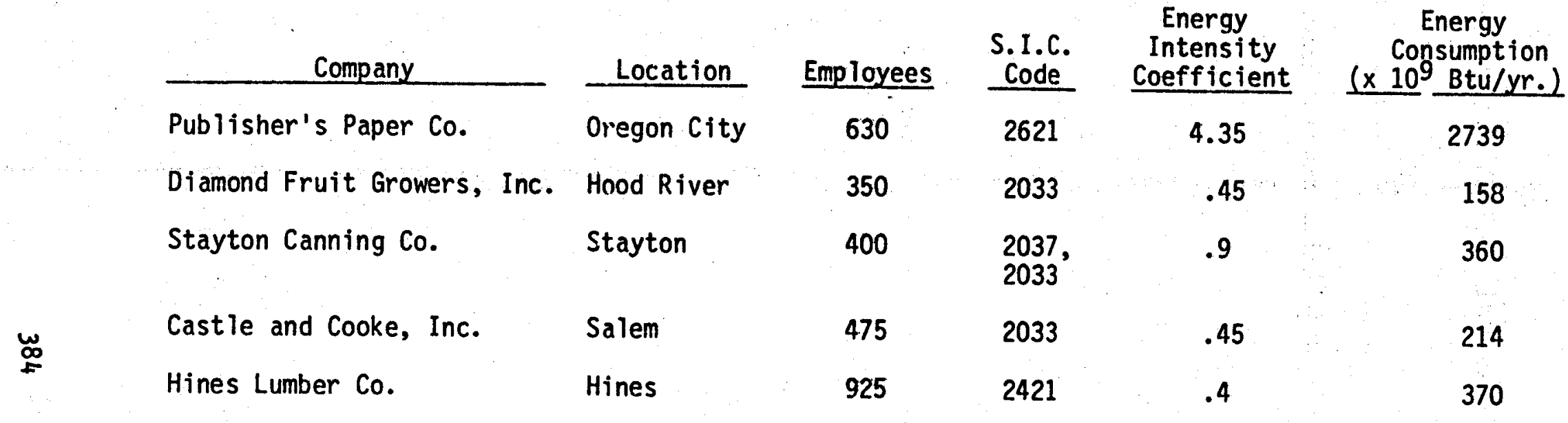

Source: Industrial Waste Heat for Adjacent Communities and Industrial Applications, Rocket Research Corp., 1977. 
OREGON GEOTHERMAL LEASING ACTIVITY

\author{
Non-Competitive Leasing Activity - Federal Land \\ Applications filed \\ 1142 \\ Applications withdrawn or rejected \\ 538 \\ Leases in effect \\ 120 \\ Leases relinquished \\ 20 \\ Pending applications \\ 115 (BLM) \\ 349 (Forest Service)
}

Non-Competitive Leases in Effect:

BLM (99)

135,852 acres

Forest Service (21) 37,892 acres

173,744 total acres under lease

Competitive Leasing Activity - Federal Land

Competitive leases in effect

BLM (27)

60,685 acres

Forest Service (4) $\quad 5,818$ acres

66,503 total acres under lease 
Known Geothermal Resource Areas*

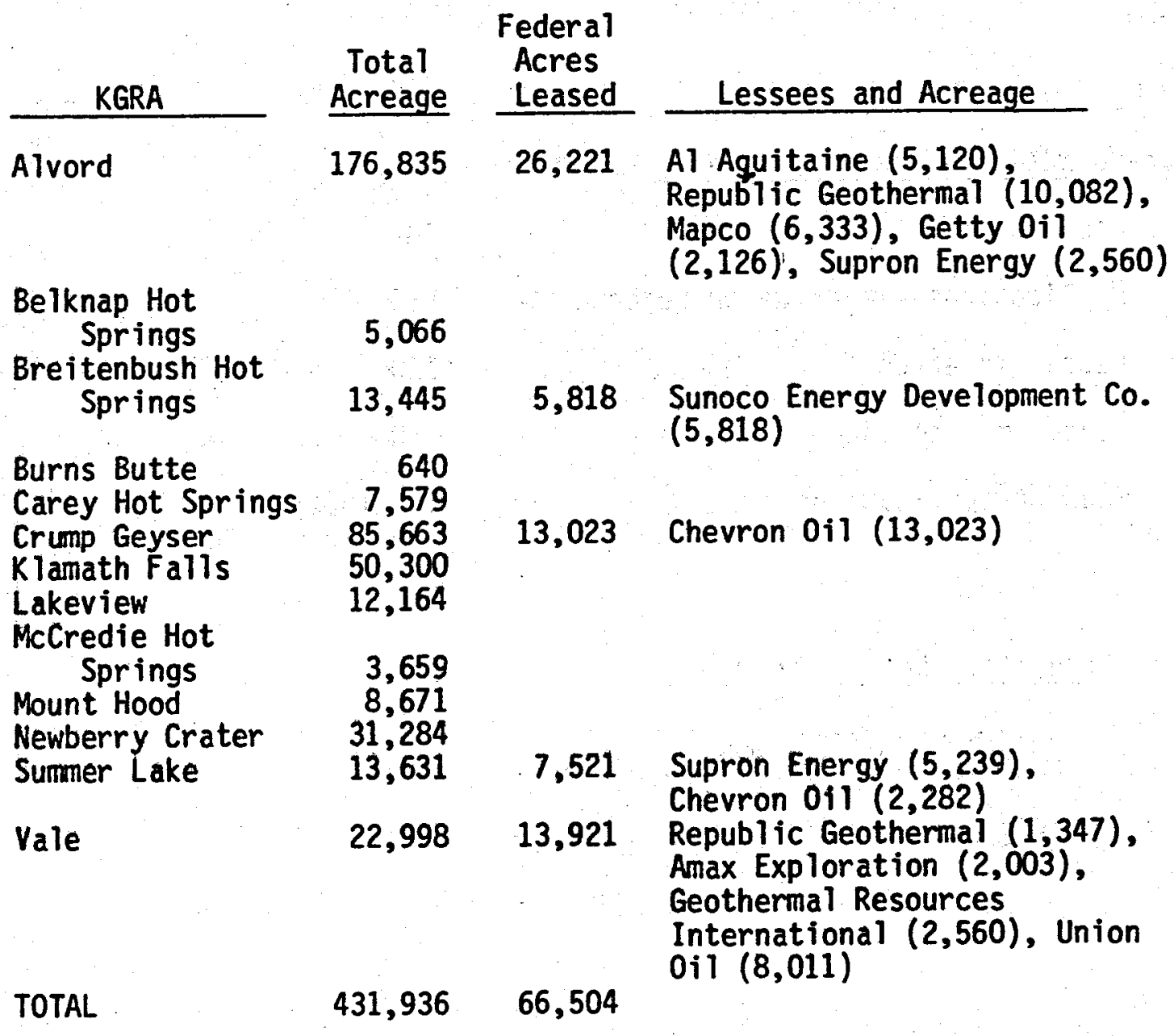

*As classified by the U.S. Geological Survey 
Leasing Activity - State Land

\begin{tabular}{|c|c|c|}
\hline Area & $\begin{array}{l}\text { State } \\
\text { Acres } \\
\text { Leased }\end{array}$ & Les gees and Acreage \\
\hline Alvord & 2,800 & $\begin{array}{l}\text { Max Millis }(1,280) \text {, } \\
\text { Intercont inental Energy }(640) \text {, } \\
\text { Thermogenics }(880)\end{array}$ \\
\hline $\begin{array}{l}\text { Wamer Valley (Crump) } \\
\text { Glass Buttes } \\
\text { Bully Creek (Vale) } \\
\text { Summer Lake } \\
\text { TOTAL }\end{array}$ & $\begin{array}{r}1,280 \\
3,200 \\
640 \quad A \\
374 \\
8,294 \text { Acres }\end{array}$ & $\begin{array}{l}\text { Intercontinental Energy }(1,280) \\
\text { Phil1 ips }(3,200) \\
\text { Amax }(640) \\
\text { Aminoil }(374) \\
\text { S }\end{array}$ \\
\hline
\end{tabular}

Leasing Surmary

Non-Competitive Leases

Competitive Leases

State Leases

TOTAL

173,744 acres

66,504 acres

8,294 acres

248.542 acres 


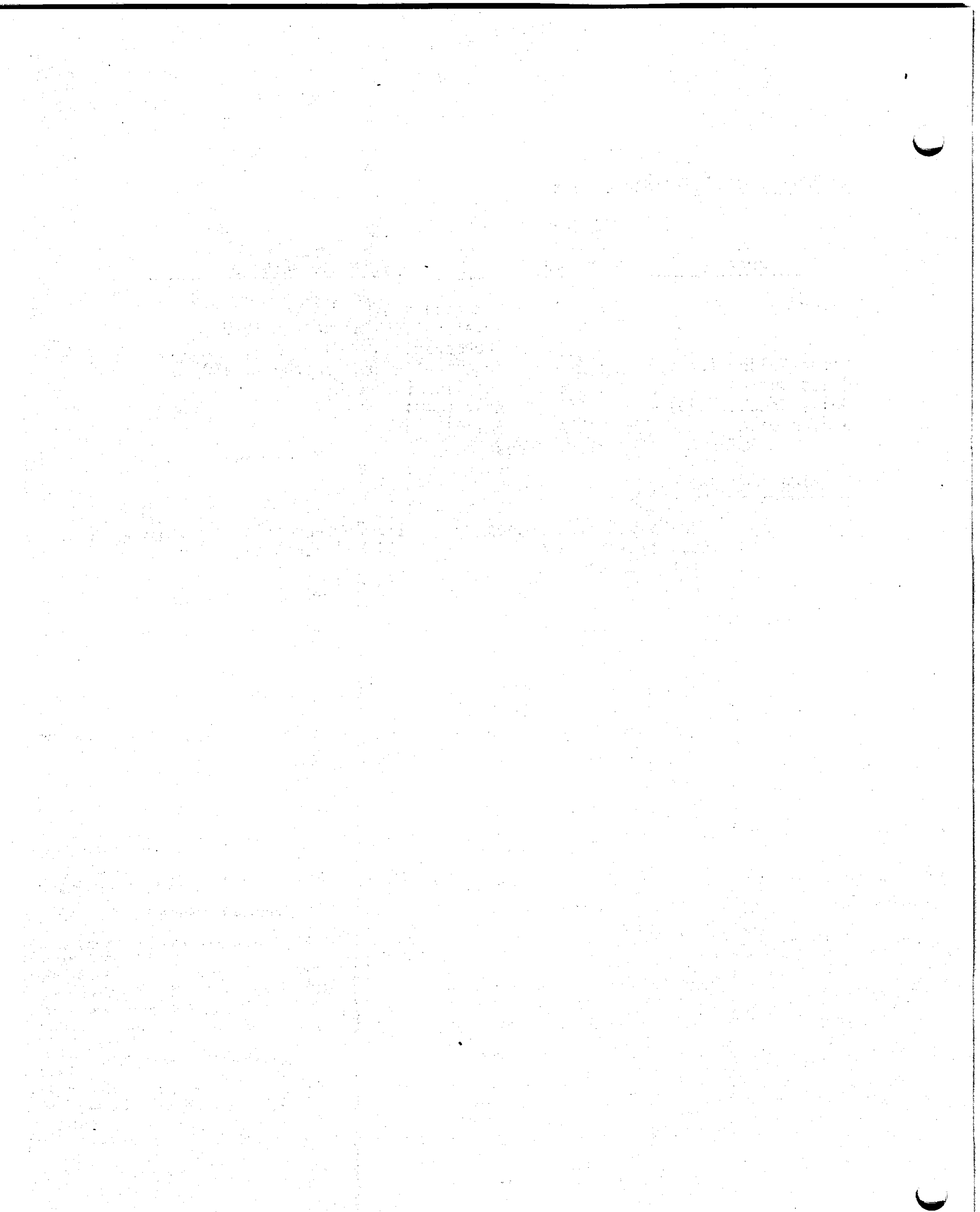




\title{
Chapter 523
}

\author{
1977 REPLACEMENT PART
}

\section{Geothermal Heating Districts}

523010

B23015

503020

623050

69300

$\cos 000$

$\cos 000$

523070

ors.110

$\cos 100$

623.180

023.140

523.160

623.160

$\cdot$

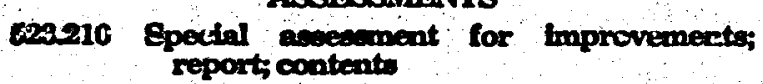

623920 Action on epocial assecument report by boend

co3rso Approval of epecial ascoscinent report Dotice of improvement; contents

623240 Means of construction toprovement

623250

629200

623270

623280

523200

623510

523520

Definitions

Definitions for ORS 153.020

\section{CREATION AND ROWHRS}

Incarpartion of geothermal heating districte; dispoeal of explus excluaton from district

Powers of diftetcti emerivency power, applying for financing piftes and pront sipht to obtaln goothermal beat from other eources

Cooperative andecuntente boods

Authoxity to perform drainage work

\section{OPERATION}

Rulation on une of geothermal beat eifect of fallure to comply

Deposte for une of bent

The increase procedum beating charre

Refund $\alpha$ beating wervice extendion costs by owner of adjacent property

Order to carry out or abandon improve ment after public bearing ascescoment ondinance

Method of assesament

Appeal of assediment

Notice of aseceament to property owners; publication; comtents

Entry of amount of assessment; lien; priority; foreclosure

Errors in assescument

Deficit assessment; hearing; objections; notices
623.950 Excess ascesenent; credit; rebate

c2ss40 Abandonment of improvement; cancellation of biens; refunds

603550

623560

628570

624880

Reatriction on rendering

ascessment Invalid; correction by board

Reascesoment

Application of certain providons of ORS chapters 223 and 287 to assessments

Foreclosure of assesament lien

\section{TAXTNG POWER}

623.410

Ad valonem taration; epecial tax; colleo tion; enforcement

623.420 Dispoal of tares levied by invalid district

\section{BONDS}

602400

Ceneral obligation bonds; limit; lesuance; mnturity; Interest; election; pledge of revenue

623470 Revenue boads terms; lesuance

623480

623.400

Refunding boinds

Advertising and wale of boods

\section{DIsSOLUTMON}

603610

Assumption of debts and obligations of district upon diseolution

\section{ADMIINISTRATION}

529610

5028020

623630

623.640

523.650

623660

523.670

523680

623.680

523.700

523.710

Board; election; power; term; organization Blection

Meetings; officers; quorum employes; employe benefits

Special election

Initiative and referendium

District funds; deposit; records

Agreements between district and annexed city

mployes retirement yrotem; establish. ment; contents

Payments to retirement plan fund

Employe contributions to retirement plan

Limit on eligible individuals in retirement plan 


\section{CROSS REFERENCES}

\section{CROSS REFERENCES}

Air and water pollution control permit for geothermal well drilling and operation, 468.350

623.480

623.460

Information on bond issues to Municipal Debt Advisory

Cormmission, 287.040, 287.042

Advance refunding bonds, state regulation, 288.609 to 288.695

523620

Regular biennial elections required, 259.235 


\section{DEFINITIONS}

623.010 Definitions. As used in this chapter unless the context requires otherwise:

(1) Board" or "board of commissioners" means the governing body of a district.

(2) "By-product" means any mineral or minerals (exclusive of oil, hydrocarbon gar. helium or other hydrocarbon substances, which are found in solution or in association with geothermal resources and which have a value of less than 75 percent of the value of the geothermal resounces or are not, because of quantity, quality, or technical difficulties in extraction and production, of sufficient value to warrant extraction and production by themselves.

(8) "District" means a geothermal beating district formed under this chapter.

(4) "County" means the county in which the district, or the greater portion of the tacrable assessed value of the district, is located.

(5) "County board" means the county count or boand of county commissioners of the county.

(6) "Coumty clerk" means the county clerk of the county.

(7) "Geothermal heat" means heat derived from geothermal resources.

(8) "Geothermal resources" means the natural heat of the earth, the energy, in whatever form, below the surface of the earth present in, resulting from, or created by, or which may be extracted from, the natural heat, and all minerals in solution or other products obtained from naturally heated fluids, brines, associated gases, and steam, in whatever form, found below the surface of the earth, exclusive of oil, hydrocarbon gas, helium or other hydrocarbon substances, but including, specifically:

(a) All products of geothermal processes, embracing indigenous steam, hot water and hot brines;

(b) Steam and other gases, hot water and hot brines resulting from water, gas or other fluids artificially introduced into geothermal formations;

(c) Heat or other associated energy found in geothermal formation; and

(d) Any by-product derived from them.

(9) "Inhabitant" when used with respect to a district includes a business located within the district:
(10) "Owner" means the holder of the recound title to real property or the vendee under a land sale contract, if there is such a contract.

(11) "Voter" means a registered voter of the state who resides in the district or proposed district.

[1975 c.782 81]

523.015 Definitions for 523.020 For the purposes of ORS 523.020 and this section, notwithstanding ORS 523.610 to 523.670 , "board," as defined in ORS 523.010, includes the governing body of a city. "District," as defined in ORS 523.010, includes an incorporated city.

[1977 c.212 81]

Note: 523.015 and 623.020 were enacted into law by the Legislative Assembly but were not added to or made a part of ORS chapter 523 or any weries therein by legislative action. See the Preface to Oregon Revised Statutes for further explanation.

\section{CREATION AND POWERS -}

523.020 City as geothermal heating district. (1) An incorporated city, when empowered by its charter to do so, may provide geothermal heating services to persons within and without its boundaries in acoordance with the provisions of this chapter, where not in conflict with ORS 523.015 and this section.

(2) The powers conferred by this chapter and ORS 523.015 and this section are in addition to the powers conferred by any other law and not in substitution for any right, power or privilege vested in a city.

[1977 c212 82]

Notes See note under 523.015 .

523.030 Incorporation of geothermal heating districts; disposal of surplus; exclusion from district. Communities may be incorporated for the purpose of supplying their inhabitants with geothermal heat as provided by this chapter; and, in connection therewith, may supply, furnish and sell for any use any surplus geothermal heat over and above the heating needs of its inhabitants to any persons, corporations or associations, either within or without the district, or to other communities or municipal corporations. All railroad rights of way or improvements thereon or rolling stock moving thereover shall be excluded from districts organized under ORS 198.010, 198.180, 198.520, $198.710,199.420,259.020,366.321,451.573$ and this chapter and for purposes of this 
chapter shall not be considered as property within the boundaries of such districts, unless the owner of the railroad property expressly consents to its inclusion.

[1975 c.782 82]

523.040 Powers of district; emergency power; applying for financing gifts and grants. (1) A district formed under this chapter shall have the power to make contracts, hold and receive and dispose of real and personal property within and without its described boundaries and do all other acts and things which may be requisite, necessary or convenient in carrying out the objects of the district or exercising the powers conferred upon it by this chapter, sue and be sued, plead and be impleaded in all actions and suits or other proceedings brought by or against it.

(2) In an emergency or in order to meet peak demand a district may supply its inhabitants with heat derived from an energy sounce other than from geothermal resources for purposes of supplementing the geothermal heat supplied by the district.

(3) In addition to any other power of a district, it may apply and qualify for and receive any private or federal grants; loans of other funds available for carrying out the bbjects of the district.

[1975 e.782 \$3]

523.050 Water and real property transactions; right to obtain geothermal heat from other sources. A district may purchase, sell and hold interests in water and real property in carrying out the objects of the district. A district also has the right to purchase or obtain from other cities or like corporations, geothermal heat, or an interest in geothermal heat, or an interest in a geothermal heat pipeline owned or operated by any such city or like corporation, or to obtain jointly with any such city or like corporation, any right, or to lay and own individually or jointly with any city or like corporation, any geothermal heat pipeline for the purposes specified in ORS 523.030.

[1975 c.782 \$5]

523.060 Cooperative agreements; bonds. (1) Districts may enter into cooperative agreements with each other providing for the joint acquisition, construction, ownership, use or control of facilities for the collection, treatment, distribution or supply of geothermal heat.

(2) Each district may issue and sell general obligation, revenue or refunding bonds, subject to the limitations and procedures contained or referred to in this chapter for the authorization, issuance or sale of such boinds, for the purpose of paying its share of the cost of the acquisition or construction of facilities provided for in cooperative agreemerits authorized by this section.

[1975 c782 818]

523.070 Authority to perform drainage work. Any district may perform drainage work for the purpose of reclaiming real property located within the district, protecting real or personal property located within the district from the effects of geothermal heating, promoting sanitation, providing for the public health, convenience and welfare or providing services of public utility or behefit. The district may use all applicable powers granted to it by. this chapter, including the rights and powers of eminent domain, in performing the drainage work authorized by this section.

[1975 c.782 \&17]

\section{OPERATION}

523.110 Regulations on use of geothermal heat; effect of failure to comply. Any distritt may adopt and promulgate regu: lations concerning the use of geothermal heat and the property of the district. The board of commissioners may refuse to supply diny building, place or premises with geothermal heat where the user fails after 10 days' written notice to comply with the regulations. The written notice shall be by registered mall and shall be deemed given when it is deposited it the United States Post Office properly dit dressed with postage prepaid.

[1975 c.782 \$11]

523.120 Deposit for use of heat Any district may require a reasonable cash deposit to insure payment for the use or rent of geothermal heat to be furnished by the distritt. [1975 c.782 §12]

523.130 Rates; contracts with users. A district shall charge consumers for the geothermal heat furnished and fix and collect the rates therefor. Rates charged may be fix'ed and classified according to the type of use athd according to the amount of geothermal heat used. Any contract entered into by a district with individuals, corporations or associations other than domestic users shall provide for immediate cancellation whenever no surplus supply of geothermal heat exists over and above any and all demands of domestic users. A district also may contract with other coin. 
munities, geothermal heat districts, individuals or corporations, private or municipal, to supply, furnish and sell them surplus geothermal heat on such terms and conditions and at such rates as the board of commissioners considers advisable.

[1975 c.782 \&13]

523.140 Rate increase procedure. (1) Whenever any increase is proposed in the existing rates charged geothermal heat consumens by a district pursuant to ORS 523.130 , the boand of commissioners shall first provide for a public hearing on such proposal before any increased rates are ordered into effect.

(2) The public hearing required under subsection (1) of this section shall be held at a place designated by the board after notice thereof has been given by inclusion of a notice of the public hearing in the geothermal heating bills sent to consumers by the district during the period of $\mathbf{3 0}$ days prior to the date of the bearing.

[1975 c782 814]

523.160 Termination of service for nompayment of beating charge. In case prompt payment of geothermal heating rent or charge is not made, a district may shut off the geothermal heating supply to the building, place or premises to which the district supplied the geothermal heating.

[1975 c.782 \&15]

523.160 Refind of heating service extension costs by owner of adjacent property. If any person is required by a district to pay the cost of extending a geothermal heating pipeline adjacent to property other than his own so that geothermal heating service is provided for such other property without further extension of the geothermal heating pipeline, the district shall require the owner of the other property, prior to providing geothermal heating service to that property, to refund to the person required to pay the cost of extending the geothermal heating pipeline, a pro rata portion of the cost of the extension. The right to require such refund shall not continue for more than 10 years after the date of installation of the extension of the geothermal heating pipeline. The amount to be refunded shall be determined by the district and such determination shall be final.

[1975 c.782 \&16]

\section{ASSESSMIENIS}

523.210 Special assessment for improvements; report; contents. Whenever the district boand considers it necessary, upon its own motion, or upon the petition of the owners of one-half of the property that benefits specially from the improvement, to make any improvement to be paid for in whole or in part by special assessment according to benefits, the board shall, by motion, cause a survey and written report for such project to be made and filed with the secretary. Unless the district board directs otherwise, the report shall contain:

(1) A map or plat showing the general nature, location and extent of the proposed irmprovement and the land to be assessed for the payment of any part of the cost thereof.

(2) Plans, specifications and estimates of the work to be done; however, where the proposed project is to be carried out in cooperation with any other governmental agency, the district board may adopt the plans, specifications and estimates of such agency.

(3) An estimate of the probable cost of the improvement, including any legal, administrative and engireering costs attributable thereto.

(4) An estimate of the unit cost of the improvement to the specially benefited properties.

(5) A recommendation as to the method of assessment to be used to arrive at a fair apportionment of the whole or any portion of the cost of the improvement to the properties specially benefited.

(6) The description and assessed value of each lot, parcel of land or portion thereof, to be specially benefited by the improvement, with the names of the record owners thereof and, when readily available, the names of the contract purchasens thereof.

(7) A statement of outstanding assessments against property to be assessed.

[1975 c.782 819]

523.220 Action on special assessment report by board. After the report has been filed with the secretary, the district board may by motion approve the report, modify the report and approve it as modified, require additional or different information for the improvement, or it may abandon the improvement.

[1975 c.782 820] 
523.230 Approval of epecial assessment report; notice of improvement; contents. After the district board approves the report as submitted or modified, the board shall, by resolution, declare its intention to make the improvement, provide the manner and method of carrying out the improvement and direct the secretary to give notice of the improvement. Such notice shall be given by two publications one week apart in a newspaper of general circulation within the district, and by mailing copies of the notice by registered or certified mail to the owners to be assessed for the costs of the improvement. The notice shall contain the following:

(1) That the report of the improvement is on file in the office of the secretary and is subject to public examination.

(2) That the district boand will hold a public hearing on the proposed improvement on a specified date, which shall not be earlier than 10 days following the first publication of notice, at which objections and remonstrances to the improvement will be heard by the boand; and that if prior to such hearing there shall be presented to the secretary valid, written remonstrances of the owners of two thinds of the property or two-thirds of the front footage of the property to be specifically affected for the improvement, then the improvement will be abandoned for at least six months, unless the improvement is unanimously declared by the district board to be needed at once because of an emergency.

(3) A description of the property to be specially benefited by the improvement; the owners of the property and the estimate of the urit cost of the improvement to be paid for by special assessments to benefited properties.

[1975 c.782 \$21]

523.240 Means of constructing improvement. The district boand may provide in the improvement resolution that the construction work will be done in whole, or in part, by the district, by a contract or by any other governmental agency, or by any combination thereof.

[1975 c.782 \$22]

523.250 Order to carry out or abandon improvement after public hearing; assessment ordinance. (1) At the time of the public hearing on the proposed improvement, if the written remonstrances represent less than the amount of property required to defeat the proposed improvement, if such an improvement is one that can be remonstrated against, then on the basis of such hearing of written remonstrances and oral objections, if any, the district board may, by motion, at the time of the hearing or within 60 days thereafter, order the improvement to be carried out in accordance with the resolution, or the district boand may, on its own motion, abandon the improvement.

(2) After the public hearing on the proposed improvement and after the district board has moved to proceed with the improvement, it may pass an ordinance assessing the various lots, parcels of land or parts thereof, to be specially benefited with their apportioned share of the cost of the improvement; but the passage of an assessment ordinance may be delayed until the contract for the work is let, or until the improvement is completed and the total cost thereof is determined.

[1975 c.782 \$23]]

523.260 Method of assessment The district boand in adopting a method of assessment of the costs of the improvement may:

(1) Use any just and reasonable method of determining the extent of any improvement district consistent with the benefits derived.

(2) Use any method of apportioning the sum to be assessed as is just and reasonable between the properties determined to be specially benefited.

(3) Authorize payment by the district of all, or any part, of the cost of any such improvement, when in the opinion of the board the topographical or physical conditions, or unusual or excessive public travel, or other character of the work involved warrants only a partial payment or no payment by the benefited property of the costs of the improvement.

[1975 c.782 \$24]

523.270 Appeal of assessment. Any person feeling aggrieved by the assessments made under an assessment ordinance may, within 20 days after the passage of the ordinance levying the assessment by the district board, appeal to the circuit court for the county in which the district is located. The appeal and the requirements and formalities thereof shall be heard, governed and determined, and the judgment thereon rendered and enforced, in the manner provided for appeals from assessments in ORS chapter 223. The result of the appeal shall be a final and conclusive determination of the matter of the assessment, except with respect to the district right of reassessment provided by ORS 523.360 .

[1975 c.762 \$25] 
523.280 Notice of assessment to property owners; publication; contents. Within 10 days after the ordinance levying assessments is adopted, the secretary of the district shall send by registered or certified mail a notice of assessment to the owner of the assessed property, and shall publish notice of the assessment twice in a newspaper of general circulation in the district, the first publication of which shall be made not later than 10 days after the date of the assessment ondinance. The notice of assessment shall recite the date of the assessment ordinance and shall state that upon the failure of the owner of the property assessed to make application to pay the assessment in instalments within 10 days from the date of the first publication of notice, or upon the failure of the owner to pay the assessment in full within 30 days after the date of the assessment ordinance, then interest will commence to run on the assessment and the property assessed will be subject to foreclosure. The notice shall also set forth a description of the property assessed; the natie of the owner of the property and the amount of each assessment. [1975 c782 826]

523.290 Entry of amount of assessment; lien; priority; foreclosure. After passage of the assessment ordinance by the district board, the secretary shall enter in the docket of district liens a statement of the amounts assessed upon each particular lot, parcel of land or portion thereof, together with a description of the improvement, the name of the owners and the date of the assessment ordinance. Upon such entry in the lien docket, the amcunt so entered shall become a lien upon the respective lots, parcels of land or portions thereof, which have been assessed for such improvement. All assessment liens of a district shall be superior and prior to all other liens or encumbrances on property in so far as the laws of the state permit. Interest shall be charged at the rate of six percent per annum until paid on all amounts not paid within 30 days from the date of an assessment ordinance. After expiration of $\mathbf{3 0}$ days following the date of an assessment ordinance the district may proceed to foreclose or enforce collection of the assessment liens in the amount provided by the general law of the state. However, the district may, at its option, enter $a$ bid for the property being offered at a foreclosure sale, which bid shall be prior to all bids except those made by persons who would be entitled under the laws of the state to redeem the property.

[1975 c782 \$27]
623.310 Errors in assessment. Claimed errors in the calculation of assessments shall be called to the attention of the cecretary of the district, who shall determine whether there has been an error in fact. If the secretary finds that there has been an error in fact, he shall recommend to the district board an amendment to the assessment ordinance to correct the error. Upon enactment of the amendment, the secretary shall make the necessary correction in the lien docket and send a correct notice of assessment by registered or certified mail.

[1975 c.782 828]

523.320 Deficit assessment; hearing; objections; notices. In the event that an assessment is made before the total cost of the improvement is ascertained, and if it is found that the amount of the assessment is insufficient to defray the expenses of the improvement, the district board may, by motion, declare such deficit and prepare a proposed deficit assessment. The board shall set a time for a hearing of objections to such deficit assessment and shall direct the secretary to publish one notice thereof in a newspaper of general circulation in the district. After the hearing the boand shall make a just and equitable deficit assessment by ondinance, which shall be entered in the lien docket as provided by ORS 523.210 to 523.380. Notices of the deficit assessment shall be published and mailed and the collection of the assessment shall be made in accordance with ORS 523.280 and 523.290.

[1975 c782 820]

623.330 Excess assessment; credit; rebate Upon the cumpletion of the improvement project, if it is foumd that the assessment previously levied upon any property is more than sufficient to pay the costs of the improvements, the district boand shall ascertain and declare the amount of the excess by ordinance. When declared, the excess amounts shall be entered on the lien docket as a credit upon the appropriate assessment. If any assessment has been paid, the person who paid it, or his legal representative, shall be entitled to the repayment of the rebate credit, or the portion thereof which exceeds the amount unpaid on the original assessment.

[1975 c.782 830]

523.340 Abandonment of improvement; cancellation of liens; refunds. The district board may ubandon proceedings for an improvement at any time prior to the final completion of the improvement. If liens have been assessed upon any property under ORS 
523.210 to 523.380 , they shall be canceled, and any payments made on such assessments shall be refunded to the person paying the same, his assigns or legal representatives. [1975 c.782 \$31]

523.350 Restriction on rendering as. sessment invalid; correction by board. No improvement assessment shall be rendered invalid by reason of a failure of the improvement report to contain all of the information required by ORS 523.210 , or by reason of a failure to have all of the information required to be in the improvement resolution, the ussessment ordinance, the lien docket or hotlces required to be published and mailed, hor by the failure to list the name of, or mail notice to, the owner of any property as requiled by ORS 523.210 to 523.380 , or by reason of any other error, mistake, delay, otnission, irregularity or other act, jurisdiction br otherwise, in any of the proceedings or steps specified, unless it appears that the assessment is unfair or unjust in its effect upon the person complaining. The district board may remedy and correct all such matters by suitable action and proceedings.

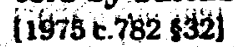

523.360 Reassessment. Whenever any assessment, deficit assessment or reassessment for any improvement which has boen made by the district is set aside, or its enforcement restrained by any court having jursidiction thereof, or when the district boand is in doubt as to the validity of an assessment, deficit assessment or reassessment, or any part thereof, the district board may make a reassessment in the manner provided by ORS 223.405 to 223.485 .

[1975 c.782 §33]

523.370 Application of certain provisions of ORS chapters 223 and 287 to assessments. If the cost, or any portion of the cost, of an authorized improvement is assessed against the property directly benefited, the provisions of ORS 223.205 to 223.300 in regard to the payment of assessments in instalments, the provisions of ORS 223.770, relating to the assessment of public property benefited by public improvements for the cost of such improvements, and the provisions of ORS 287.502 to 287.510 , relating to the issuance of improvement warrants by cities, shall apply in so far as practicable and applicable in the district. Where, in ORS 223.205 to $223.300,223.770$ and 287.502 to 287.510 officials of cities are referred to, the corre. sponding officials of districts where applicable shall perform the required functions. [1975 c.782 334]

523.380 Foreclosure of assessment lien. (1) In case the whole or any portion of the cost of an improvement is assessed against the property directly benefited and the owner of the property fails to pay the amount of the lien, or any portion thereof, or the interest thereon, when they become due, the board may proceed to foreclose the lien in any manner provided by law for the collection of liens by municipalities and may provide by ordinance a general procedure for the collection of liens in any manner not inconsistent with law.

(2) The provisions of ORS 223.405 to 223.485 relating to reassessment shall be available to districts where applicable.

[1975 c782 635]

\section{TAXING POWER}

523.410 Ad valorem taxation; spectal tax; collection; enforcement. (1) A distritt may assess, levy and collect taxes in ah athouint each year not to exceed one-fourth of one percetit (.0025) of the true cash value of all taxable property within the limits of the district, computed in accordance with ORS 308.207. The proceeds of the tax shall be applied by it in camying out the objects and purposes of ORS 523.030 to 523.050 and 523.420 to 523.490 and for the purpose of financing the employes' retirement system.

(2) A district may annually also assess, levy and collect a special tax upon all sich property in an amount sufficient to pay thie yearly interest on bonds theretofore lscued by the district and then outstanding, together with any portion of the principal of such bonds maturing within the year. The special tax shall be applied only in payment of interest and principal of bonds issued by the district, but the district may apply any funds it may have toward payment of principal and interest of any such bonds. If the bonds are registered with a county treasurer under ORS 208.200, the officer who collects the special tax shall transfer the proceeds to the county treasurtet referred to in ORS 523.460. If the district bond fund is not sufficient for this purpolse, the district shall transfer to the county treasurer any additional funds it has as required to pay the principal and interest of any such bonds.

(3) Taxes shall be levied in each year and retumed to the county officer whose duty it is 
to extend the tax roll by the time required by law for city taxes to be levied and returned.

(4) Taxes levied by the district shall become payable at the same time and be collected by the same officer who collects county taxes, and except as otherwise provided in subsection (2) of this section, the proceeds shall be turned over to the district according to law. The county officer whose duty it is to extend the county levy shall extend the levy of the district in the same manner as city taxes are extended.

(5) Property is subject to sale for nonpayment of taxes levied by the district in like manner and with like effect as in the case of county and state taxes.

[1975 c 782 \&10]

523.420 Disposal of taxes levied by invalid district. When an attempt has been made to organize a district under the provisions of this chapter and aubsequently by a decree of a court of competent jurisdiction it has been declared that the organization is invalid, but prior to such decree the invalid organization has levied taxes, the funds derived from the levy shall be disposed of as follows:

(1) If the area embraced in the invalid onganization is embraced in a subsequently created organization composed of unincorporated or incomporated territory, or combinations thereof, for the purpose of furnishing geothermal heat to the inhabitants thereof, the custodian of the taxes collected for the invalid organization shall turn them over to the subsequent organization to be used only for the purpose of furnishing geothermal heat to such inhabitants.

(2) If the subsequent organization does not embrace all territory embraced in the invalid organization, such taxes as have been collected from the levy upon property in areas not embraced in the subsequent organization shall be refunded to the payers thereof by the custodian of the taxes before the balance is turned over to the subsequent organization.

(3) If no such subsequent organization is created to provide geothermal heat for the inhabitants of such an area, within a period of two years after the entry of the decree of invalidation, the taxes collected shall be refunded by the custodian of them to the taxpayers who paid them.

[1975 c.782 84]

\section{BONDS}

523.460 General obligation bonds; limit; issuance; maturity; interest; election; pledge of revenue. (1) For the purpose of carrying into effect all or any powers granted by this chapter, the district, when authorized at any properly called election held for that purpose, may borrow money and sell and dispose of general obligation bonds. Except as otherwise provided by this section, the bonds shall never exceed in the aggregate two and one-half percent of the true cash value of all taxable property within the limits of the district, computed in accordance with ORS 308.207.

(2) The bonds shall be issued from time to time by the boand of commissioners in behalf of the district as authorized by the voters, and may be issued in an amount not to exceed one-half of one percent of the true cash value referred to in subsection (1) of this section without the approval of the voters. The bonds shall mature gerially within not to exceed $\mathbf{3 0}$ years from issue date, in like manner as bonds issued under authority of ORS 287.008, and shall bear interest not exceeding seven percent per annum payable semiannually as the board shall determine. The bonds shall be so conditioned that the district agrees to pay to the bearer at a place named, which may be at the office of the county treasurer of the county in which proceedings for formation of the district were conducted, the principal sum, with interest at the rate named, payable semiannually, in accordance with the tenor and terms of the interest coupons attached. Each bond payable at the office of the county treasurer shall be signed by, and registered in accordance with ORS 208.200 in the office of, the county treasurer referred to in this subsection.

(3) If the district has within its corporate limits a population of 300 or over, it may issue bonds in an amount which shall not exceed in the aggregate 10 percent of the true cash value referred to in subsection (1) of this section.

(4) For the purpose of additionally securing the payment of the principal and interest on general obligation bonds issued under this section, the district may, by resolution of its board which shall constitute part of the contract with the holders of the bonds, pledge all or any part of the net revenue of its geothermal heating system. The board may adopt such a resolution without submitting the 
question of the pledge to the voters of the district.

[1975 c.782 86; 1977 c.188 \&7]

523.470 Revenue bonds; terms; issuance. In addition to the authority to issue general obligation bonds, the district, when authorized at any properly called election, shall have the power to sell and dispose of revenue bonds, and to pledge as security therefor all or any part of the unobligated net revenue of the district or system, to purchase, acquire, lay out, construct, reconstruct, extend, enlarge or improve a geothermal heating system, for the purpose of obtaining geothermal heating for the use of consumers, within or without the boundaries of the district. The revenue bonds shall be issued in the same manner and form as are general obligation bonds of the district, but they shall be payable, both as to principal and interest, from revenues only, as specified by this section. The revenue bond shall not be subject to the percentage limitation applicable to general obligation bonds and shall not be a lien upon any of the taxable property within the corporate limits of such district, but shall be payable solely from such part of the revenues of the district as remain after payment of obligations having a priority and of all expenses of operation and maintenance of the district, including any taxes levied against it. All revenue bonds shall contain a clause reciting that both the principal and interest are payable solely from operating revenues of the district remaining after paying such obligations and expenses.

[1975 c.782 \$7]

523.480 Refunding bonds. Refunding bonds of the same character and tenor as those replaced thereby may be issued pursuant to a resolution duly adopted by the boand of commissioners without submitting to the voters the question of authorizing the issuance of such bonds.

[1975 e.782 \$8]

523.490 Advertising and sale of bonds. All general obligation and revenue bonds, including refunding bonds, issued under ORS 523.460 to 523.480 shall be advertised and sold in the manner prescribed in ORS 287.002 for the sale of bonds of cities of this state.

[1975 c.782 \$9]

\section{DISSOLUTION}

623.510 Assumption of debts and obligations of district upon dissolution. (1) A city may enter into a written agreement with a geothermal heating district contemplating dissolution undertaking to assume, in the event of such dissolution, all of the outstanding debts and obligations of the district and to continue to furnish geothermal heat to the inhabitants of the dissolving district for domestic and municipal use for a term therein specified, not to exceed 25 years. Subject to the provisions of this section, the sucoessor city shall, if the dissolution is approved, have the powers and assime the responsibilities of geothermal heating districts under this chapter. Any person entitled to geothermal heating service within the area of the dissolved dis. trict has the same remedies at law or in equity to enforce his rights to geothermal heating service as are available to enforce the right to geothermal heating service within the district.

(2) The successor city or district shall furnish geothermal heat to persons owning or occupying property within the dissolved district on the same terms and conditions as in the case of those owning or occupying property within the city, or elsewhere within the district. If the district assets and obligations are transferred to a city, the city may charge a rate for the service that is no more than the rate which is uniformly applied to all users in similar classifications outside the city. No such differential rate may be charged, however, unless such a differential is provided for, and specifically limited, by the terms of the agreement made prior to the dissolution. Nothing in this section authorizes a city to levy an ad valorem real property tax on property outside the city or district.

(3) Any debts or obligations assumed by the successor city by reason of, or duning the period of, its commitment under the agreement shall bind the city until they are fully paid and discharged. No contract shall be effective unless all of the terms thereof are reduced to writing, signed by the entities and filed with the county clerk.

[1975 c. 782 \$47]

\section{ADMINISTRATION}

523.610 Board; election; power; term; organization. (1) Except as otheruise provided by this chapter, the power and authority given to districts is vested in and shall be exercised by a boand of five commissioners, each of whom shall be a qualified voter within 
the district. Except as provided by subsection (2) of this section, each commissioner shall be elected for a term of four years.

(2) Within 10 days after the formation of a district and the election of the members of the first boand, the commissioners shall meet and organize, first taking and subscribing an oath of office. The commissioners first elected shall determine by lot the length of term each shall hold office. The term of one commissioner shall expire the next July 1 following his election, and the terms of the other four shall expire one in one year, one in two years and two in three years after the next July 1 following their election.

[1975 c.782 836]

523.620 Election. A regular election shall be held in the district each year, on the date fixed by ORS 259.240, for the election of one or more commissioners to sucoeed any commissioner whose term expires the following July 1 , and to elect commissioners to fill any vacancy which then may exist. [1975 C.782 537$]$

623.630 Meetings; officers; quorum; enployes; employe benefits. (1) The boand of commissioners shall hold meetings at such time and place within the district as it may determine. The boand shall hold at least one regular meeting in each month on a day to be fixed by it, and may hold opecial meetings under such rules as it may make.

(2) The board shall, at the time of its organization, choose from the commissioners a president, a secretary and a treasurer, who shall hold their offices until the first regular meeting in January, or until their successors are elected and qualified. The officers shall have, respectively, the powers and shall perform the duties usual in such cases. A majority shall constitute a quorum to do business and, in the absence of the president, any other member may preside at a meeting.

(3) The board of commissioners may employ engineers, superintendents, mechanics, clexks or other persons as it may find requisite, necessary or convenient in carrying on any work of the district and at a rate of remuneration as it may consider just.

(4) The board may provide life insurance and retirement or pension plans for employes of a district, if the insurer issuing the policy is licensed to do business in the State of Oregon. [1975 c.782 839]

523.640 Special election. The board of commissioners at any regular meeting may call a special election of the voters of the district. [1975 c.782 \$38]

523.650 Initiative and referendum In the exercise of initiative and referendum powers reserved under the Constitution of this state to the voters of every municipality and district as to all local, special and municipal legislation of every sort and character in and for their respective municipalities and districts, the general laws of the state as applied to cities and towns shall govern in geothermal heating districts, except that the measures referred by the board of commissioners shall be filed with the secretary not less than $\mathbf{3 0}$ days before the election at which they are to be voted upon. The chairman of the boand shall act as mayor and perform his duties, the secretary shall perform the duties of auditor or recorder, the attorney shall perform the duties of city attorney, and if there is no attorney, the secretary shall perform the duties required of the attorney. [1975 c.782 \$40]

623660 District funds; deposit; records. (1) Except as otherwise provided by . ORS 523.410, the money of a district shall be deposited in one or more banks, to be designated by the board of commissioners. The money shall be withdrawn or paid out only when previously ondered by vote of the boand, and upon checks signed by the treasurer or such other person as may be authorized by resolution of the board. Receipts or vouchers, showing clearly the nature and items covered by each check drawn, shall be kept on file.

(2) All the proceedings of the board of commissioners shall be entered at lange in a record book. All books, maps, plans, documents, correspondence, vouchers, reports and other papers and records pertaining to the business of the district shall be carefully preserved and shall be open to inspection as public records.

\section{[1975 c.782 \$41]}

523.670 Agreements between district and annexed city. If a city has been annexed to a district under ORS 198.865 , the city and the district may:

(1) Enter into contracts and agreements to do any act or thing which either could have done if the annexation had not occurred.

(2) Contract and agree for the collection by the district of any geothermal heat tax or charge imposed by the city upon geothermal heat users within the territory of the city, and the district thereupon may provide for such 
collection according to its rules and regulations for the collection of amounts due the district by geothermal heat users, including but not limited to shutting off the geothermal heat supply for nompayment. [1975 c.782 842]

523.680 Employes' retirement system; establishment; contents. (1) A district may establish an employes' retirement system. The board of commissioners may enter into agreements necessary to establish the system and carry out the plan and may agree to modifications of such agreements from time to time.

(2) The retirement plan may provide for retirement benefits measured on the basis of services rendered or to be rendered by an employe, either before or after the date on which such employe first becomes a member of the retirement plan. The retirement plan may provide for a minimum of years of service and a minimum and maximum age of retirement for the employe.

[1975 c.782 \$43]

523.690 Payments to retirement plan fund. The district may budget and provide for payment into the fund of the retirement plan an amount sufficient:

(1) To provide on an actuarial reserve basis the amortized level premium cost of the retinement benefits which, under the provision of the retirement system, are to be pro- vided by the district to its employes who attain the retirement age or retire in accordance with the terms of the retirement plan.

(2) To meet the actuarially computed costs of retirement benefits measured on the basis of services rendered or to be rendered by an employe before or after the date on which such employe becomes a member of the retirement plan.

[1975 c.782 844]

523.700 Employe contributions to retirement plan. The district may collect, as a contribution from any ermploye, that percentage of the salary received by the employe which is necessary to fund on an actuarial reserve basis the cost of retirement benefits which the employe is required to provide pursuant to the provisions of a retirement plan.

[1975 c.782 \$45]

523.710 Limit on eligible individuals in retirement plan. Nothing in this chapter authorizes the district to budget, provide for payments or collect contributions to fund retirement benefits for an individual who is not in the employment of the district at the time of the creation of a membership status under a retirement plan.

[1975 c.782\$46]

\section{CERTIFICATE OF IEGISLATTVE COUNSEL}

Pusuant to ORS 173.170, I. Thomas G. Clifford, Legislative Counsel, do hereby certify that I have compared pach section printed in this chapter uith the original section in the enrolled bill, and that the sections in this chapter are correct copies of the enrolled sections, with the exception of the changes in form permitted by ORS 173.160 and other changes specifically authorized by law.

Done at Salem. Oregon.

Thomas G. Clifford October 1,1977.

CHAPTERS 524 AND 525

[Reserved for expansion] 


\title{
Chapter 522
}

\author{
1977 REPLACEMENT PART
}

\section{Geothermal Resources}

\author{
GENERAL PROVISIONS \\ 622005 \\ 520015 \\ 502025 \\ 692035 \\ 502045 \\ Definitions \\ Pollicy \\ Application \\ Ownership rights \\ Abandoned well; juriodiction
}

\section{PROSPECT WHIS}

602055 Permit; application; foe

52006

Circulation of application to tate agencies; augrested conditions to permiti time limit for permit action

50207s Bond or ecurity; exscution; cancellation; waiver

520085 Report certifying completion of abandon. ment plan

\section{GEOTHERMAL WELS}

522.115 Permit; application; fee

522.125 Circulation of application to tate agen. cles; euryested conditions to permit

522.135 Permit; time limit for sction; grounds for isousance; conditions; condruction of permit

522145 Bond or security; execurtion; cancellation; vraiver

522.155 Lablity for failure to protect ground water tandards for protection of pround and curface vater

622165 Location, number, or designation changes alteration of casing

622.175 Abandonment proceedings egainst operator for unlawful abandonment

522.185 Production and abandonment bond; cancellation; completed well

622195 Monthly production statement

622205 Transfer or purchnse of well; notice; application; fee; notice by landowner of transfer or purchase
622215

502025

502235

522245

$\cos 275$

602005

502815

6202925

202355

522365

522810

522815

520010

622915

202990
Suspension of drilling or operation; application; terms; extension; presump tion of abandonment unlawful abandoament; notice; proceedings against operator

Notice of intent to abandon

Conditions precedent to abandonment

Department approval of abandonment; report by operator; effect of fallure to comply; proceedings against operator

\section{'ADMINISTRATION}

\section{Administration by State Coolorist}

Rules

Final onder of department delivery to operator

Compliance with final order, appeal

\section{WETL RECORDS}

Records of well; contents; drill cultings and core sampies

Filing recond with department; exemption from disclosure

\section{ENFORCENIENT}

Suits to enjoin violations

Orders by board; woope, notice; hearing

\section{PROHIBITED ACTS}

Alding in violations prohibited

False entries, cmissions, destruction, or removal of records or reports

\section{PENALTIES}

Penalties

\section{CROSS REFERENCES}

Alr and water pollution control permit for geothermal well drillings and operation, 468.350

Assessment of lands subject to geothermal resource exploration leases for ad valorem taxation, 308.370
Explaration, mining and processing of geothermal resouroes in aneas zoned for farm use, 215.213

Ceothermal resource rights on state lands, 273.780 


\section{GENERAL PROVISIONS}

522.005 Definitions. As used in this chapter, unless the context requires otherwise:

(1) "Boand" means the governing board of the State Department of Geology and Mineral Industries.

(2) "Byproduct" means any mineral or minerals, exclusive of helium or of oil, hydrocarbon gas or other hydrocarbon substances, which are found in solution or in association with geothermal resources and which have a value of less than 75 percent of the value of the geothermal resource or are not, because of quantity, quality, or technical difficulties in extraction and production, of sufficient value to warrant extraction and production by themselves.

(3) "Department" means the State Department of Geology and Mineral Industries.

(4) "Drilling" includes drilling, redrilling and deepening of a geothermal well.

(5) "Geothermal area" means any parcel of land that is, or reasonably appears to be, underlaid by geothermal resources.

(6) "Geothermal well" includes any excavation 500 feet deep or more made for discovery or producing geothermal resources.

(7) "Geothermal resources" means the natural heat of the earth, the energy, in whatever form, below the surface of the earth present in, resulting from, or created by, or which may be extracted from, the natural heat, and all minerals in solution or other products obtained from naturally heated fluids, brines, associated gases, and steam, in whatever form, found below the surface of the earth, exclusive of helium or of oil, hydrocarbon gas or other hydrocarbon substances, but including, specifically:

(a) All products of geothermal processes, embracing indigenous steam, hot water and hot brines;

(b) Steam and other gases, hot water and hot brines resulting from water, gas, or other nuids artificially introduced into geothermal formations;

(c) Heat or other associated energy found in geothermal formations; and

(d) Any byproduct derived from them.

(8) "Operator" means the person:

(a) Who possesses the legal right to drill a geothermal well;

(b) Who has obtained a drilling permit pursuant to ORS E22.135; or (c) Who possesses the legal right to operate a completed geothermal well as described by ORS 522.185.

(9) "Prospect well" includes any well drilled as a geophysicial test well, seismic shot hole, mineral exploration drilling, core drilling or temperature gradient test well, less than $\mathbf{5 0 0}$ feet in depth, and drilled in prospecting for geothermal resources. "Prospect well" does not include a geothermal well as defined in subsection (6) of this section.

(10) "Waste" means any physical waste, including but not limited to underground waste resulting from the inefficient, excessive or improper use or dissipation of reservoir energy or resulting from the location, spacing, drilling, equipping, operation or production of a geothermal resource well in such a manner that reduces or tends to reduce the ultimate economic recovery of the geothermal resouroes within a reservoir; and surface waste resulting from the inefficient storage of geothermal resources and the location, spacing, drilling, equipping, operation or production of a geothermal resounve well in such a manner that causes or tends to cause the unnecessary or excessive surface loss or destruction of geathermal resounces released from a reservoir.

[1975 c.552 83]

\$22.010 [1971 c.776 \$2; 1973 c.388 \$1; repealed by 1975 c.552 855]

522.015 Policy. (1) The Legislative Assembly hereby finds and declares that:

(a) The people of the State of Oregon have a direct and primary interest in the development of geothermal resources situated in this state.

(b) The State of Oregon, through the State Department of Geology and Mineral Industries, shall control the drilling, redrilling and deepening of wells for the discovery and production of geothermal resources so that such wells will be constructed, operated, maintained and abandoned in the manner necessary to safeguard the life, health, property and welfare of the people of this state, to safeguard the air, water and other natural resources of this state, and to encourage the maximum economic recovery of geothermal resources therefrom.

(2) It is the policy of the Legislative Assembly that this chapter be administered:

(a) To prevent damage to and waste of geothermal resources; 
(b) To prevent interference with or damage to waters used or to be used for beneficial purposes that may result from improper drilling, operation, maintenance or abandonment of geothermal or prospect wells; and

(c) To supervise the drilling, operation, maintenance and abandoment of geothermal or prospect wells in a manner permitting the operator to utilize all methods known to the industry for the purpose of increasing the ultimate economic recovery of geothermal resources, that are suitable, and consistent with protection of the air, water and other natural resources of the state.

[Formerly 522.050]

Note HJR 50 (1977), provides:

Whereas geothermal resources present an economical sounce of energy; and

Whereas geothermal resources, if properly utilized, could be of great benefit to Oregon; and

Whereas geothermal resounces must be developed in a systematic and coordinated manner in order to maximire economic benefit and minimize possible damage to the environment; and

Whereas there must be an ecologically safe and conomically viable means of disposing of geothermal nuids; and

Whereas the surface disposal of geothermal nuids is currently the subject of scientific inquiry; and

Whereas the type of system used to dispose of geothermal fluids must be adapted to local geological and environmental conditions; and

Whereas improper disposal of geothermal nuids may result in serious environmenital detriment; and

Whereas the State of Oregon presently does not have a policy on the regulation of geothermal fluid disposal and

Whereas there ane presently at least four state agencies which have some involvement in the regulation of geothermal resources, and

Whereas a coordinated effort among these agencies is necessary in order to assure proper regulation which best serves Oregon; now, therefore,

Be It Resolved by the Legislative Assembly of the State of Oregon:

(1) The Water Resources Department, Department of Envinonmental Quality, State Department of Geology and Mineral Industries and Department of Energy are directed to make a cooperative and coondinated effort to establish a policy and, if necessary, promulgate rules on the disposal of geothermal nuids. Any rules proposed as a result of this effort shall be sufficiently nexible to promole economically beneficial and envirunmentally safe use of geothermal resounces.

(2) The dinctors of these agencies shall submit joint report to the Sirtieth Legislative Aswembly on the progress they have made toward this goal. The report may include a reconmendation for new legislation.

(3) A copy of this resolution shall be transmitted to the Governor, the Water Resources Director, the Director of the Department of Enviranmental Quality, the State Ceologist and the Director of the Department of Energy.

622020 [1971 c.776 \$32; repealed by 1975 c552 \$55]

522.025 Application. The provisions of this chapter relating to the location and drilling of any well for the production of geothermal resources do not apply to any wells producing geothermal resources on July 1,1975 , or wells, other than prospect wells, drilled to a depth no greater than 2,000 feet where:

(1) The geothermal nuids produced are of less than 250 degrees Fahrenheit bottom hold temperature; or

(2) Such fluids have been appropriated pursuant to ORS 537.505 to 537.795.

[1975 c.552 84]

522.035 Ownership rights. Ownership rights to geothermal resources shall be in the owner of the surface property underlain by the geothermal resources unless such rights have been otherwise reserved or conveyed. However, nothing in this section shall divest the people or the state of any rights, title or interest they may have in geothermal re sources.

[1975 c.552 \$21]

522.045 Abandoned well; jurisdiction Any well drilled under authority of this chapter from which usable geothermal resources cannot be derived, or the owner or operator has no intention of deriving usable geothermal resources, shall be plugged and abandoned as provided in this chapter or, upon the operator's written application to the department and with the concurrence and approval of the Water Resources Director, jurisdiction over the well may be transferred to the Water Resources Director and, in such case, the well shall no longer be subject to the provisions of this chapter but shall be subject to any applicable laws and rules relating to wells drilled for appropriation and use of ground waters. If an application is made to transfer jurisdiction, a copy of all logs, records, histories and descriptions shall be provided to the Water Resources Director by the applicant.

[ 1975 c.552 \&4e]

522050 [1971 c.776 \$1; 1975 c 552 \$1; renumbered 522.015 


\section{PROSPECT WELLS}

622055 Permiti application; fee.

No person shall engage in drilling a prospect well without first obtaining a permit issued under the authority of the State Ceologist and without complying with the conditions of such permit.

(2) An application to drill prospect wells shall contain such information as the department may require, and shall be accompanied by a fee set by the department but not to exceed \$200 to cover all prospect wells included within the application.

[1975 c.552 4a]

522.060 [1971 c776 \$34; repealed by 1975 c.552 \$55]

522.065 Circulation of application to state agencies; suggested conditions to permit; time limit for permit action. (1) Upon receipt of an application to drill prospect wells, the State Geologist shall circulate copies of the application to the Water Resources Director, the Director of the Department of Environmental Quality, the Director of the Department of Land Conservation and Development, and the Director of the Division of.State Lands.

(2) Any public agency desiring to suggest conditions under which a permit should be granted shall provide such information to the department within 15 days of receipt of the copy of the application.

(3) Except as provided in ORS 522.075, within 30 days of receipt of an application to drill prospect wells, the State Geologist shall grant a permit to drill, subject to such conditions as he may impose. Included among the conditions shall be provision for the proper and safe abandonment of each prospect well. [1975 c.552 54b]

522.070 [1971 c.776 \$7; repealed by 1975 c.652 \$55]

522.075 Bond or security; execution; cancellation; waiver. (1) No permit for prospect wells shall be granted until the applicant has filed with the department a bond or security deposit in the surn of $\$ 5,000$ for all prospect wells which are included within the application and to be drilled by the applicant.

(2) The bond or deposit shall be conditioned upon compliance with the requirements of this chapter, rules adopted and orders issued pursuant thereto, which shall secure the state against all losses, charges and expenses incurred by it in obtaining such compliance.
(3) The bond provided for in subsection (1) of this section shall be executed by the applicant, as principal, and shall meet such conditions as the boand by rule may establish.

(4) With the consent of the board, any bond submitted as required by this section may be terminated and canceled and the surety be relieved of all obligations thereunder. However, the boand shall not consent to the termination and cancellation of any bond until the prospect wells described by such bond have been properly and safely abandoned pursuant to the abandonment plan required by the permit or another valid bond for the prospect wells has been submitted and approved by the boand.

(5) For those applications concerning prospect wells on federal lands, the board may waive the requirements of subsections (1) to (4) of this section upon receipt of suitable proof of compliance by the applicant with federal bond requirements which would, in the opinion of the board, be unnecessarily duplicated by the requirements of this section. [1975 c.552 \&4c; 1977 c 87 51]

522.085 Report certifying completion of abandonment plan. Upon completion of all drilling and testing undertaken pursuant to an application to drill prospect wells, the applicant shall file with the State Geologist a report certifying the completion of the abandonment plan required by the permit. [1975 c.552 \$4d]

522110 [1971 c.776 \$11; 1973 c.388 \$2; repealed by 1975 c.552 \$55]

\section{GEOTHERMAL WELLS}

522.115 Permit; application; fee (1) No person shall engage in the drilling or operating of any geothermal well without first obtaining a permit issued under the authority of the State Geologist, and without complying with the conditions of such permit.

(2) An application for a permit shall contain:

(a) The location and elevation of the floor of the proposed derrick.

(b) The number or other designation approved by the department by which the well shall be known.

(c) The applicant's estimate of the depths to be drilled.

(d) The nature and character of the geothermal resource sought. 
(e) Such other information as the board by rule may require.

(3) An application shall be accompanied by a nonrefundable fee of $\$ 100$.

(4) All fees collected by the department under this section shall be deposited with the State Treasurer and are continuously appropriated to the department for the administration of chapter 552, Oregon Laws 1975. [1975 c.552 85; 1977 c.87 82]

Note The Legislative Counsel has not, pursuant to 173.160, undertaken to substitute specific ORS references for the words "this Act" in 522.115 or 522.135. Chapter 552, Oregon Laws 1976, enacted into law and amended the ORS sections which may be found by referring to the 1975 Comparative Section Table located following the Index in volume 6 of Oregon Revised Statutes (1975 Replacement Parts).

522120 [1971 c.776 \$\$12, 13; 1973 c.388 \$3; repealed by 1975 c.552 (55]

522.125 Circulation of application to state agencies; suggested conditions to permit (1) Upon receipt of an application for a permit to drill or operate a geothermal well, the department shall circulate copies of the application to the Water Resources Director, the State Fish and Wildlife Director, the State Forester, the Director of the Department of Environmental Quality, the administrative officer of the State Soil and Water Conservation Commission, the State Parks Superintendent, the Water Policy Review Board, the State Highway Engineer, the Director of the Department of Land Conservation and Development, the Director of the Division of State Lands and the governing body of the county or counties in which the well or wells will be located.

(2) Any public agency desiring to suggest conditions under which a permit should be granted shall provide such information to the department within 30 days of receipt of the copy of the application.

[1975 c.552 \$6]

522130 [1971 c.776 \$14; repealed by 1975 c.552 \$55]

522.135 Permit; time limit for action; grounds for issuance; conditions; construction of permit. (1) Within 45 days after receipt of the application, the State Geologist shall by order issue, deny, suspend, modify, revoke or not renew a permit pursuant to this chapter and ORS chapter 183 except that appeal of any order issued pursuant to this section shall be made to the governing board of the State Department of Geology and Mineral Industries before any appeal under ORS 183.480 is allowed.
(2) The State Geologist may issue the permit if, after receipt of comments from the agencies referred to in ORS 622.125, he determines that issuance thereof would be consist. ent with the purposes set forth in ORS 468.280, 468.710 and 537.525, rules adopted pursuant to ORS 468.725, and the purposes of this chapter.

(3) If the State Geologist issues a permit pursuant to this section, he shall impose such conditions as he considers necessary to carry out the purposes set forth in ORS 468.280, 468.710 and 537.525 , rules adopted pursuant to ORS 468.725, and the purposes of this chapter. He shall include in the permit a statement that issuance thereof does not relieve any person from any obligation to obtain a permit under ORS 468.725 or 468.730 .

(4) The State Geologist shall incorporate into the permit requirements:

(a) Any conditions made by the Water Resources Director necessary to comply with the purposes set forth in ORS 537.525; and

(b) Any conditions made by the Department of Environmental Quality necessary to comply with the purposes set forth in ORS 468.280 and 468.710 .

(5) Nothing in chapter 552, Oregon Laws 1975 , shall be construed to excuse an operator of a geothermal well from complying with the provisions of the Federal Water Pollution Control Act amendments of 1972 (Public Law 92-500) or ORS 468.730 or to dilute the authority of the Department of Environmental Quality to issue National Pollution Discharge Elimination Systems Permits.

[1975 c.552 \$7]

Note: See note under 522.115

522.140 [1971 c.776 \$6; 1973 c.388 \$4; repealed by 1975 c.552 \$55]

522.145 Bond or security; execution; cancellation; waiver. (1) Except as waived by rule of the board, no permit shall be granted until:

(a) The applicant has filed with the department a bond or security deposit in the sum of $\$ 10,000$ for each well to be drilled; or

(b) The applicant to drill more than one geothermal well has filed with the department a bond or security deposit in the sum of $\$ 25,000$ for all wells to be drilled.

(2) The bond or deposit shall be conditioned upon compliance with the requirements of this chapter, rules adopted and orders 
issued pursuant thereto, which shall secure the state against all losses, charges and expenses incurred by it in obtaining such compliance.

(3) The bonds provided for in subsection (1) of this section shall be executed by the applicant, as principal, and shall meet such conditions as the board by rule may establish.

(4) With the consent of the board, any bond submitted as required by this section may be terminated and canceled and the surety be relieved of all obligations thereunder. However, the board shall not consent to the termination and cancellation of any bond until the geothermal well described by such bond has been properly completed or lawfully abandoned or another valid bond for the well has been submitted and approved by the board.

(5) For those applications concerning geothermal wells on federal lands, the board may waive the requirements of subsections (1) to (4) of this section upon receipt of suitable proof of compliance by the applicant with federal bond requirements which would, in the opinion of the board, be unnecessarily duplicated by the requirements of this section. [1975 c.552 \$8; 1977 c.87 \$3]

522.150 [1971 c.776 88; repealed by 1975 c.552 \$55]

522155 Liablity for failure to protect ground water; standards for protection of ground and surface water. (1) In addition to any other liability of the operator of a geothermal well, the operator shall be liable to any person or public agency that sustains damages from failure of the operator to comply with a condition in a permit requiring him to provide for the protection of ground water in the area affected by the well.

(2) The boand shall adopt by rule standands for blowout prevention, equipment and casing design and removal, and any other procedures necessary to shut out detrimental substances from strata containing ground or surface water usable for beneficial purposes. [1975 c.552 \$9]

522.160 [1971 c.776 \$18; repealed by 1975 c.552 \$55]

522.165 Location, number, or designation change; alteration of casing. (1) The location, number or designation specified for any geothermal well in a permit issued pursuant to ORS 522.135 shall not be changed without first obtaining written consent from the department.

(2) No operator shall alter in any manner the casing of a geothermal well without 406 notifying the department and obtaining its approval.

[1975 c.652 810]

522.170 [1971 c.776 \$5; repealed by 1975 c.552 \$55]

522175 Abandonment; proceedings against operator for unlawful abandonment (1) No person shall abandon a geother$\mathrm{mal}$ well without first obtaining approval of the department.

(2) A geothermal well shall be considered lawfully abandoned when the operator has conformed to ORS 522.245 and to rules adopted by the board designed to:

(a) Protect underground and surface water usable for beneficial purposes from pollution resulting from infiltration or addition of any deleterious substance;

(b) Prevent the escape of all fluids to the surface;

(c) Close the surface aperture of the well; and

(d) Remove all surface equipment ex̃cept that necessary to maintain permanent closure of the well.

(3) When the operator has violated subsection (1) or (2) of this section or ORS 522.225 , or when the department has issued a written disapproval of abandonment, the boand may proceed againist the operator and his surety as provided for in ORS 522.145 or 522.185 , and may bring suit pursuant to ORS 522.810 .

[1975 c.552 \$11]

522180 [1971 c.776 \$19; repealed by 1975 c.552 \$55]

522.185 Production and abandonment bond; cancellation; completed well. (1) Upon completing a geothermal well, as described by subsection (3) of this section, the operator of the well shall file with the department a production and abandonment bond in addition to the bond required by ORS 552.145, to insure compliance with the requirements of this chapter and rules adopted and orders issued pursuant thereto, and the sealing of the well when production has ceased. The board by rule shall establish the sum and terms of the production and abandonment bond required.

(2) The production and abandonment bond shall not be terminated and canceled by the board until the geothermal well described by the bond has oeased production and is lawfully abandoned, or another valid bond for the well has been submitted and approved by the boand. 
(3) A geothermal well is completed for purposes of subsection (1) of this section when it is producing geothermal resources and the operator of the well has received written assurance from the department that the manner of drilling of the well and the manner of producing geothermal resources therefrom are satisfactory.

[1975 c.552 813]

522.190 [1971 c.776 \$20, repealed by 1975 c.552 \$55]

522195 Monthy production statement. Except as excluded by rule adopted by the boand, the operator of any completed geothermal well shall file with the department a monthly statement of the geothermal resources production from such well during the preceding calendar month.

[1975 c.552.814]

522200 [1971 c.776 \$28; repealed by 1975 c.552 \$55]

522.205 Transfer or purchase of well; notice; application; fee; notice by landowner of transfer or purchase. (1) Except as excluded from the provisions of this section by rule of the boand, any prospective operator of a geothermal well shall notify the department in such form as the department may direct of the purchase, assignment, transfer, conveyance or exchange of such well within 15 days of the purchase and shall accompany such notice with an application for transfer of the permit for the particular well. The fee for transfer of a permit is $\$ 25$.

(2) Any buyer of land on which a geothermal well is located shall notify the department of the purchase, assignment, transfer, conveyance or exchange of the land upon which such well is situated within 15 days of such purchase.

[1975 c.552 \$15]

522210 [1971 c. $776 \$ 31$; repealed by 1975 c.552 \$55]

522.215 Suspension of drilling or operation; application; terms; extension; presumption of abandonment; unlawful abandonment; notice; proceedings against operator. (1) No operator shall suspend drilling or operation of a geothermal well without obtaining permission from the department.

(2) The department may authorize an operator to suspend for a specific period operations or remove equipment from an uncompleted geothermal well upon such terms as the department may specify, upon written application of the operator and his affidavit showing good cause therefor.
(3) Within a period of six months from the ending date specified for such suspension, the operator may make written application for an extension of suspension, and file it with his affidavit showing good cause for such an extension. Upon a finding that the extension is merited, the board may extend the suspension for an additional specific period.

(4) If, after suspension, operations are not resumed by the operator within six months from the ending date specified for the suspension or extension thereof, an intention to abandon and unlawful abandonment shall be presumed.

(5) Whenever an operator whose operations have been suspended fails to comply with such terms as the department may specify in its authorization, the geothermal well shall be presumed unlawfully abandoned. A well shall also be deemed unlawfully abandoned, if, without notice to the department, any drilling or producing equipment is re moved.

(6) An unlawful abandonment shall be declared by order of the boand, and written notice thereof shall be mailed by registered mail both to such operator at his last-known post-office address, to his registered agent if any, and to the operator's sureties.

(7) After declaration of unlawful abandonment, the boand may proceed against the operator and his surety as provided for in ORS 522.145 or 522.185, and may bring suit pursuant to ORS 522.810 .

[1975 c.552 \&16]

522.220 [1971 c.776 \$21; repealed by 1975 c.552 \$55]

522.225 Notice of intent to abandon. (1) Before commencing any operation to abandon a geothermal well, the operator shall give notice to the department of his intention to abandon the well and the date upon which the work of abandonment will begin.

(2) Such notice shall be given at least 24 hours before the commencement of abandonment operations and shall indicate:

(a) The condition of the well;

(b) The proposed method of the abandonment operation; and

(c) Any additional information that may be required by the department.

[1975 c.552\$17]

522230 [1971 c.776 \$23; repealad by 1975 c.552 \$55]

522235 Conditions precedent to abandonment. Before the proposed date upon which the work of abandonment will 
begin, the department shall furnish the operator with:

(1) Approval to commence the abandonment operation;

(2) Conditional approval to commence the abandonment operation, stating what specific work or tests will be necessary before approval of the abandonment operation will be given; or

(3) A report stating what specific information is required to be furnished by the operator to the department before the department may take action upon the proposed abandonment operation.

[1975 c.552 (18]

522240 [1971 c.776 69; repealed by 1975 c.552 555]

522.245 Department approval of abandonment; report by operator, effect of failure to comply; proceedings against operator. (1) A representative of the department shall be present during any abandonment operation. If he determines that the abandonment is satisfactory, he shall approve the abandonment of the well.

(2) Within 30 days after the completion of abandonment of any geothermal well, the operator of the well shall make a written report of all work done with respect to the abandonment. Within 10 days after the receipt of such report, the department shall furnish the operator with a written final approval of abandonment, or a written disapproval of abandonment setting forth the conditions upon which the disapproval is based.

(3) Failure to abandon in accondance with the approved method of abandonment, failure to submit to the department any notice or report required by this chapter, or failure to furnish the department with any required information shall constitute sufficient grounds for disapproval of the abandonment of such well.

(4) When the department has issued a written disapproval of abandonment, the board may proceed against the operator and his surety as provided for in ORS 522.145 or 522.185 , or may bring suit pursuant to ORS 522.810 .

[1975 e $552 \$ 19]$

522250 [197] c.776 \$10; ripraled by 1975 c.552 \$55]

520.30 [1971 c.776 \$30; nppalud by 1975 c.552 \$55]

\section{ADMINISTRATION}

522.275 Administration by State Geol. ogist. Subject to policy direction by the board, the State Geologist shall administer this chapter, the rules and orders made pursuant thereto, and supervise the department in carrying out the provisions of this chapter. [1975 c.552 823]

522.305 Rules. In accordance with applicable provisions of ORS chapter 183, the board may make reasonable rules necessary for the administration of this chapter.

[1975 c.552 \$22]

622310 [1971 c.776 824; repealed by 1975 c.552 855]

522315 Final order of department; delivery to operator. Whenever the department gives any written direction concerning any geothermal well and the operator requests in writing that a final order for purposes of ORS chapter 183 be made, the department shall, within 15 days after receipt of the notice, deliver such final written order to the operator.

[1975 c.552 \$24] \$55]

522320 [7971 c.776 \$825, 26; repealed by 1975 c.552

522325 Compliance with final order; appeal (1) The operator of any geothermal well shall within 15 days from the date of the service of any order, either comply with the order or file with the department a written statement that the order is not acceptable, and the reasons therefor, and the statement shall constitute an appeal from such order to the board.

(2) Any final written order of the board may be appealed in the manner provided in ORS chapter 183 for appeals from final orders in contested cases.

[1975 c.552 \$25]

522330 [ 1971 c.776 \$27; repealed by 1975 c.552 \$55]

\section{WELL RECORDS}

522.355 Records of well; contents; drill cutting and core samples. (1) The operator of any geothermal well shall keep, or cause to be kept, a careful and accurate log, core record and history of the drilling of the well.

(2) The log referred to in subsection (1) of this section shall show the character and depth of each formation encountered in the drilling of the well; the amount, size and weight of casing used; and the location, depth 
and temperature of water-bearing strata, including the temperature, chemical composition and other chemical and physical characteristics of fluid encountered from time to time, so far as determined.

(3) The core recond referred to in subsection (1) of this section shall show the depth, character and fluid content of cores obtained, so far as determined from the study and analysis thereof.

(4) The history referred to in subsection (1) of this section shall show the location and amount of sidetracked casings, tools or other material; the depth and quantity of cement in cement plugs, the shots of dymamite or other explosives used; the results of production and other tests during drilling operations; and completion data.

(5) The log referred to in subsections (1) and (2) of this section shall be kept in the local office of the operator and, together with the tour reports of the operator, shall be subject, during business hours, to inspection by the board, or department.

(6) The operator of any geothermal well shall, in addition to furnishing the log, reconds, and tests required by this section, collect representative drill cuttings. The operator shall additionally, in the event cores are taken, collect representative core samples. The drill cuttings and core samples shall be filed with the department promptly upon completion or upon its written request, and upon the abandonment or upon suspension of operations for a period of at least six months. [1975 c.552 \$26; 1977 c.87 \$4]

522.365 Filing record with department; exemption from disclosure. (1) Each operator of any geothermal well or his designated agent shall file with the department a copy of the log, history and core record, or any portion thereof, promptly upon completion, or upon the written request of the department at any time after the commencement of the work of drilling any geothermal well, and upon the abandonment or upon suspension of operations for a period of at least six months.

(2) For a period of four years after the receipt of any log, history, core record, or any portion thereof, such record shall be exempt from disclosure as a trade secret pursuant to subsection (1) of ORS 192.500 unless the operator gives approval to release the data. [1975 c.552 \$27]1

522410 [1971 c.776 \$3; repealed by 1975 c.552 \$55]

522.420 [ 1971 c.776 \$35; repealed by 1975 c.552 \$55)
620.430 [1971 c.776 536; repealed by 1973 c.388 88]

622440 [1971 c.776 838; repealed by 1973 c.388 88]

622450 [1971 c.776 \$37; repealed by 1973 c.388 88]

522.460 [1971 c.776 84; repealed by 1975 c.552 655]

622.470 [1971 c.776 \$22; 1973 c.388 \$5; repealed by 1975 c.552 855]

522.480 [1971 c.776 \$33; 1973 c.388 \$6; repealed by 1975 c.552 855]

622.510 [1971 c776 \$15; 1973 c.794 \$24; repealed by 1975 c.552 855]

522520 [1971 c.776 \$17; 1973 c.794 \$25; repealed by 1975 C 552855$]$

522530 [1971 c776 \$16; repealed by 1973 c.794 \$34]

522.540 [1971 c.776 \$29; repealed by 1973 c.794 834]

\section{ENFORCEMENT}

522.810 Suits to enjoin violations. Whenever it appears that any person is violating or threatening to violate any provision of this chapter or any rule or order of the board made thereunder, or is threatening to or committing waste, the board may bring suit against such person in the circuit court of any county where the violation or waste cocurs or is threatened, to restrain such person from continuing such violation or waste. In any such suit, the court shall have jurisdiction to grant to the boand, without bond or other undertaking, such temporary restraining orders or final prohibitory and mandatory injunctions as the facts may warrant, including any such orders restraining the movement, disposition or waste of geothermal resources.

[1971 c.776 \$41; 1973 c.388 \$7; 1975 c.552 \$29]

522.815 Orders by board; scope; notice; hearing. (1) When necessary to conserve geothermal resounces or other natural resources, or to protect the environment, the correlative rights of any person having an ownership interest in the affected land or resource, or beneficial uses of water, or to acomplish the efficient and economical development of a geothermal reservoir, the board may, upon the request of any interested party or upon its own motion, after hearing, enter an onder. The order shall include a description of the geothermal reservoir and the overlying land and may also include provisions for the following:

(a) Division of a geothermal reservoir into zones; 
(b) Establishment of spacing units including a description of the location, size and shape of such spacing units;

(c) The integration of separately owned tracts or interests within a spacing unit for the development and operation of the spacing unit and the sharing of production therefrom;

(d) Unit operation of one or more reservoirs within a field and a statement of the terms, conditions and procedures for such unit operation including the allocation of production, royalties and costs. Such allocation shall be in accondance with any agreement of the parties, or if there is no such agreement, then such allocation shall be fair, just and equitable;

(e) The protection of existing and future beneficial uses of water,

(f) Maintaining the renewability of geo thermal resources and any other natural resources; and

(g) Any additional provisions the boand deems necessary for carrying out the provisions of chapter 552, Oregon Laws 1975 or for protecting the public health, safety and welfare.

(2) Any order entered under this section may in the board's discretion supersede any right or privilege previously granted by or previously entered by the boand with respect to such reservoir and may after hearing be amended or supplemented as appears necessary to the boand to accomplish the purposes of chapter 552, Oregon Laws 1975.

(3) Any proceeding under this section shall be conducted as a contested case in accordance with ORS chapter 183. In addition to the notice requirements of that chapter, notice shall be given to the following persons:

(a) Any operator who has a drilling permit issued pursuant to ORS 522.135 or has a legal right to operate a geothermal well pursuant to ORS 522.185 in the geothermal reservoir;

(b) Any person who has an ownership interest in the geothermal reservoiri and

(c) Any person who has an ownership interest in land within one mile of the boundaries of the geothermal reservoir.

[1975 c.552 \$4.3]
Note: The Legislative Counsel has not, pursuant to 173.160, undertaken to mubstiturte specific ORS references for the words "this Act" in 522.815. Chapter 552, Oregon Laws 1975, enacted into law and amended the ORS sections which may be found by referring to the 1975 Comparative Section Table located following the Index in volume 6 of Oregon Revised Statutes (1975 Replacement Parts).

\section{PROHIBITED ACTS}

522.910 Aiding in violations prohibited. No person shall knowingly aid or abet any other person in the violation of any provision of this chapter or of any rule or order of the board made thereunder.

[1971 c 776 840; 1975 c.552 830]

522.915 False entries, omissions, destruction, or removal of records or reports. No person shall:

(1) Make or cause to be made any false entry or statement in a report, recond, $\log$, account or 'other writing required by this chapter or any rule adopted pursuant thereto;

(2) Omit or cause to be omitted from any such report, recard, $\log _{\text {, }}$ account or uriting, full, true and carrect entries as required by this chapter or any rule or onder adopted pursuant thereto;

(3) Destroy, mutilate, alter or falsify any such report, record, log, account or writing; or

(4) Remove from this state the original copy of any such report, record, log, account or writing before an abandonment has been approved pursuant to subsection (2) of ORS 522.245.

[1975 c.552 828]

522.920 [1971 c.776 \$39; repealed by 1975 c.552 \$55]

\section{PENALTIES}

522.990 Penalties. Violation of any provision of this chapter or of any rule or order of the board made thereunder is punishable, upan conviction, by a fine of not more than $\$ 2,500$ or by imprisonment in the county jail for not more than six months, or both. [1971 c.776 \$42; 1975 c.552 \$31] 
Pursuant to ORS 173.170, I, Thomas C. Cliffond, Legislative Counsel, do hereby certify that I have compared each ection printed in this chapter with the original section in the enrolled bill, and that the sections in this chapter are correct copies of the enrolled sections, with the exception of the changes in form peranitted by ORS 173.160 and other changes epecifically authorized by law.

Done at Salem, Oregon,

October 1, 1977.

Thomes G. Clifford

Legislative Counsel 



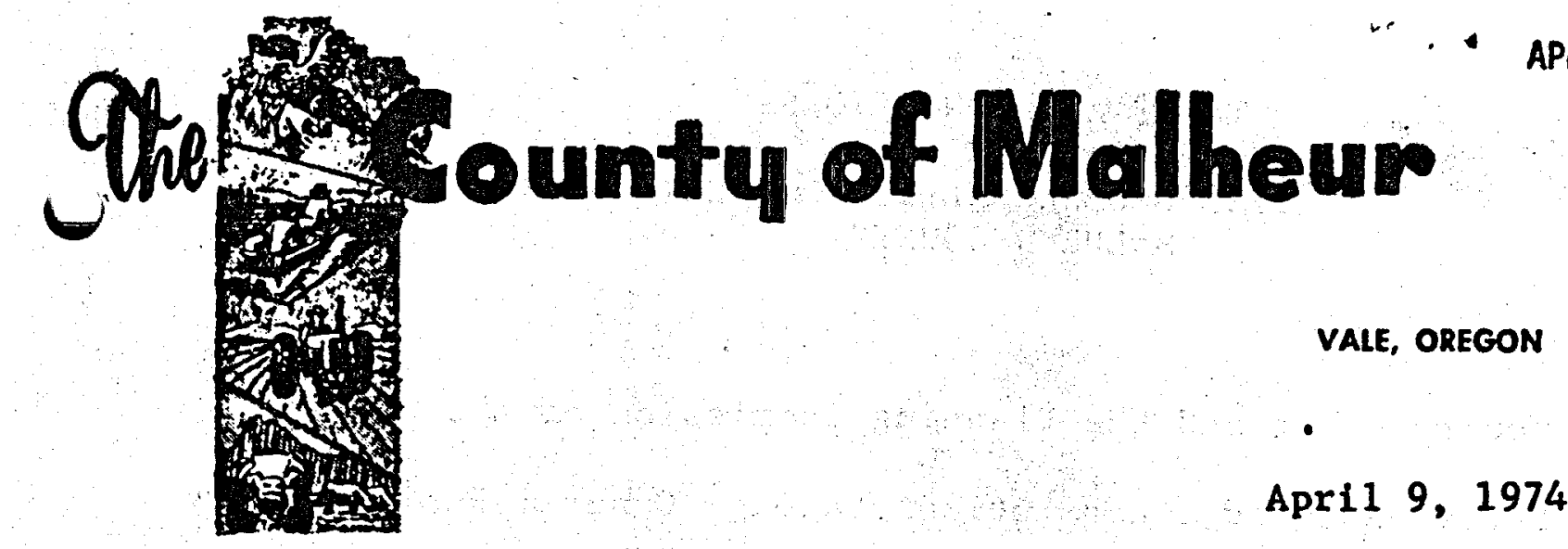

RESOLUTION ADOPTING A GEOTHERMAL ORDINANCE FOR THE COUNTY OF MALHEUR AND PROVIDING FOR THE ISSUANCE OF PERMITS, COLLECTION OF FEES, PROVIDING PENALTIES FOR THE VIOLATION THEREOF :

WHEREAS, Malheur County has adopted and is enforcing a zoning ordinance, and

WHEREAS, the planned building permit prohibits any person, firm or corporation from erecting, constructing, enlarging, altering, repairing, improving, moving or demolishing any building or structure without first obtaining a separate building permit for each building or structure from the County Planner, and

WHEREAS, the Planning Commission must examine all plans and specifications for the proposed construction when application is made to them for a permit or permits.

THE' COUNTY COURT OF THE COUNTY OF MALHEUR, OREGON, DOES ORDAIN AS FOLLOWS:

Terms, Conditions, Standards, and Application Procedures for Initial Geothermal Development, Malheur County, Oregon; hereafter known as the Geothermal Ordinance, as follows.

Prepared by the Planning Commission and Planning Department, Malheur County 


\section{TERMS AND CONDITIONS \\ FOR \\ INITIAL GEOTHERMAL DEVEIOPMENT \\ MAJ.HEUR COUNTY}

1. PREAMBLE

The County Court and the Planning Commission of the County of Nalheur have adopted a Resolution stating General Public Policy surrounding the initiation of Geothermal Development within this County. This policy is interim in nature in that it calls for the development of a General Plan for the total development of the Geothermal Resucurce within the County. In addition, this Policy provides for the initiation of Geothermal Development by allowing various agencies, both public and private, to commence their own ititial development projects.

It is the intent of this policy to encourage exploration and development projects and to increase the store of knowledge surrounding this resource. It is also the intent of this polfcy that there be coordination of existing and anticipated data so that the end result may be General Planning that will provide for the optimum development of the available resource.

Im many areas of the State, the Geothermal Resources are under study and in one area is already producing energy for he ating. Current explorations in most arcas are pointed chiefly at the energy field and property so as there is much need for a clean source of energy for the development of electrical power. However, it must not be nverlocked that there is a possibility for a new source of 
potable water and mineral recovery. Additional research is needed in all fields if this Geothermal Resource is to be developed to its ultimate.

The early studies show that much of the Geothermal Resource In this area lies below the floor of the Malheur and Willow Creek Valley. This Valley is a major agricultural area and its preservation is necessary for the continued economy of the County and to provide food and fibre for the populace.

The University of Oregon and other State Agencies; several Federal Agencles, most prominently the Department of the Interfor; and Industry are all involved in research and study programs surrounding the development of this Geothermal Resource. Many industries have stated their desire to continue to explore and begin production of the resource.

It is recognized that a General Plan providing for total development of the resource is needed but that it cannot be a Comprehensive General Plan without the input of additional research and data.

It is therfore the intent of this policy to allow for the complete development of a series of initial projects in addition to exploratory well drilling and testing. To accomplish this, following in Paragraph III are a series of terms and conditions designed; (1) to allow these initial developments; (2) to provide for the optimum use of the land; (3) to protect the environment; and (4) to provide for cooperation in the development of a Com- 
prehensive General Plan for Geothermal Development.

II . POLICY

BE IT RESOLVED, that a general plan shall be prepared to designate where, and under what conditions, geothermal production wells, power plants, and attendant uses may be located in Malheur Cornty;

BE IT FURTHER RESOLVED, that pending preparation of the general plan, the County shall:

(1) Authorize the establishment of geothermal production projects in designated locations and under prescribed terms and conditions;

(2) Authorize the drilling of exploratory geothermal wells and the use of resources produced therefrom for testing purposes, in various 1 and use zones;

(3) Advocate the adoption of legislation designed to insure the orderly development of geothermal resources and to protect the public interest. 


\section{TERMS AND CONDITIONS}

\section{A. DEFINTTIONS}

1. "Operator" means any person, firm, or corporation drilling, maintaining, operating, pumping, or in control of any well or related facilities for power generation, mineral extraction, desalination or any other use of geothermal resources.

2. "Geothermal Production Project" Includes the right to explore for, test, produce, process, transport and sell geothermal resources and by-products such as electrical power, desalinated water, minerals and heat from within the " $G$ "' Zone area designated by the Planning Comission.

3. "Exploratory Geothermal We1l" Includes the right to explore for the test geothermal resources within an area designated by the Planning Commission.

4. "Test" means to produce geothermal fluids and/or steam for a length of time, at a volume and rate accepted by the County and Re'gional Water Quality Control Board.

5. "Test Facilities" means Iines, pumps, separators, metering facilities, ponds and sumps used during the testing of a geothermal well or injection well.

6. "Permit for Geothermal Exploratory Well", is a Conditional Use Permit allowable In various zones within the County.

7. "Permit for Geothermal Development Project" is a Conditional Use Permit to produce Geothermal Well or Wells in a "F-1"or"F-2"or"G"zoned area. 


\section{8. "G-zone", Geothermal Development Zone in a land}

classification zone overlay permitting additional uses within other zones including Geothermal Well operation (after obtaining a Conditional Use Permit).

\section{B. GENERAL CONDITIONS}

1. Proposal - A definite detailed proposal for a Geothermal Development Project shall be submitted in accordance with the procedures and standards. This proposal shall include geologic and engineering evidence that gives reasonable assurance of success.

\section{Application Reservation - The Planning Commission}

reserves the right to deny an application if it will not be compatable with the area or that, in 1t's findings, that some of the terms and conditions are not met satisfactorily.

\section{Procedures and Standards - All applicants will be} required to comply with Governmental procedures and standards applicable to the particular phase of work.

4. Compliance with the Law - The operator engaged in the drilling, production maintenance and abandonment of Geothermal Wells and related facilities including the disposal of waste products shall comply with all applicable local, state, and Federal laws and ordinances in effect or subsequently duly enacted.

5. Commencement of Work - Prior to commencing any operation all Governmental conditions and standards applicable to the particular phase of work contemplated shall be complied with. 
6. General Compliance - All well drilling, plant construction, testing and operations shall be conducted so as to be in harmony with the area and do not conflict with the public health, safety, comfort, convenfence and general welfare.

7. General Plan Development - The operator shall cooperate with the County or the County's agent in the development of the County's Geothermal Element for the General Plan. The operator will be expected to provide data and knowledge up to, but not in-. cluding "proprietary information".

8. Permit Expiration - All permits (for exploratory we 11s and for development projects) shall contain terms and conditions. Abandonment of a project for six (6) months shall cause the permit then in effect to expire and to become null and void.

9. Timetable - A reasonable timetable for project development will be made a condition of any permits granted.

10. Bonds - Each operator of a "Geothermal Production Project" and/or "Exploratory Geothermal We11" shall file and fur$n$ sh with the County an indemnity bond in the sum of $\$ 50,000.00$ for each we 11 drilled or abandoned we 11 re-entered or a blanket bond in the siln of $\$ 150,000.00$ for any number of wells drilled or reentered. The Bond will indemnify the County for any costs incurred by the County in repairing any drill, test, or production facility site, to as near as possible to its original state and in abating any public nuisance caused by the principal's exploratory, testing or producing operations. 
11. Insurance - Before commencing or continuing any.

Geothermal operations, the owner ne operator shall show continuing., evidence of insurance against liability in tort in a minimum amount of $\$ 1,000,000.00$ arising from the production activities or operations incidental thereto conducted or carried on under, or by virtue of any law or ordinance. Such insurance shall be kept in full force anc effect during the period of such operations.

12. Subsidence - Any operator of a Geothermal Production Project shall participate in a Geothermal subsidence prevention and detection program developed by the County, state, and Federal Government.

13. Cleanup - Upon completion of any phase of the project, the site shall be cleaned up in accordance with the Standards, and insofar as practical, the land returned to its original condition.

14. Waste Disposal - All waste, whether liquid or solid, must be disposed of in compliance with the existing County, State, and Federal rules and regulations.

15. Noise and Vibration Supression - The operation of temporary or permanent equipment and all other operation performed on the premises shall be done in a manner so as to suppress all noise and vibration to an acceptable level.

15. Electronic Interference - No operator sha1l operate electrical equipment or transmissjon faciljties that will have a detrimental effect on the transmission of radio or television signals 17. Air Pollution - All operations shall be conducted 
in compliance with the requirements of the Oregon Department of Environmental Quality.

18. Aesthetic Requirements - All permanent installation

and premises including power, steam and/or fluid transmission lines, shall be harmonious in appearance with the area and not of obnoxious, undesirable or unsightly appearance.

19. Land Use - Site development plan and land use shall provide for maximum surface land usage including preservation of productive farm land and shall be in accordance with the standards. 20. Odor and Gas Control - All operators shall take steps to insure that no harmful or obnoxious gases be released as a result of their operations.

21. Right of Entry - The County reserves the right to enter the premises under the control of the operator of any Geothermal operation to make appropriate inspections to determine if the conditions of this policy are being fulfilled.

22. Public Facilities - If location or site of the proposed project is such as to require additional public access facilities, the operator shall be required to provide where necessary, rights of wav on property he controls and to provide the necessary road work. 23. Operation Personne 1 - All development operations shall be conducted under the direction of a responsible engineer or agent. The operator shall insure that a maintenance crew is immediately available to insure compliance with the conditions and standards required. 


\section{Scope of Terms and Conditions - The terms and conditions}

rescribed shall be for a particular project and will pertain to hat project only. Future projects may rekeive additional and/or ifferent terms and conditions. 


\section{APPLICATION PROCEDURES}

\section{PROCEDURES}

\section{A. Exploratory Geothermal Wel1, To obtain an "Exploratory}

Geothermal Well" permit, an operator must submit a conditional use permit application for a geothermal exploratory well. In addition," the operator must submit to the Planning Commission for their approval, a definite proposal for the work to be done, including, but not limited to:

1. Name, location, and elevation of the well to be drilled;

2. Home, address, and telephone number of operator's designated agent;

3. A surface plat of the property to be explored including: a. surface location sites of the proposed well, including the size and shape of location and access roads;

b. north arrow, scale, date, and contours of land where the grade exceeds two percent;

c. the boundary of the parcel to be explored;

d. the locations of existing roads, water ways, and cultural features including the present use of the property to be developed, and use of the surrounding property;

e. the location of test facilities including complete engineering data concerning any holding pond or reservoir proposed in conjunction with testing and 


\section{waste discharge requilrements.}

f. the location of existing roads, water ways and cultural features.

4. Proof that the well program has been approved by the State Division of 011 and Gas, and that all test and waste discharge operations have been filed with the Oregon State Department of Environmental Quality.

3. Geothermal Production Project. To obtain a "Geothermal Production Project: permit, an operator must submit:

1. a rezoning application for the " $G$ "' zone if necessary;

2. a conditional use permit application for a geothermal exploratory well or copy of existing permit.

3. a conditional use permlt application for a geothermal production project.

As a part of the application the operator must submit to the Planning Commission for their approval, a definite proposal for total development which includes the following data but is not limited to:

1. Name, location elevation of well or wells to be drilled 2. Name, address, and telephone number of the operator's designated agent;

3. A surface plat of the property to be developed includini a. surface location sites of proposed weils, includini size and shape of drilling locations and access roads; b. north arrow, scale, date and contours of $l$ and where the grade exceed two percent; 
c. the locations of existing roads, water ways, and cultural features, including the present use of the property to be developed, and the use of the surrounding property;

d. the boundary of the parcel to be developed;

e. the location of test facilities including complete englneering data concerning any holding pond or reservolr proposed in connection with testing and waste discharge requirements;

f. a tentative plan showing the size and location. of power generation, mineral extraction, desalination and other surface factlities including their relatinnship to known active faults.

4. A general geologic and engineering presentation showing enough data to demonstrate that the area contains geotherma 1 resources.

5. A timetable showing a schedule of projected development. 6. Proof that the program for well or wells, has been approved by the State Division of 011 and Gas and that all test and waste discharge operations have been filed with the Oregon Department of Environmental Quality. 7. Submit for approval any additional anticipated land use needs such as extra facilities and proposed sites for new industry.

C. Genera 1 Procedures.

1. Upon receipt of applications and the required 
secondary information, the County Planning Department will set a Public Hearing for the Planning Commission, notify appropriate property owners, agencies and individuals of said hearing. Planning Commission will consider testimny of all interested parties and then take appropriate action on the various applications.

2. The Planning Commission has a scheduled meeting for the 4th Thursday of each month. In order for an application to be heard, it, along with all zoning information, must be filed at least two weeks prior to the meeting.

II STANDARDS

A. Classification of Standards

1. Class I Standards:

a. Class I Standards shall apply to any exploratory Geothermal Well, or Geothermal Production Site in Malheur County.

2. Class II Standards:

a. Class II Standards shall apply in addition to the Class I Standards, to any Exploratory Geothermal Well or Geothermal Production Sịte adjacent or neaf existing development as determined by the Planning Commission.

B. Planning Standards.

1. Class I Planning Standards:

a. Al1 Geothermal Drilling sites including test 
factlities and ponds shall be as small as possible and in no case larger than five acres on arable land. Exceptions will be allowed if two or more wells are drilled from the same site.

b. Every site shall be designed to retain the maximum amount of usable agricultural land and the site shall not interfere with the irrigation and drainage pattern. Drill sites shall be constructed adjacent to existing roads insofar as possible. Well density shall be justified and in accordance with good Reservoir Engineering Practices.

c. Unless specifically walved by the Planning Commission where legally permissible, the following minumum distances shall be observed in sitting a well:

$\begin{array}{lr}\text { Outer Boundary of Parcel } & 100^{\prime} \\ \text { Permanent Public Waterway } & 50^{\prime} \\ \text { Public Roads } & 100^{\prime} \\ \text { Residence } & 300^{\prime} \\ \text { School } & 1320^{\prime} \\ \text { Hospital } & 5280^{\prime} \\ \text { Any other development } & 500^{\prime}\end{array}$

d. Production Facilities shall where possible, be located in centralized areas to serve the maximum number of wells. These shall include but are not limited to power plants, extraction plants, and 
separators.

e. All electrical transmisston lines shall be constructed on existing right of way whenever possible.

f. The plans for all permanent sumps, brine ponds, waste holding ponds, and any other ponds, shall include a soils investigation and shall be designed and constructed under the supervision of a registered Civil Engineer. The following are considered minimur. criteria:

(1) Pond bottoms and dykes shall be either impervinu or shall be 1 ined to prevent seepage;

(2) Earthen dykes shall have 3:1 slopes;

(3) Dykes shall be designed to provide three feet free board when at design capacity;

(4) Plan should minimize wave and wind erosion;

(5) Protect from any flood hazard.

The plans shall be submitted to the County for approy g. A reproducible copy of the plot plan shall be submitted on suitable material. It shall be $18^{\prime \prime} \mathrm{X}$ 26 " with an appropriate scale and shall be prepared in accordance with good engineering and drafting techniques. It sladl show all existing topography an facilities and shall clearly show proposed developmen 
C. Drilling Standards

1. Class I Drilling Standards:

a. All Geothermal Well sites shall have a sign having a surface of not less than two square feet and not more than six square feet bearing the current name and number of the we11; emergency telephone number of agent; name and/or insignia of the operator and the owner and this sign shall be displayed at all times from the commencement of drilling operations until the well has been abandoned. b. Each operator shall limit the continuous generation of wide band noise to that shown on the chart. The level shown may be exceeded by ten percent (10\%) if the noise is intermittent and during daylight hours. The noise levels shall be measured at the parcel boundary.

- c. Sound pressure levels shall be measured at the points specified and shall be measured with a sound level meter and associated octave band analyzer conforming to standards prescribed by the United States of America Standards Institute.

\section{(chart on next page)}




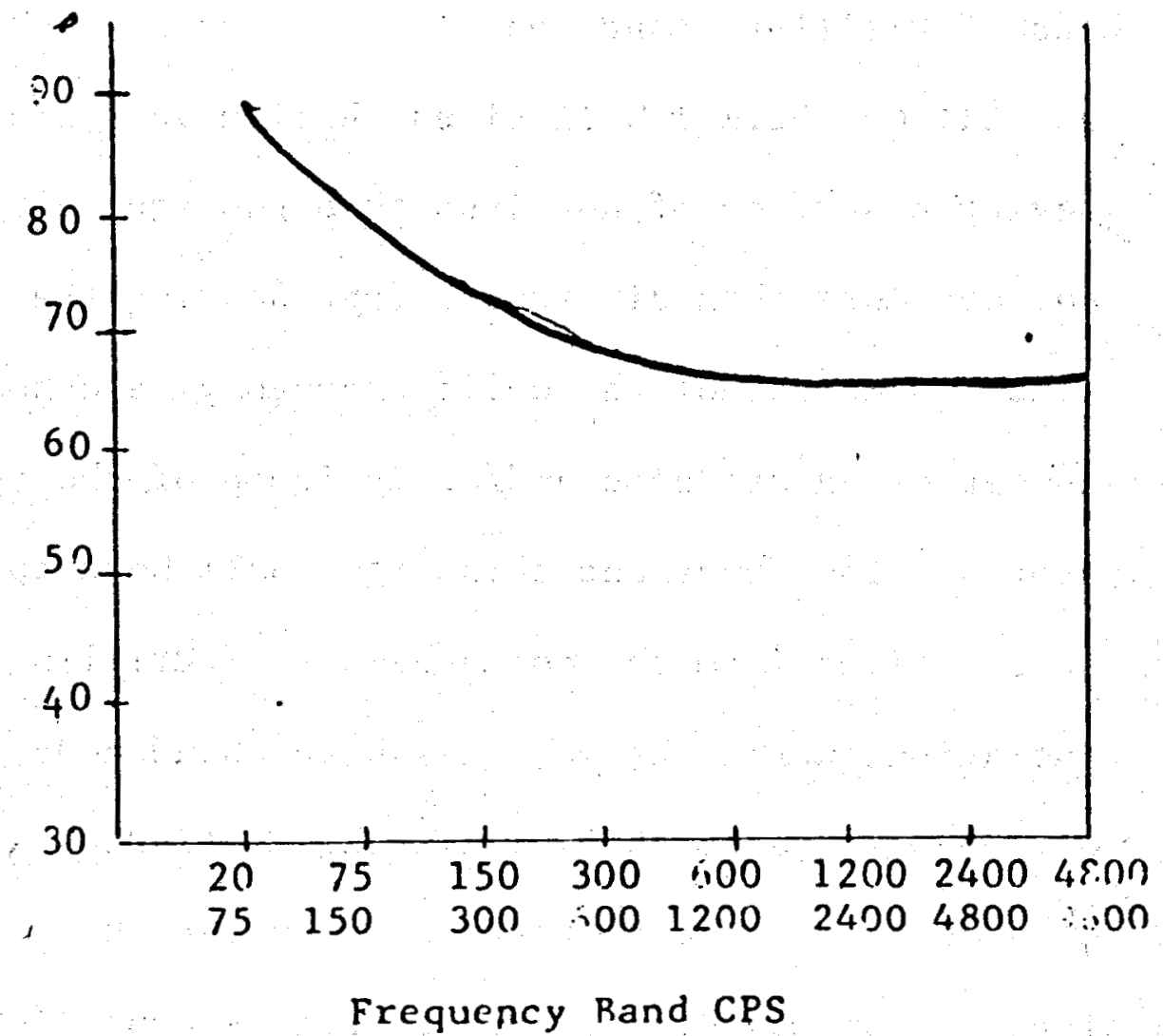

d. The foregoing graph shall conform to standard units of meas"rement in accordance with United States cf America Standards Institute Code, S-1.11-1955, Appendix A .

$\therefore$ Within sixty (60) days after the coirpletion of the drilling of a well, all drilling wastes must be removed from the drilling site and disposed of, in accordance with County and State regulstions. f. Sulable and adequate sanitary factlities as approved by the Malheur County Health Departinent shal be installed and maintained in a clean and sanitary condition a: a!l tines . 
g. Drilling operations shall be diligently pursued until each well is completed or abandoned. A11 drilling equipment including derrick shall be removed from the premises within sixty $(60)$ days after completion of any well.

h. Prior to abandonment it shall be the responsibility of the operator to comply with all regulations of the Geothermal Resources Law of the State of Oregon in regards to subsurface actions. In addition, the following surface requirements are imposed. These surface requirements shall also apply when the well or wells goes on production and auxiliary facilities are no longer necessary.

(1) The derrick and all appurtenant equipment thereto shall be removed;

(2) All tank, towers, other surface installations shall be removed;

(3) All concrete, pipe, wood, or other foreign materials shall be removed from the drill site to a depth of six feet below grade;

(4) All holes and depressions shall be filled and packed with native earth. All waste material shall be removed from the drill site.

(5) In agriculture or potential agriculture areas any brine holding ponds shall be purged of brine, the salts shall te removed from the dyke and 
bottom and the berms leveled to the satisfaction of the County.

2. Class II Drilling Standards:

a. All work in preparation of the site for drilling shall be done between the hours of $7 \mathrm{a} . \mathrm{m}$. and $7 \mathrm{p.m}$. b. All unattended well sites shall be enclosed by a steel chain link type fence, six (6) feet high. There shall be no opening below such fence greater than four (4) inches. The gate shall be placed at a non-hazardous location and shall be locked at all times.

c. The Planning Commission shall direct which Noise Lèvel curve as shown on the chart shall apply. Each operator shall limit the continuous generation of wide band noise to that required. The level may be exceeded to ten percent $(10 \%)$ for any one occurance if the noise is intermittent and during daylight hours.

d. Sound pressure levels shall be measured at the points specified and shall be measured with a sound level meter and associated octave band analyzer conforming to standards prescribed by the United Stated of America Standards Institute. e. The following graph shall conform to standard units of measurement in accordance with United States 
of America Standards Institute Code; S-1.11-1966, Append1x A :

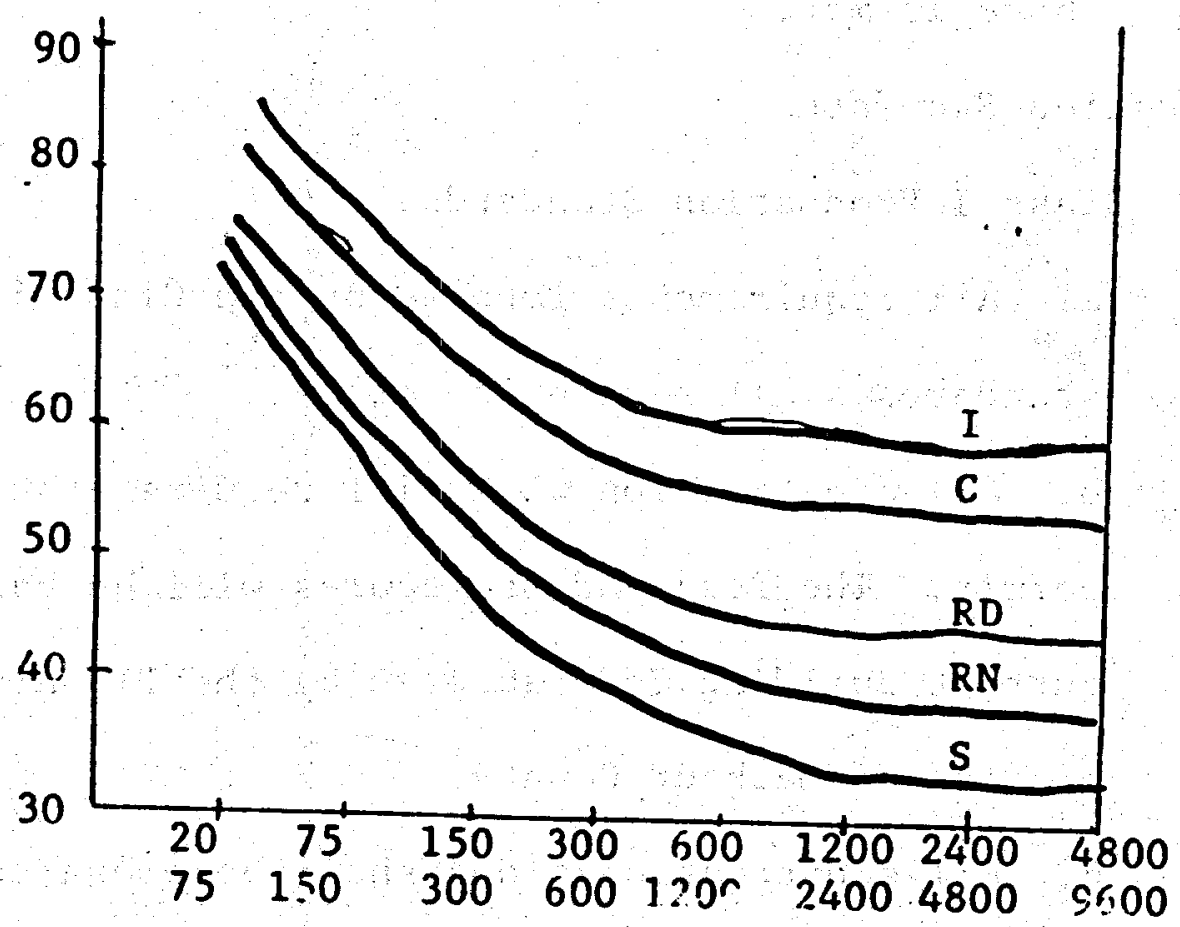

Frequency Band CPS

f. Off street parking sha11 be provided with not less than five spaces for each well site.

g. A11 1 lghts shall be directed or shielded so as $\checkmark$

to confine the direct rays to the site.

h. The delivery or removal of equipment or material shal 1 be 1 imited to the hours from $7 \mathrm{a.m.t} 7 \mathrm{p.m.}$, except in the case of emergency.

i.. lo drill pipe shall ie racked or made up except Detween the hours of $7 \mathrm{a} . \mathrm{m}$. to $7 \mathrm{p.m}$. Exception to this is allowed where sond proofing is provided or in case of emergency.

j. The drij site shall be treated to eliminate 
dust and mud.

- k. Drilling may be on a 24 hour basis providing above is met.

D. Production Standards

1. Class. I Production Standards:

a. All requirements imposed by the Class I drilling standards shall remain in effect.

b. All construction work will require a building permit. The fees and procedures will be based on the current Building Code adopted by the Planning Commission of Malheur County.

c. All construction plans shali be prepared in accordance with the Architectural Design Zone. d. Continuous, and intermittent sound shall be controlled to the levels listed under C 1 (c) (Drilling Noise Standards for Class I)

- e. The operator shall install a minimum of one permanent benchmark per well as directed by the County Surveyor in order to participate in the Subsidence Detection Program. The benchmark shall be constructed of concrete and firmly set. A brass cap as furnished by the County Surveyor shall be placed in the monument. The operator shall tie this benchmark into the nearest point of the U.S.G.S. level net by First order Leveling techniques. 
f. Power lines shall be constructed on existing power right of ways where possible. Efforts shall be made to share existing facilities. Any new power line installations shall conform with County optimum land use and aesthetic requirements:

g. All on site roads and parking areas shall be paved. On site parking shall be provided for all employees, customers, or clients.

h. Shrubs, trees, and ground cover shall be planted and maintained to compliment the appearance of the project where soll conditions permit.

\section{Class II Production Standards}

a. All applicable requirements Imposed by the Class II Drilling Standards shall rematn in effect. b. Continuous and intermittent sound shall be controlled in accordance with paragraph C 2 (c) ' (Drilling Standards Class II)

c. All off site collection pipe lines shall be buried and shall utilize and share existing dedicated right of ways. On site collection pipe lines shall be painted and/or landscaped to blend with the environment. 


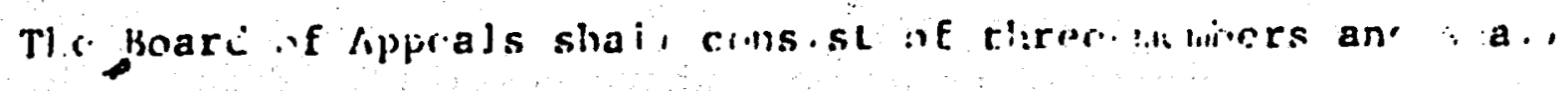
ha: 1 County Cot:rt.

PASSED AHI A.JOPTED by the County Corrt and APPROVED by $\because$ Juge of the Cozinty of Malheur this slay of , 1 : COUNT: JUDGE

\section{COUNTY COMMISSIONER}

COUNTY COMMISSIONER

GECTHERIAL ORDINANCE 


\section{GEOTHERMAL REGULATORY PROCESS}

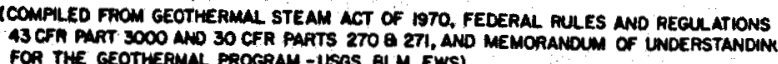

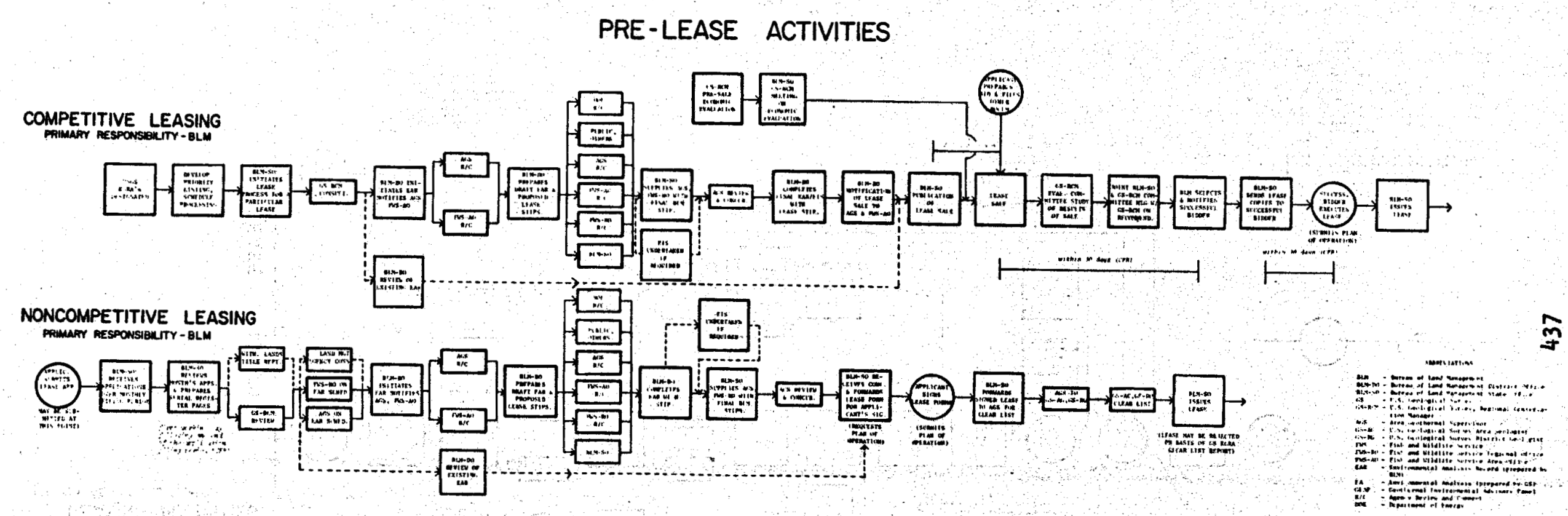


GEOTHERMAL REGULATORY PROCESS

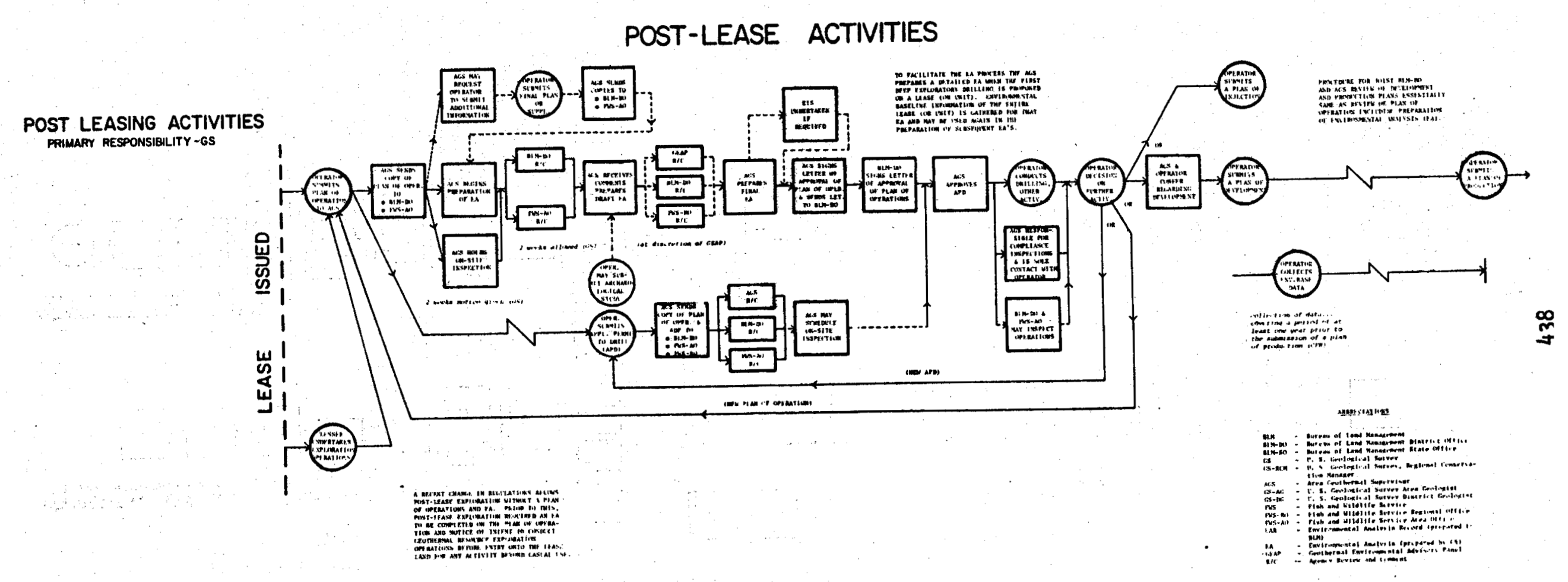

